\title{
DOE/WIPP 03-3295
}

\section{Basic Data Report \\ For Drillhole SNL-12 (C-2954) \\ (Waste Isolation Pilot Plant)}

April 2004

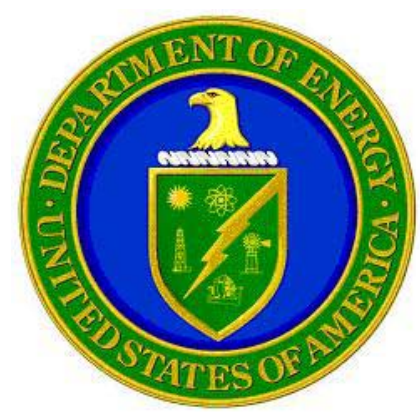


This document has been reproduced directly from the best possible copy. It is available to DOE and DOE contractors from the following address:

Office of Scientific and Technical Information

P.O. Box 62

Oak Ridge, TN 37831

Prices available from (615) 576-8401

Available to the public from the National Technical Information Services United States Department of Commerce 5285 Port Royal Road Springfield, Virginia 22161

Processing and final preparation of this report was performed by the Waste Isolation Pilot Plant Management and Operating Contractor for the U.S. Department of Energy under Contract No. DE-AC29-01AL66444. 
DOE/WIPP 03-3295

\title{
Basic Data Report \\ For Drillhole SNL-12 (C-2954) \\ (Waste Isolation Pilot Plant - WIPP)
}

\author{
Dennis W. Powers \\ Consulting Geologist \\ 140 Hemley Road \\ Anthony, TX 79821 \\ and \\ Ronald G. Richardson \\ Washington Regulatory and Environmental Services \\ P.O. Box 2078 \\ Carlsbad, NM 88220
}

April 2004 


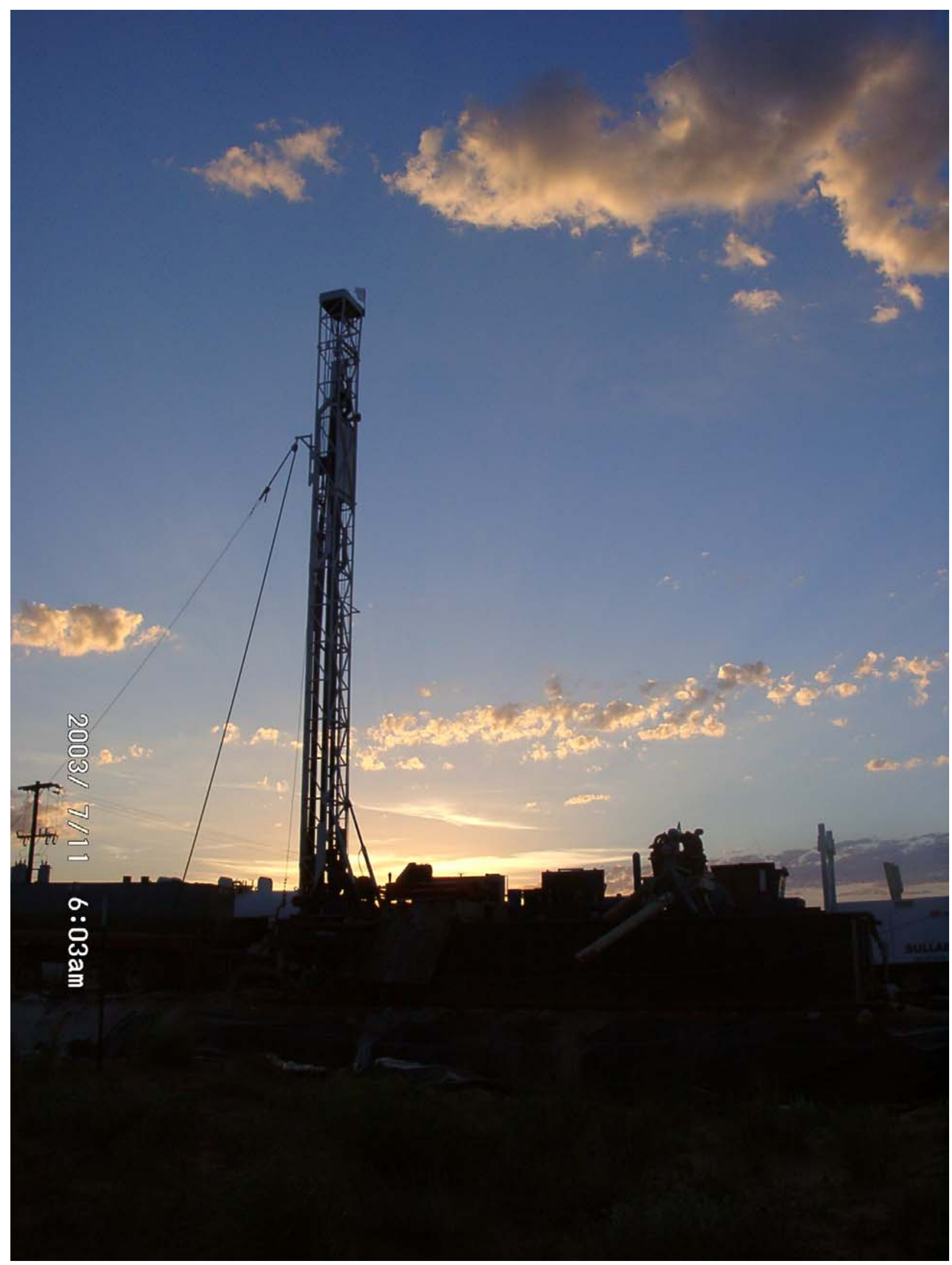

West Texas Water Well Service Rig \#15 at drillhole SNL-12, dawn, July 11, 2003. 


\section{EXECUTIVE SUMMARY}

SNL-12 (permitted by the New Mexico State Engineer as C-2954) was drilled to provide geological data and hydrological testing of the Culebra Dolomite Member of the Permian Rustler Formation near the margin of dissolution of halite in the upper part of the Salado south of the Waste Isolation Pilot Plant (WIPP). SNL-12 is located in the southeast quarter of section 20, T23S, R31E, in eastern Eddy County, New Mexico. SNL-12 was drilled to a total depth of $905 \mathrm{ft}$ below the ground level. Below surface dune sand and the Berino soil, SNL-12 encountered, in order, the Mescalero caliche, Gatuña, Dewey Lake, Rustler, and uppermost Salado Formations. Two intervals were cored: (1) from the lower Forty-niner Member through the Magenta Dolomite and into the upper Tamarisk Member; and (2) from the lower Tamarisk Member through the Culebra Dolomite and Los Medaños Members and into the uppermost Salado Formation. Geophysical logs were acquired from the open hole to total depth, and the drillhole was successfully completed with a screened interval open across the Culebra.

At SNL-12, the uppermost Salado cores display displacive halite crystals in clastic-rich units below an amalgamated sulfate at the top of the formation. There is no indication of thinning of the upper Salado due to postdepositional dissolution, and this is consistent with predrilling expectations. The Los Medaños has a thickness and stratigraphic sequence very similar to that found at the center of the WIPP site. The basal Los Medaños beds are laminar and show no signs of postdepositional dissolution of upper Salado halite. Higher clastic beds of the Los Medaños do not indicate postdepositional dissolution of halite either.

The Culebra Dolomite is above average in thickness (40 ft), and core recovery from the unit was very good. Recovered cores show a zone of probable öolites accounting for much of the greater than normal thickness. Bedding and porosity are generally similar to that across much of the WIPP site. Hydrostratigraphic units CU-3 and CU-2, normally the most transmissive parts of the Culebra, have been extended to include the öolite zone. Although these hydrostratigraphic zones are thicker than at the WIPP site, vugs and fracturing may be less extensive than in other drillholes.

The Tamarisk has a normal stratigraphic sequence and thickness, and the mudstone unit shows typical reddish-brown claystone overlain by gray and reddish-brown claystone. Some intraclasts of claystone are preserved. There is no indication of postdepositional dissolution of halite from the mudstone unit.

The Magenta Dolomite is about $28 \mathrm{ft}$ thick and shows typical laminar to wavy bedding, some ripples, minor algal stromatolites, and possible öolites. Only one fracture was observed, and there was little macroscopic evidence of porosity. Microresistivity indicates about $12 \mathrm{ft}$ of higher porosity in the upper part of the Magenta, which is consistent with other cores of the Magenta.

The Forty-niner is represented by a typical sulfate-mudstone-sulfate sequence. Cuttings indicate a typical color and lithologic sequence for the mudstone in the member.

The Dewey Lake was partially eroded, and the Santa Rosa completely removed, prior to deposition of the Gatuña. Cuttings and geophysical logs indicate that the sulfate-carbonate cement transition in the Dewey Lake is about $180 \mathrm{ft}$ below ground level at SNL-12, which is lower stratigraphically than the cement boundary is near the center of the WIPP site. A saturated zone with good quality water was encountered above this depth, and it is suggested that it is perched on the sulfate-cemented zone.

Most of the open drillhole below the Culebra was cemented before reaming. The drillhole was reamed to a diameter of 12.25 inches through the Culebra. Fiberglass reinforced plastic casing (4.83 inches o.d.) was placed in the hole, with a screen interval across the Culebra Dolomite. The annulus was filled with 8/16 Brady sand to just above the Culebra, and bentonite was placed on 
the sand to separate the Culebra from the Tamarisk mudstone. The annulus above the bentonite was cemented to the surface. The well was developed in August 2003, with several pumping and surge periods and with pumping rates ranging from about 16 to 26.5 gallons per minute. The fluid density of water from the Culebra was measured in the field as 1.02 grams per cubic centimeter $(\mathrm{g} / \mathrm{cc})$. The water level, measured March 8, 2004, was $2997.03 \mathrm{ft}$ above mean sea level. On April 5, 2004, the screen interval was cleaned by jetting, and the well was pumped for nearly 3 hours. The fluid density measured in the field was $1.004 \mathrm{~g} / \mathrm{cc}$. The measured water level on April 13, 2004, was $2998.94 \mathrm{ft}$ above mean sea level. 


\section{Table of Contents}

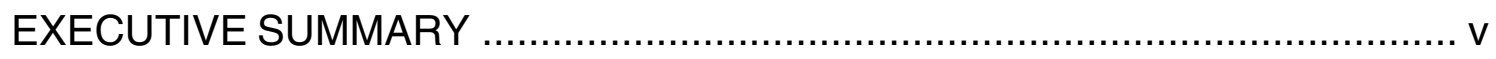

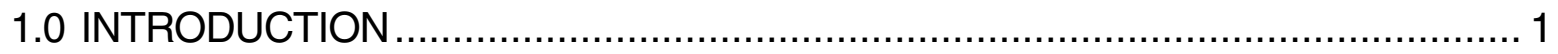

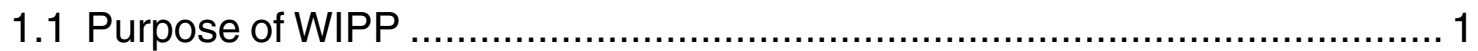

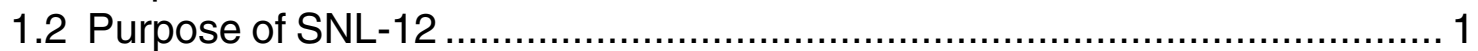

1.3 SNL-12 Drilling and Completion ....................................................... 4

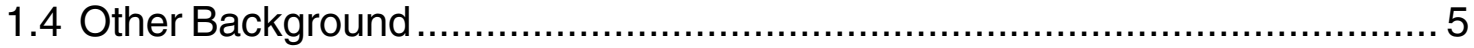

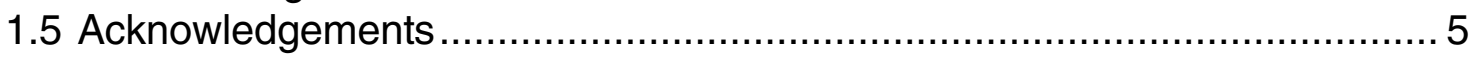

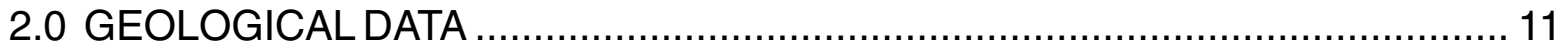

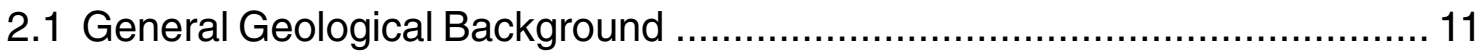

2.2 Geological Data From SNL-12 ….................................................. 11

2.2.1 Permian Salado Formation .................................................... 11

2.2.2 Permian Rustler Formation ............................................... 18

2.2.2.1 Los Medaños Member .............................................. 18

2.2.2.2 Culebra Dolomite Member ...................................... 22

2.2.2.3 Tamarisk Member ...................................................... 24

2.2.2.4 Magenta Dolomite Member ......................................... 27

2.2.2.5 Forty-niner Member ............................................... 29

2.2.3 Permo-Triassic Dewey Lake Formation ................................... 30

2.2.4 Miocene-Pleistocene Gatuña Formation .................................. 31

2.2.5 Pleistocene Mescalero Caliche ............................................. 31

2.2.6 Pleistocene Berino Soil and Surficial Sands ................................ 32

3.0 PRELIMINARY HYDROLOGICAL DATA FOR SNL-12 .................................. 33

3.1 Shallow Groundwater Above the Rustler Formation .............................. 33

3.2 Initial Results From the Magenta Dolomite ........................................ 33

3.3 Initial Results From the Culebra Dolomite ........................................ 33

3.4 Observations About the Rustler-Salado Contact ............................... 34

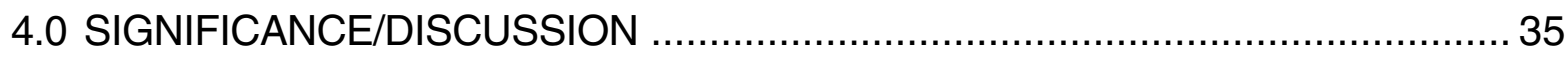

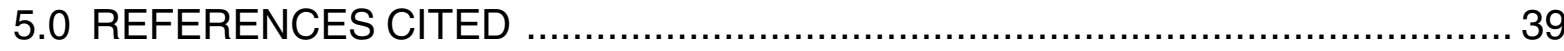

Appendix A ～- Drillhole Objectives ........................................................... 41

Appendix B ～- Abridged Borehole History ……........................................... 51

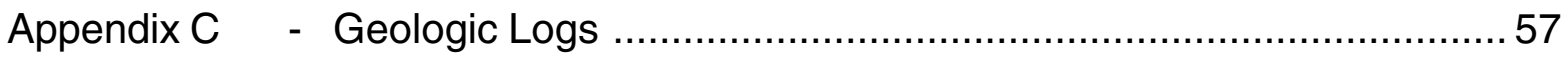


Table of Contents, cont.

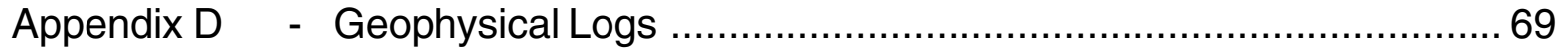

Appendix E - Additional Completion Information .......................................... 71

Appendix F - Archeological Clearance Report................................................ 95

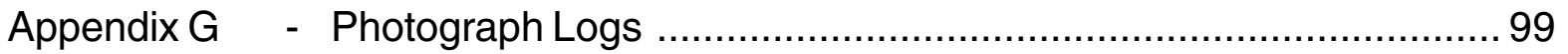




\section{List of Figures and Tables}

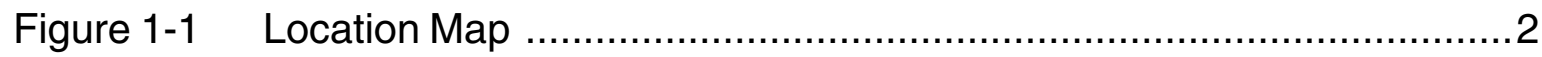

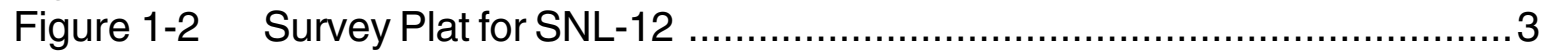

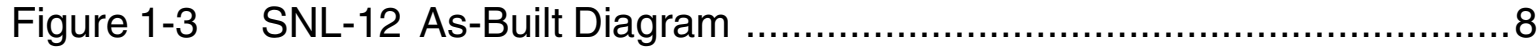

Figure 1-4 SNL-12 Completion and Monitoring Configuration ...........................9

Figure 1-5 SNL-12 Surface Configuration and Elevations .............................. 10

Figure 2-1 Well Record SNL-12 (C-2954) ............................................. 14-16

Figure 2-2 Core Features for the Upper Salado and

Basal Rustler Formations at SNL-12 ........................................ 17

Figure 2-3 Upper Salado Displacive Halite at SNL-12 …........................... 18

Figure 2-4 Rustler Units at SNL-12 ..................................................... 19

Figure 2-5 Unfractured Thin Beds at the Base of the Rustler Formation

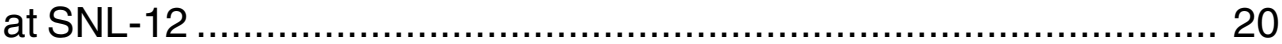

Figure 2-6 Bedding in Upper M-2 at SNL-12 …...................................... 23

Figure 2-7 Culebra Dolomite Member of the Rustler Formation at SNL-12 ... 25-26

Figure 2-8 Magenta Dolomite Member of the Rustler Formation at SNL-12 ....... 28

Figure 3-1 Culebra Water Elevation at SNL-12 …..................................... 34

Figure 4-1 Location of SNL-12 Relative to Upper Salado Dissolution Margin .... 37

Table 1-1 Summary of Drilling and Well Completion Records for Hydrologic Drillhole SNL-12 (C-2954) .........................................

Table 2-1 Geology at Drillhole SNL-12 ……….................................... 12

Table 3-1 Culebra Water Levels Measured in SNL-12 ................................ 34

In keeping with practice at the WIPP site, the basic data for SNL-12 are reported in the inch-pound, or English, system; metric equivalents are given in one figure. The following conversion factors for metric equivalents may be useful:

$\begin{array}{lc}\text { MULTIPLYENGLISHUNIT } & \text { BY } \\ \text { foot (ft) } & 0.3048 \\ \text { inch (in) } & 25.4 \\ \text { inch (in) } & 2.54 \\ \text { pounds (lb) } & 0.4536\end{array}$

TO OBTAIN METRIC UNIT meter $(\mathrm{m})$ millimeter (mm) centimeter $(\mathrm{cm})$ kilogram $(\mathrm{kg})$ 


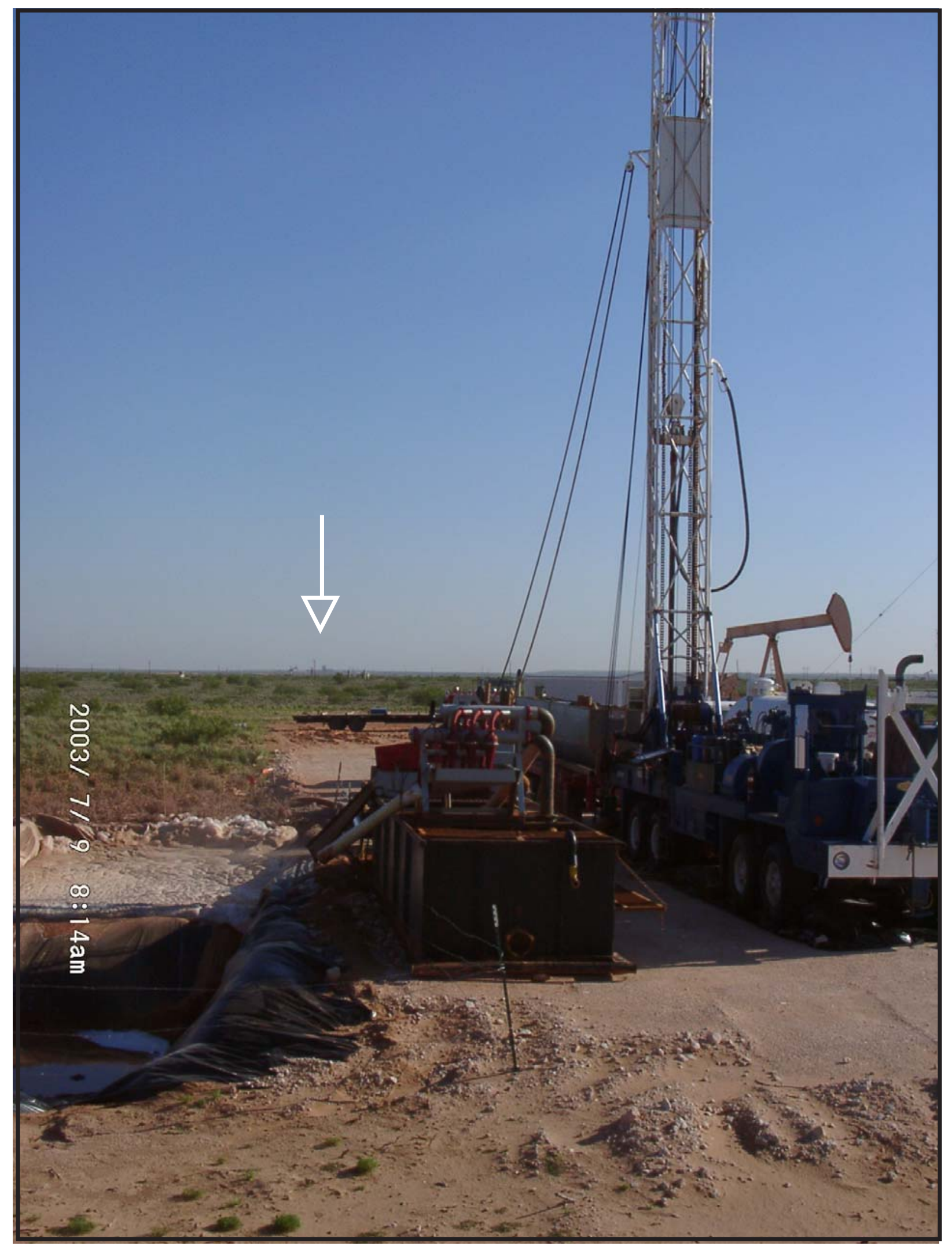

West Texas Water Well Service rig \#15 at SNL-2 in a view toward north showing relationship to WIPP site (on horizon, below arrow). The oil well visible behind the rig is Pure Gold "B" Federal \#6. 


\subsection{INTRODUCTION}

SNL-12 was drilled in the southeast quarter of section 20, T23S, R31E, in eastern Eddy County, New Mexico (Fig. 1-1). It is located $1711 \mathrm{ft}$ from the south line (fsl) and $2137 \mathrm{ft}$ from the east line (fel) of the section (Fig. 1-2). This location places the drillhole near the southeast arm of Nash Draw among oil wells of the Sand Dunes field. SNL-12 will be used to test hydraulic properties and to monitor ground water levels of the Culebra Dolomite Member of the Permian Rustler Formation.

SNL-12 was permitted by the New Mexico State Engineer as C-2954. [Official correspondence regarding permitting and regulatory information must reference this permit number.] In the plan describing the integrated groundwater hydrology program (Sandia National Laboratories, 2003), SNL-12 is also co-designated WTS-10 because the location also satisfies needs for longterm monitoring of water levels and flow rate and direction in the Culebra Dolomite for Resource Conservation and Recovery Act permit compliance; this program is under the management of Washington TRU Solutions LLC (WTS).

Most drillholes at WIPP have been described after completion to provide an account of the geology, hydrology, or other basic data acquired during drilling and immediate completion of the drillhole. In addition, the basic data report provides an account of the drilling procedures and activities that may be helpful to later interpretations of data or for further work in the drillhole, including test activities and eventual plugging and abandoning activities. The basic data report also provides a convenient means of reporting information about administrative activities necessary to drill the hole.

\subsection{Purpose of WIPP}

WIPP is a U.S. Department of Energy (DOE) facility disposing of transuranic and mixed waste, byproducts of U.S. defense programs, as certified by the U.S. Environmental Protection Agency (EPA) and under a permit issued by the New Mexico Environment Department. WIPP is located about 25 miles east of Carlsbad, New Mexico, in eastern Eddy County (Fig. 1-1). Disposal panels are being excavated in the Permian Salado Formation at a depth of about $2,150 \mathrm{ft}$ below ground level (bgl)

\subsection{Purpose of SNL-12}

SNL-12 was designed and located to provide information for the integrated hydrology program for WIPP (Sandia National Laboratories, 2003). Among the objectives of the integrated hydrology program, SNL-12 will help “... resolve questions related to observed water-level changes around the WIPP site, provide data needed for comprehensive modeling of WIPP groundwater hydrology, [and] construct a groundwater monitoring network that can be maintained throughout the operational period of WIPP ..." (p. 1).

Culebra water levels in many of the wells monitored for WIPP have been rising in recent years, contrasting with the conditions used to calibrate models of the Culebra across the site area (Sandia National Laboratories, 2003) for the Compliance Certification Application (CCA; U.S. Department of Energy, 1996). Hydraulic properties of the Culebra vary spatially, and three factors (overburden, upper Salado dissolution, and Rustler halite distribution) appear to explain most of the variability in transmissivity (Holt and Yarbrough, 2002; Powers and others, 2003). SNL-12 was located to test Culebra hydraulic properties near the upper Salado dissolution margin as well as confirming the geological conditions used to estimate Culebra hydraulic properties (Sandia National Laboratories, 2003; Powers, 2002a, 2003a; Powers and others, 2003).

The drillhole is to (Sandia National Laboratories, 2003, p. 40; see also Appendix A):

1. Confirm that the high transmissivity south of the site indicated by our models exists;

2. Determine if dissolution of the upper Salado has occurred in this area; 


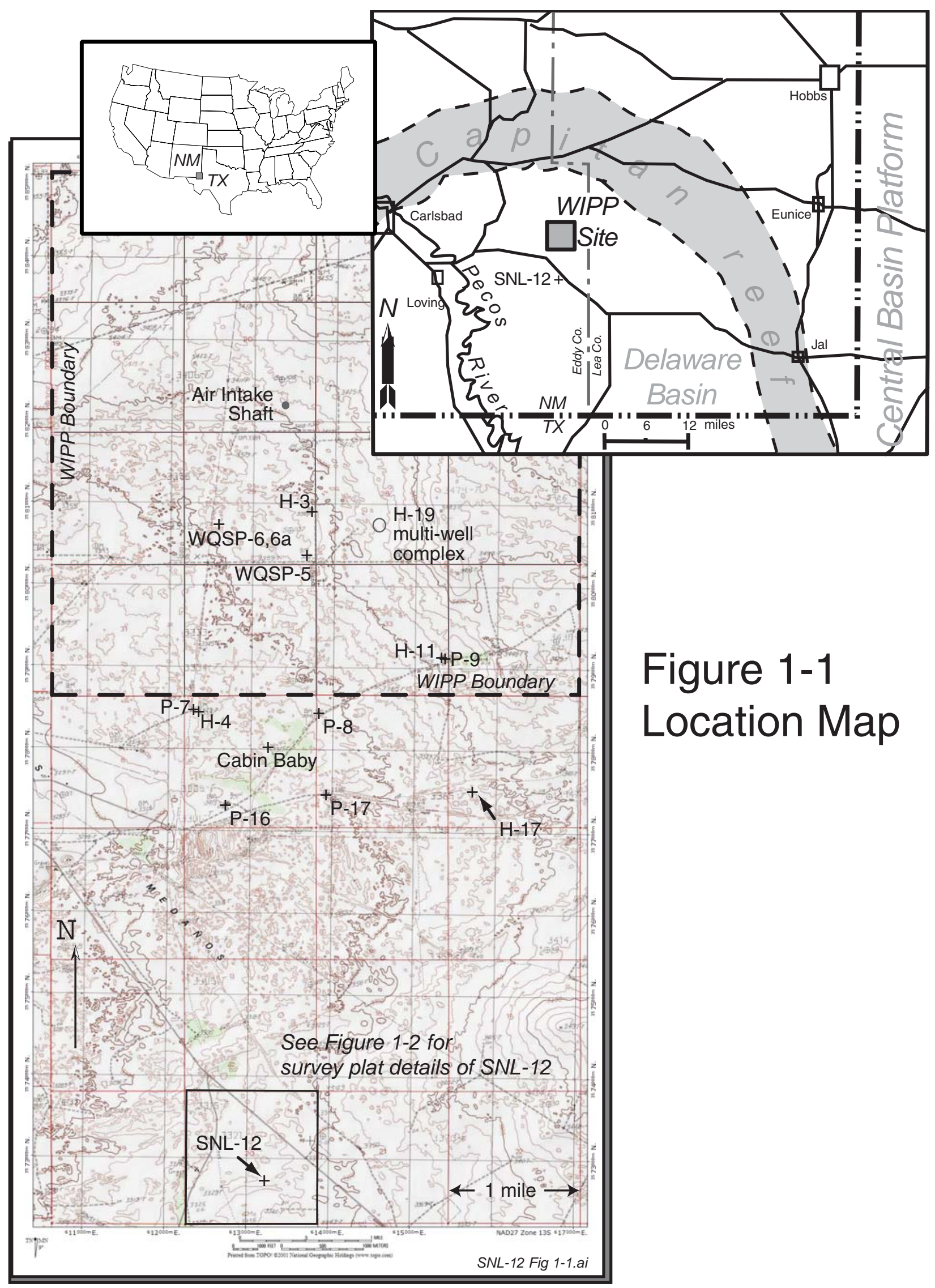




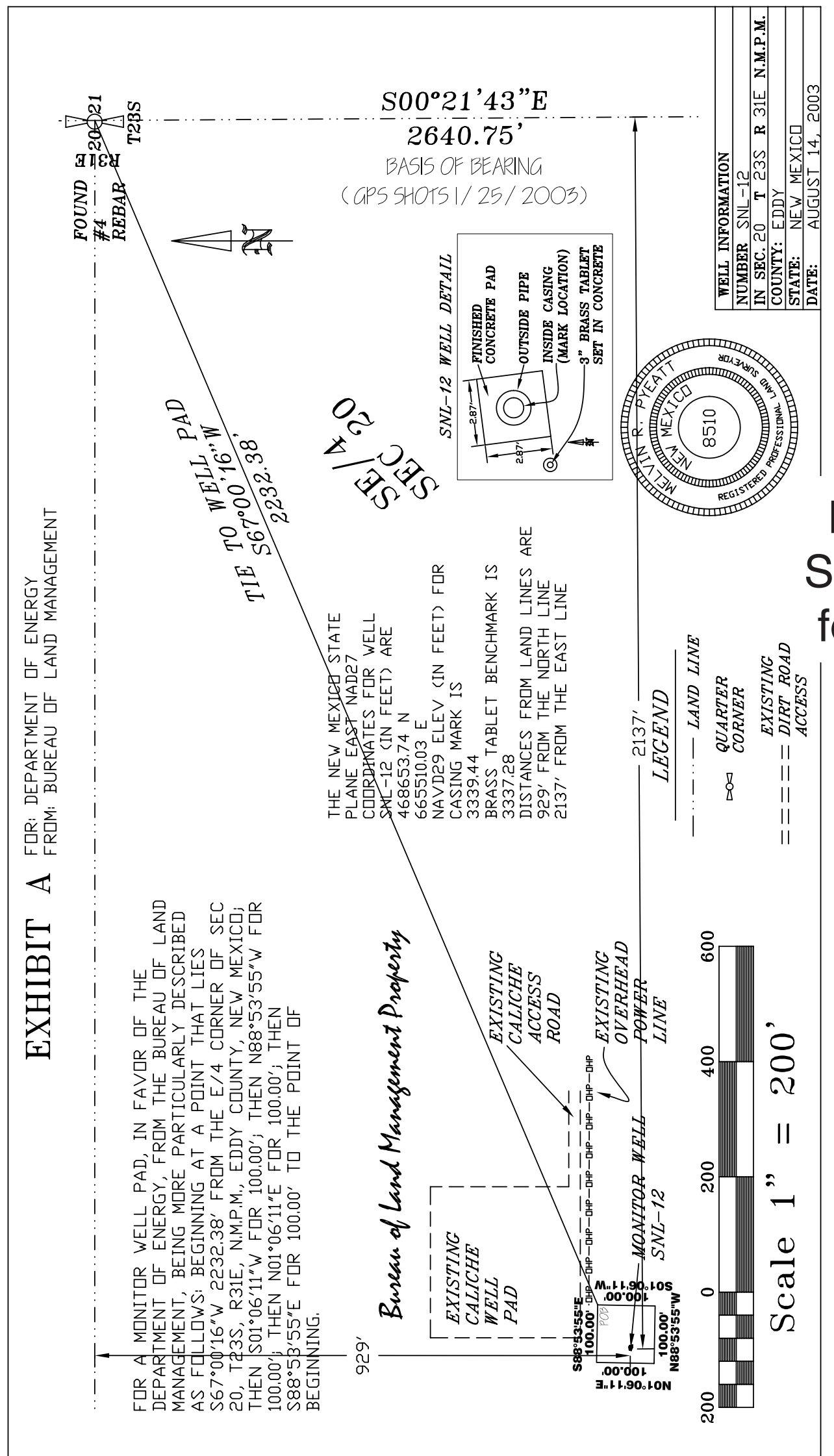


3. Determine if the dimensionality of flow (inferred from a pumping test) indicates that the high transmissivity is channelized (focused) or is widely distributed (diffuse);

4. Provide another monitoring point to help determine the source and/or cause of the water-level changes regularly observed at $\mathrm{H}-9$;

5. Provide information on Culebra heads in an area with many nearby oil and gas wells; and

6. Provide a pumping location for a large-scale (multipad) test to provide transient data for calibration of the Culebra model south of the WIPP site.

\subsection{SNL-12 Drilling and Completion}

The basic information about drilling and completion of SNL-12 is presented here in tabular form (Table 1-1) and graphics (Figs. 1-3, 1-4, and 1-5) for ease of reference. Appendix B includes details based on daily drilling logs.

SNL-12 was rotary drilled and cored to a total depth of $905 \mathrm{ft}$ bgl (Fig. 1-3). As the drillhole progressed, circulating fluids were successively changed from air to fresh-water mist with foam to brine with foam to brine with surfactant. The changes reflect needs for determining geological and hydrological conditions in the drillhole as well as maintaining control of drillhole conditions.

Core recovery ranged from excellent to poor (Appendix C), and this experience is common in these intervals (e.g., Powers, 2002b; Mercer and others, 1998).

In keeping with recent practice at WIPP, SNL-12 was cased with fiberglass reinforced plastic (FRP) casing rather than steel to provide longer utility of the well for monitoring and testing. Steel-cased wells at WIPP are expected to be plugged and abandoned and, where necessary, replaced with wells completed similar to SNL-12 (Sandia National Laboratories, 2003).

SNL-12 was completed with a single screened interval for monitoring and testing of only the Culebra Dolomite (Fig. 1-4). With a single completion interval, some of the difficulties associated with multiple completions can be avoided: expense of buying, placing, and maintaining packers; loss of water level data when packers fail; mixing of waters of differing qualities when packers fail; and the increased complexity of testing in a well completed to multiple intervals. Although units other than the Culebra bear water at SNL-12, including the Dewey Lake Formation, the program plan does not refer to additional monitor or pump wells on the SNL-12 wellpad (Sandia National Laboratories, 2003).

Geophysical logs, especially the natural gamma and caliper logs, were used to make the final decisions regarding completion of SNL-12 (Fig. 1-4) (Appendices D and E). The drillhole was cemented back to a level below the Culebra to protect the lower Rustler from circulation of Culebra water (Fig. 1-4). The bottom of the Culebra screen interval was placed at $584 \mathrm{ft}$ to remain above the claystone below the Culebra and avoid possible plugging of the lowermost slots (Fig. 1-4). The top of the screen, at $546 \mathrm{ft}$, is above the top of the Culebra. The top of the sand/gravel pack (8/16 silica sand) at $540 \mathrm{ft}$ is below the level of the mudstone in the Tamarisk to prevent connection to the Culebra. Baroid Holeplug from $540-535 \mathrm{ft}$ also prevents circulation between the Culebra and the Tamarisk mudstone. The annulus above the seal at $535 \mathrm{ft}$ was cemented to the surface.

A final caliper log (Fig. 1-3), obtained after the drillhole was reamed to 12.25 inches and before the casing was placed, shows drillhole enlargement in the Forty-niner and Tamarisk mudstones, and also at the contact between the Dewey Lake and Rustler Formations. The caliper log (Fig. 1-3) also shows that the drillhole diameter decreased through the Culebra, similar to the experience at drillhole C-2737 (Powers, 2002b). Above $180 \mathrm{ft}$, the drillhole diameter is somewhat irregular and diminished from the nominal reaming diameter; this zone corresponds to the upper Dewey Lake where sulfate cements are not present (see section 2.0). 
The surface configuration (Fig. 1-5) provides stability, security, and ready access to the casing for measurements, sampling, or other testing. The surface benchmark is an accessible reference point for future measurements if the well configuration is changed. Geophysical logs and depths for FRP casing, screen, and fill in the annulus are measured from the top of the connector on the steel surface conductor casing. The top of FRP casing was cut off $2 \mathrm{ft}$ above this point before the outer protective steel casing was threaded to the connector on the steel surface conductor casing. The cement pad was poured around the surface conductor casing and connector.

\subsection{Other Background}

SNL-12 was drilled and completed by the West Texas Water Well Service, 3410 Mankins, Odessa, Texas, under contract from WTS. Coring was done by John W. Wood, Diamond Oil Well Drilling Co., Inc., P.O. Box 7843, Midland, Texas. Geophysical logging was conducted by Raymond Federwisch, Geophysical Logging Services, 6250 Michele Lane, Prescott, Arizona, under contract to West Texas Water Well Service. Geological support was provided by Dennis W. Powers under contract to WTS. Mike Stapleton of the New Mexico Office of the State Engineer witnessed hole completion activities (Appendix E). Archeological clearances obtained from the U.S. Bureau of Land Management were based on field work and reports by Mesa Field Services, P.O. Box 3072, Carlsbad, New Mexico (Appendix F). Cores from SNL-12 were photographed with digital cameras, and a photo log is included in Appendix G. Electronic images can be requested from WTS.

\subsection{Acknowledgements}

Drafts of this document were reviewed by Mark Crawley, Wayne Stensrud, Rick Salness, Joel Siegel, and Rick Beauheim, and their comments improved the final report. Mark Crawley (Washington Regulatory and Environmental
Services - WRES) provided field support and information on well development. Doug Lynn (WRES) obtained permits and provided permitting and regulatory information included in appendix material. Ronnie Keith and Rodney Dutton (West Texas Water Well Service) provided drilling data and daily drilling records. West Texas Water Well Service personnel were very helpful in providing access for sampling during drilling. Raymond Federwisch (Geophysical Logging Services) provided the printed and electronic files that were used to develop Figure 2-1. Chris Mahoney checked certain files and figures and provided data files for sections. Vivian Allen (L\&M Technologies) provided useful editorial and formatting guidance. 


\section{Table 1-1. Summary of Drilling and Well Completion Records for Hydrologic Drillhole SNL-12 (C-2954)}

LOCATION: Southeast $1 \frac{1}{4}$, section 20, Township 23 South (T23S), Range 31 East (R31E)

SURFACE COORDINATES: The well is located 1,171 $\mathrm{ft}$ from the south line ( $\mathrm{fsl}$ ) and 2,137 $\mathrm{ft}$ from the east line (fel) of section 20. The New Mexico State Plane (NAD 27) horizontal coordinates in feet are 468653.74 North, 665510.03 East (Figure 1-2 shows the survey plat). UTM horizontal coordinates (NAD27, Zone 13) in meters were calculated for SNL-12 using Corpscon for Windows (v. 5.11.08): 3572728.40 North, 613209.67 East. Figure 1-1 shows UTM coordinates on a 1000-m grid.

ELEVATION: All depths used in geological and geophysical data here were measured from the top of the connector on the steel surface conductor casing, at about ground level. Depths are reported bgl, which is taken as 3,337 ft above mean sea level (amsl), the rounded value for the brass tablet benchmark $(3,337.28 \mathrm{ft}$ amsl $)$ adjacent to the cement well pad. The primary datum for the completed well is 3,339.44 ft amsl (NAVD 29) for a mark on the top of the FRP casing inside the protective well pipe. Figures 1-3, 1-4, and 1-5 show the as-built configuration of SNL-12.

\section{DRILLING RECORD:}

Dates: Began drilling June 25, 2003; drillhole reamed to completion depth (600 ft) on July 24, 2003. Final geophysical logging was conducted on July 24, 2003. Drillhole was prepared for casing, and was cased and cemented July 29, 2003. Rig was taken down July 30,2003. SNL-12 well was developed by pumping on August 4, 2003, and April 5, 2004.

Circulation Fluid: The surface conductor casing pilot hole was drilled to $30 \mathrm{ft}$ bgl with circulating air and was then reamed to 18-inch diameter with Baroid Quik-Foam ${ }^{\circledR}$ and fresh water mist driven by compressed air. SNL-12 was drilled to $175 \mathrm{ft} \mathrm{bgl}$ with circulating air. The saturated zone in the Dewey Lake Formation caused cuttings to cake in the drillhole, and Baroid Quik-Foam ${ }^{\circledR}$ and fresh water mist driven by compressed air were used to drill and core to $577 \mathrm{ft} \mathrm{bgl,} \mathrm{partially} \mathrm{through} \mathrm{the} \mathrm{Culebra}$ Dolomite. From $577 \mathrm{ft}$ bgl to total depth $(905 \mathrm{ft} \mathrm{bgl})$, the drillhole was cored and drilled using circulating brine with Flowzan ${ }^{\circledR}$ biopolymer (MSDS\# 463650) in a portable mud pit. After geophysical logging and plugging the lower part of the drillhole, SNL-12 was reamed to a final diameter (12.25 inches) to $600 \mathrm{ft}$ using circulating brine with Flowzan ${ }^{\circledR}$ biopolymer (MSDS\# 463650) in a portable mud pit.

Cored Intervals: 4.0 -inch core was taken through these intervals (depths from drilling data): 425.0-470.5 ft bgl: lower Forty-niner, Magenta Dolomite, and upper Tamarisk Members 520.0-720.0 ft bgl: lower Tamarisk, Culebra Dolomite, and Los Medaños Members; and upper Salado Formation

Rig and Drilling Contractor: Gardner-Denver 1500, Rig \#15; West Texas Water Well Service, Odessa, Texas 


\section{Table 1-1. Summary of Drilling and Well Completion Records for Hydrologic Drillhole SNL-12 (C-2954), continued.}

Drillhole Record:

\begin{tabular}{|c|c|c|}
\hline Size (inches) & From (ft bgl) & To (ft bgl) \\
\hline \hline 18 & 0 & 30 \\
\hline 12.25 & 30 & 600 \\
\hline 7.875 & 600 & 905 \\
\hline
\end{tabular}

Casing Record:

\begin{tabular}{|r|c|l|r|r|}
\hline $\begin{array}{c}\text { Outside diameter } \\
\text { (inches) }\end{array}$ & $\begin{array}{c}\text { Inside diameter } \\
\text { (inches) }\end{array}$ & $\begin{array}{c}\text { Weight/ft } \\
\text { (pounds) }\end{array}$ & $\begin{array}{c}\text { From } \\
\text { (ft bgl)* }\end{array}$ & $\begin{array}{c}\text { To } \\
\text { (ft bgl) }\end{array}$ \\
\hline 13.38 & 12.72 & 48 steel & 0 & 30 \\
\hline 4.83 & 4.33 & 3.20 FRP** blank & -2 & 546.0 \\
\hline 4.83 & 4.33 & 3.20 FRP screen & 546.0 & 584.0 \\
\hline 4.83 & 4.33 & 3.20 FRP blank & 584.0 & 595.0 \\
\hline
\end{tabular}

* Reference point for logging and completion is the top of the connector on the surface conductor casing, which is $\sim$ ground level. The blank FRP extends $\sim 2 \mathrm{ft}$ above this connector.

$* *$ FRP $=$ fiberglass reinforced plastic

\section{Coring Record:}

\begin{tabular}{|c|r|r|r|r|r|}
\hline $\begin{array}{c}\text { Core Run } \\
\text { No. }\end{array}$ & \multicolumn{2}{|c|}{$\begin{array}{c}\text { Depth Interval (ft) } \\
\text { From }\end{array}$} & \multicolumn{2}{c|}{$\begin{array}{c}\text { Interval (ft) } \\
\text { To }\end{array}$} & $\begin{array}{c}\text { Recovered } \\
\text { Recovered }\end{array}$ \\
\hline \hline 1 & 425 & 454 & 29 & 29 & $100.00 \%$ \\
\hline 2 & 454 & 470 & 16 & 16.5 & $103.13 \%$ \\
\hline 3 & 520 & 548 & 28 & 28.3 & $101.07 \%$ \\
\hline 4 & 548.3 & 577.3 & 29 & 29 & $100.00 \%$ \\
\hline 5 & 577.3 & 600 & 22.7 & 22.7 & $100.00 \%$ \\
\hline 6 & 600 & 610 & 10 & 10 & $100.00 \%$ \\
\hline 7 & 610 & 638 & 28 & 18 & $64.29 \%$ \\
\hline 8 & 638 & 666 & 28 & 20 & $71.43 \%$ \\
\hline 9 & 666 & 690.5 & 24.5 & 17.8 & $72.65 \%$ \\
\hline 10 & 690.5 & 720 & 29.5 & 30 & $101.69 \%$ \\
\hline & & Totals & 244.7 & 221.3 & $90.44 \%$ \\
\hline
\end{tabular}

Note: Marked core depths (e.g., Appendix C) vary slightly from core interval depths partly due to differing recoveries and estimates of lost core intervals. Recovery $>100 \%$ results from recovery of core left in the drillhole on a previous run, from measurement discrepancies, or from core not fitting together precisely when laid out for marking. 


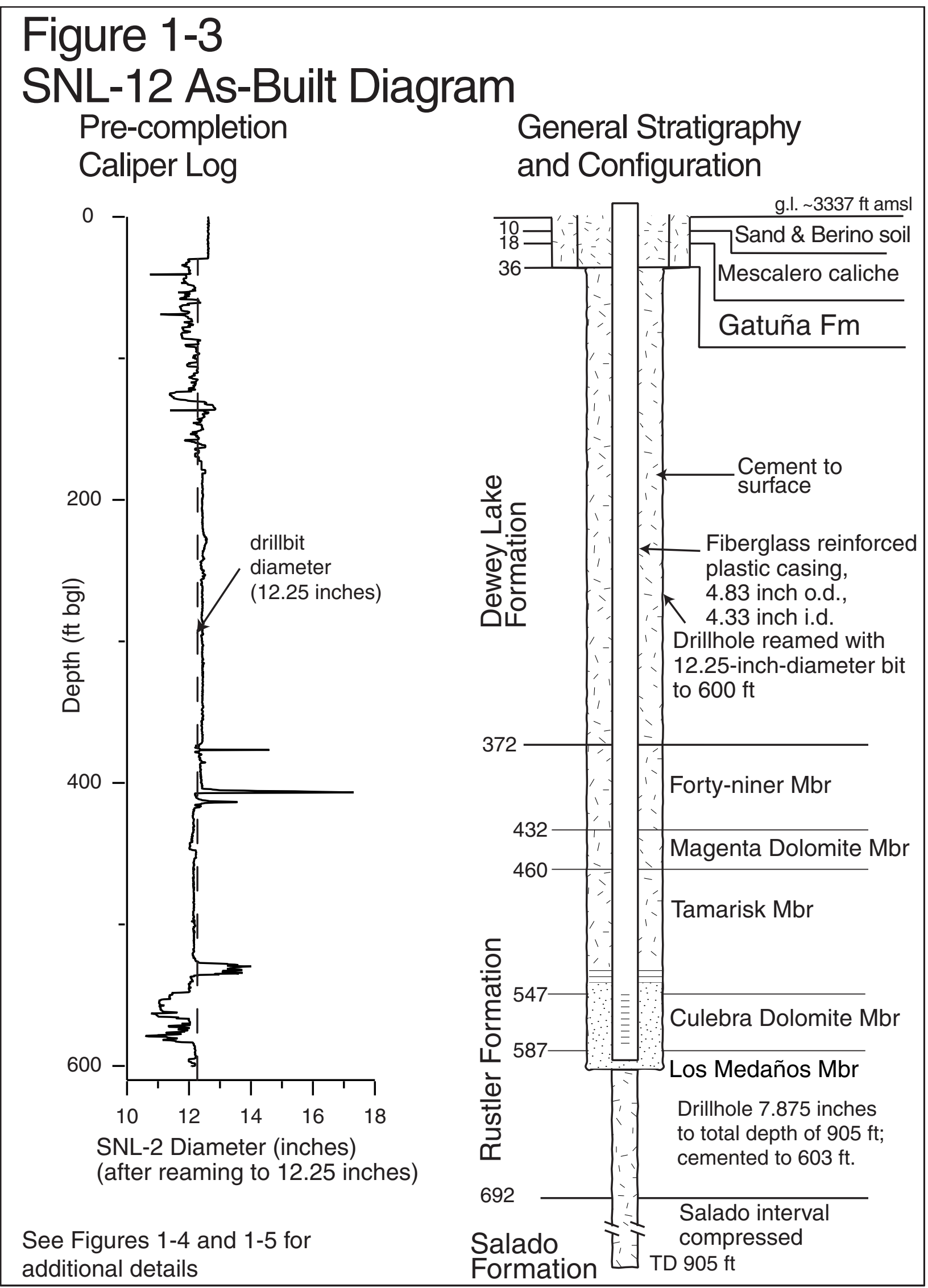




\section{Figure 1-4 \\ SNL-12 Completion and \\ Monitoring Configuration (7/29/03)}

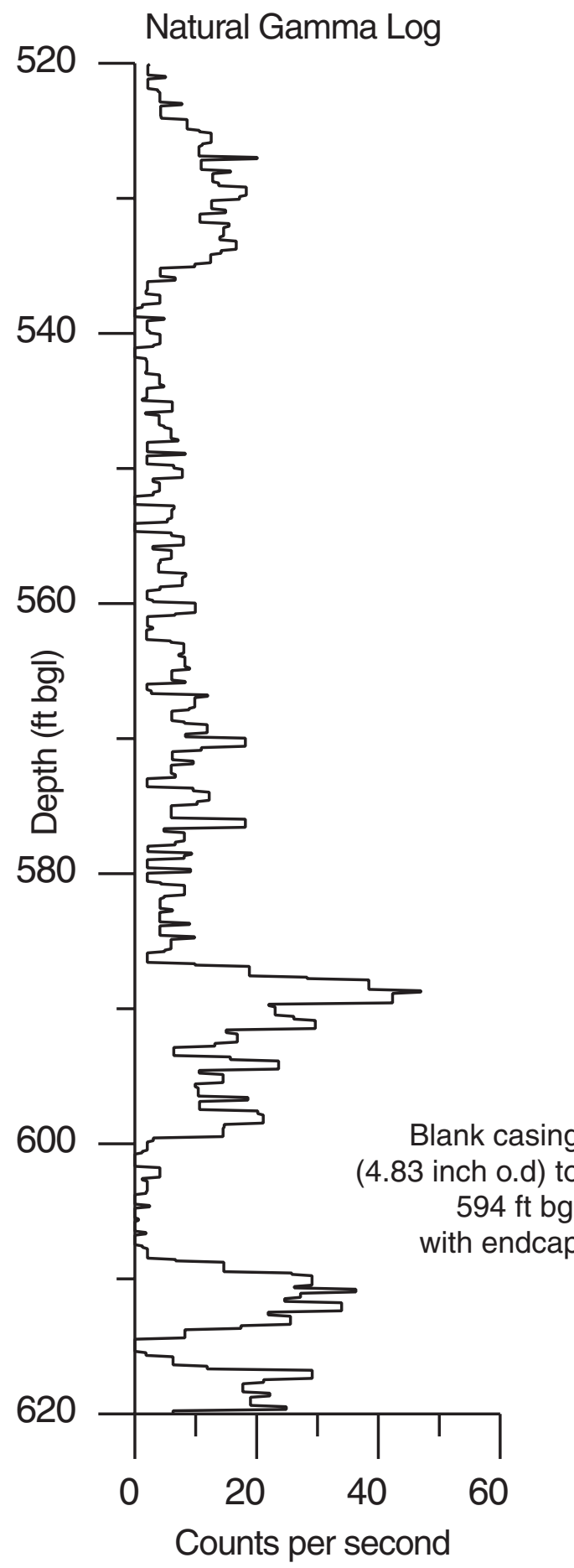

Completed Configuration

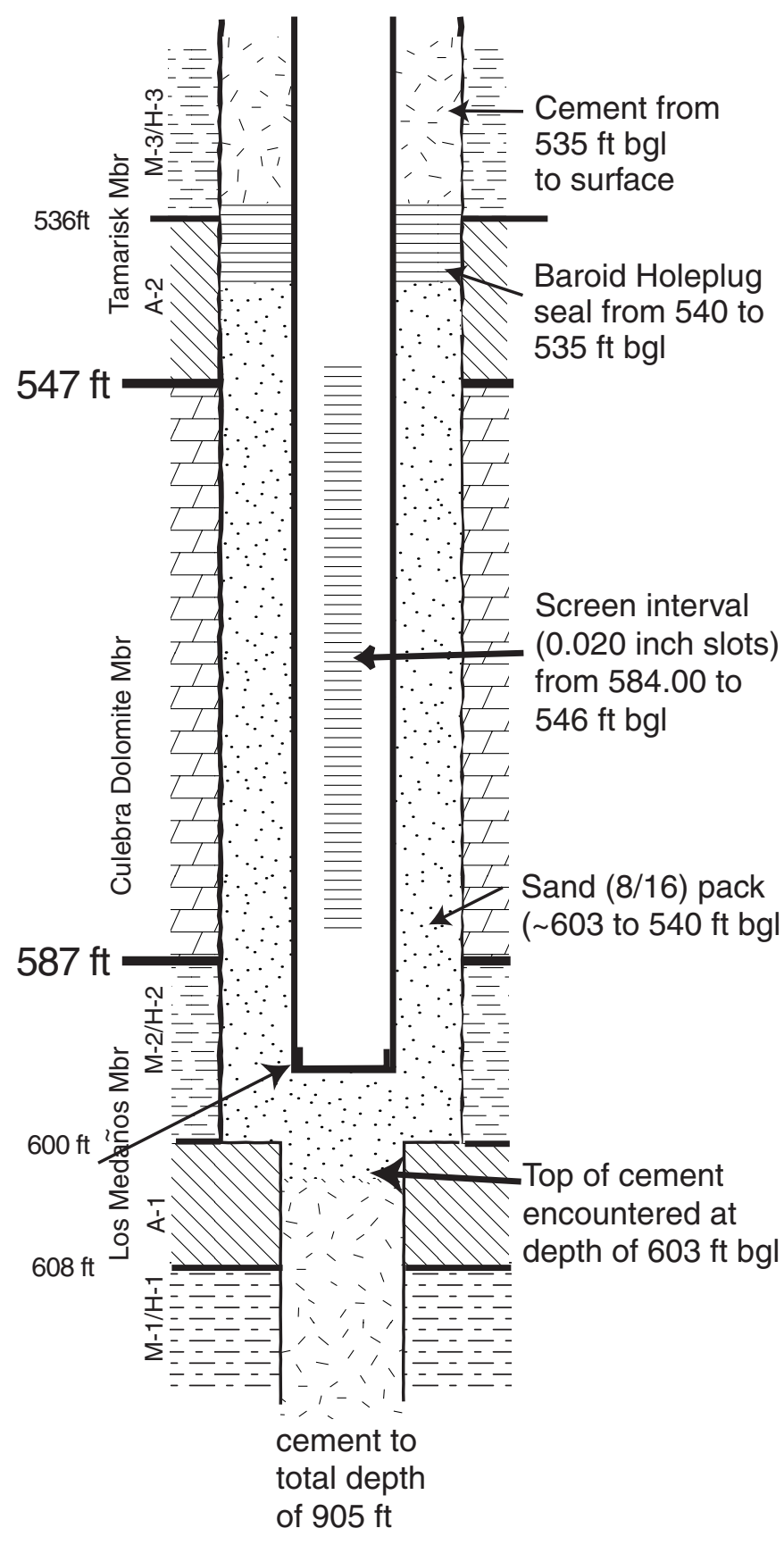




\section{Figure 1-5}

SNL-12 Surface Configuration and Elevations (7/29/03)
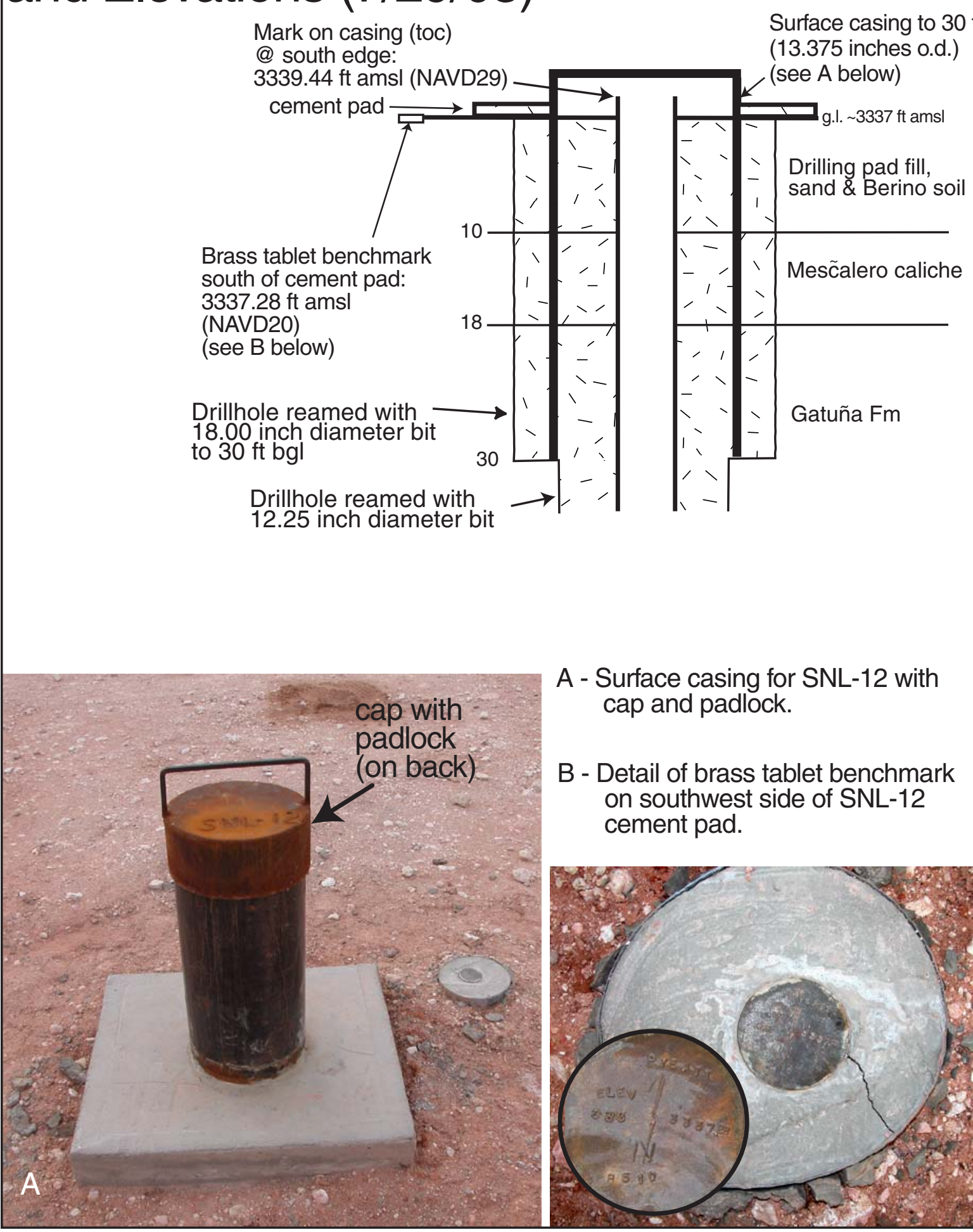

A - Surface casing for SNL-12 with cap and padlock.

B - Detail of brass tablet benchmark on southwest side of SNL-12 cement pad.

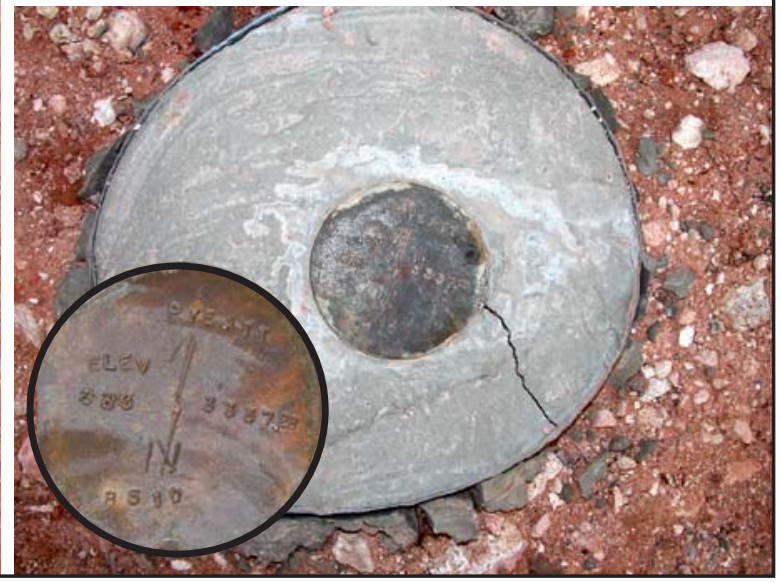




\subsection{GEOLOGICAL DATA}

\subsection{General Geological Background}

The geology and hydrology of formations at the WIPP site and surroundings have been intensively investigated since 1975, and the information and interpretations have been reported in numerous documents. The most thorough compilation is certainly the Compliance Certification Application (CCA) submitted in 1996 by the DOE to the EPA (U.S. Department of Energy, 1996). Some salient features of the broader geological history, as well as more recent work on the geohydrology of the Rustler (e.g., Holt and Yarbrough, 2002; Powers, 2002a; Powers and others, 2003), are relevant to understanding the geology and hydrology at SNL-12.

The Delaware Basin (Fig. 1-1) was a large structural feature that controlled deposition through much of the Paleozoic. By late Permian, the basin connection to the open ocean was restricted, and evaporite minerals were precipitated in abundance. The basin filled with sediments, and it no longer significantly affected sedimentation. Near the end of the Permian, circulation with the ocean improved, and some of the Rustler Formation, for example, was deposited in saline water rather than brine. As the Permian ended and Triassic began, continental environments prevailed, and significant redbeds were deposited. Although surrounding areas accumulated variable thicknesses of later Mesozoic and Cenozoic age sediments, the WIPP area appears to have mainly been subject to erosion during an extended period. Some basin tilting from mid-to-late Cenozoic exposed the evaporite beds to faster solution and erosion, and weathered material began to accumulate. The Pecos River drainage became integrated through the region during this period, and more recent deposits reflect such a sedimentary environment as well as sources of sediment from outside the local area. Although the region continues to be subject to some dissolution of evaporites and erosion, large areas have remained geologically stable for approximately the last half million years, resulting in the formation and preservation of pedogenic calcrete (caliche) deposits.

\subsection{Geological Data From SNL-12}

SNL-12 encountered a normal stratigraphic sequence for the area south of the WIPP site and adjacent to the southeast arm of Nash Draw, from ground level to total depth (Table 2-1; Fig. 2-1). Units encountered ranged from unconsolidated surficial sands to the upper part of the Permian Salado Formation. No unusual structural, sedimentological, or diagenetic features were found during investigation using cuttings, cores, and geophysical $\operatorname{logs}$, although details of the sedimentology of the Rustler will extend understanding of that unit. Groundwater was encountered in the Dewey Lake Formation during drilling.

The geologic units encountered in SNL-12 are described from total depth to the surface, in the order in which they were deposited rather than in the order in which they were encountered in the drillhole. Cores and cuttings were described in the field using mainly drilling depths for depth control. The difference between geophysical logs and drilling depths is generally slight. The largest differences commonly resulted from depths and core markings through intervals of partial core recovery when compared to later geophysical logs. Decisions about placing screen intervals and annulus fillings were based on depths indicated by geophysical logs (Appendix D). Geologic logs detailing field observations of cuttings and cores are included in Appendix C.

Note that the descriptions that follow use depths that correspond to core markings, with basic stratigraphic intervals provided by geophysical logs, as indicated.

\subsubsection{Permian Salado Formation}

Approximately $28 \mathrm{ft}$ of the uppermost Salado were cored in SNL-12, and an additional $185 \mathrm{ft}$ 


\begin{tabular}{|c|c|c|c|c|}
\hline \multicolumn{5}{|c|}{$\begin{array}{c}\text { Table } 2-1 \\
\text { Geology at Drillhole SNL-12 }\end{array}$} \\
\hline & $\begin{array}{c}\text { System/ } \\
\text { Period/Epoch }\end{array}$ & Formation or unit & $\begin{array}{c}\text { Member } \\
\text { Informal units }\end{array}$ & Depth below surface (ft $)^{1}$ \\
\hline \multirow{3}{*}{ نِّ } & Holocene & surface dune sand and & & $0-10 \mathrm{ft}$ \\
\hline & Pleistocene & Mescalero caliche & & $10-18 \mathrm{ft}$ \\
\hline & Miocene-Pleistocene & Gatuña & & $18 \mathrm{ft}-36 \mathrm{ft}$ \\
\hline \multirow{2}{*}{$\frac{\substack{0 \\
0}}{\substack{0 \\
0}}$} & \multirow[b]{2}{*}{ Triassic } & Santa Rosa ${ }^{2}$ & & eroded \\
\hline & & Dewey Lake ${ }^{3}$ & & $36 \mathrm{ft}-372 \mathrm{ft}$ \\
\hline \multirow{6}{*}{ 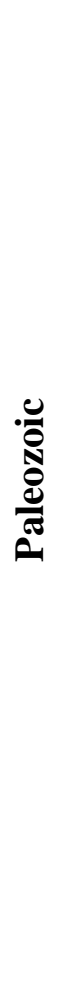 } & \multirow{6}{*}{ Permian } & \multirow{5}{*}{ Rustler } & $\begin{array}{c}\text { Forty-niner } \\
A-5 \\
M-4 / H-4 \\
A-4\end{array}$ & $\begin{array}{l}372 \mathrm{ft}-432 \mathrm{ft} \\
372 \mathrm{ft}-403 \mathrm{ft} \\
403 \mathrm{ft}-418 \mathrm{ft} \\
418 \mathrm{ft}-432 \mathrm{ft}\end{array}$ \\
\hline & & & Magenta Dolomite & $432 \mathrm{ft}-460 \mathrm{ft}$ \\
\hline & & & $\begin{array}{c}\text { Tamarisk } \\
A-3 \\
M-3 / H-3 \\
A-2\end{array}$ & $\begin{array}{l}460 \mathrm{ft}-547 \mathrm{ft} \\
460 \mathrm{ft}-524 \mathrm{ft} \\
524 \mathrm{ft}-536 \mathrm{ft} \\
536 \mathrm{ft}-547 \mathrm{ft}\end{array}$ \\
\hline & & & Culebra Dolomite & $547 \mathrm{ft}-587 \mathrm{ft}$ \\
\hline & & & $\begin{array}{c}\text { Los Medaños }^{4} \\
M-2 / H-2 \\
A-1 \\
M-1 / H-1\end{array}$ & $\begin{array}{l}587 \mathrm{ft}-692 \mathrm{ft} \\
587 f t-600 \mathrm{ft} \\
600 \mathrm{ft}-608 \mathrm{ft} \\
608 \mathrm{ft}-692 \mathrm{ft}\end{array}$ \\
\hline & & Salado & $\begin{array}{l}\text { ?Marker Bed } 100 \\
\text { Marker Bed } 101 \\
\text { Marker Bed } 102 \\
\text { Marker Bed } 103\end{array}$ & $\begin{array}{c}692 \text { - total depth }(905 \mathrm{ft}) \\
?-785 ? \mathrm{ft} \\
822 \mathrm{ft}-825 \mathrm{ft} \\
845 \mathrm{ft}-850 \mathrm{ft} ? \\
879 \mathrm{ft}-894 \mathrm{ft}\end{array}$ \\
\hline
\end{tabular}

${ }^{1}$ Depths are based on measurements by geophysical logging supplemented by drilling data.Geological logs based on field descriptions (Appendix C) and markings on cores (Appendix G) vary modestly because of incomplete recovery and lesser precision using cuttings.

${ }^{2}$ The Santa Rosa Formation, part of the Dockum Group or undifferentiated Triassic, is completely eroded at SNL-12.

${ }^{3}$ The Dewey Lake Formation has been considered part of the Permian System in the past. Recent work (Renne and others, 1996, 2001) indicates that lithologically equivalent rocks in Texas are mostly Lower Triassic, with some Upper Permian at the base.

${ }^{4}$ The Los Medaños Member was named by Powers and Holt (1999) to replace the informal unit "unnamed lower member" of the Rustler Formation. 
were drilled and logged with geophysical tools. The core provides a record of the transition from the Salado to the Rustler and any dissolution that may have affected the upper Salado or basal Rustler.

The program plan (Sandia National Laboratories, 2003) outlined a potential drilling target of a marker bed (MB) in the upper Salado. Powers (2002a, 2003a) estimated before drilling that this location had not been affected by dissolution of upper Salado halite, based on the thickness of the interval between the Culebra and the Vaca Triste Sandstone Member of the Salado in surrounding industry drillholes. The core provides direct stratigraphic and textural evidence to investigate any dissolution at the top of the Salado. Drilling beyond the uppermost Salado to an identifiable marker bed (possibly MB103) was expected to help in relating thickness changes of the larger stratigraphic interval to dissolution, if any, of upper Salado halite.

The upper Salado is dominated by coarse halite ranging in color from white to orangish or reddishbrown from included accessory minerals. SNL-12 also intercepted anhydrite to polyhalite $\left[\mathrm{K}_{2} \mathrm{Ca}\left(\mathrm{SO}_{4}\right)_{2} \cdot 2 \mathrm{H}_{2} \mathrm{O}\right]$ marker beds in the upper Salado and thin argillaceous beds.

A white anhydrite, $\sim 15 \mathrm{ft}$ thick, is estimated to occur from $\sim 879-894 \mathrm{ft}$, based on changes in drilling rates and cuttings returned at the surface. This bed is considered to be MB103; it is similar in thickness and stratigraphic position to MB103 in other drillholes in the area (Powers, 2002a).

A polyhalite and halite unit from $\sim 845-850 \mathrm{ft}$ is believed to be MB 102. This unit is widespread, but it is not as thick or uniform as MB 103. The identification, based mainly on cuttings, is tentative.

Based on limited data from cuttings and geophysical $\log$ s, MB 101 is inferred from $\sim 770-778 \mathrm{ft}$. Resistivity and density logs indicate lithologies generally consistent with this marker bed. Black claystone cuttings (returned to the surface after the drillhole had reached $\sim 785 \mathrm{ft}$ ) are consistent with high natural gamma from 778-782 ft, which is a likely position for an underclay for this unit. This inferred location for
MB101 is not sufficiently reliable to use as an indicator of thickness changes across the Salado-Rustler contact due to local or regional dissolution.

Several depositional cycles (both Type 1 and Type 2, Lowenstein, 1988) are represented in the cores from the uppermost Salado (Fig. 2-2), with sequences similar to those described by Holt and Powers (1990a,b). The basal halite beds of the depositional cycle are commonly coarse halite with few disseminated impurities, some thin bedding (2-8 inches), and some discontinuous thin sulfate laminae along bedding (stratified mud-poor halite - smph; Fig. 2-2). Above this basal part of the cycle, the halite crystals tend to become smaller vertically, and clay (and sometimes polyhalite) content increases upward (muddy halite-mh, possibly podular; Fig. 2-2). Halitic mudstone or claystone generally marks the upper part of a cycle.

At the top of the cycle at $712 \mathrm{ft}$, some claystone accumulated before the next depositional cycle began with sulfate, which was later converted to polyhalite. Sandy siltstone accumulated at the top of the Type 1 cycle at $703.4 \mathrm{ft}$. Halite crystals grew displacively in the clastic material included in the intervals from 711.7-703.4 ft and 703.3-694.7 ft. Bedding is generally poorly displayed within the clastic-rich parts of the depositional cycles. Syndepositional solution surfaces are likely at $715.3 \mathrm{ft}, 714.3 \mathrm{ft}$, and $713.5 \mathrm{ft}$. Reddish-orange polyhalite, $\sim 0.3 \mathrm{ft}$ thick, at $712 \mathrm{ft}$ may not be the beginning of a Type 1 cycle; the upper surface is undulatory, appears corroded by dissolution, and displays small features that are possible halite-filled desiccation cracks.

From 694.7-692.1 ft, thin bedded gypsum and reddish brown siltstone and sandstone mark the uppermost Salado Formation (Fig. 3-3). The beds are modestly disrupted, and appear to have been amalgamated as a unit. Whether this is by syndepositional dissolution of some halite or by local facies variations is undetermined from macroscopic evidence. The overlying beds are not disturbed. 


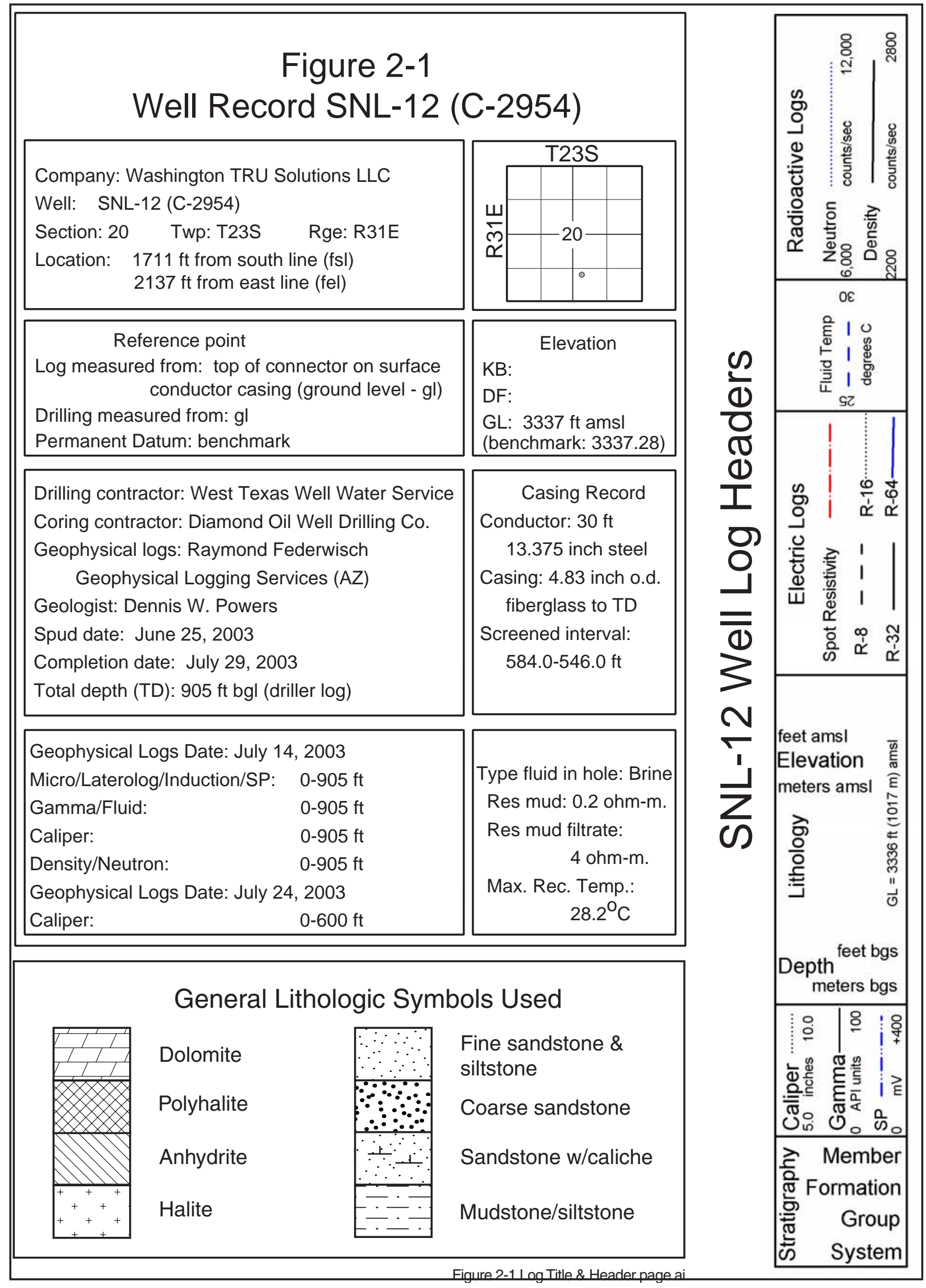




\begin{tabular}{|c|c|c|c|c|c|c|c|c|}
\hline 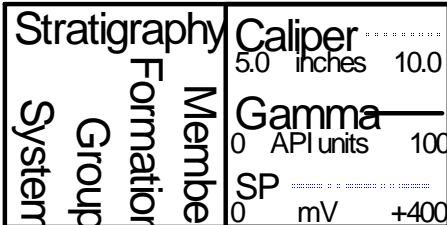 & 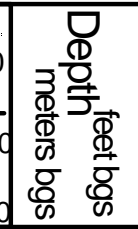 & 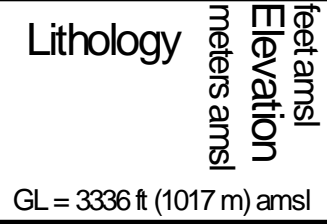 & $\begin{array}{r}\text { Electric } \\
\text { Spot Resistivity } \\
\mathrm{R}-8=- \\
\mathrm{R}-32-\end{array}$ & $\begin{array}{l}\mathrm{R}-16 \\
\mathrm{R}-64\end{array}$ & $\stackrel{2}{\text { Fluid Temp }}$ degrees C & $\begin{array}{c}\text { Radió } \\
\text { Neutron } \\
6,000 \\
\text { Density } \\
2200\end{array}$ & $\frac{\text { counts/sec }}{\text { counts/sec }}$ & \\
\hline
\end{tabular}
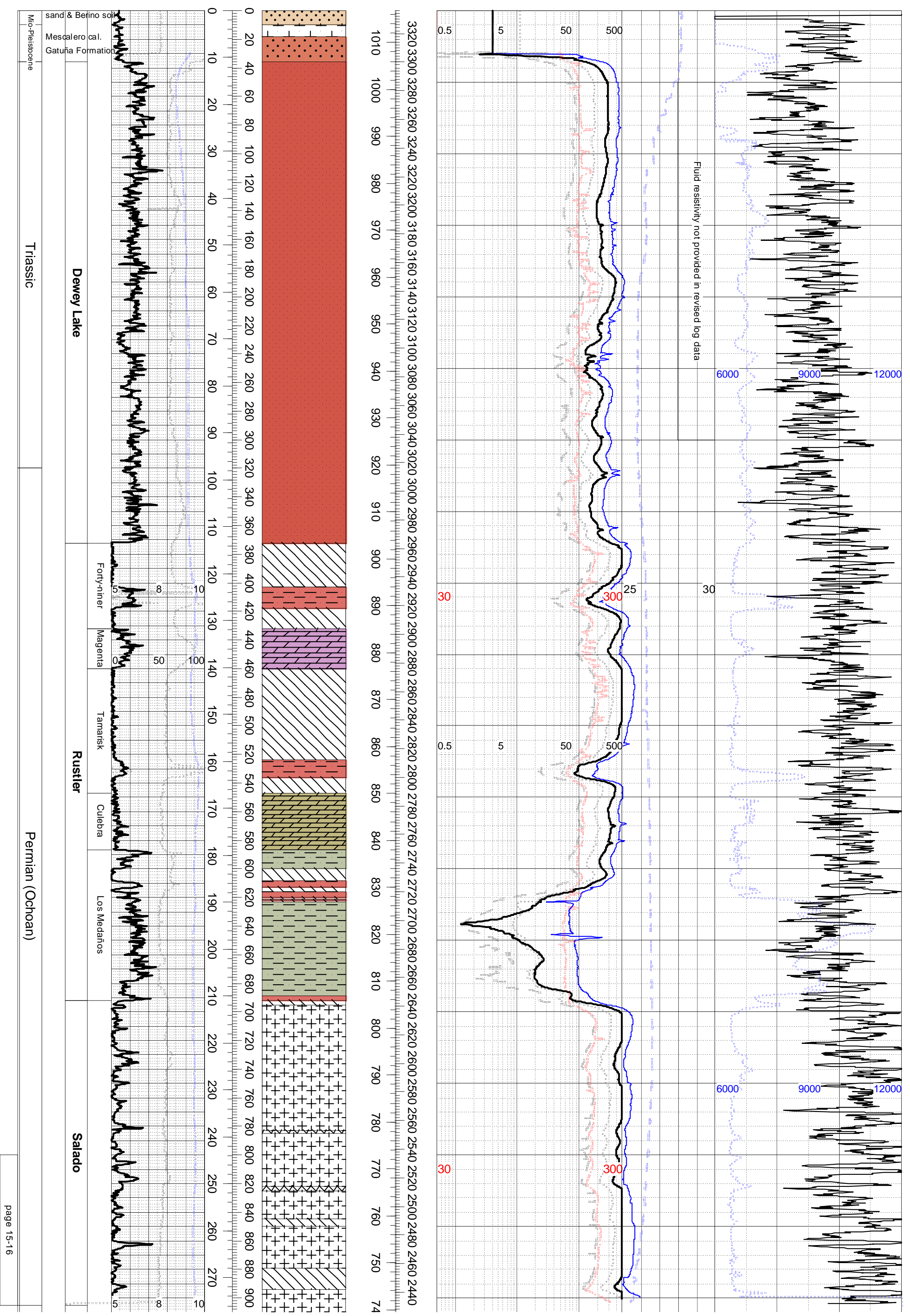


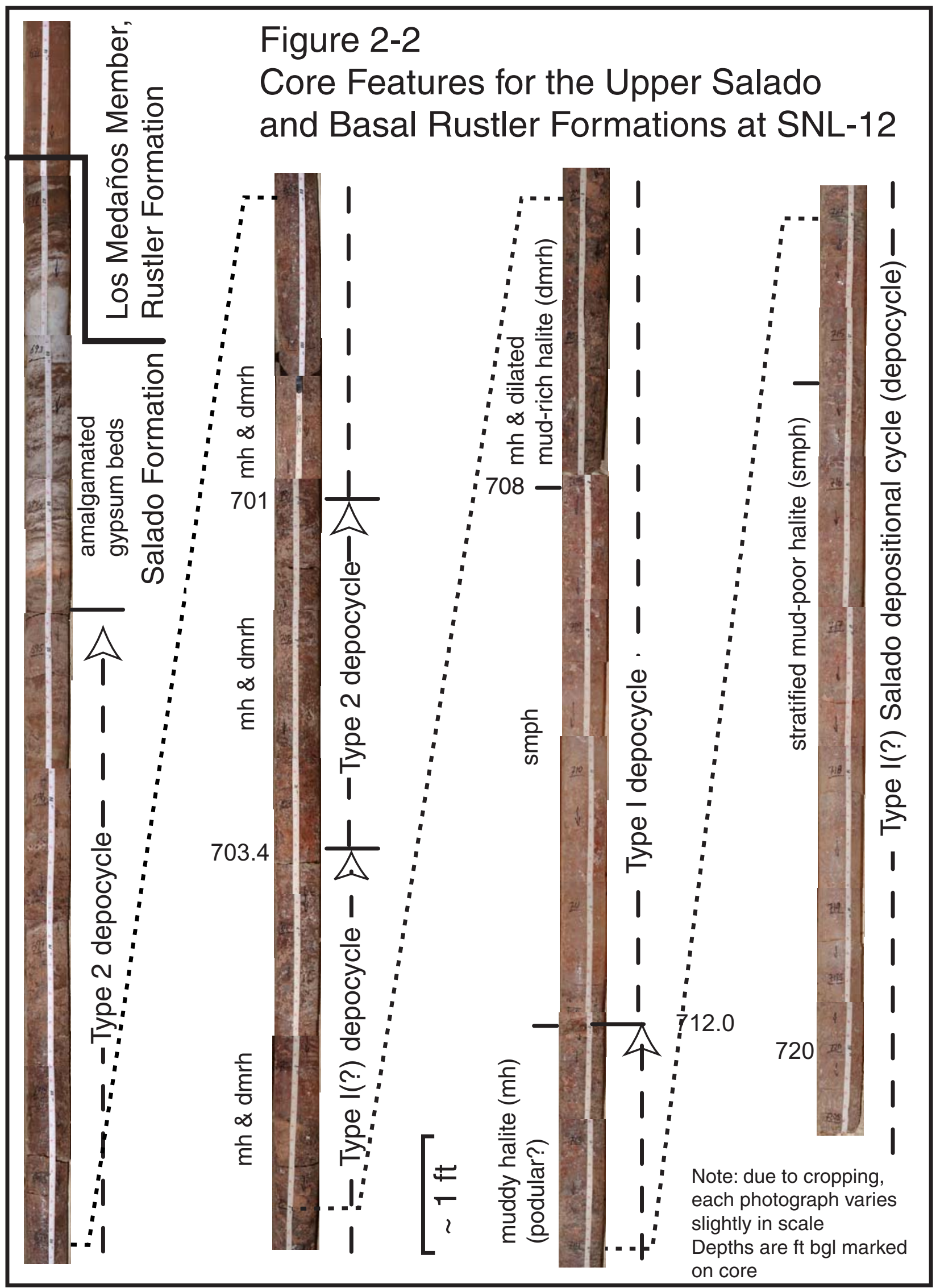




\section{Figure 2-3 Upper Salado Displacive Halite at SNL-12}

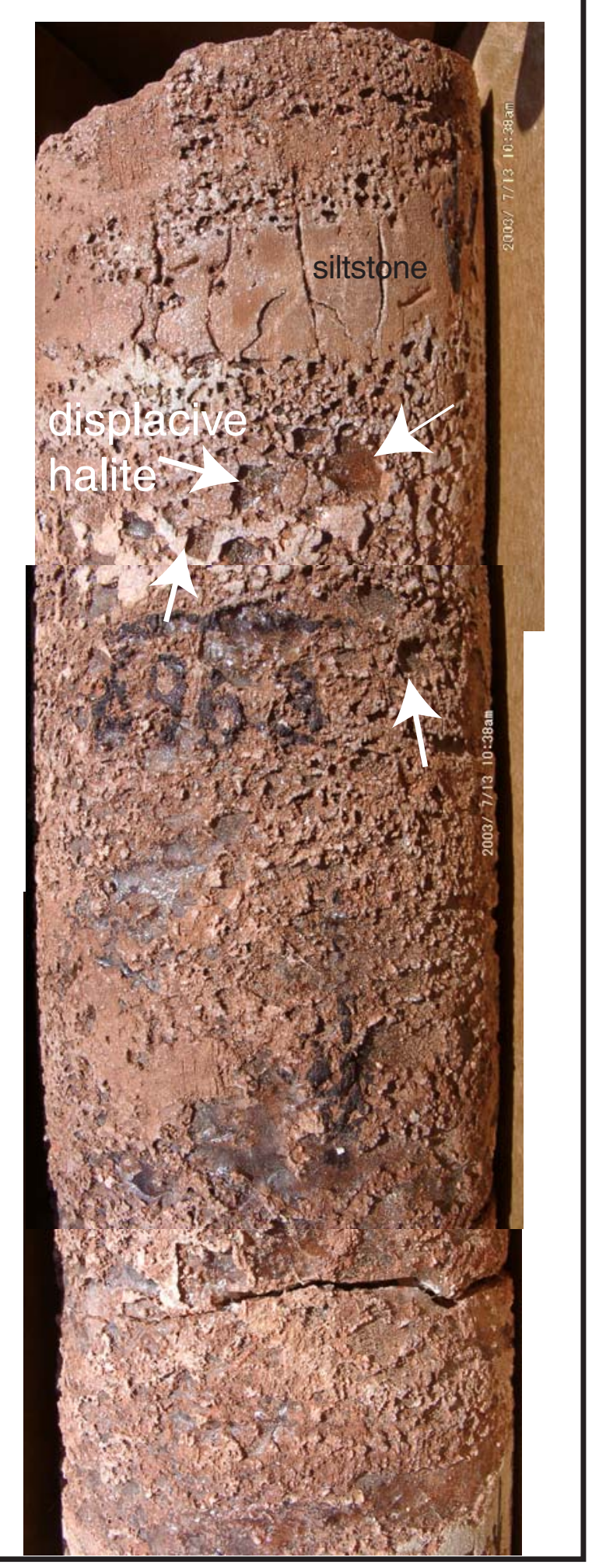

The muddy halite below the Salado-Rustler contact at SNL-12 reveals a variety of sedimentary textures relevant to interpreting whether dissolution has affected the upper Salado. Displacive halite margins are commonly visible (e.g., Fig. 2-3; $\sim 696.2-696.3 \mathrm{ft}$ ) in some beds. Some of the halite appears to have corroded margins. A thin siltstone bed (Fig. 2-3) may have both displacive and corroded halite margins at its base. The siltstone also shows narrow vertical separations that may be due to desiccation.

\subsubsection{Permian Rustler Formation}

The Rustler was completely drilled. The contact with the underlying Salado Formation is at $692 \mathrm{ft}$, based on geophysical logs; the boundary marked on the core is at $692.1 \mathrm{ft}$. The contact between the Rustler and the overlying Dewey Lake Formation is at $372 \mathrm{ft}$, based on geophysical logs, and the total Rustler thickness at SNL-12 is $320 \mathrm{ft}$.

\subsubsection{Los Medaños Member}

The Los Medaños Member of the Rustler Formation was named by Powers and Holt (1999) based on the rocks described in shafts at the WIPP site. For the area around WIPP, studies of the Rustler have commonly referred to this interval from the base of the Culebra Dolomite Member to the top of the Salado Formation as the unnamed lower member of the Rustler. Holt and Powers (1988) and Powers and Holt (1999) also informally subdivided the Los Medaños into five units: a bioturbated clastic interval at the base, a sandy transition zone, a lower mudstone-halite 1 (M-1/H-1), anhydrite-1 (A-1), and an upper mudstone-halite $2(\mathrm{M}-2 / \mathrm{H}-2)$. Halite margins for the Los Medaños below A-1 have been treated as a single composite unit (Powers, 2002a), called M-1/H-1 (Fig. 2-4), because halite below A-1 is not restricted to the thinner zone designated $\mathrm{M}-1 / \mathrm{H}-1$ in these earlier publications.

The Los Medaños occurs from $692-587 \mathrm{ft}$ at SNL-12. The entire thickness (105 ft) of the Los Medaños was cored, although portions of the upper part were only partially recovered. 
The informal unit mudstone-halite 1 unit (M-1/H-1; Fig. 2-4) (Holt and Powers, 1988) is considered here to extend from the top of the Salado at $692 \mathrm{ft}$ to $608 \mathrm{ft}$ (based on geophysical logs), and it includes the bioturbated clastic interval and sandy transition without separation. Approximately $10 \mathrm{ft}$ of core were lost from core run 7 (610-638 ft). It was assumed during drilling that the loss occurred from $\sim 610-620 \mathrm{ft}$, and the uppermost core from this interval was therefore marked as $620 \mathrm{ft}$ (Appendix C, sheet 7). The gray anhydrite marked from $624.8-627.9 \mathrm{ft}$ is now believed to correspond to the diminished natural gamma from 613-616 ft. Nearly five ft of core above the anhydrite also correspond to the five $\mathrm{ft}$ thick geophysical log interval between the base of anhydrite 1 (at $608 \mathrm{ft}$; see below) and the top of this additional anhydrite. The core loss from run 7 more likely occurs at the base of the recovered core. Nevertheless, the core is not being remarked.

At the base of M-1/H-1 at SNL-12, $\sim 2.6 \mathrm{ft}$ (692.1-689.5 ft) of reddish brown (2.5YR4/4; Munsell Soil Color Chart, 1971 edition; colors are from dry samples unless noted as wet) fine sandstone overlies the anhydrite considered the top of Salado (Figs. 2-2, 2-5). The sandstone has wellpreserved thin beds and laminae (Fig. 2-5) that appear to be undisturbed by fracturing or tilting. Probable claystone intraclasts are preserved in the middle of the unit, but there is no obvious erosional contact like that found slightly above the base of the Rustler in other cores (e.g., Powers and Richardson, in review) and shafts (Holt and Powers, 1990a,b; Powers and Holt, 1999). This sandstone appears to be fining upward, and bedding becomes more wavy upward. This reddish brown section also appears to be partially cemented by gypsum.

From $\sim 689.5-679 \mathrm{ft}, \mathrm{M}-1 / \mathrm{H}-1$ is dominated by grayish brown (2.5Y5/2), silty, argillaceous sandstone. Bedding ranges from faint to thin laminae, with some low-angle cross-bedding or ripples near the base and top of the unit. Small holes near the top indicate possible bioturbation; and there are possible small pelecypod molds at $\sim 681-681 \mathrm{ft}$.

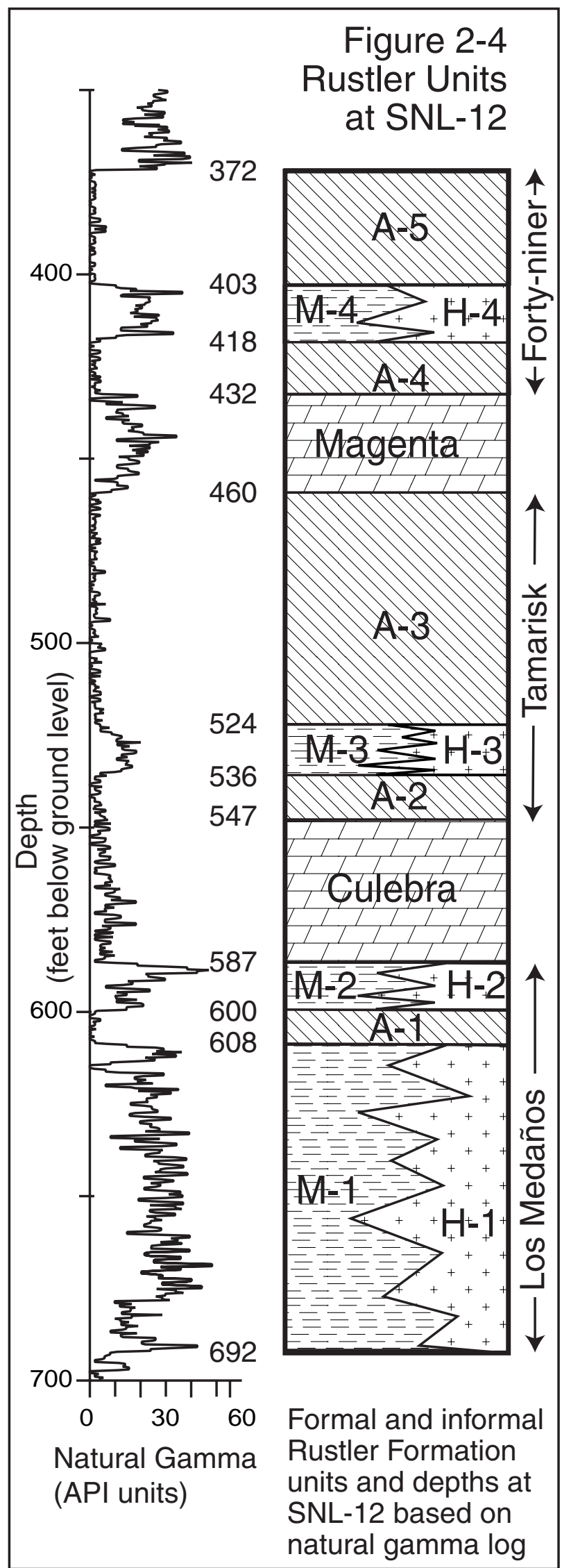


Figure 2-5 Unfractured Thin Beds at the Base of the Rustler Formation at SNL-12

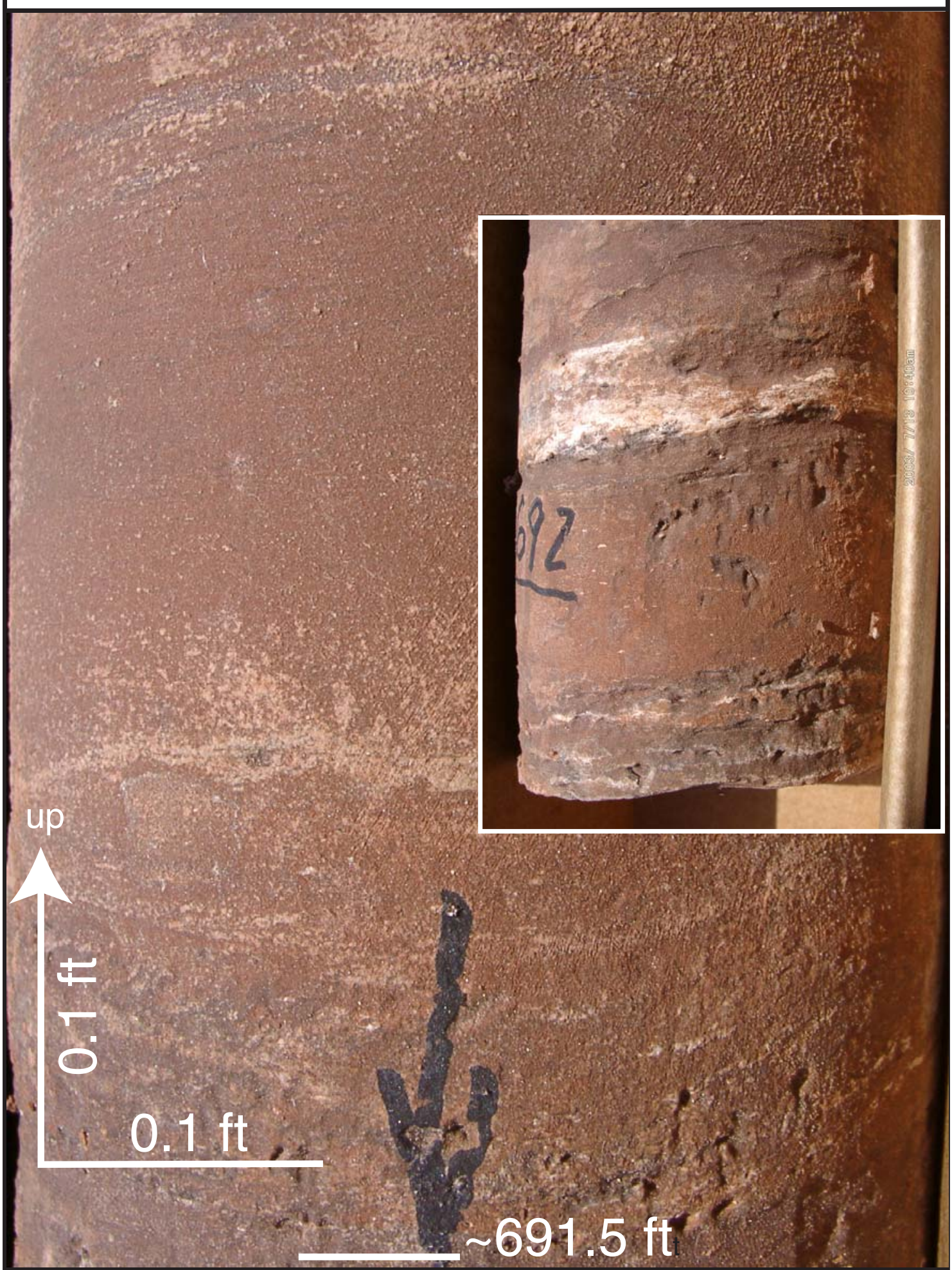


The unit is moderately indurated, and is likely cemented by gypsum near the base. Near-vertical fractures occur in the interval from $684-682 \mathrm{ft}$; some horizontal washouts parallel bedding, but they may also indicate horizontal separations. Holt and Powers (1988) and Powers and Holt (1999) also informally described this portion of the Los Medaños as the bioturbated clastic interval.

The interval from $\sim 679-673 \mathrm{ft}$ is dark gray (5Y4/1), very fine sandstone that is silty and argillaceous. Bedding is faint in thin zones ( $2-4$ inches thick), and other thin beds ( $2-4$ inches) included very thin laminae and some cross-bedding. This interval has poor to moderate induration. Fractures are approximately vertical and unfilled. Small pores ( $<0.5$ inches diameter) are washed out, and they may indicate bioturbation. Some bedding planes are also partially washed out.

The core from $673-658 \mathrm{ft}$ is believed to have been lost as the lower part of core run 8 and upper part of core run 9. The area of core loss is uncertain.

The interval from 658-644 ft is gray to dark gray (5Y5/1-4/1) argillaceous siltstone that is also slightly calcareous. Laminae are common, $\sim 0.04-0.08$ inch thick, some in sets to $0.2 \mathrm{ft}$ thick, and as low angle near-planar crossbedding (see 650.2-650 ft). From 657-652 ft, unfilled fractures range from nearly vertical to $45^{\circ}$ from vertical. There are short washout sections with similar orientations. Small nodules of gypsum (0.125-0.25 inch) are scattered throughout, and there are irregular vugs to $\sim 1$ inch diameter.

Dark grayish brown (2.5YR4/2), sandy siltstone from $644-638 \mathrm{ft}$ is not calcareous. It includes thin laminae ( $~ 0.04 \mathrm{inch})$ and some slight mottling in zones with poor bedding, possibly indicating bioturbation. This interval probably correlates with the transitional zone as assigned in Holt and Powers (1988); all of the lower Rustler here is included in $\mathrm{M}-1 / \mathrm{H}-1$ when trying to compare thickness changes in the WIPP area due to dissolution of halite in the lower Rustler.

A thin, anhydrite-cemented, gray sandstone from $638-637.1 \mathrm{ft}$ caps this section of clastic beds.
A thin, light brown sandy anhydrite occurs from 637.1-636.2 ft. This bed would be consistent with the upper part of the transition zone, as generally indicated by color changes, but it also correlates with sulfatic zones in the middle of the transition zone.

From 636.2-634.3 ft, a dark reddish brown (5YR3/4), silty, argillaceous sandstone includes possible claystone clasts, some poorly defined beds, and laminae at the top.

An anhydrite-cemented sandstone, from $634.3-633.7 \mathrm{ft}$, is somewhat similar to the sandy anhydrite from $637.1-636.2 \mathrm{ft}$.

A dark reddish brown (5YR3/4) argillaceous, silty sandstone from $633.7-627.9 \mathrm{ft}$ generally has poorly defined bedding, some possible claystone clasts, and laminae at the top of the bed.

The gray (5Y5/1) anhydrite from $627.9-624.8 \mathrm{ft}$ is recognizable in cores, shafts, and many geophysical logs across the WIPP site area (e.g., Powers and Richardson, in review). The anhydrite displays thin laminae, possible tiny vertically oriented (swallowtail) gypsum in the lower part, a probable growth ridge created by expansive gypsum crystal growth while the unit was subaerially exposed, and possible nodules in the upper part of the bed. The upper contact is irregular.

The reddish brown (5YR4/4), silty, argillaceous sandstone and dark reddish brown (5YR3/4), silty, sandy claystone from $624.8-620 \mathrm{ft}$ likely represent the interval immediately below A-1, although it was assigned below a core loss interval based on best field observations. Geophysical logs show that the anhydrite from $627.9-624.8 \mathrm{ft}$ is approximately $5 \mathrm{ft}$ below A-1 (Fig. 2-1). The claystone at the base displays subhorizontal mottled zones and gray layers. It includes probable smeared intraclast textures (Powers and Holt, 2000). The overlying sandstone exhibits thin laminae, some slight crosscutting bedding, and deformation. It is sulfatic, but it is poorly indurated. A very thin claystone was included at the base of core run 6, just below A-1, from 610-609.8 ft.

$\mathrm{M}-1 / \mathrm{H}-1$ is generally not well-cemented, and there was significant core loss. There is some 
probable gypsum cement near the base, overlying the Salado. Some sulfate cements are indicated in the zone with anhydrite beds, from 638-633.7 ft. The only zone with indications of carbonate cement is from 658-644 ft. No halite was observed anwhere in the lower Rustler. No fractures were observed to have a crystalline filling.

The informal unit anhydrite 1 (A-1; Fig. 2-4) (Holt and Powers, 1988) was encountered from 609-600 ft, based on the natural gamma and caliper logs from SNL-12 (Figs. 2-4, 3-1). Based on the drilling records, the core of A-1 was marked from $609.8-599.3 \mathrm{ft}$. The sedimentology of A-1 is discussed according to core depth markings.

A-1 at SNL-12 is expressed as three subunits: an anhydrite, a thin claystone, and a thin upper gypsum.

The anhydrite from $609.8-601 \mathrm{ft}$ is gray, with a slightly pink area at $609 \mathrm{ft}$. The pinkish color may indicate an earlier polyhalite or polyhalitic zone that has been diagenetically alterred. Vertical-growth gypsum occurs near the base, and the unit overall displays interbedded laminae and nodular beds on a scale of $\sim 0.5-1 \mathrm{ft}$.

The claystone from $600.5-600 \mathrm{ft}$ is silty, mainly reddish brown, and has some blebs of gypsum in the lower part.

At the top of A-1, white, nodular gypsum from 600-599.3 ft includes claystone that has infiltrated the unit from the overlying bed.

The informal unit mudstone-halite 2 (M-2/H-2; Fig. 2-4) (Holt and Powers, 1988) was encountered from $600-587 \mathrm{ft}$, based on the natural gamma and caliper logs from SNL-12 (Figs. 2-4, 3-1). The core from $\mathrm{M}-2 / \mathrm{H}-2$ was marked from $599.3-588.8 \mathrm{ft}$, according to the drilling data available. The unit was cored in one run, with all of the unit apparently recovered. The differences between core interval and log interval are not significant, with modest uncertainties for each. The unit is discussed according to core depth markings.

$\mathrm{M}-2 / \mathrm{H}-2$ at SNL-2 is mainly argillaceous siltstone with a thin, silty, dark gray (2.5YRN4) claystone (marked 589.6-588.8 ft) at the top.
Bedding is discernible but intermittent, ranging from laminae to thin beds. Bedding also can be horizontal (Fig. 2-6), as observed near the top of the M-2, mixed with zones showing some tilting of beds. $\mathrm{M}-2 / \mathrm{H}-2$ is mainly gray from the claystone down to $\sim 593.4 \mathrm{ft}$ and is reddish brown below that point. There are gypsiferous zones and displacive gypsum in the reddish brown zone and a horizontal gypsum vein with vertical fibers separating the color zones. $\mathrm{M}-2 / \mathrm{H}-2$ is blocky, and slickensides are common. The slickensides on different faces of block show differing directions. The upper contact with the overlying Culebra Dolomite Member appears sharp.

\subsubsection{Culebra Dolomite Member}

Based on the natural gamma log from SNL-12, the Culebra extends from $587-547 \mathrm{ft}$, while the core has been marked from 588.8-548.1 ft. Recovered Culebra core (Fig. 2-7) totals $\sim 40.7 \mathrm{ft}$ thick, and it is believed that the Culebra coring was complete, although portions of the core were rocovered as small blocks. This contrasts with common loss of core from the more permeable middle and lower sections of the Culebra.

Holt and Powers (1988) found a range of 20-30-ft thickness in Culebra cores described from WIPP and a regional thickness exceeding $40 \mathrm{ft}$, based on geophysical log data. The Culebra at SNL-12 is near the maximum determined regionally.

At SNL-12, the lower Culebra (588.8-577 ft) is light gray (5YR7/1) to gray (5Y6/1) dolomite with numerous pores and some thin bedding and flat laminae. From 588.8-586.2 ft, the pores are few, small, and filled with gypsum. From 586.2-584.3 ft, the vugs are small to large and are mainly filled with gypsum. From $584.3-577 \mathrm{ft}$, porosity is estimated to be $\sim 20 \%$, pores are as large as $\sim 0.5$ inch, and $\sim 1-2 \%$ are filled except in the zone from $582-579 \mathrm{ft}$. In that zone, an estimated $15-20 \%$ of the pores are filled. Horizontal fractures with black organic surfaces occur at $0.5-1 \mathrm{ft}$ spacing from 584-577 ft. 
The upper Culebra (577-548.1 ft) at SNL-12 generally ranges from very pale brown (10YR7/3) to pale brown (10YR6/3). It is silty dolomite, and may be gypsiferous. The upper Culebra includes scattered larger pores, to $\sim 0.5$ inch diameter, and vertical to subvertical fractures from $577-569.8 \mathrm{ft}$. From 569.8-569 ft, there are a few large pores. From 569-563.5 ft, pores are small, and some of the pores appear flattened. From 563.5-554.5 ft, the Culebra appears to have small öolites, large vugs, and rare subvertical fractures. From 553.5-551 ft, the Culebra has large pores. The uppermost Culebra is thin bedded to laminar, with stromatolites from 550-549.8 ft.

The Culebra core at SNL-12 differs from most of the other cores and shafts in thickness and presence of öolites. The macroscopic elements of the core indicate that the Culebra at SNL-12 corresponds generally to the hydrostratigraphic units, which are based on evidence from the cores at the H-19 multi-well complex (Holt, 1997).

The lowest hydrostratigraphic unit, CU-4, is assigned to the interval from 588.8-586.2 ft. This segment displays thin beds and laminae, and it has much less obvious porosity compared to overlying cores. It also is not a packbreccia, as is common in the vicinity of WIPP (e.g., Holt and Powers, 1988).

Hydrostratigraphic unit CU-3 is assigned to the interval from 586.2-569.8 ft. This interval is both fractured and very porous. It is expected to be the most permeable section of the Culebra at SNL-12.

Hydrostratigraphic unit CU-2 is the most problematic to assign because of the presence of öolites, which have not been identified near the WIPP site but have been reported from the Culebra elsewhere. In the absence of specific information about the hydraulic properties of the öolitic section, we assume that it has a permeability that is higher than the overlying, uppermost Culebra. The porous Culebra from 569.8-563.5 ft, and the öolitic segment from $563.5-553.5 \mathrm{ft}$, are both assigned to CU-2. Combined with CU-3, this section provides a thick interval $(32.7 \mathrm{ft})$ that likely provides relatively high transmissivity.

\section{Figure 2-6 \\ Bedding in Upper M-2 at SNL-12}

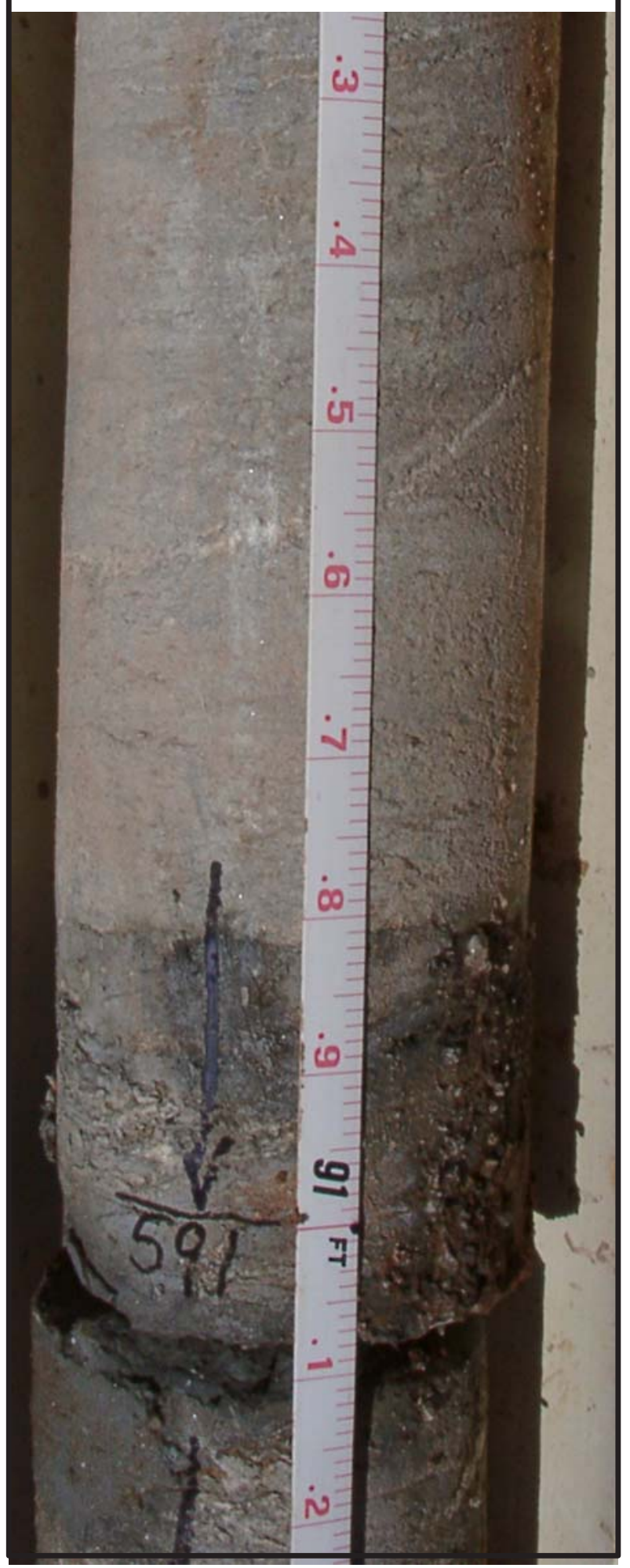


Hydrostratigraphic unit CU-1, with bedding and little conspicuous porosity, is assigned to the interval from $553.5-548.1 \mathrm{ft}$.

The geophysical logs of the Culebra from SNL-12 provide some additional details of the unit. The natural gamma log is low through the lower, gray-colored section of the Culebra below about $577 \mathrm{ft}$. The lower brown-colored dolomite from 577-563 ft shows variable natural gamma, with some higher zones consistent with more clay or organic matter. Above $563 \mathrm{ft}$, through the öolitic segment and overlying uppermost Culebra, natural gamma is low and decreases upward, indicating little clay or organic matter. The SNL-12 natural gamma log does not display features common to the Culebra nearer the WIPP site: a slight "spike" and upward sharp drop. The transition upward to gypsum of the Tamarisk was not as sharp or distinctive as in some other areas. The general low natural gamma through this interval is consistent with öolite deposition; öolites form in energetic shallowwater marine environments influenced by waves and tides that tend to remove fines. Some well logs in the vicinity of SNL-12 are similar, indicating öolitic beds are more widely distributed.

The microresistivity log shows three zones through the Culebra (Fig. 3-1). Resistivity is generally low, with a higher resistivity zone from 572-560 ft, corresponding to the brownish dolomite below the öolite zone. Given the evidence of porosity through this zone, the higher resistivity may be showing zonation to the fluid salinity, with lower salinity (higher resistivity) water through this zone. Resistivity measured deeper in the formation is similar in trend, but is not as distinctive.

The neutron log through the drillhole may not be reliable. It consistently shows signatures that indicate a 4-ft offset deeper than other log indicators. In addition, the neutron log shows neutron zones through the Culebra that correspond to the resistivity zone, if adjusted $4 \mathrm{ft}$ upward. Nevertheless, there is little difference in neutron through the Culebra and little difference between Culebra and other units above and below.
Fluid resistivity shows slight variations through the Culebra. Fluid temperature does not vary significantly through the Culebra. Neither adds to the information available from other logs.

\subsubsection{Tamarisk Member}

The natural gamma log of SNL-12 shows that the Tamarisk Member occurs from 547-460 ft bgl. The Tamarisk comprises three basic subunits: a lower anhydrite, a middle mudstone to halite, and an upper anhydrite; all three are clearly shown by geophysical logs and were recorded by core and cuttings during drilling. Powers and Holt (2000) labeled these A-2, M-2/H-2, and A-3, respectively, and showed that the lateral gradation from mudstone $\mathrm{M}-2$ to halite $\mathrm{H}-2$ reflects lateral changes in deposition. SNL-12 is located in the mudflat or M-2 facies of these beds. The basal $28.1 \mathrm{ft}$ and upper $10.2 \mathrm{ft}$ of the Tamarisk were cored; the remainder of the unit is described on the basis of cuttings and geophysical logs.

The informal unit anhydrite 2 (A-2; Fig. 2-4) (Holt and Powers, 1988) at the base of the Tamarisk is $11 \mathrm{ft}$ thick (547-536 ft bgl) on the geophysical logs. Core retained from the interval was marked from 548.1-536.7 ft, an interval thickness of $11.4 \mathrm{ft}$. A-2 is predominantly gray gypsum, but some anhydrite is also present.

The contact between the Culebra and A-2 is transitional over about $0.2 \mathrm{ft}$. Above the contact with the Culebra (Fig. 2-7), A-2 has laminar bedding. Thin beds and laminae of carbonate are dispersed through much of the unit. Some of the bedding is crinkly, possibly from deposition over tiny vertically oriented gypsum crystals. A clay and organic layer occurs at about $540.4 \mathrm{ft}$. Possible nodules of gypsum occur between $539.5-537 \mathrm{ft}$. A stylolite is present at $545.3 \mathrm{ft}$. The upper boundary of A-2 with the overlying claystone is sharp.

The informal Tamarisk unit mudstone-halite 3 (M-3/H-3; Fig. 2-4) (Holt and Powers, 1988) is $12 \mathrm{ft}$ thick (536-524 ft bgl) at SNL-12, based on the geophysical logs. The cored interval marked from 536.7-525.6 ft corresponds to the logged 


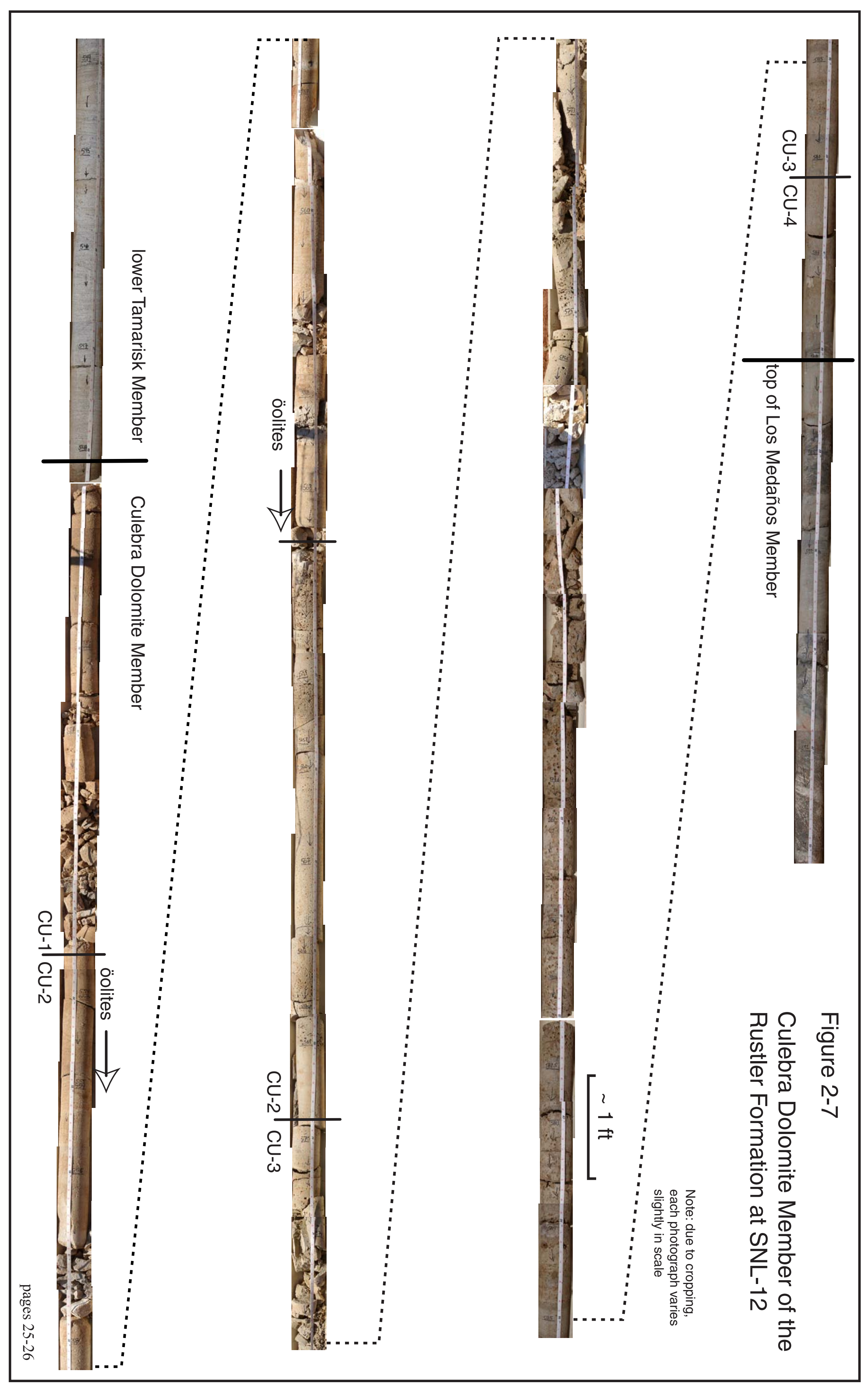


interval, and the thicknesses are consistent within the limits of interpreting the logs.

From 536.7-529 ft, M-2/H-2 is reddish brown (2.5YR4/4) claystone with a few gray zones. It is bedded in the lower $3.7 \mathrm{ft}$, and it includes possible smeared intraclast textures and some gypsum clasts. Above this zone, gypsum occurs boths as clasts and as fillings along bedding planes. From $529-525.6 \mathrm{ft}$, the claystone is mainly dark gray. The gray zone displays bedding that is disrupted in some zones. Gypsum decreases upward; it mainly occurs along bedding planes in the lower part and as clasts or intraclasts in the upper part.

The informal unit anhydrite 3 (A-3; Fig. 2-4) (Holt and Powers, 1988) occurs from 524-460 ft on geophysical logs, a thickness of $64 \mathrm{ft}$. Core markings for the base and top, respectively, for this unit are $525.6 \mathrm{ft}$ and $460.3 \mathrm{ft}$, for an inferred thickness of approximately $65.2 \mathrm{ft}$. The upper and lower contacts were cored. The main part of the unit was drilled, and cuttings were retained from some of the interval (Appendix C, sheet 5).

About $5.6 \mathrm{ft}$ of the basal A-3 was cored, and this part of the unit is dark gray anhydrite and gypsum. The core is bedded and may include some small gypsum nodules. Crystal sizes range from fine to coarse.

The drilled portion of A-3 produced mostly very fine powder; some coarser cuttings showed gray gypsum and anhydrite. Geophysical logs indicate a normal stratigraphic section through the drilled portion.

About $10.2 \mathrm{ft}$ of the uppermost A-3 was cored. From $470.5-461 \mathrm{ft}$, the core is gray gypsum and anhydrite that are fine to coarsely crystalline. The core displays poorly defined laminar bedding and possible small nodules through this interval. From $461-460.3 \mathrm{ft}, \mathrm{A}-3$ consists of gray gypsum, fine to coarse crystals, and irregular thin laminae of brown carbonate that indicate algal growth (Fig. 2-7). This zone is attributed to the Tamarisk, but it is indicating the transition from sulfate to carbonate deposition leading to the Magenta Dolomite.
The Tamarisk stratigraphy and thickness are consistent with other drillholes and shafts in the area (Holt and Powers, 1988).

\subsubsection{Magenta Dolomite Member}

The Magenta Dolomite Member at SNL-12 is $28 \mathrm{ft}$ thick (460-432 ft ) based on geophysical logs. Core from the Magenta is marked from 460.3-432.9 ft, a thickness of about $27.4 \mathrm{ft}$ (Fig. 2-7). The entire unit was cored; recovery was good, and the core quality was good.

The Magenta consists of sandy to granular dolomite and gypsum, and it is white (10Y8/2) to gray $(10 \mathrm{Y} 5 / 1)$ in core. The reddish-purple color for which the Magenta is named occurs in outcrop and apparently is a consequence of weathering. The dominant characteristic of the Magenta in cores from SNL-12, like outcrops and shaft exposures of the Magenta, is strong wavy to laminar bedding, with some ripples. Wave amplitudes commonly decrease upward from the base of the Magenta. In the lower Magenta, amplitudes range from about $0.1-0.2 \mathrm{ft}$ (Figure 3-7). Bedding amplitude is more commonly about $0.25-0.5$ inch in the middle and upper part of the Magenta. Some small ripple bedding is evident in the Magenta. Near the base of the Magenta at SNL-12, the wavy bedding and ripples are draped by very thin, dark laminae that are interpreted as stromatolitic. This is consistent with well-exposed algal features in the air intake shaft (Holt and Powers, 1990a; Powers and Holt, 1990), but there were no larger stromatolites in the core. In the zone from $\sim 437.3-436.8 \mathrm{ft}$, some of the grains appear to be öolites, associated with ripples.

The Magenta shows little evidence of fracturing. A high-angle fracture from about $450-449 \mathrm{ft}$ is filled with gypsum. Some bedding planes, even on wavy bedding, in the lower few ft of the Magenta core have fibrous gypsum filling slight separations.

The core of the Magenta from SNL-12 does not show surface evidence of open porosity or porosity zones. The microresistivity log shows lower resistivity through 448-435 ft, corresponding to the gray (brownish) zone of the Magenta that includes more granular and possible öolitic rock. The neutron 


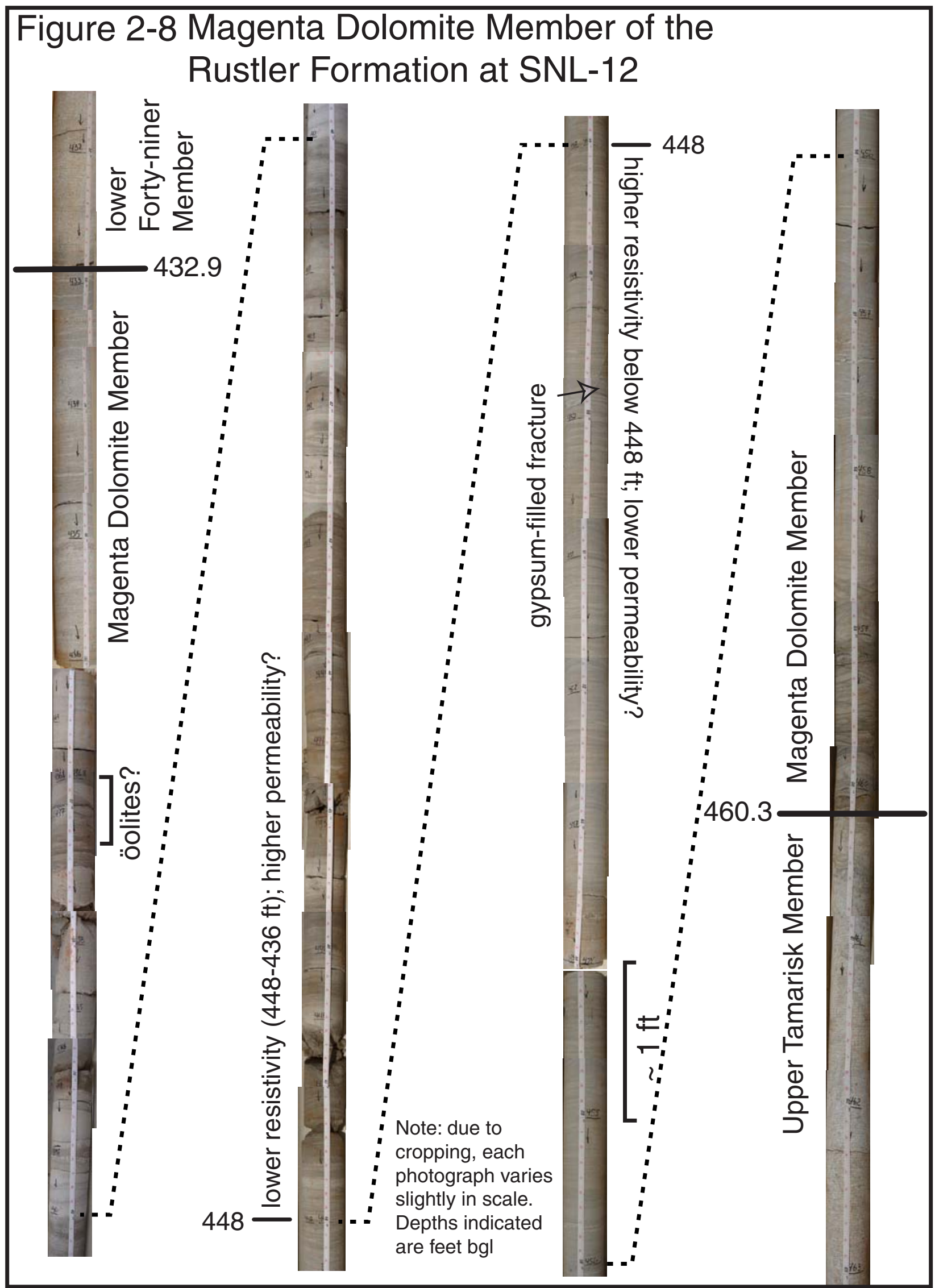


$\log$ shows an increase through this zone, if a 4- $\mathrm{ft}$ offset is assumed as discussed regarding Culebra logs. The contrast for the resistivity log is with overlying gypsum and more gypsiferous zones below. These zones apparently have little porosity, increasing the resistivity. The neutron contrast (higher neutron in a more porous zone) would be consistent with low porosity, where the water content is volumetrically less than that in adjacent gypsum (increasing the relative neutron count).

The upper contact of the Magenta with the overlying Forty-niner Member, as placed on the core, is sharp. The depositional transition was not sharp, however, as gypsum is interbedded with dolomite through the upper $3 \mathrm{ft}$ of the Magenta before dolomite becomes insignificant.

The Magenta is similar in thickness, composition, and bedding characteristics to most of the Magenta described around the WIPP site. Algal features are not as prominent as in some other cores, and ripples are better expressed. If öolites are confirmed to be present, they would be a new feature for the Magenta. The Magenta is little fractured at SNL-12, contrasting with some other cores (e.g., SNL-2; Powers and Richardson, in review). Based on the resistivity logs, the more porous part of the Magenta is $\sim 12 \mathrm{ft}$ thick and is located in the upper half of the Magenta. This is similar to findings from other recent drillholes (e.g., Powers, 2002b; Powers and Richardson, in review).

\subsubsection{Forty-niner Member}

The Forty-niner Member at SNL-12 is $60 \mathrm{ft}$ thick (432-372 ft), based on geophysical logs. A change in drilling rates was noted at a depth of $\sim 374$ $\mathrm{ft}$, consistent with the logging depths. The Forty-niner is described on the basis of cuttings and geophysical logs through the upper part of the member to the coring depth beginning at $425 \mathrm{ft}$. All Forty-niner coring took place in the lower sulfate beds of the member. Like the Tamarisk, the Forty-niner consists of upper and lower anhydrites with a middle unit that ranges from siltstone and claystone at SNL-12 to halite east of the WIPP site area. Powers and Holt (2000) informally designated these units as A-4, M-4/H-4, and A-5, from bottom to top, and they attributed the lateral relationship between clastic beds (M-4) and halite $(\mathrm{H}-4)$ to depositional facies of mudflat-saline mudflat-saltpan environments.

The lower unit, anhydrite 4 (A-4; Fig. 2-4) (Holt and Powers, 1988), is gray to white gypsum and anhydrite ranging from very coarse gypsum to finer anhydrite. A-4 is $14 \mathrm{ft}$ thick, based on geophysical logs; drilling and coring indicated a thickness of $14.9 \mathrm{ft}$. The recovered core of A-4 $(432.9-425 \mathrm{ft})$ reveals thin laminae separating beds and thin zones $(<0.5$ inch) with wavy brown laminae that are probably algal. Some of the beds appear nodular. As noted in the discussion of the Magenta, the environmental transition was not abrupt in this location. Above the cored interval, cuttings from A-4 were composed of white to gray gypsum ranging from fine, sugary crystals to coarser flakes.

Mudstone-halite 4 (M-4/H-4; Fig. 2-4) (Holt and Powers, 1988) is $\sim 15 \mathrm{ft}$ thick (418-403 ft ), based on the natural gamma log. Cuttings from M-4 revealed distinct beds within the unit. From 418-410 ft, cuttings consisted of dark gray (2.5YRN4, wet), argillaceous, sandy siltstone. It is gypsiferous and not calcareous. Cuttings indicated thin fractures filled with gypsum. From 410-405 ft, cuttings consisted of dark reddish brown (5YR3/4, wet), sandy, silty claystone that is not calcareous. Some gypsum may be present. These units are typical of M-4 (Holt and Powers, 1988), but they are not always distinguished in cuttings.

The upper sulfate unit, anhydrite-5 (A-5), is $\sim 31 \mathrm{ft}$ thick (403-372 $\mathrm{ft}$ ) at SNL-12, based on geophysical logs. The interval indicated during drilling is also $31 \mathrm{ft}$, though the depths differ slightly (405-374 ft). Cuttings from A-5 in SNL-12 were mainly white to very pale brown (10YR8/3) and dark grayish brown (10YR4/2) gypsum and anhydrite. Most of the anhydrite is finer and darker. A slight gamma peak at $388 \mathrm{ft}$ is similar to modest increases noted by Holt and Powers (1988) in the area east of SNL-12 and is attributed to a slight 
increase in clay or carbonate content. The thin halite found in A-5 east of SNL-12 is not present here.

\subsubsection{Permo-Triassic Dewey Lake Formation}

The Dewey Lake Formation has most commonly been assigned to the Permian System (e.g., Hills and Kottlowski, 1983), although there is no direct evidence, either paleontological or radiometric, of age in the vicinity of WIPP. More recently, Renne and others $(1996,2001)$ obtained radiometric (Ar-Ar) ages from ash beds near the base of lithologically equivalent red beds (Quartermaster Formation) in the Texas panhandle. These ages show that the basal Quartermaster is Permian, but most of the formation is early Triassic in age. Although lithologic contacts are not inherently isochronous, the particular relationships of evaporites to red beds suggest that the Dewey Lake is mainly Triassic in age (e.g., Schiel, 1988, 1994; Powers and Holt, 1999). Lucas and Anderson (1993) have asserted that the Quartermaster, and Dewey Lake, are Permian in age, but more recent direct evidence supersedes their discussion.

At SNL-12, the Dewey Lake is $336 \mathrm{ft}$ thick (372-36 ft ), based on geophysical logs. During drilling, cuttings clearly identifiable as Dewey Lake were not returned to the surface until a depth of $57 \mathrm{ft}$ (Appendix C, sheet 1). The Dewey Lake is composed mainly of red (2.5YR4/6-5/6) or reddish brown (5YR5/4) siltstone interbedded with claystone and fine to very fine sandstone. Small $(<0.04 \mathrm{inch})$, greenish gray reduction spots are a common characteristic of the Dewey Lake at SNL-12 and elsewhere. Dewey Lake cuttings are very calcareous to a depth of $\sim 175 \mathrm{ft}$; from $180 \mathrm{ft}$, cuttings are gypsiferous and slightly or not calcareous. Most of the Dewey Lake is described on the basis of cuttings, drilling rates, and geophysical log characteristics.

Geophysical logs from SNL-12 can be interpreted to indicate different basic sedimentary regimes as well as porosity conditions (e.g., Doveton, 1986). The following information follows the basic template developed for a study of the Dewey Lake hydrogeology (Powers, 2003b) and applied to other drillholes such as C-2737 (Powers, 2002b).

Only the lower two of three general depositional regimes for the Dewey Lake Formation can be distinguished on natural gamma logs of SNL-12, and the second is only partially preserved.

The interval from 372-240 ft in SNL-12 displays the natural gamma and resistivity features of the lower Dewey Lake informally called the basal bedded zone (Powers, 2003b). The natural gamma fluctuates around a similar value ( $25 \mathrm{cps}$ in this case) over this vertical interval, and there are no apparent trends over the entire interval. The resistivity tends to fluctuate as well, on a vertical scale of $\sim 4-25 \mathrm{ft}$. In the vicinity of the WIPP site, fluctuations appear to correlate across boreholes, suggesting broad scale bedding, and the interval corresponds to a bedded section clearly exposed in the air intake shaft (Holt and Powers, 1988). At SNL-12, the fluctuations are similar to the WIPP site area, but they have not individually been correlated with site area.

The interval from $240-36 \mathrm{ft}$ (204 ft thick) is marked by generally upward increasing gamma above thinner low gamma units. These are interpreted as an interval of fining upward cycles because increasing natural gamma is frequently an indicator of finer clastic grain sizes (Powers, 2003b). A sandstone unit from $\sim 240-224 \mathrm{ft}$ is at the base of this interval.

The interval of fining upward cycles is truncated at SNL-12 by erosion by the overlying unit. Near the center of the site, this interval is more than $300 \mathrm{ft}$ thick; at C-2737 it was $260 \mathrm{ft}$ thick (Powers, 2002b). At SNL-12, sandstones of the upper fining upward cycles are removed by erosion. Some smaller fining upward cycles are defined, but the trend over much of the interval appears to be mainly a broad fining upward.

The upper coarsening interval of the Dewey Lake at SNL-12 has been removed by erosion. The broad sedimentological units definable by 
natural gamma logs for the lower Dewey Lake are present and are generally representative below the erosional surface.

Cuttings from SNL-12 showed a downward change from carbonate cement to sulfate cements and fracture fillings at $\sim 180 \mathrm{ft}$. Resistivity logs also show a change in character at $\sim 180 \mathrm{ft}$, increasing somewhat below that point. The neutron log was unresponsive at this point. This cement change is observable in other cores from the area (Powers, 2002b, 2003b), and it was reported in the air intake shaft (Holt and Powers, 1988).

The carbonate-sulfate cement boundary in the range of $180 \mathrm{ft}$ is stratigraphically lower in SNL-12 than it is at the middle of the site at drillhole C-2737 (Powers, 2002b) or at the air intake shaft (Holt and Powers, 1990a). This change is consistent with the boundary dropping stratigraphically as the Dewey Lake is more exposed to erosion and weathering (Powers, 2003b), especially to the south of the WIPP site.

The saturated interval in the Dewey Lake (see chapter 3) was not determined; the drillhole depth was $175 \mathrm{ft}$ when the water level was allowed to stabilize. The cement change and resistivity change at $180 \mathrm{ft}$ are consistent with the proposal by Powers (2003b) that natural groundwater is perched on the less porous sulfate-cemented zone of the Dewey Lake.

\subsubsection{Miocene-Pleistocene Gatuña Formation}

Based on the cuttings from drilling and geophysical logs, the Gatuña occurs from 36-18 ft. Cuttings to a depth of $57 \mathrm{ft}$ were dominated by similar lithology. (The caliper log shows the drillhole diameter was enlarged through the upper part of the formation; this likely diluted cuttings sources for the short period the hole was being deepened through the uppermost Dewey Lake.) The Gatuña at SNL-12 is primarily light reddish-brown (5YR5/4-4/4) to red (2.5YR4/6-5/6) sandstone with interbedded argillaceous zones and argillaceous siltstone.
Gatuña sandstones are very calcareous, with calcite increasing vertically where pedogenic calcrete has infiltrated the unit. Sand grains from the lower Gatuña are fine to medium and include mica and other opaque grains. Sands from the upper Gatuña are very fine to fine, with some medium grains. They are subangular and are poor to medium sorted. $\mathrm{MnO}_{2}$ stains some of the cuttings, probably from pedogenic processes. Small $(<0.04$ inch) cylindrical bioturbation probably formed as root casts.

Gatuña depositional patterns are poorly known in the area of SNL-12. There are some outcrops to the west of SNL-12, and Gatuña increases in thickness to the southwest at Pierce Canyon (Powers and Holt, 1993). The Santa Rosa was eroded before Gatuña deposition, as was part of the upper Dewey Lake. Chert pebbles that populate some of the Gatuña where it overlies the Santa Rosa or is adjacent to the erosional edge of the Santa Rosa are missing.

The Gatuña ranges in age from at least 13.5 to $\sim 0.5$ million years old (Powers and Holt, 1993). SNL-12 is distant from an outcrop of Lava Creek B ash found at the top of the Gatuña by Bachman (Bachman, 1980; Izett and Wilcox, 1982) along Livingston Ridge. The Gatuña at SNL-12 does not provide any direct clues to its age, but it may represent younger portions of the unit range, as is believed the case for much of the upland Gatuña deposits.

\subsubsection{Pleistocene Mescalero Caliche}

The Mescalero is an informal soil stratigraphic unit defined by Bachman (1973). It is widespread in southeastern New Mexico, and it is a continuous stratigraphic unit at the WIPP site. Uraniumdisequilibrium ages indicate the Mescalero formed as a pedogenic unit between about 570,000 $( \pm 100,000)$ and about $420,000( \pm 60,000)$ years ago (Rosholt and McKinney, 1980). The age is further bounded by the Lava Creek B ash, about 600,000 years old, which underlies the Mescalero along Livingston Ridge (Izett and Wilcox, 1982). 
At SNL-12, the Mescalero is $\sim 8 \mathrm{ft}$ thick. Mescalero cuttings at SNL-12 provide little evidence of its origin. It ranges from very calcareous sandstone to sandy "limestone" that is pinkish white (2.5YR8/2). The sand grains are similar to the overlying dune sand.

The Mescalero shows evidence of pedogenic processes such as nodule, ped, and laminae development in exposures in the general area of SNL-12. Not only is the unit strongly calcareous, the upper portion of the unit is locally plugged and subhorizontal laminae are partially developed at the upper surface. Bachman and Machette (1977) classified six useful stages of pedogenic calcrete development, ranging from I as the least developed to VI morphologies showing multiple generations of calcrete development. ("Pedogenic calcrete" is preferred by many geologists and pedologists over the term "caliche" because of the wide variation in use of the latter term.) The Mescalero is generally at stage IV-V in the vicinity of SNL-12.

\subsubsection{Pleistocene Berino Soil and Surficial Sands}

The surficial sands and Berino are strong brown (7.5YR5/6) sand and sandstone that is friable at the surface and increasingly argillaceous with depth. There was no evidence of soil carbonate in either surficial sands or Berino soil. Sand grains are fine to very fine, subrounded, moderately well sorted, and are mostly quartz with a trace of opaque grains. At SNL-12, the cuttings felt slightly moist with depth. The Berino soil is not a geologic unit; it is a pedogenic unit defined by the soil scientists in the area (Chugg and others, 1971). The upper $2 \mathrm{ft}$ consisted of mixed sand and imported Mescalero caliche used to construct the drilling pad. 


\subsection{PRELIMINARY HYDROLOGICAL DATA FOR SNL-12}

SNL-12 was drilled specifically to monitor water levels and water quality from the Culebra Dolomite Member of the Rustler Formation and to serve as a location for a pumping test and observations during other pumping tests.

\subsection{Shallow Groundwater above the Rustler Formation}

Groundwater was encountered in the Dewey Lake Formation at SNL-12 on June 26, 2003. As the drillhole reached $\sim 160 \mathrm{ft}$ depth using compressed air, cuttings began to cake and felt moist. At a depth of $170 \mathrm{ft}$, the drilling was stopped for $\sim 10$ minutes and air was circulated without observable water in the return flow. The drillhole was deepened to $175 \mathrm{ft}$, and the hole was allowed to stand from 11:51 to 13:00 MDT without drilling or circulating air. At 13:00 MDT, the water level in the drillhole was $164.3 \mathrm{ft}$, an inflow filling 10.7 ft. Samples for analysis by Sandia National Laboratories were obtained with a small plastic bailer at 13:10 and 14:00 MDT. At 14:17 MDT, the water level was at $155 \mathrm{ft}$. To provide ample opportunity for the water level to stabilize, drilling was suspended until July 7, 2003. The water level was measured at $141.55 \mathrm{ft}$ at 12:19 MDT on July 7. Additional water samples were obtained on July 7 for analysis by Sandia National Laboratories. After sampling, the hole was drilled to deeper units using fresh water with Baroid Quik-Foam.

\subsection{Initial Results from the Magenta Dolomite}

During drilling of SNL-12, no specific evidence of water inflow, rates, or water levels for the Magenta Dolomite was obtained.

After the Magenta and upper Tamarisk were cored to $470.5 \mathrm{ft}$ on July 8, 2003, the drillhole remained open overnight. On July 9, 2003, an electric probe was lowered in the open drillhole and encountered water at $142.3 \mathrm{ft}$. This level is more than $300 \mathrm{ft}$ above the Magenta, and it is $\sim 13 \mathrm{ft}$ higher than the measured water level in the Dewey Lake on the previous day. Both Dewey Lake and Magenta were open to the drillhole.

On July 9, 2003, the drillhole was drilled and cored to a depth of $577 \mathrm{ft}$, which is $\sim 11 \mathrm{ft}$ above the base of the Culebra. On July 10, the water level was $143.5 \mathrm{ft}$, slightly less than the previous day, and the drillhole was open to $372.3 \mathrm{ft}$. Three intervals likely contributed to the water levels (Dewey Lake, Magenta, and Culebra), but the specifics are undetermined. From 577 ft, SNL-12 was drilled with brine and Flowzan.

\subsection{Initial Results From the Culebra Dolomite}

As indicated above, the combined fluid levels in SNL-12 on July 10, 2003, reached $143.5 \mathrm{ft}$, and the specific contribution of the Culebra was undetermined.

On August 4, 2003, a pump was placed in the casing to develop the Culebra hydrology and remove drilling fluids. Over a period of $\sim 3.5$ hours, the well was pumped during three intervals with two short backwash/surge periods (Appendix B). A total volume of 80 barrels of water were produced during well development, and the water was clear, with a field-measured fluid density of $1.020 \mathrm{~g} / \mathrm{cc}$ near the end of the pumping. During some initial pumping, rates were as low as $16 \mathrm{gpm}$ (gallons per minute); later stages of pumping were steady at $\sim 26.5 \mathrm{gpm}$.

From August 2003 through March 2004, static water levels for the Culebra in SNL-12 were regularly measured (Table 3-1). The casing elevation is 3,339.44 ft amsl (Fig. 2-5). The depth to water on March 8, 2004, was $342.41 \mathrm{ft}$, and the uncorrected water level elevation was $2,997.03 \mathrm{ft}$ amsl. The fresh-water equivalent (FWE) level, corrected for fluid density, was 3,001.57 ft amsl (Siegel, 2004) (Table 3-1; Fig. 3-1).

On April 5, 2004, the screen interval was jetted under pressure with about 150 barrels of clean water to remove sediment (Appendix B). An additional 2,526 gallons of water were pumped 
from the well at rates of approximately $14 \mathrm{gpm}$, and the removed water was very clear. The fluid density was measured in the field as $1.004 \mathrm{~g} / \mathrm{cc}$. Depth to water on April 13, 2004, was $340.50 \mathrm{ft}$, and the elevation was $2998.94 \mathrm{ft}$ amsl. The reported FWE head (2999.84 ft amsl; Seigel, 2004) was computed using the lower fluid density reported in April 2004. The change in fluid density affects the apparent changes in FWE levels in April (Fig. 3-1).

\subsection{Observations About the Rustler- Salado Contact}

The interval was cored with good recovery. There was no indication during drilling of changes in drilling fluid or of flow into the drillhole from this zone affecting the drilling fluid returns. Cores across the Rustler-Salado contact do not indicate postdepositional dissolution of the upper Salado, and this is consistent with little, if any, water at this zone.

\begin{tabular}{|c|c|c|c|c|}
\hline \multicolumn{7}{|c|}{ Culebra Water Levels Measured in SNL-12 } \\
\hline \multirow{2}{*}{ Date } & Time & Depth (ft) to & \multicolumn{2}{c|}{ Water Elevation (ft amsl) } \\
\cline { 4 - 6 } & (MDT) & water level & Measured & Fresh-water Equivalent* \\
\hline $08 / 14 / 03$ & $7: 05$ & 347.46 & 2991.98 & 2996.41 \\
\hline $09 / 09 / 03$ & $13: 04$ & 344.24 & 2995.20 & 2999.70 \\
\hline $10 / 07 / 03$ & $8: 04$ & 343.59 & 2995.85 & 3000.36 \\
\hline $11 / 03 / 03$ & $12: 45$ & 343.31 & 2996.13 & 3000.65 \\
\hline $12 / 09 / 03$ & $10: 14$ & 343.14 & 2996.30 & 3000.82 \\
\hline $01 / 12 / 04$ & $13: 45$ & 343.10 & 2996.34 & 3000.86 \\
\hline $02 / 09 / 04$ & $14: 12$ & 343.06 & 2996.38 & 3000.90 \\
\hline $03 / 08 / 04$ & $13: 40$ & 342.41 & 2997.03 & 3001.57 \\
\hline $04 / 13 / 04$ & $8: 12$ & 340.50 & 2998.94 & 2999.85 \\
\hline
\end{tabular}

*Fluid density used for determining fresh-water equivalent elevation is $1.020 \mathrm{~g} / \mathrm{cc}$ through March 2004; from April 2004, the fluid density is $1.004 \mathrm{~g} / \mathrm{cc}$.

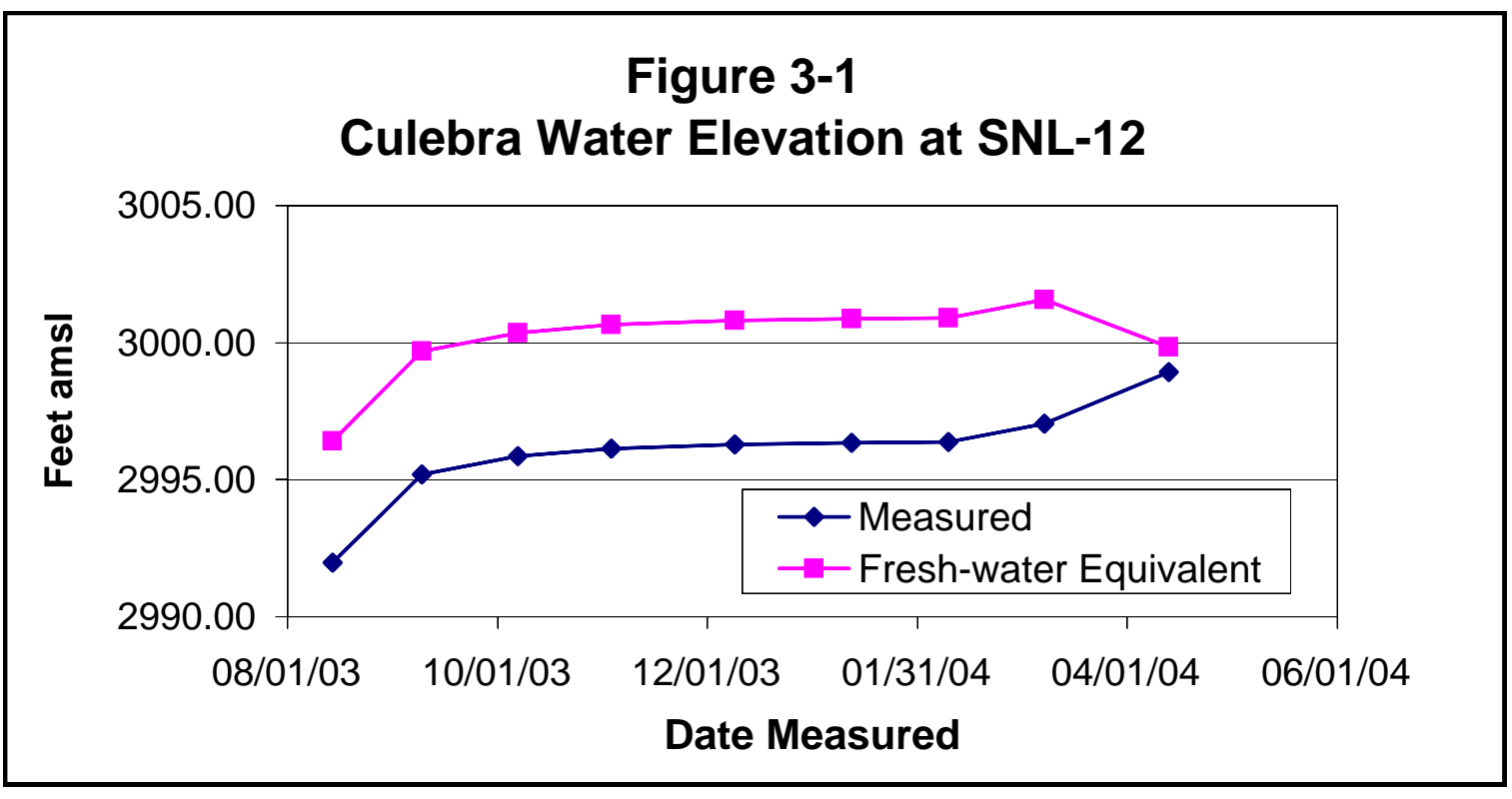




\subsection{SIGNIFICANCE/DISCUSSION}

The materials used in completing SNL-12 are expected to be stable over a lengthy monitoring period, in contrast to steel casing in monitoring wells drilled before 1995. Newer monitoring wells provide construction experience for groundwater surveillance wells that may be drilled in the future.

SNL-12 was located south of the WIPP site to accomplish several purposes (Sandia National Laboratories, 2003). It was located east of the apparent line of dissolution of upper Salado halite (Powers, 2002a, 2003a). The specific location was chosen in part to test the possibility of a dissolution reentrant. One nearby borehole indicated a slightly thinner interval between Culebra and Vaca Triste (Fig. 4-1), but there was neither marked thinning nor other indicators of increased Culebra transmissivity, such as existed for SNL-9 (Powers and Richardson, in prep.). SNL-12 was located near surface drainage in the event this feature reflected processes at depth.

The lower Rustler and uppermost Salado were cored to obtain direct evidence bearing on the status of dissolution of halite in the uppermost Salado in this vicinity (Fig. 4-1). In the area south of WIPP and east of the southeastern arm of Nash Draw, Powers (2002a, 2003a), Holt and Powers (2002), and Powers and others (2003) showed a marked decrease in the thickness of the interval between the Vaca Triste Sandstone Member of the Salado Formation and the top of the Culebra Dolomite Member of the Rustler Formation (Fig. 4-1). Geophysical logs supplied data that indicated the change in thickness occurred because of dissolution of halite at the top of the Salado and that also indicated the SNL-12 location would be little, if any, affected by this process. Holt (2002) and Powers and others (2003) related this margin to significant changes in the hydraulic properties of the Culebra.

Upper Salado halite with clastics includes halite with displacive margins, an indicator of deposition and an indicator that these are not residues after postdepositional dissolution.

Macroscopic features of the cores across the boundary reveal thicker sulfate at the boundary that may be a unit amalgamated by syndepositional processes, possibly involving slight dissolution as well as repeated mudflat to gypsum mud flat fluctuations. Although upper Salado halite has been dissolved in other areas to accumulate sulfate beds as a residue, the overlying cores of the basal Rustler show excellent preservation of fine bedding and thin laminae without evidence of distortion or fracturing that would be expected to accompany postdepositional dissolution of halite. At SNL-12, the macroscopic features indicate that upper Salado halite has not been removed after the Rustler was deposited. This confirms the predrilling expectations for the location.

Much of the lower Los Medaños in M-1/H-1 does not show mineral cements. There is some gypsum cement of sandstones near the thin sulfate beds below A-1. The gypsum beds and cement at SNL-12 in this stratigraphic position are more prominent than in the vicinity of WIPP, although there are generally equivalent units.

Halite beds (H-1) for the lower Los Medaños are stratigraphically equivalent to the upper M-1 beds and sulfatic beds below A-1. At SNL-12, cores from this interval are relatively complete, but macroscopic features are not well displayed. Some smeared intraclast textures may occur below A-1, in a stratigraphic interval that also shows some bedding. There is no evidence of postdepositional dissolution of halite from these features, but more detailed study of the cores is appropriate.

The M-2 interval below the Culebra is well sampled and typical of the unit. Bedding and color stratification are consistent with not having halite removed from this unit after deposition.

Culebra core recovery was very good, including zones that commonly are not retained during coring. The Culebra is unusually thick at SNL-12, and it includes a zone of probable öolites $\sim 10 \mathrm{ft}$ thick that account for much of the increased thickness. Although öolites have been reported previously for the Culebra, they have not been identified as a significant part of the unit in the vicinity of WIPP. The main significance to the Culebra at SNL-12 is that this zone likely has 
relatively high transmissivity and increases the thickness of hydrostratigraphic units CU-2 and CU-3, which are normally the most transmissive units of the Culebra. CU-3 typcially has very large pores or vugs and fractures creating high transmissivity. At SNL-12, the vugs do not appear as concentrated as they are in the same zone in drillholes nearer WIPP. The fractured zone appears shorter and less extensive at SNL-12 compared to some drillholes nearer WIPP. The combined zones of CU-3 and CU-2 likely represent a thicker zone (compared to other drillholes nearer WIPP) of higher transmissivity, but fewer vugs and a less extensive fracture zone may mean the overall transmissivity of the Culebra is less at SNL-12 than might be expected. Although no hydraulic testing has been conducted at the time of this report, it is likely that the zone including CU-2 and CU-3 is the most transmissive for the SNL-12 location by analogy to past experience.

Field testing of fluid density of Culebra water suggests that total dissolved solids will be low relative to measurements of Culebra water nearer the WIPP site center.

Cores from M-3 at SNL-12 showed the basic color, lithologic distinctions, and sedimentary features common to this unit at the WIPP site. Clasts or intraclasts suggest subaerial exposure during deposition, consistent with interpretations elsewhere. Halite is not believed to have been a significant part of this unit at SNL-12 and was not dissolved after deposition.

The Magenta core showed little surface porosity or variation during logging that suggest a highly transmissive zone. The microresistivity log suggests that a zone $\sim 12 \mathrm{ft}$ thick in the upper Magenta is more porous than the rest of the member. This pattern has been observed in several wells (e.g., C-2737, Powers, 2002b; SNL-2, Powers and Richardson, in review). The Magenta shows only one clear fracture, and that fracture is filled with gypsum. Water levels observed during drilling provide no information on whether the Magenta produced water at SNL-12.
Cuttings from M-4 at SNL-12 revealed the color and lithologic changes that are typical of the unit closer to the WIPP site. By analogy, there is not believed to have been any halite removed from M-4/H-4 at SNL-12 after deposition.

Cuttings and resistivity changes suggest that the change in natural mineral cements of the Dewey Lake is $\sim 180 \mathrm{ft}$, and this is consistent with a broad trend for this boundary to be stratigraphically low west and south of the WIPP site center and stratigraphically higher in the center and eastern part of the site (Powers, 2003b). In the southern part of the site, Powers (2003b) hypothesized that this cement boundary provides a perching horizon for natural groundwater. Although the lower boundary of the saturated zone in SNL-12 has not been established, the saturated zone encountered in SNL-12 is consistent with this hypothesis. The stratigraphic position of the cement boundary is much higher near the WIPP site center (e.g., Holt and Powers, 1990a; Powers, 1997, 2002b, 2003b); some of the Dewey Lake has been removed by erosion at SNL-12.

The saturated zone in the Dewey Lake was not tested to determine hydraulic properties. The water quality is good, as indicated by field measurements of fluid density of $0.999 \mathrm{~g} / \mathrm{cc}$. 


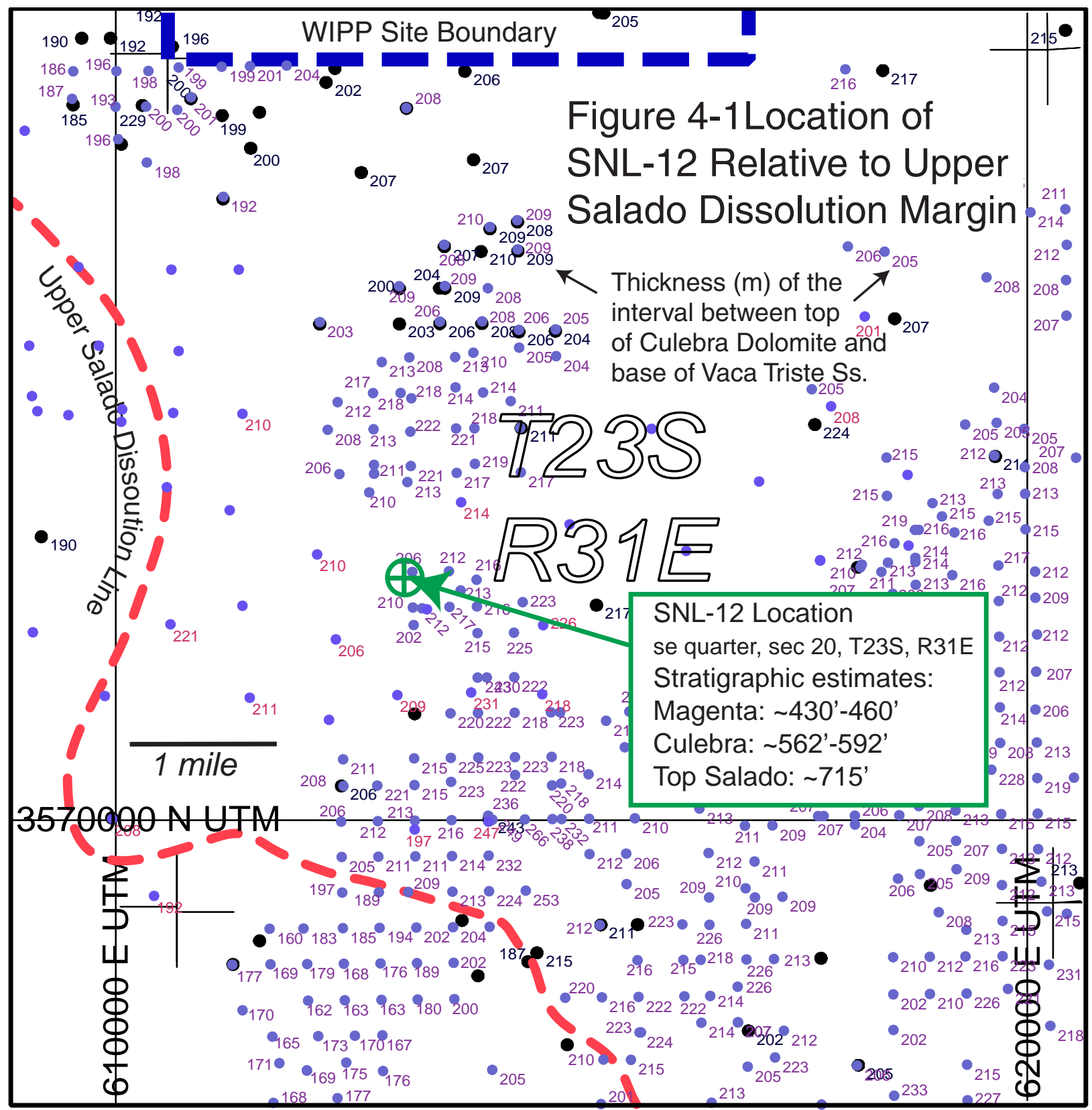

Modified from Powers (2003b). 
Basic Data Report for Drillhole SNL-12 (C-2954)

DOE/WIPP 03-3295

This page is intentionally left blank. 


\subsection{REFERENCES CITED}

Bachman, G.O., 1973, Surficial Features and Late Cenozoic History in Southeastern New Mexico: U.S. Geological Survey Open-file Report USGS-4339-8, 32 p.

Bachman, G.O., 1980, Regional Geology and Cenozoic History of Pecos Region, Southeastern New Mexico: U.S. Geological Survey Open-file Report 80-1099, $116 \mathrm{p}$.

Bachman, G.O., 1985, Assessment of Near-surface Dissolution at and Near the Waste Isolation Pilot Plant (WIPP), Southeastern New Mexico: SAND84-7178, Sandia National Laboratories, Albuquerque, NM.

Bachman, G.O., and Machette, M.N., 1977, Calcic Soils and Calcretes in the Southwestern United States: U.S. Geological Survey Open-file Report 77-794, 163 p.

Chugg, J.C., Anderson, G.W., Kink, D.L., and Jones, L.H., 1971, Soil Survey of Eddy Area, New Mexico: U.S. Department of Agriculture, $82 \mathrm{p}$ plus figures.

Doveton, J.H., 1986, Log Analysis of Subsurface Geology: John Wiley \& Sons, New York, NY, 273 p.

Hills, J.M., and Kottlowski, F.E. (coordinators), 1983, Southwest/Southwest Mid-Continent Region: American Association of Petroleum Geologists, Correlation Chart Series.

Holt, R.M., 1997, Conceptual Model for Transport Processes in the Culebra Dolomite Member, Rustler Formation: SAND97-0194, Sandia National Laboratories, Albuquerque, NM.

Holt, R.M., and Powers, D.W., 1988, Facies Variability and Post-depositional Alteration Within the Rustler Formation in the Vicinity of the Waste Isolation Pilot Plant, Southeastern New Mexico: WIPP DOE 88-004, U.S. Department of Energy, Carlsbad, NM, 88221

Holt, R.M., and Powers, D.W., 1990a, Geotechnical Activities in the Air Intake Shaft (AIS): DOE/WIPP90-051, U.S. Department of Energy, Carlsbad, NM.

Holt, R.M., and Powers, D.W., 1990b, Halite Sequences Within the Late Permian Salado Formation in the Vicinity of the Waste Isolation Pilot Plant, in Powers, D.W., Holt, R.M., Beauheim, R.L., and Rempe, N., eds., Geological and Hydrological Studies of Evaporites in the Northern Delaware Basin for the Waste Isolation Pilot Plant Field(WIPP): Guidebook 14, Geological Society of America (Dallas Geological Society), p. $45-78$.
Holt, R.M., and Powers, D.W., 2002, Impact of Salt Dissolution on the Transmissivity of the Culebra Dolomite Member of the Rustler Formation, Delaware Basin, Southeastern New Mexico: Abstracts with Programs, Geological Society of America, v. 34, no. 6, p. 203.

Holt, R.M., and Yarbrough, L., 2002, Analysis Report, Task 2 of AP-088, Estimating Base Transmissivity Fields. Copy on file in the Sandia National Laboratories WIPP Records Center under ERMS 523889.

Izett, G.A., and Wilcox, R.E., 1982, Map Showing Localities and Inferred Distribution of the Huckleberry Ridge, Mesa Falls and Lava Creek Ash Beds in the Western United States and Southern Canada: U.S. Geological Survey, Miscellaneous Investigations Map I-1325, Scale 1:4,000,000.

Lowenstein, T.K., 1988, Origin of Depositional Cycles in a Permian "Saline Giant": The Salado (McNutt Zone) Evaporites of New Mexico and Texas: Geological Society of America Bulletin, v. 100, p. 592-608.

Lucas, S.G., and Anderson, O.J., 1993, Stratigraphy of the Permian-Triassic Boundary in Southeastern New Mexico and West Texas, in Hawley, J.W., and others, eds., Geology of the Carlsbad Region, New Mexico and West Texas: 44th NMGS Fall Field Conference Guidebook, New Mexico Geological Society, Socorro, NM, p. 219-230.

Mercer, J.W., Cole, D.L., and Holt, R.M., 1998, Basic Data Report for Drillholes on the H-19 Hydropad (Waste Isolation Pilot Plant-WIPP): SAND98-0071, Sandia National Laboratories, Albuquerque, NM.

Powers, D.W., 2002a, Analysis Report, Task 1 of AP-088, Construction of Geologic Contour Maps. Copy on file in the Sandia National Laboratories WIPP Records Center under ERMS 522085.

Powers, D.W., 2002b, Basic Data Report for Drillhole C-2737 (Waste Isolation Pilot Plant -WIPP): DOE/WIPP 01-3210.

Powers, D.W., 2003a, Addendum 2 to Analysis Report Task 1 of AP-088, Construction of Geologic Contour Maps. Copy on file in the Sandia National Laboratories WIPP Records Center under ERMS 522085.

Powers, D.W., 2003b, Test Plan, TP 02-05 Geohydrological Conceptual Model for the Dewey Lake Formation in the Vicinity of the Waste Isolation Pilot Plant (WIPP): Sandia National Laboratories.

Powers, D.W., and Holt, R.M., 1990, Sedimentology of the Rustler Formation near the Waste Isolation Pilot Plant 
(WIPP) Site, in Powers, D.W., Holt, R.M., Beauheim, R.L., and Rempe, N., eds., 1990, Geological and Hydrological Studies of Evaporites in the Northern Delaware Basin for the Waste Isolation Pilot Plant (WIPP): Guidebook 14, Geological Society of America (Dallas Geological Society), p. 79-106.

Powers, D.W., and Holt, R.M., 1993, The Upper Cenozoic Gatuña Formation of Southeastern New Mexico, in Hawley, J.W., and others, eds., Geology of the Carlsbad Region, New Mexico and West Texas: 44th NMGS Fall Field Conference Guidebook, New Mexico Geological Society, Socorro, NM, p. 271-282.

Powers, D.W., and Holt, R.M., 1999, The Los Medaños Member of the Permian Rustler Formation: New Mexico Geology, v. 21, no. 4, p. 97-103.

Powers, D.W., and Holt, R.M., 2000, The Salt That Wasn't There: Mudflat Facies Equivalents to Halite of the Permian Rustler Formation, Southeastern New Mexico: Journal of Sedimentary Research, v. 70, no. 1, p. 29-36.

Powers, D.W., and Richardson, R.G., in review, Basic Data Report for Drillhole SNL-2 (C-2948) (Waste Isolation Pilot Plant): DOE/WIPP03-3290, U.S. Department of Energy, Carlsbad, NM.

Powers, D.W., Holt, R.M., Beauheim, R.L., and McKenna, S.A., 2003, Geological Factors Related to the Transmissivity of the Culebra Dolomite Member, Permian Rustler Formation, Delaware Basin, Southeastern New Mexico, in Johnson, K.S., and Neal, J.T., eds., Evaporite Karst and Engineering/ Environmental problems in the United States: Oklahoma Geological Survey Circular 109, p. 211-218.

Renne, P.R., Steiner, M.B., Sharp, W.D., Ludwig, K.R., and Fanning, C.M., $1996,{ }^{40} \mathrm{Ar} /{ }^{39} \mathrm{Ar}$ and U/Pb SHRIMP Dating of Latest Permian Tephras in the Midland Basin, Texas: EOS, Transactions, American Geophysical Union, v. 77, p. 794.

Renne, P.R., Sharp, W.D., Montañez, I.P., Becker, T.A., and Zierenberg, R.A., 2001, ${ }^{40} \mathrm{Ar} /{ }^{39} \mathrm{Ar}$ Dating of Later Permian Evaporites, Southeastern New Mexico, USA: Earth and Planetary Science Letters, v. 193, p. 539-547.

Rosholt, J.N., and McKinney, C.R., 1980, Uranium Series Disequilibrium Investigations Related to the WIPP Site, New Mexico, Part II: Uranium Trend Dating of Surficial Deposits and Gypsum Spring Deposit Near WIPP Site, New Mexico: U.S. Geological Survey Open-file Report 80-879, p. 7-16.

Sandia National Laboratories, 2003, Program Plan, WIPP Integrated Groundwater Hydrology Program, FY03-09,
Revisions 0. March 14, 2003. Copy on file in the Sandia National Laboratories WIPP Central Files under ERMS 526671.

Schiel, K.A., 1988, The Dewey Lake Formation: End Stage Deposit of a Peripheral Foreland Basin [unpublished M.S. Thesis]: El Paso, TX, University of Texas at El Paso, $181 \mathrm{p}$.

Schiel, K.A., 1994, A New Look at the Age, Depositional Environment and Paleogeographic Setting of the Dewey Lake Formation (Late Permian?): West Texas Geological Society Bulletin, v. 33, no. 9, p. 5-13.

Siegel, J., 2004, Transmittal of the Water Level Data for April 2004: letter to Dr. Dave Kessel, Sandia National Laboratories, dated April 27, 2004, WRES:04:539, UFC:5480.00.

U.S. Department of Energy, 1996, Title 40 CFR Part 191 Compliance Certification Application for the Waste Isolation Pilot Plant: DOE/CAO-1996-2184, October 1996, Carlsbad Field Office, Carlsbad, NM. 


\section{Appendix A Drillhole Objectives}

The basic document providing the basis for the drillhole and operations is the Program Plan WIPP Integrated Groundwater Hydrology Program, FY03-09 (Revision 0; Sandia National Laboratories, 2003). The main objectives are to resolve questions about water-level changes, provide data for modeling groundwater hydrology, and construct a network of wells to monitor groundwater through the WIPP operational period. Sections of this document relevant to this drillhole have been reproduced on the following pages, with the page number of the section preceding the extract and an ellipsis (...) following the end of the extracted section. Two figures have been included, but references and other figures are not included. The original document (Sandia National Laboratories, 2003) should be consulted for complete details and context for the program. 
p. 25

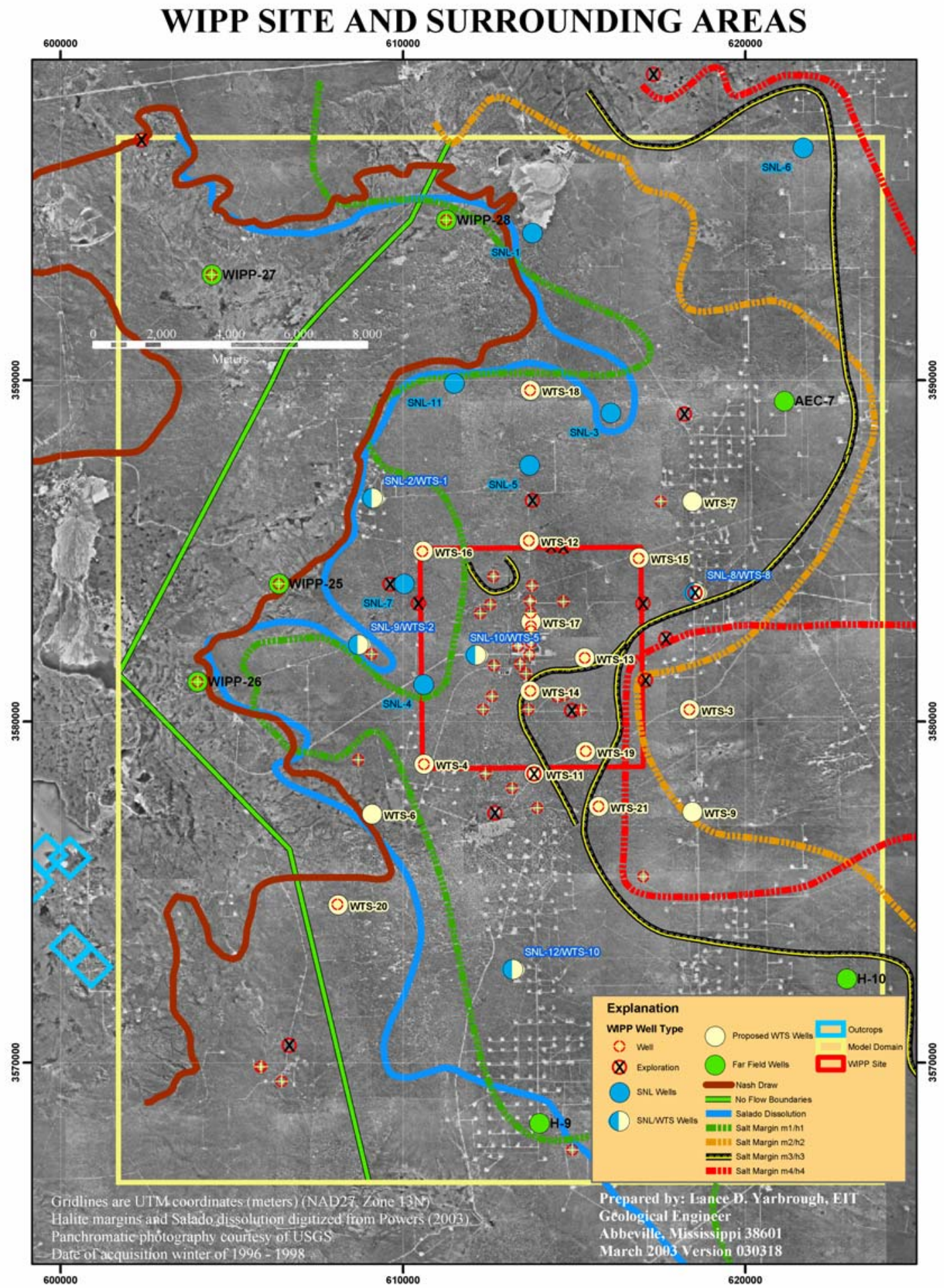

Figure 8. Air-photo map of WIPP area showing halite margins, locations of planned new wells, and Culebra model domain. 


\section{p. 39:}

\section{Description of Field Activities}

A variety of field activities are planned to address the issues discussed in Section 3 and provide data needed for the modeling activities discussed in Section 4. To the extent possible, the activities represent an integrated approach to addressing all of the issues simultaneously, rather than a piecemeal approach that addresses each issue individually. The principal components of the field activities are drilling and logging of new and replacement wells, testing in individual wells, large-scale testing involving many wells, recompletion of existing wells, and plugging and abandonment of old wells. In addition, we anticipate that various ancillary activities will be necessary to collect information to support scenario evaluation and conceptual model development. The planned schedule for the field activities, as well as for the modeling activities, is described in Section 6. The activities described below represent our best current estimate of the work that will be needed. Clearly, the activities conducted in FY04 and later years are necessarily contingent on the results of previous years' field and modeling activities. As described in Section 11, a meeting of all parties involved in the hydrology program will be held annually to evaluate progress to date and develop final plans for the coming year.

\subsection{New and Replacement Wells}

Twelve locations have been identified where data from new wells are needed. These locations are designated with "SNL-\#" labels in this document. Some of these wells are expected to provide information directly relevant to the scenarios under consideration, while others will provide information needed to support our conceptual and numerical models. In addition, a long-term Culebra monitoring network consisting of fiberglass-cased wells at potentially 21 locations has been designed to provide the data needed for compliance with the requirements of the WIPP HWFP. These wells will replace the existing network of steel-cased wells that are deteriorating and in need of plugging and abandonment. The 21 locations for the long-term monitoring network are designated with "WTS-\#" labels. Well locations have been optimized so that five wells can serve as both SNL and WTS wells, reducing the total to 28 locations. Preliminary locations for the wells are shown in Figure 8. However, the final number and locations of the WTS wells will be optimized based on the modeling described in Section 4. Seven other existing well locations outside the extent of the HWFP network have been identified that will likely require replacement wells in the future to continue to provide data needed for Culebra modeling. New Magenta wells will be installed at six of the SNL- and WTS-designated locations to provide data needed for scenario evaluation and modeling. Five Dewey Lake wells are planned for locations north of the WIPP site where Dewey Lake water is encountered while drilling the Culebra wells. The justifications for the 12 SNL locations are given below, followed by the justifications for the WTS locations and the "far-field" replacement locations. Table 1 shows the roles to be played by each of the wells. The sequencing of drilling and testing in the new wells is described and explained in Section 6. 


\subsubsection{SNL Well Justifications...}

p. 41:

Table 1. Roles Served by Planned Wells.

\begin{tabular}{|c|c|c|c|c|c|c|c|c|}
\hline Well & $\begin{array}{c}\text { Addresses } \\
\text { leakage } \\
\text { from } \\
\text { tailings } \\
\text { pile }\end{array}$ & $\begin{array}{c}\text { Addresses } \\
\text { high-T } \\
\text { conduits }\end{array}$ & $\begin{array}{c}\text { Addresses } \\
\text { leaking } \\
\text { boreholes }\end{array}$ & $\begin{array}{c}\text { Addresses } \\
\text { Salado } \\
\text { dissolution }\end{array}$ & $\begin{array}{c}\text { Provides } \\
\text { model } \\
\text { boundary } \\
\text { condition } \\
\text { information }\end{array}$ & $\begin{array}{c}\text { Provides } \\
\text { other } \\
\text { information } \\
\text { needed for } \\
\text { modeling }\end{array}$ & $\begin{array}{c}\text { Provides } \\
\text { information } \\
\text { supporting } \\
\text { conceptual } \\
\text { model }\end{array}$ & $\begin{array}{c}\text { Provides } \\
\text { information } \\
\text { on flow } \\
\text { across WIPP } \\
\text { site }\end{array}$ \\
\hline $\begin{array}{l}\text { SNL-12/ } \\
\text { WTS-10 }\end{array}$ & & $\mathrm{X}$ & $\mathrm{X}$ & & $\mathrm{X}$ & & \\
\hline
\end{tabular}

p. 46:

SNL-12/WTS-10: A Culebra well will be installed south of the WIPP site in an area where there has been extensive drilling for oil and gas (see Figures 6 and 8). This is an area where our Culebra flow models always indicate the Culebra must have high transmissivity, but no wells have been available to confirm this. It is also an area through which the water-level changes observed most markedly at H-9 propagate to the southern WIPP wells. Logs were obtained from new oil wells and potash holes in this region to help optimize the location of SNL-12. Specifically, the logs were used to identify any features that may be related to high transmissivity, especially potential dissolution of the upper Salado, to maximize the probability that SNL-12 will be located in a high-T zone. The data do not indicate local re-entrants along the Salado dissolution margin. The location was chosen to sample an area where Salado may not be dissolved, but Culebra T is likely to be high. A well at the SNL-12 location will:

1. confirm that the high transmissivity south of the site indicated by our models exists;

2. determine if dissolution of the upper Salado has occurred in this area;

3. determine if the dimensionality of flow (inferred from a pumping test) indicates that the high transmissivity is channelized (focused) or is widely distributed (diffuse);

4. provide another monitoring point to help determine the source and/or cause of the waterlevel changes regularly observed at H-9;

5. provide information on Culebra heads in an area with many nearby oil and gas wells; and

6. provide a pumping location for a large-scale (multipad) test to provide transient data for calibration of the Culebra model south of the WIPP site.

In addition, a well at the SNL-12 location will provide needed information to help define the direction and rate of Culebra groundwater flow across the WIPP site, which is required for annual HWFP reporting to NMED (hence the parallel designation WTS-10). 


\section{p. 55}

\subsection{Testing Activities}

A variety of testing and sampling activities will be performed in different wells as this program advances. Table 2 shows the types of tests currently anticipated to be performed in each new well. ...

\section{p. 56}

Table 2. Testing to Be Performed in New/Replacement Wells.

\begin{tabular}{|c|c|c|c|c|c|}
\hline Well & $\begin{array}{c}\text { 4-day } \\
\text { Pumping } \\
\text { Test }\end{array}$ & $\begin{array}{c}\text { Slug } \\
\text { Tests }\end{array}$ & $\begin{array}{c}\text { Multipad } \\
\text { Pumping } \\
\text { Test }\end{array}$ & $\begin{array}{c}\text { Scanning } \\
\text { Colloidal } \\
\text { Borescope } \\
\text { Logging }\end{array}$ & $\begin{array}{c}\text { Testing Not } \\
\text { Needed- } \\
\text { Replacement } \\
\text { Well }\end{array}$ \\
\hline SNL-12/WTS-10 & C & & C? & C? & \\
\hline
\end{tabular}

$\mathrm{C}=$ Culebra well

M=Magenta well

$\mathrm{DL}=$ Dewey Lake well

p. 57

\subsubsection{Multipad Pumping Tests}

Large-scale (multipad) pumping tests of the Culebra are planned for three locations to provide transient response data needed for flow-model calibration. Multipad pumping tests typically involve pumping for a month or longer at one location while monitoring responses at surrounding observation wells up to several miles away. Such tests have been performed in the past within the WIPP site boundaries at the H-3, H-11, H-19, and WIPP-13 locations, greatly facilitating model calibration in the affected areas where observation wells were present. The new wells to be installed provide the opportunity to extend the increased model-calibration capability provided by multipad tests to the regions surrounding the WIPP site, which is needed to improve our understanding of how hydraulic stresses originating off-site propagate to the wells on the WIPP site. In particular, one of the primary objectives of the multipad tests will be to determine the presence or absence of high-transmissivity connections between known areas of high T, such as between H-6 and P-14, and between H-11 and H-9. These types of features are important because, if present, they provide pathways for water from Nash Draw to flow under the Livingston Ridge surface or, if absent, they prevent that flow so that the only effect of increased heads in Nash Draw is to decrease the east-to-west gradient in the Culebra, causing heads to rise. Multipad tests will be performed north, south, and west of the WIPP site. (Transmissivity is too low east of the site to sustain the necessary pumping for a multipad test, and our conceptual model assumes the Culebra does not show the heterogeneity in this region that multipad tests are designed to address. The individual well tests at the new wells east of the site should be sufficient to confirm this assumption.) 
Well SNL-9/WTS-2 will be the pumping well for the western multipad test, with observation wells as shown in Figure 18. Provided that it is able to produce at least approximately $5 \mathrm{gpm}$, SNL-5 will be the pumping well for the northern multipad test, with observation wells as shown in Figure 19. If SNL-5 does not have the needed pumping capacity, SNL-11, SNL-3, and WTS-12 (in that order) will be considered as potential fallback pumping wells for the test. The pumping well for the southern multipad test will prospectively be SNL-12/WTS-10, with observation wells as shown in Figure 20. Should SNL-12/WTS-10 not have the required pumping capacity, WTS-11 and WTS-6 (in that order) will be considered as fallback pumping locations. 


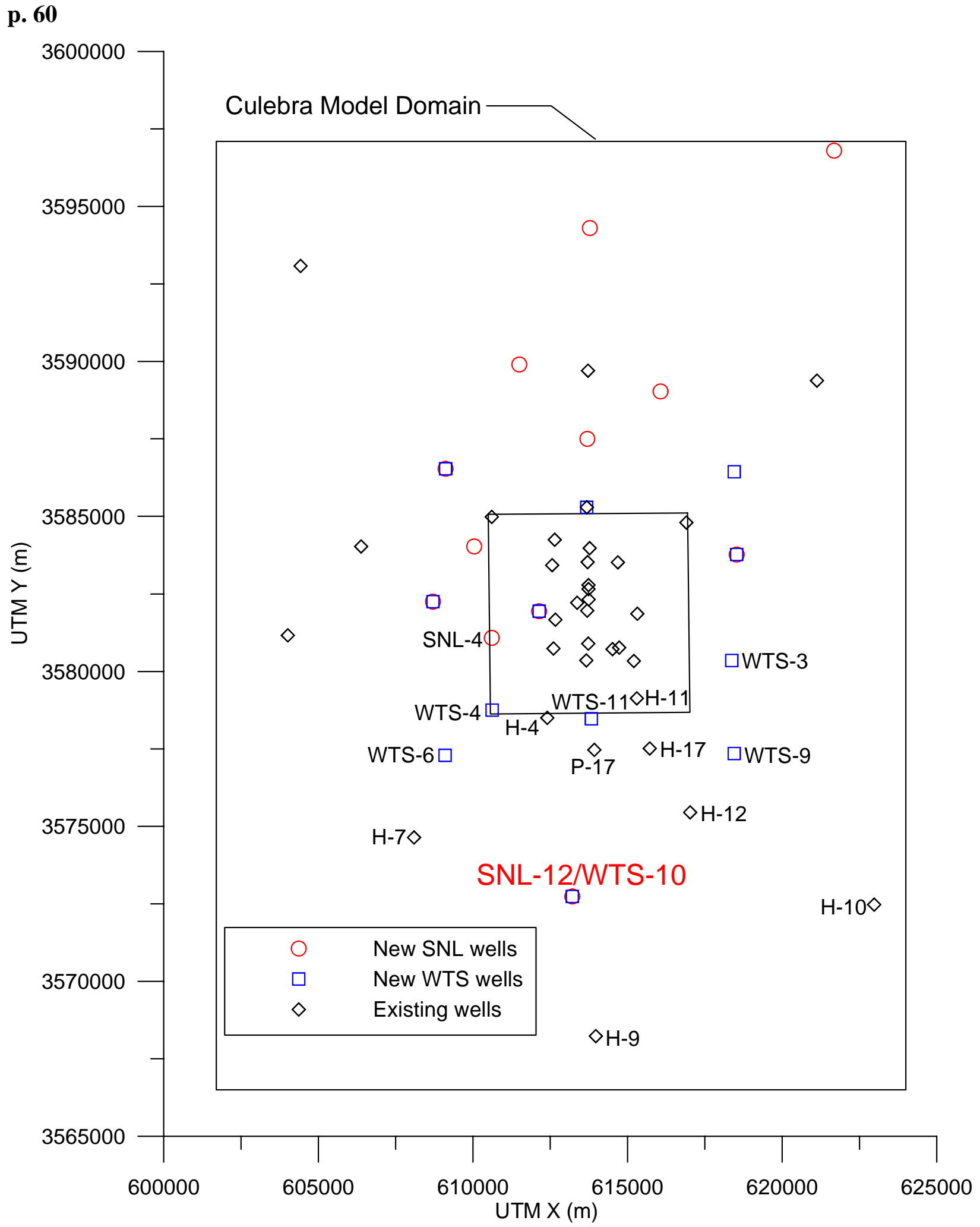

Figure 20. Pumping well and principal observation wells for southern multipad pumping test. 
p. 67

\subsection{Decision Points ...}

If high Culebra $\mathrm{T}$ is not found at the SNL-12 location, we would have to re-evaluate the lines of geologic evidence that led us to site the well where we did, evaluate whether the information gained from drilling the hole allowed us to make a better prediction of where high $\mathrm{T}$ could be found, and decide if drilling another hole to try to find it was worthwhile.

p. 70

Table 4. Expectations and Contingent Actions for New Wells.

\begin{tabular}{|r|l|l|}
\hline Well & \multicolumn{1}{|c|}{ Expectations } & $\begin{array}{c}\text { Possible Actions if Expectations } \\
\text { Not Met }\end{array}$ \\
\hline $\begin{array}{l}\text { SNL-12/ } \\
\text { WTS-10 }\end{array}$ & $\bullet \begin{array}{l}\text { moderate to high Culebra T } \\
\text { possible dissolution of upper Salado }\end{array}$ & $\begin{array}{l}\text { reconsider geologic data and } \\
\text { determine location for possible } \\
\text { additional well }\end{array}$ \\
\hline
\end{tabular}

p. 72

Table 5. Anticipated Total Depths of Proposed Wells.

\begin{tabular}{|c|c|c|c|}
\hline Location & $\begin{array}{c}\text { Culebra } \\
\text { Well Depth } \\
\text { (ft) }\end{array}$ & $\begin{array}{c}\text { Magenta } \\
\text { Well Depth } \\
\text { (ft) }\end{array}$ & $\begin{array}{c}\text { Dewey } \\
\text { Lake Well } \\
\text { Depth (ft) }\end{array}$ \\
\hline SNL-12/WTS-10 & $920 *$ & & \\
\hline
\end{tabular}

*depth to MB103

$\cdots$

p. 73

Dissolution of the upper Salado Formation will be studied in up to eight drilling locations: SNL-2, 3, 4, 7, 9, and 12 and WTS-4 and 6. At these selected locations, the boreholes that will become the Culebra wells will be cored from the lower part of the upper Tamarisk anhydrite to the halite beds of the upper Salado (approximately $175 \mathrm{ft}$ ), and then will be rotary drilled through Marker Bed (MB) 103. If MB100, 101, or 102 are well defined, the on-site geologist together with the Lead Hydrologist and Field Operations Lead may terminate drilling at any one of these marker beds. If MB103 is disturbed by deeper dissolution, the borehole may need to be deepened by an estimated additional $100 \mathrm{ft}$ by rotary drilling through MB109 or other suitable stratigraphic marker bed as determined by the on-site geologist in consultation with the Lead 
Hydrologist and Field Operations Lead. This decision is most likely for four holes (SNL-2, SNL-3, SNL-11, and SNL-12) where the uppermost Salado may have been dissolved to greater depths, obscuring the upper Salado stratigraphic record. After all desired core and geophysical logs have been collected from the upper Salado, the holes will be plugged with cement back to a depth approximately $20 \mathrm{ft}$ below the base of the Culebra before the upper part of the hole is reamed to its final diameter.

\section{p. 74}

\subsection{Logging}

Open-hole geophysical logging will be performed after each Culebra hole is drilled to total depth and reamed, but before the casing and well screen are installed. Wells drilled into the upper Salado will be logged prior to reaming, and caliper logging will be repeated after reaming. The suite of logs to be run in all wells includes: natural gamma, resistivity (induction if the well is not fluid-filled), neutron, density, and caliper. These logs will be used to confirm stratigraphic contact depths determined from core, and will aid in selecting final casing and screening depths. In addition, a high-resolution microresistivity log (e.g., FMI, FMS, EMI) will be run in the SNL-2 Culebra well to determine its effectiveness at identifying fractures and their orientations. If successful, a microresistivity log may be run in other holes. In the Magenta and Dewey Lake wells, only natural gamma and caliper logs are planned, although resistivity (or induction) and neutron $\log$ s could be required in Dewey Lake wells to resolve uncertainty about the zone of saturation. After well completion, an acoustic cement-bond log may be run to provide a baseline of cement conditions behind the well casing. The logger must provide all logs in both paper and digital form. 
Appendix A Drillhole Objectives

This page is intentionally left blank. 


\section{Appendix B Abridged Borehole History}

The abridged borehole history has been prepared by compiling information from driller's reports by West Texas Water Well Services (WTWWS) personnel, on-site reporting by Washington Regulatory and Environmental Services (WRES) personnel, and geologic logs by Dennis W. Powers. The main information is from WTWWS reports, which are reported as Central Daylight time. For consistency, all information in the abridged borehole history has been converted to Central Daylight time, regardless of source. Original files are maintained by WRES in the Environmental Monitoring and Hydrology Section. 
Note: The abridged drillhole history provided here has been compiled mainly from the daily records produced by personnel of West Texas Water Well Service (WTWWS) and provided to Ron Richardson (Washington Regulatory and Environmental Services). The information has been reformatted and has been modestly edited. Additions to the record from notes by Dennis Powers or other personnel are in italics. All times reported in the abridged drillhole history are in CDT (Central Daylight Time) as recorded by WTWWS because they operate from Odessa, TX. Any additional notes included here (in italics) with times recorded in MDT (Mountain Daylight Time) at the site have been converted to CDT. Geologic logs (main body of text) have times as MDT, and times in the geologic logs commonly vary slightly from driller's log after allowing for the hour time difference.

6-23-03 Arrived at SNL-9 site at 11:20 CDT (see note above). Held safety meeting. Began shutting rig down and moving equipment from SNL-9 to SNL-12 at 11:35. Began shutting down both sites at 17:10 (due to bad lightning storm). Left SNL-9 site at 18:00.

6-24-03 Arrived at site at 07:00. Held safety meeting. Finished moving equipment, cleaning up, and pouring slab on SNL-9 by 11:30. Hauled one load of fresh water and brought Ron's generator from WIPP site by 12:30. Stopped for lunch. Brought mobile home from WIPP site to SNL-12 by 14:00. Rigged up on SNL-12. Left site at 17:30.

6-25-03 Arrived at site at 07:00. Held safety meeting. Lined pit at 07:15. Drilled 30' of 7.875" hole from 08:05 to 08:22. Collected cutting samples $C-1$ through $C-7$. Blowing out cavity at bottom of hole. Set up to ream hole with air and mist. Began reaming out 18'" hole at 09:39. Reamed to 30 ' at 11:00. Set 30' of 13.385" casing with 2' hole plug from 11:00 to 11:30. Rigged up to mix cement at 11:30. Pumped 28 bags of cement in 300 gallons of water by 12:30. Shut down rig and generator for night and left site at 12:45.

6-26-03 Arrived at site 07:00 and held safety meeting. From 07:15-07:25, tagged cement at 7' and mixed 6 sacks of cement. Rigged diverter up from 07:25-09:06. Drilled 7.875" hole from 30' to 175 ' with compressed air. Collected cutting samples $C-8$ through $C$-22. Tripped out from 12:55 to 13:10 for hold point to determine if well makes water. Water level was $164.3 \mathrm{ft}$ below top of casing at 14:00. Pulled a water sample at 14:10 for Sandia to obtain major cations and anions. Took another water sample at 15:00 for Sandia analysis. Measured depth at 155' from top of casing at 15:16. Decided to break for holiday and allow well to recover for further sampling. Crew removed hydraulic pump to repair during drilling break.

7-07-03 Arrived on site at 10:30. (Held safety meeting at 08:20 in Odessa.) Began setting up rig and trailer for continued drilling. Completed installing rig pumps by 13:15. Static water level at $141.55^{\prime}$ at 13:18. Collected two bailer samples from Dewey Lake water bearing zone from 13:18 to 13:30. Sample measurements: density at $0.999 \mathrm{~g} / \mathrm{cc}$; temperature at approximately $22.5^{\circ} \mathrm{C}$. Tripped into hole at 13:30 to 13:40. Began drilling using foam mist at 13:45. Drilled 7.875" hole from 175' to 371'. Still in Dewey Lake. Collected cutting samples C-23 through C-42. Still in Dewey Lake. Pulled out of hole for the night at 17:42. Planned on coring in the morning.

7-08-03 Arrived on site at 06:50. Held safety meeting. Serviced rig from 07:10. Measured water level at 155.0' at 07:35. Tripped into hole at 07:45. Began drilling 7.875" hole at 371 ' and drilled to 
425'. Collected cutting samples $C$-43 through C-52. Started tripping out of hole at 09:40, installed core barrel, and tripped back into hole with core barrel by 11:35. Began core run \#1 at 11:35 using compressed air and foam. Cored approximately 29 ' from 425 ' to 454 ' by $12: 16$. Cleaned hole with circulating foam. Tripped out of hole. Retrieved core at 12:40 and placed core in tray. Stopped for lunch 13:15 to 13:45. Cleaned and measured core. Retained 29.3'. Tripped back into hole at 13:45. Began core run \#2 at 14:05. Cored 16.5' from 454' to 470.5' by 14:20. Cleaned hole. Tripped out. Retrieved and laid out core. Retained 16.5'. Boxed cores. Secured tools and equipment. Left site at 16:00.

7-09-03 Arrived on site at 06:50. Held safety meeting. Measured water level at 142.3' at 07:30. Tripped into and cleaned out hole. Began reaming through cored interval at 08:30. Continued drilling from 470.5 ' to 520'. Collected cutting samples $C-53$ through $C 055$. Stopped to repair rig (bearing out) at 09:49. Resumed drilling at 11:38. Reached coring point and tripped out of hole to attach core barrel at 12:30. Stopped for lunch. Tripped back down hole at 13:00 and got a load of fresh water. Began core run \#3 at 14:00 and ended at 14:25. Cored 28' from 520' to 548'. Circulated mist in hole. Retrieved core at 15:10 and laid down core. Tripped back down into hole and began core run \#4 at 15:54. Cored 29' from 548' to 577'. Last anhydrite and into Culebra. Retrieved core to Culebra at 16:15. Retained 29'. Boxed cores at 17:00. Advised Beauheim that drilling with brine would begin tomorrow. Secured site. Left site at 18:00.

7-10-03 Arrived on site at 06:50. Held safety meeting. Rigged up portable mud system. Prepared for drilling. Took generator off-site to be cleaned. Steam radiator on auxillary generator. Two loads of brine delivered by I/W. Measured static water level at 143.5' at 11:00. Tripped into hole with core barrel at 11:50. Cleaned hole near Culebra base at 577'. Began core run \#5, drilling with brine with Flowzan. Cored approximately $13^{\prime}$ from 577 ' to 590'. Halted coring for lunch at 12:25. Resumed core run \#5 at 12:40. Cored additional 10' to 600' when core barrel jammed at 14:11. Circulated on bottom, and tripped out by 14:53. Retrieved core and laid down in tray. Measured 23' of core recovered from middle to lower Culebra. Tripped back down hole at 15:37. Began core run \#6. Blew hydraulic hose on pump for mist at 16:50. Pulled out of hole. Needed to replace hose off-site (unable to isolate leak). Returned to site with repaired/replaced parts at 18:00. Tripped into hole and circulated to prepare for continuation of coring. Began core run \#6 at 18:10. Cored 10' from 600' to 610'. Ceased coring at 18:48 and circulated until 18:55. Tripped out of hole. Left core in barrel and planned to lay out core the next morning. Left site at 19:28.

7-11-03 Arrived on site at 06:50. Held safety meeting. Measured static water level (from drilling brine) at 28'. Laid down core from previous night's runs at 07:00. Measured 10' of core recovered (as planned) at 07:30. Tripped down hole and began core run \#7 at 08:22. Boxed core from run \#6 at 08:30. Cored approximately 28 ' from 610' to 638' by 10:30. Tripped out of hole, laid down core, and prepared to trip into hole by 11:10. Attempted to remove core from core barrel. Only small portion of crumbled clay removed. Lost an estimated 10' of core. Recovered 18' of 28' run. Tripped back down hole by 12:15 and stopped for lunch. Began core run \#8 at 12:30. Cored 28' from 638' to 666' by 14:50. Circulated hole and tripped out by 15:45. Laid core in trough and measured 20' of recovered core. WTWWS serviced rig and left site at 16:30. Described, boxed, and secured core by 17:30. 
7-12-03 Arrived on site at 06:50. Held safety meeting. Set up rig and coring equipment. Tripped into hole and began core run \#9 at 08:05. Cored 24.5' from 666' to 690.5' before barrel jammed; circulated in hole. Tripped out of hole at 10:26. Extracted core from barrel. Recovered 17.8' of 24.5'. Tripped into hole and began core run \#10 at 11:25. Cored 29.5' from 690.5' to 720' by 13:05. Circulated hole. Stopped for lunch. Pulled core barrel and extracted core at 14:37. Coring complete. Disassembled core barrel and loaded for J.W. Woods (DOWDCO) and released him. Measured 30' of recovered core. Prepared core for boxing and description. Completed boxing core at 16:15. Left site at 16:20.

7-13-03 Arrived on site at 06:50. Held safety meeting. Started generator. Tripped down hole. Began reaming 63/4" to 7.875" hole from 520' to 720'for sampling Salado MB 103 at 07:45. Noted 8' of washout from 528' to 536' at 08:00. Noted 10' of washout from 590' to 600'. Noted 5' of washout from 610' to 615'. Hole is holding fluid; no loss. Reamed to 720' by 12:20. Began drilling at 720' in Salado at 12:20. Collected cutting samples $C-56$ through C-67 (905', TD). Reached total depth of 905' at 19:00. Circulated hole until 19:15. Tripped out of hole and secured site. Left site for Carlsbad at 20:20.

7-14-03 Arrived on site at 08:15. Held safety meeting. Prepared for electric logs. Began running $\operatorname{logs}$ at 08:40. Completed logs and stopped for lunch at 12:30. Tripped tremmie pipe down hole at 13:00, off bottom by 7'. Started mixing first tub of cement at 13:44 using 30 sacks. Pumped first tub from 14:17 to 14:25. Pulled 1 full joint of tremmie pipe, 1 pug joint; $45^{\prime}$ total. Began mixing second tub using 27 sacks at 14:25. Pumped second tub from 15:19 to 15:23. Pulled 4 joints; tremmie approximately 120'. Started mixing approximately $1 / 4$ tub using 13 sacks at 15:23. Pumped third tub from 16:00 to 16:05. Tripped out and shut down rig for evening at 16:27.

7-15-03 Arrived on site at 08:15. Held safety meeting. Performed rig maintenance from 08:30 to 10:00. Trip into hole and tag cement at 603 '; 2 ' of fill on top of cement. Tripped out from 10:35 to 11:10. Rigged up 121/4" bit and hauled 1 load of water at 11:10. Left site at 12:15.

7-16-03 Arrived on site at 07:00. Held safety meeting. Measured static water at 76.2'. Prepared to ream hole from 7.875" to $121 / 4$ ". Began reaming at 30' at 08:00. Reamed to 62' by 08:30. Reamed to $91^{\prime}$ by 09:30. Reamed to $152^{\prime}$ by 13:00. Reamed to 183' by 15:00. Drilling rate approximately $15^{\prime}$ per hour. Reamed to $214^{\prime}$ by 16:43. Reamed to 230' by 17:50. Circulated hole. Tripped out from 18:00 to 18:10. Secured site for evening and left at 18:25.

7-17-03 Arrived on site at 07:00. Held safety meeting. Measured static water at 29.6'. Tripped into hole at 07:10. Began reaming to $12{ }^{\prime} / 4^{\prime \prime}$ at 230' at 07:20. Reamed to 278' by 09:45. Reamed to 341 ' by 14:45. Reamed to 373 ' by $16: 15$. Circulated hole. Tripped out at 16:30. Secured site for evening.

7-21-03 Arrived on site at 08:30. Held safety meeting. Measured static water at 86.4'. Rigged up auxillary mud pump at 08:45. Reamed back to bottom from 09:15 to 10:30. Began drilling 121/4" from 373' at 10:30. Progress slow. Drilled first joint, taking 3 hours to drill 30'. Casing inspected by state engineer at 12:30. Pulled out at 436' to add another joint of pipe in order to ream deeper. 
Previous joint took 21/2 hours to drill. Drilled to 463' by 17:45. Circulated hole. Tripped out at 18:00. Secured site for evening.

7-22-03 Arrived on site at 07:00. Held safety meeting. Tightened rotary joints on rotary table. Measured static water at 72'. Tripped into hole at 07:45. Hole closed in at 200'. Reamed through and continued tripping into hole. Began drilling 12 1/4" at 463' at 08:35. Drilled to 531' by 18:40. Circulated hole. Started tripping out of hole at 18:50. Hung in hole temporarily at 410'. Completed tripping out at 19:40.

7-23-03 Arrived on site at 07:00. Held safety meeting. Serviced rig and changed bits. Began tripping in at 08:00. Reamed back to bottom. Circulated hole at 09:30. Began drilling at 531' at 09:50. Drilled to 571' by 16:30. Circulated hole. Tripped out at 16:45. Changed bit and shut down rig at 17:40. Left site at 18:00.

7-24-03 Arrived on site at 07:00. Held safety meeting. Serviced rig and changed bits. Measured static water level at 74.3'. Tripped drill pipe into hole at 08:00. Began reaming hole at 571' at 09:00. Reamed to 603' by 12:10. Circulated hole. Tripped out of hole at 12:45. Ran caliper well log at 13:20. Stopped for lunch at 14:15. Left site at 14:40 for WTS\#4.

7-25-03 Arrived on site at 07:00. Held safety meeting. Measured static water level at 74'. Tripped drill pipe down hole at 07:15. Reamed through tight spots and circulated hole. Ran tremmie pipe in hole at 10:24. Began to run 5" fiberglass reinforced plastic casing at 11:10. Encountered fill in hole at 13:00. Attempted to wash out. Calculations indicated the fill to be approximately 30' from bottom of hole. Unable to clean out hole by pumping through tremmie. R. Richardson and WTWWS decided to pull casing and reenter hole next week. Began to pull 5" casing out of hole at 14:20. Pulled tremmie pipe out of hole at 15:56. Two loads of brine delivered by I/W. Secured site and left for weekend.

7-28-03 Arrived on site at 11:00. Performed rig maintenance. Left site at 16:00.

7-29-03 Arrived on site at 06:00. Held safety meeting. Changed generator for portable mud system at 06:15. Tripped into hole at 06:45. Necessary to ream almost entirely to bottom. Circulated hole until 10:47, and tripped drill pipe out of hole. Ran tremmie pipe at 11:18. Began to run 5 " fiberglass reinforced plastic casing at 12:15 (0' - 546' blank; 546' top of screen; 584' bottom of screen; 595' to bottom is blank). Stopped for lunch at 13:45. Prepared to gravel pack at 14:10. Used 34 sacks (3100 pounds of 8/16) to bring gravel pack up to 540'. Pumped 4 sacks of Baroid Holeplug at 15:20 to bring level to 535'. Prepared to pump cement at 15:30. State Engineer representative (Mike Stapleton) arrived on site at 15:50 to witness cementing. LaFarge on location with 15 yards. Pumped cement from 17:00 to 17:55. Laid down tremmie pipe from 17:55 to 18:20. Cleaned up cement pump and shut down for evening. Left site at 18:35.

7-30-03 Arrived on site at 09:15. Held safety meeting. Serviced rig at 09:30. Tripped 2" pipe into hole at 10:00. Flushed casing out with clean water from 10:30 to 12:30. Tripped 2" out at 12:30. Stopped for lunch at 13:00. Rig down from 14:00 to 18:00. 
8-04-03 Arrived on site at 11:00. Started initial pumping at 11:05; water is muddy. First flow rate of 691 BPD (barrels per day) at 11:15. Pumped steadily for 15 minutes until water clear at 11:30. Pumped total of 7 barrels; rate of $16 \mathrm{gpm}$. Started backwash/surge at 11:40; total of 11 barrels pumped. Resumed pumping at 12:00; rate of 26 gpm (steady). Measured drop in flow to $23.3 \mathrm{gpm}$ at 12:15; total of 20 barrels pumped. Regained steady clear flow of 23 gpm at 12:25; total of 25 barrels pumped. Started backwash/surge again at 12:32. Started pumping, full open, at 12:47; rate of $26.5 \mathrm{gpm}$, total of 32 barrels pumped. Flow very steady and clear at 13:15; total of 44 barrels pumped. Measured density of $1.020 \mathrm{~g} / \mathrm{cc}$ at 14:20. Total production of 80 barrels at 14:25. Stopped pumping at 14:30; water totally clear and clean.

4-05-04 Arrived at portacamp at 07:30. Crew arrivee at portacamp at 09:00. Arrived at SNl-12 at 09:30. Started down hole. Screen interval from 546-584 ft, added joints to $588 \mathrm{ft}$. Jet tool set at 10:15; ready for development. One hundred fifty barrels of water from Jal Municipal water supply was available. Started jettying at 10:30; water started pretty clean and became real dirty. Water was very dark brown and muddy by 10:40, with chunks of mud floating up. Jetted entire screen interval plus about $1 \mathrm{ft}$ above and below screen. Completed first full past by 10:55; water still dirty. Completed second full pass by 11:25; water becoming cleaner. Completed last half pass by 11:35. Flushed 150 barrels through well and pumped into frac tank. Water was still cloudy and light gray color. Removed pipe and jet tool from well by 12:15 and began to set 3 horsepower pump. Pump was set at 12:55; set up to start pumping. Began pumping at 13:10 at $14 \mathrm{gpm}$. Flow rate $14 \mathrm{gpm}$ at 13:20; water slightly cloudy. Flow rate $14 \mathrm{gpm}$ at 13:30. Flow rate $13.8 \mathrm{gpm}$ at 13:45. Flow rate at $14.2 \mathrm{gpm}$ at 14:00. Flow rate at $15.0 \mathrm{gpm}$ at 14:15; water milky, cloudy. Flow rate at 15.0 gpm at 14:30; water slightly cloudy. Flow rate at $14.3 \mathrm{gpm}$ at 15:00. Fluid density $1.004 \mathrm{~g} / \mathrm{cc}$, and water was very clear. Flow rate at 15:30 was $14.7 \mathrm{gpm}$. Water very clear, and fluid density at $1.004 \mathrm{~g} / \mathrm{cc}$. Flow rate was $14.7 \mathrm{gpm}$ at 16:00. Density was $1.004 \mathrm{~g} / \mathrm{cc}$, and water was very clear. Turned pump off at 14:05. Water showed no sediment. Pumped total of 2526 gallons. Removed pipe and pump from hole by 17:00. Returned pipe trailer to portacamp by 17:30. 


\section{Appendix C Geologic Logs}

Note: The original field descriptions and graphic logs were prepared at somewhat variable scales, and the graphic logs for publication were generally produced at 10 or 20 vertical feet per inch. indicated in the header for the log. For publication purposes, the figures were reduced to $95 \%$ of the original size, and the scale indicated will be incorrect. The vertical footage log is reduced proportionally and will still be correct. 


\section{Explanation of Symbols Used in Lithologic Logs (Appendix C)}

\section{Lithology}

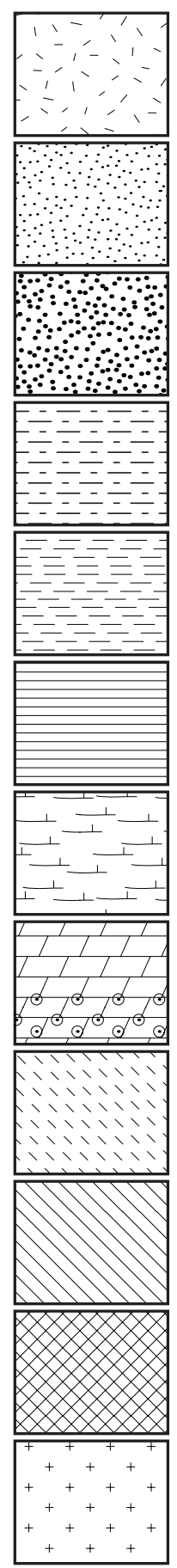

Construction fill

Fine sand or sandstone

Medium or coarse sand or sandstone

Siltstone

Claystone

Organic-rich, claystone

Carbonate (pedogenic calcrete)

Dolomite (with öolites)

Gypsum

Anhydrite

Polyhalite

Halite

\section{Features}

$\gg$ Cross-cutting strata

Ripples

Y Bioturbation

$\odot^{\odot} \odot{ }^{\odot} \odot \odot^{\odot} \odot \quad$ Olites

$\approx \sim$ Wavy bedding

ลัธณัณ Stromatolites, algal bedding

$Y \quad$ Vertical gypsum crystals

$\mathbb{Q} \quad$ Gypsum nodules

$\bigcirc \quad$ Clasts, may show lithology as fill pattern

7 Brecciated, fractures

f Fractures, filled or unfilled

Erosional boundary Sharp lithologic contact

- - - - Gradational lithologic

............. contacts

sl $\quad$ Slickensides

ns No cuttings sample

Symbols may be combined; not all symbols may be used 


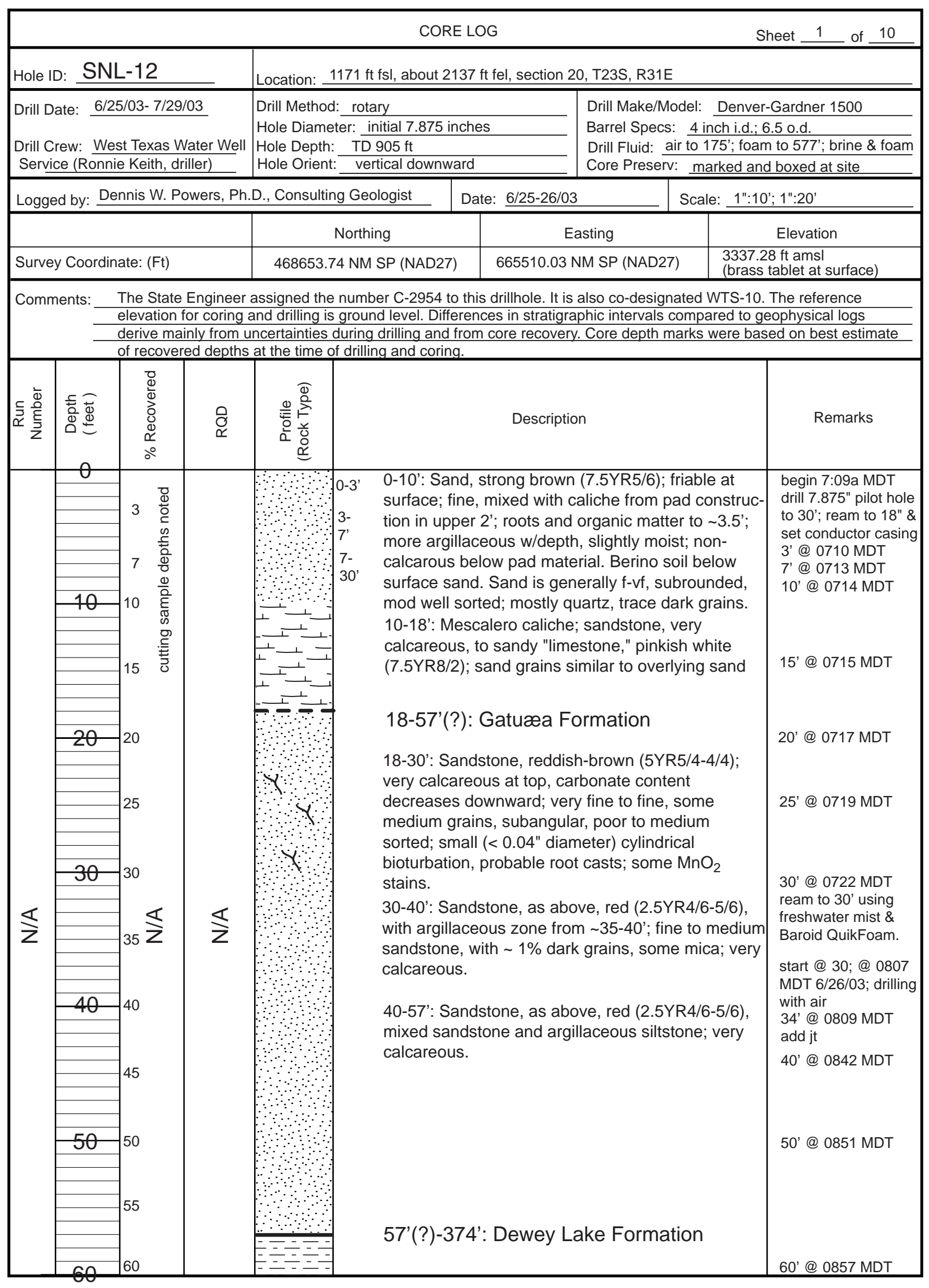




\section{Appendix C Geological Logs}

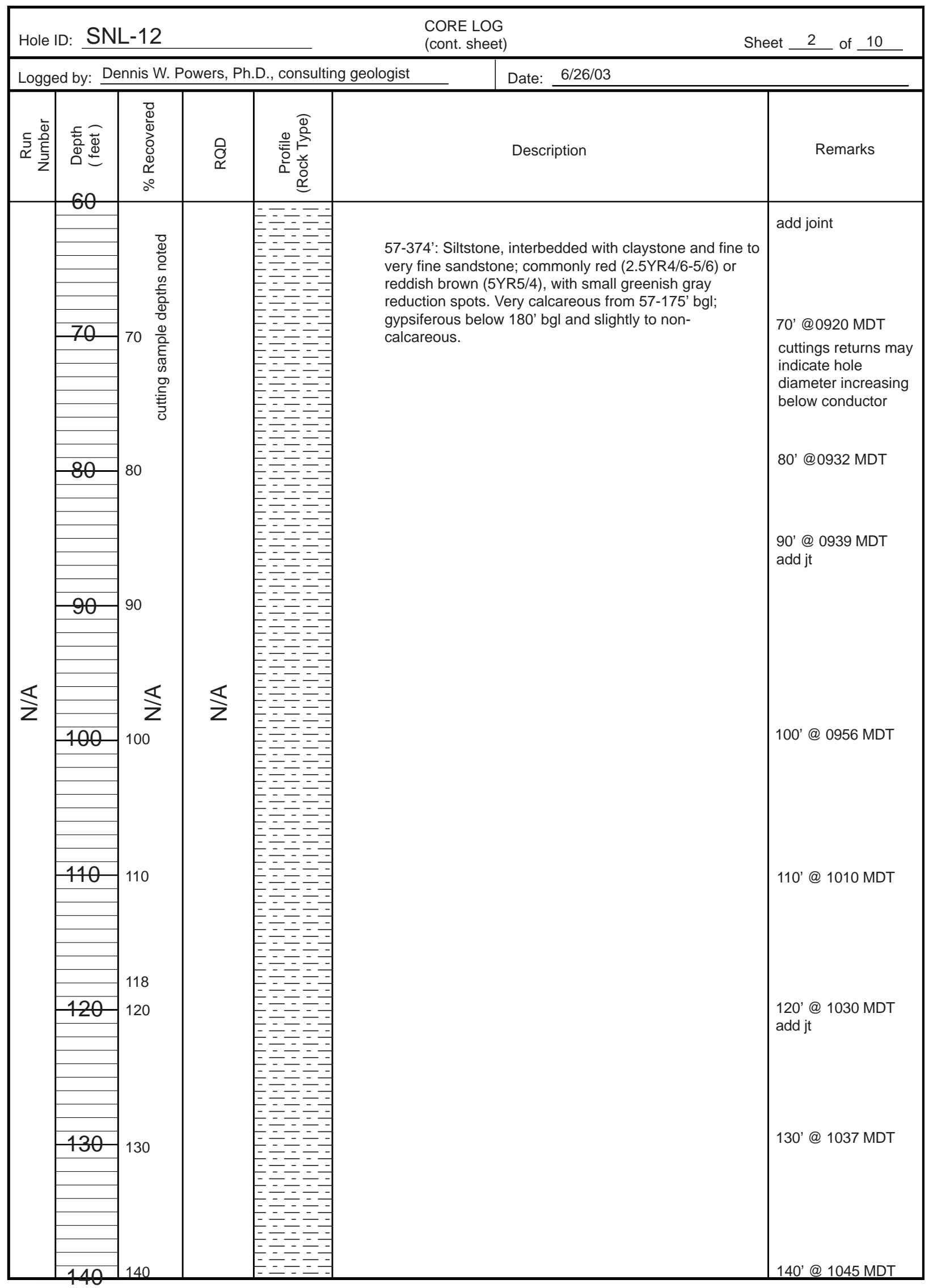




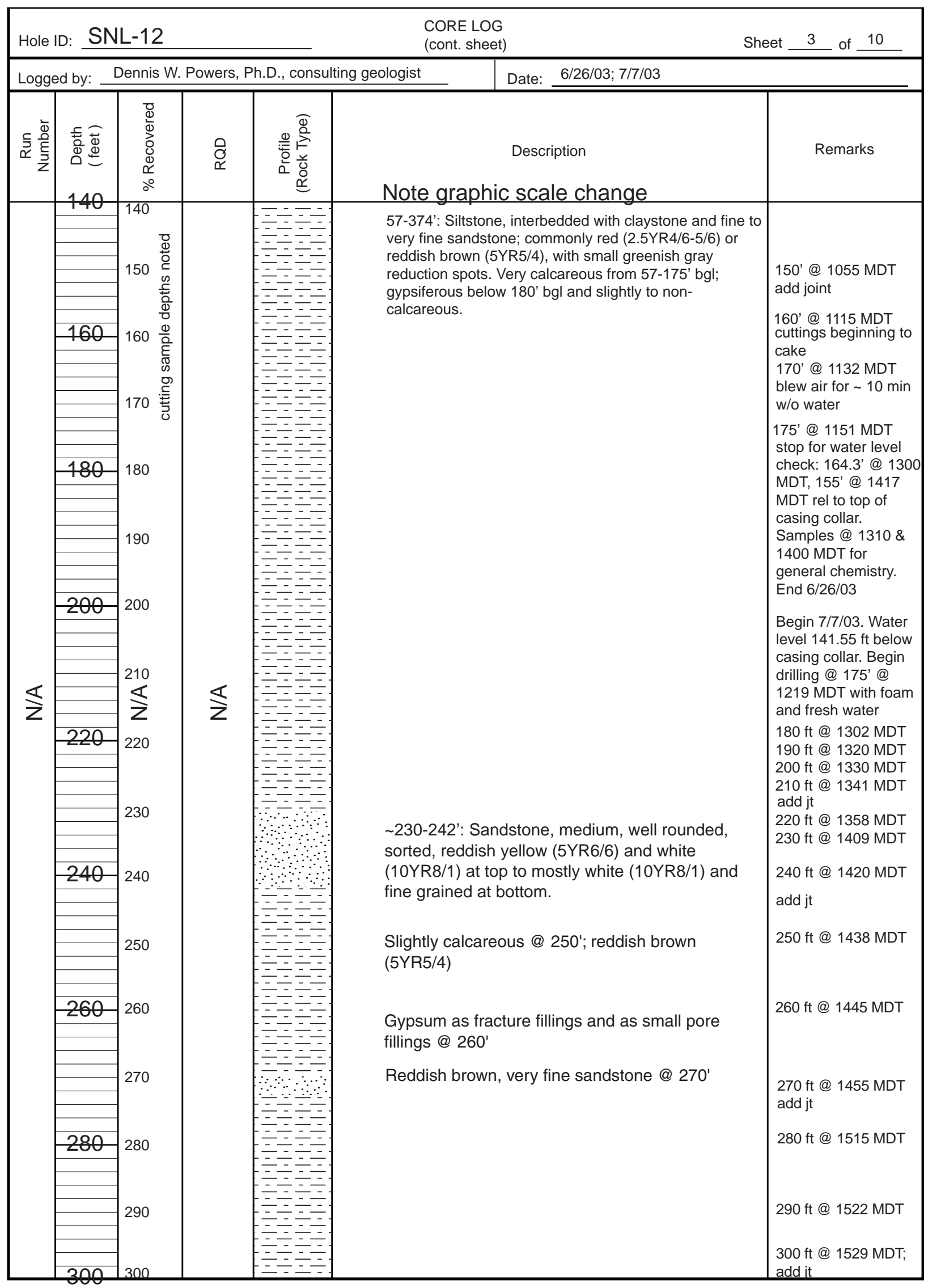




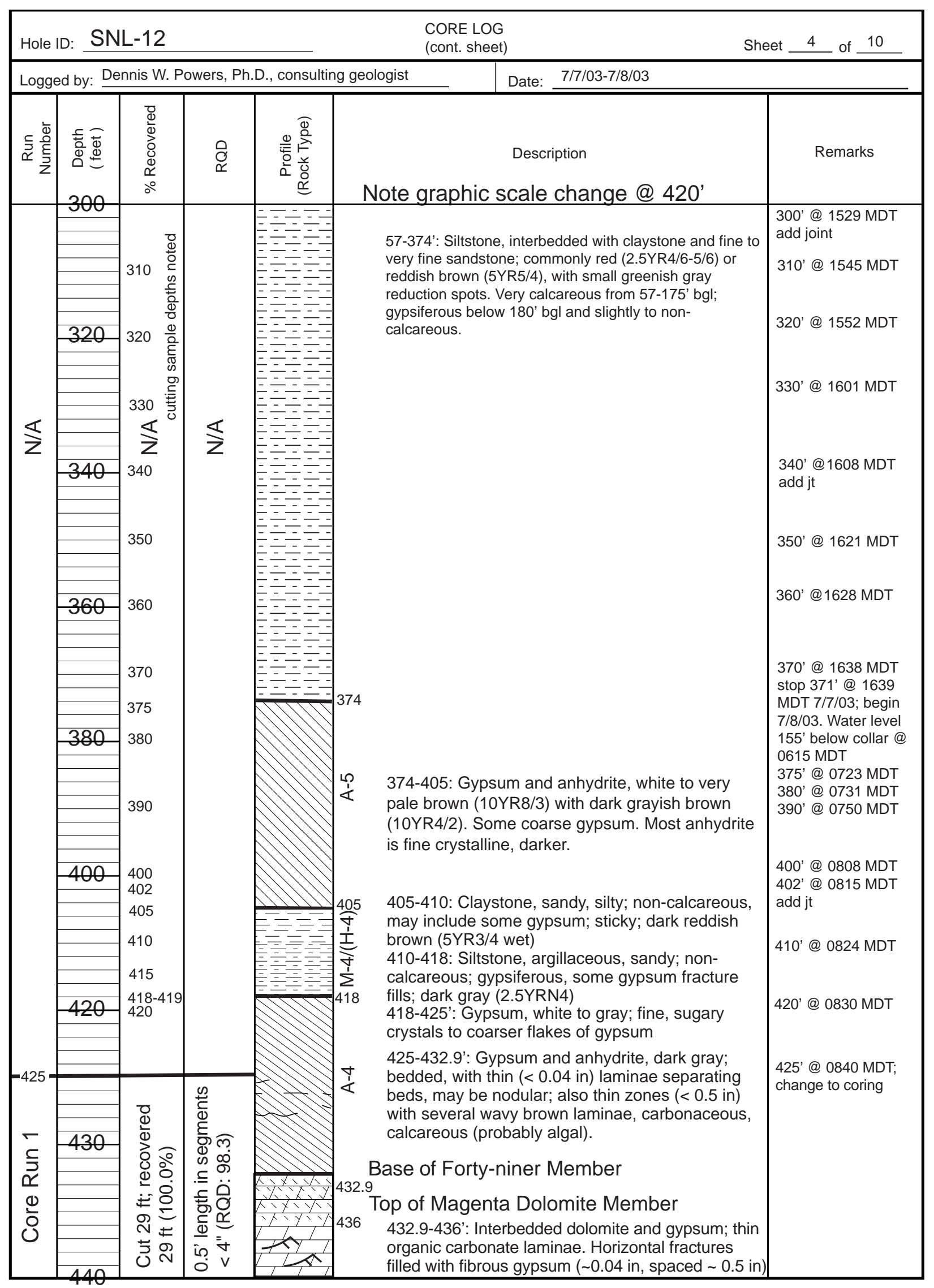




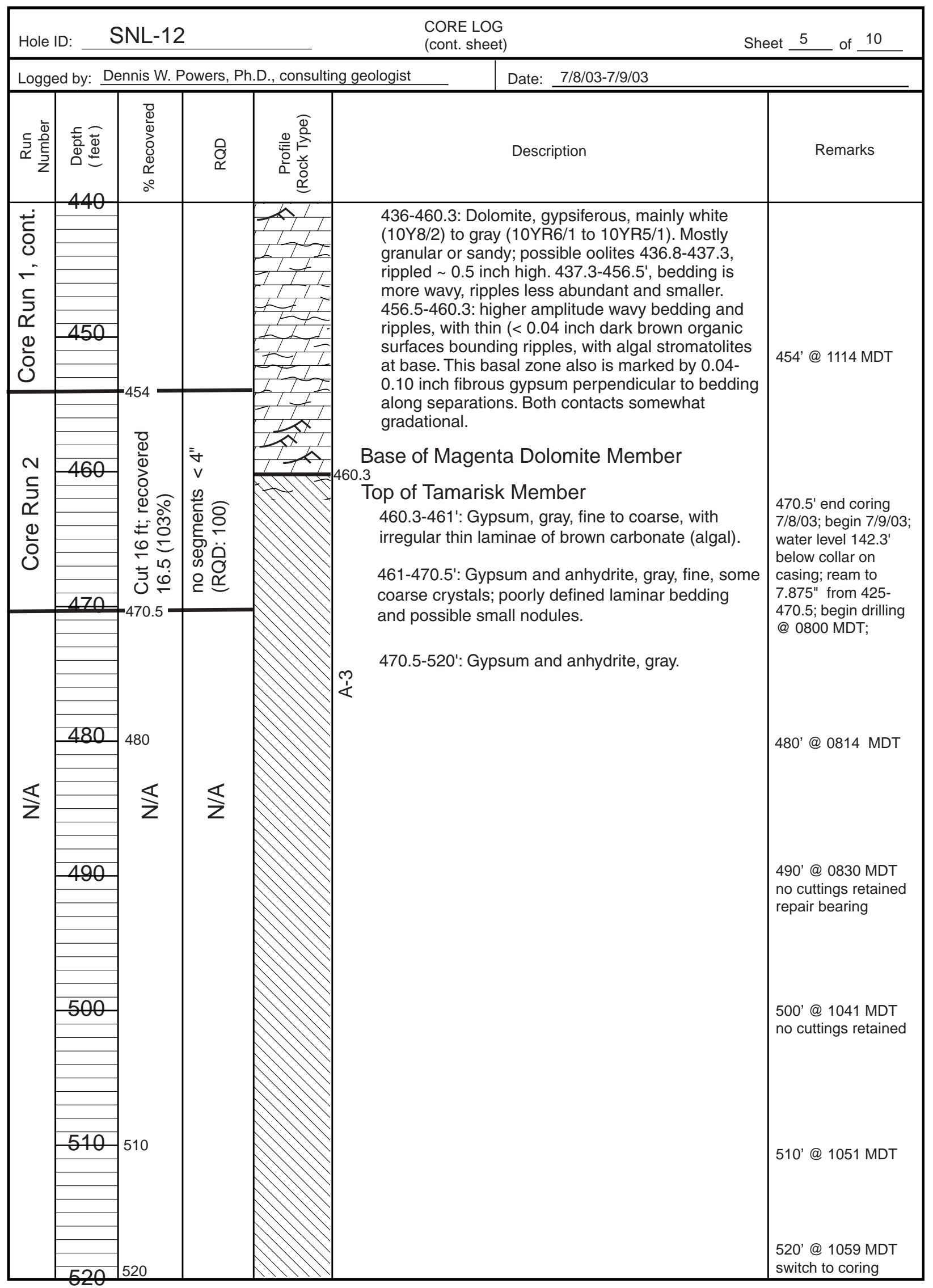




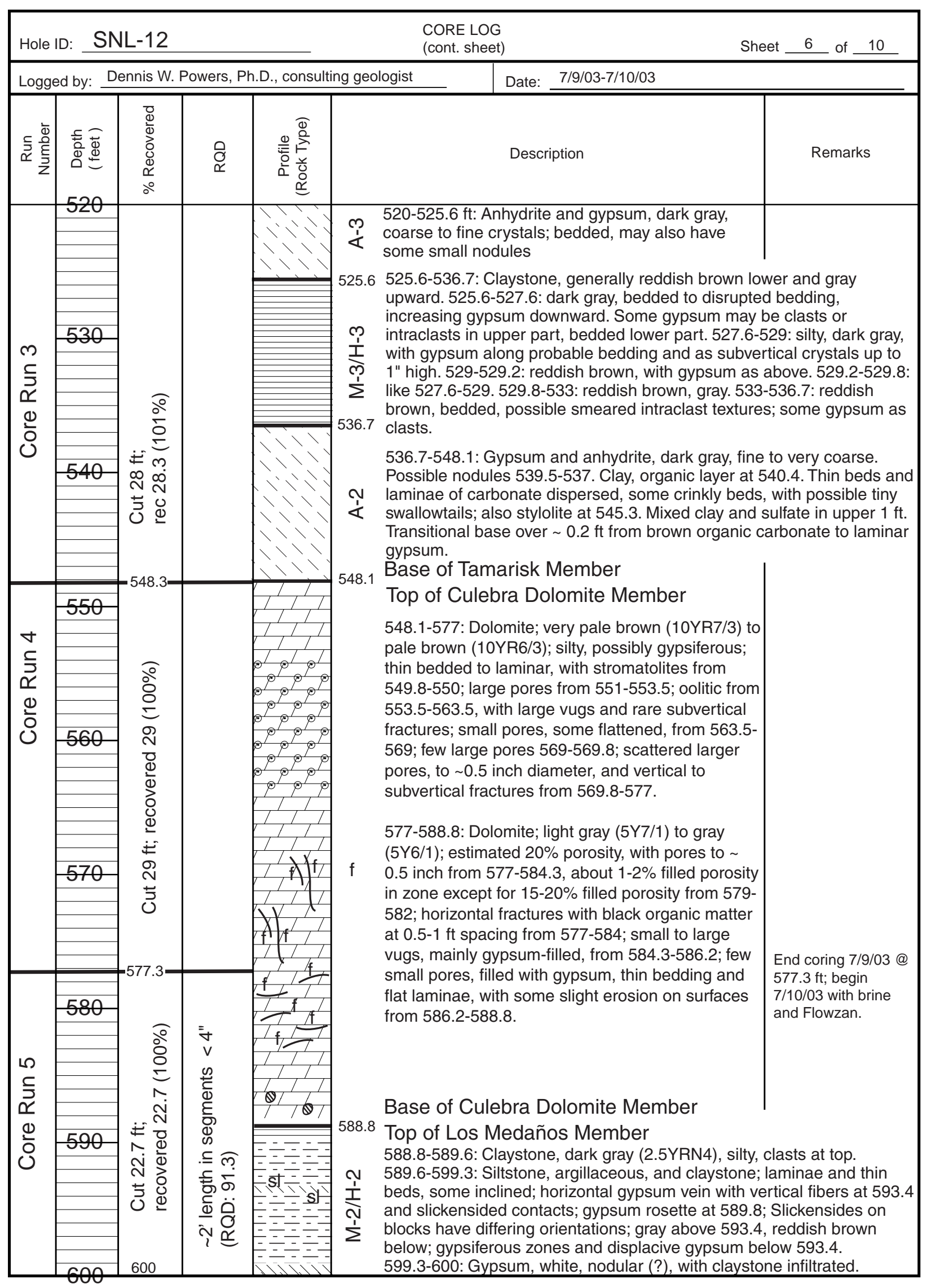




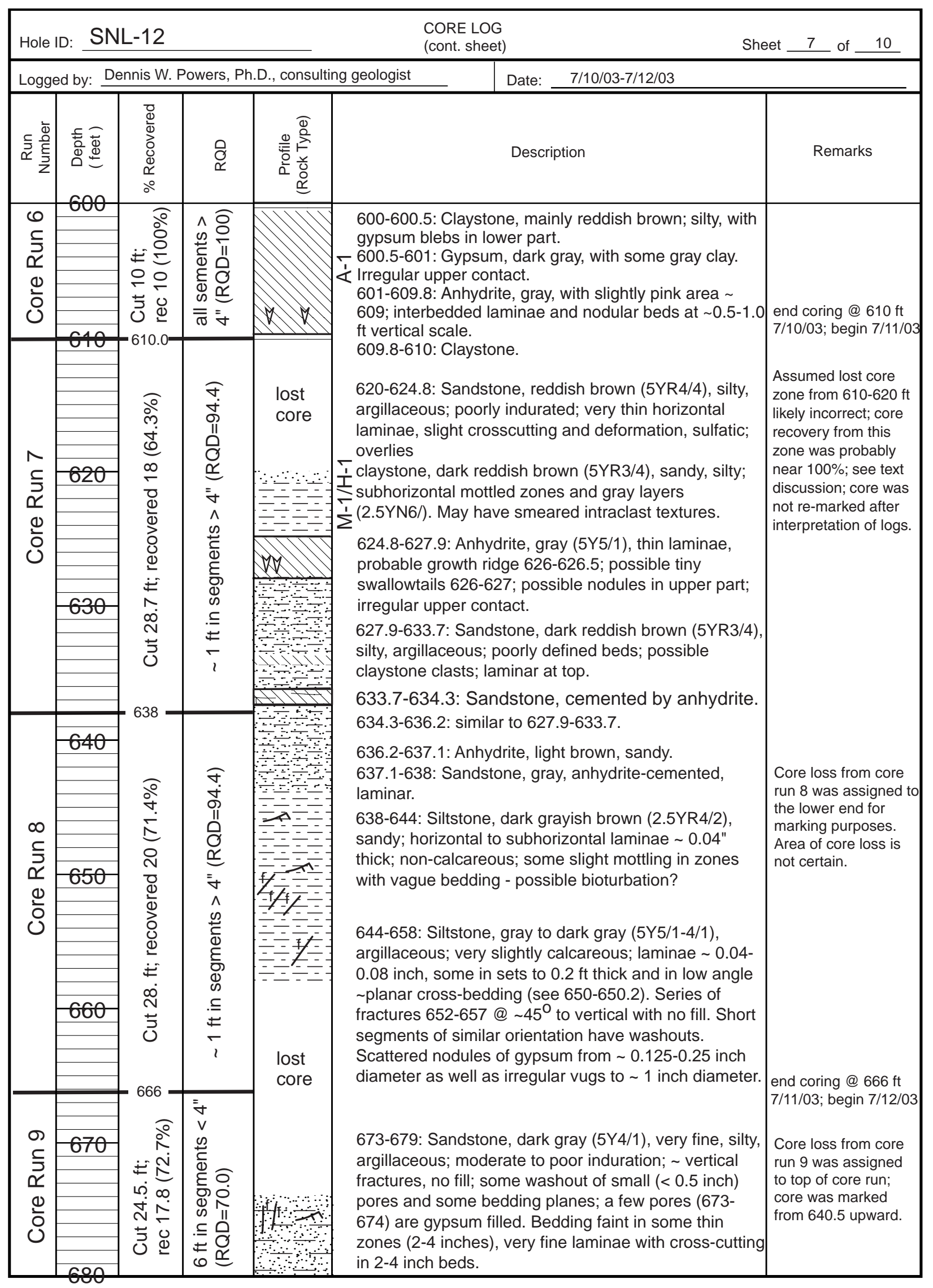




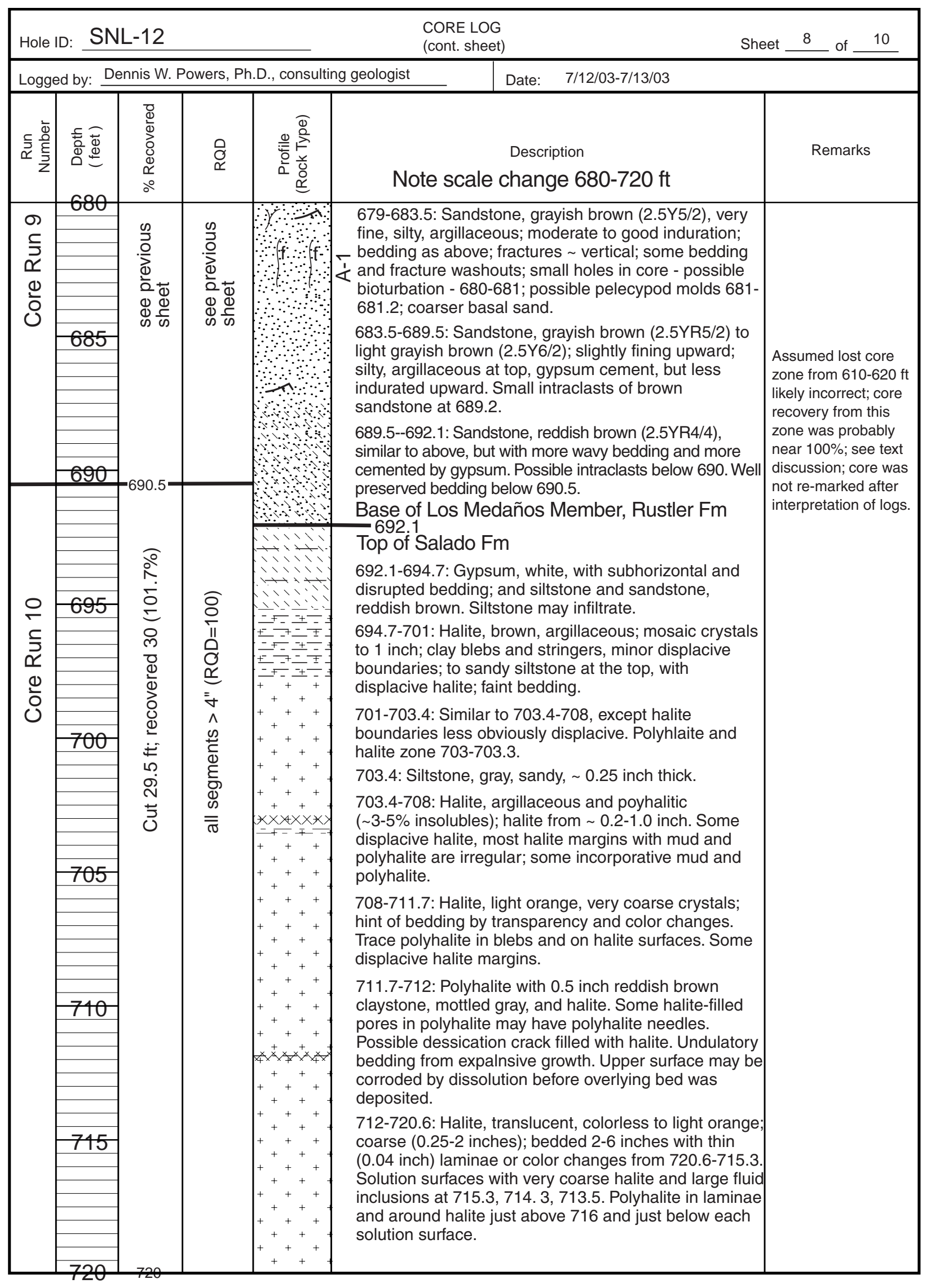




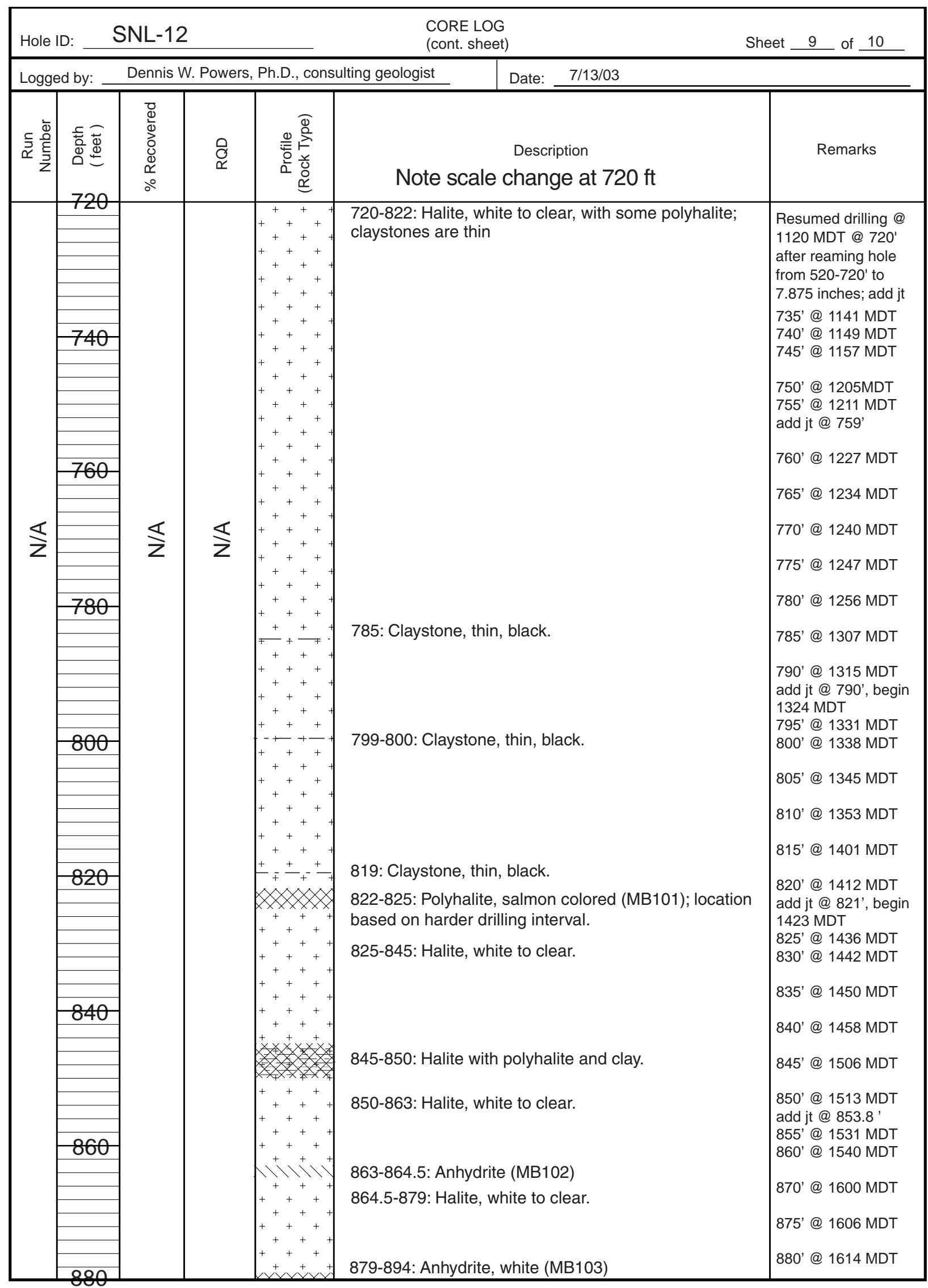


Appendix C Geological Logs

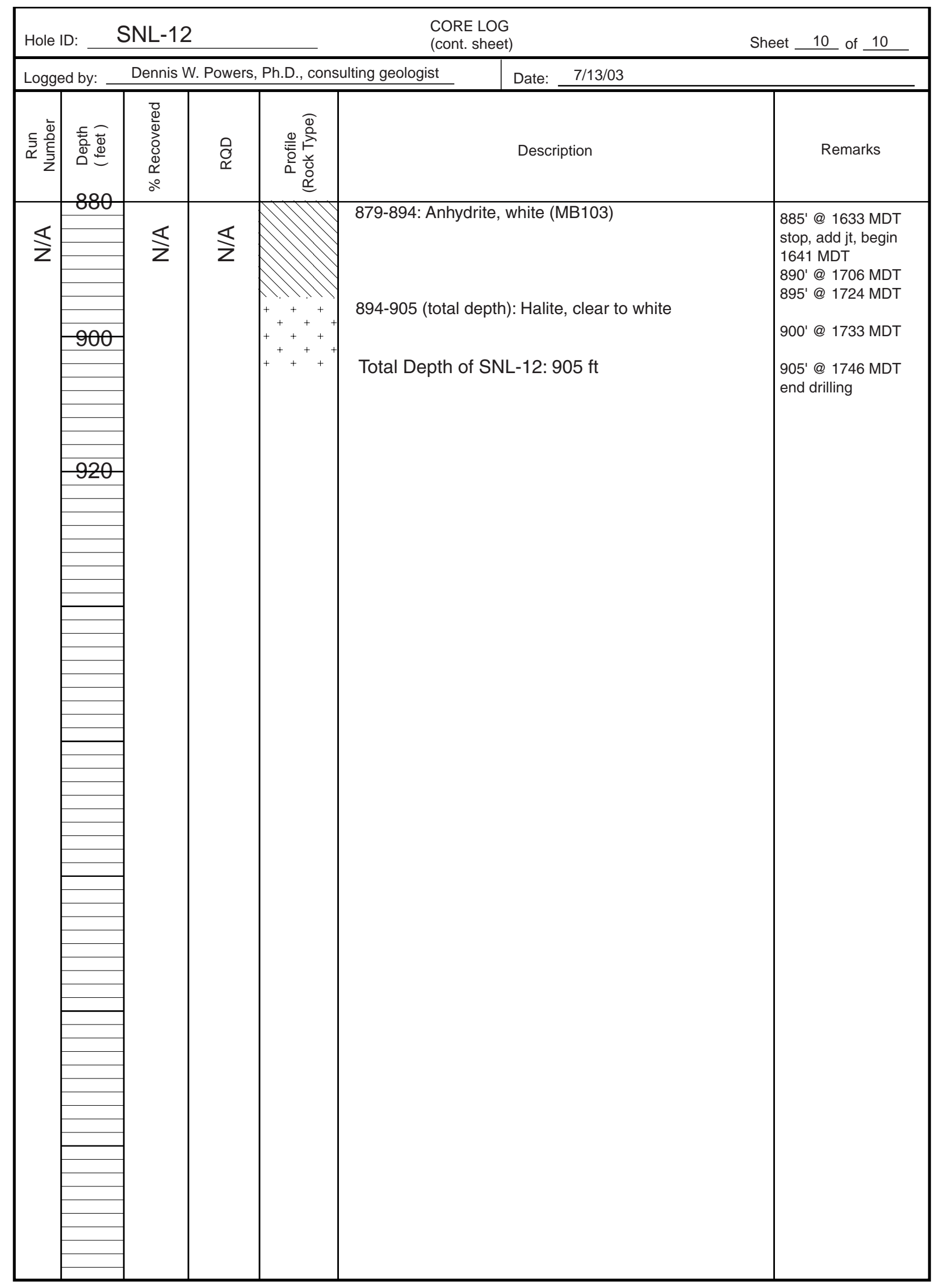




\section{Appendix D Geophysical Logs}

Geophysical logging of SNL-12 was conducted by Raymond Federwisch of Geophysical Logging Services, 6250 Michele Lane, Prescott, AZ 86305 on May 7, 2003, and on May 14, 2003. Copies of the logs are maintained by WRES, Environmental Monitoring and Hydrology Section, for the WIPP Project. A CD-ROM is being retained by the Environmental Monitoring and Hydrology Section that includes:

1) Electronic copies of the logs produced by Geophysical Logging Services using WellCAD vs 3.2,

2) WellCAD Reader to open the electronic logs, and

3) Electronic data files in both .txt and .las formats.

On July 14, 2003, the following geophysical logs were obtained:

- Caliper

- Natural gamma

- Neutron

- Density

- Formation resistivity (see comment below)

- Conductivity (see comment below)

- Spontaneous potential (SP)

- Fluid resistivity (see comment below)

- Fluid temperature
The drillhole was open to about $905 \mathrm{ft}$ bgl at the time of logging. A conductor casing had been emplaced to a depth of $30 \mathrm{ft} \mathrm{bgl}$. The top of the connector on the conductor casing was used as the reference point for depths during drilling and logging. The fluid level at the time of logging was near the top of the connector on the conductor casing, approximately surface level of the drilling pad. The density $\log$ has been included on Figure 2-1 of the main text, but it does not appear to be reliable, as it does not provide the basis for distinguishing between beds of known contrasting density. The neutron log indicates zones through units such as the Culebra, but it is of somewhat uncertain value.

On July 24, 2003, the following geophysical logs were obtained after the drillhole was reamed using a 12.25 inch diameter bit to a depth of about $603 \mathrm{ft} \mathrm{bgl}$ :

- Caliper (0-600.8ft)

This log was used in final calculations of the annulus around the fiberglass casing for completing the well.

Revised files were provided by Geophysical Logging Services August 26, 2003, indicating that fluid resistivity was not valid. Header comments indicated that the conductivity and microresistivity logs were shifted upward by $4 \mathrm{ft}$ due to an error in tool setup during logging on July 14, 2003.

Electronic files for the geophysical logs are maintained for the WIPP Project by the Environmental Monitoring and Hydrology Section, WRES. 


\section{Appendix D Geophysical Logs}

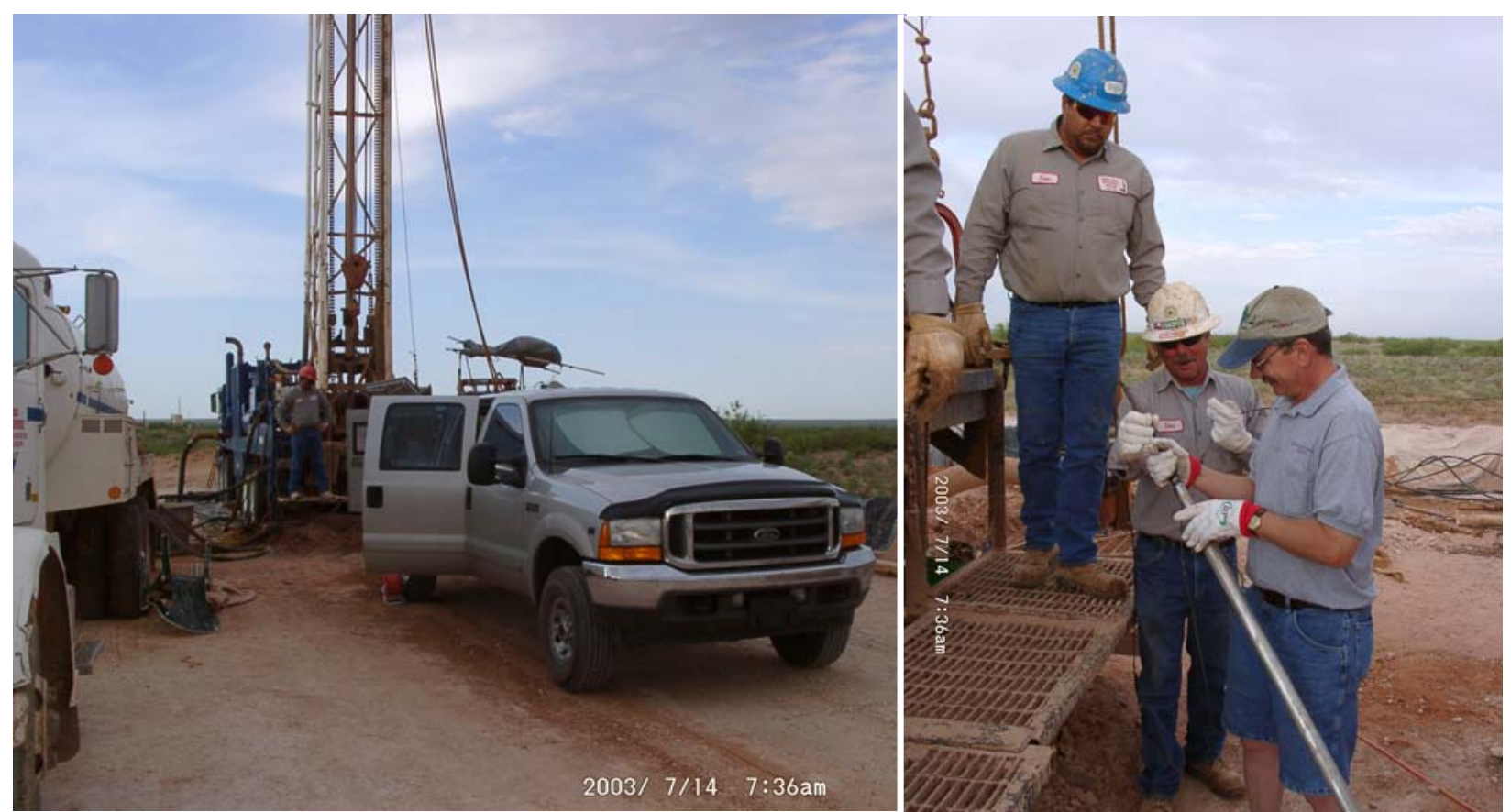

Logging truck from Geophysical Logging Services seting up at SNL-12 for initial logging.

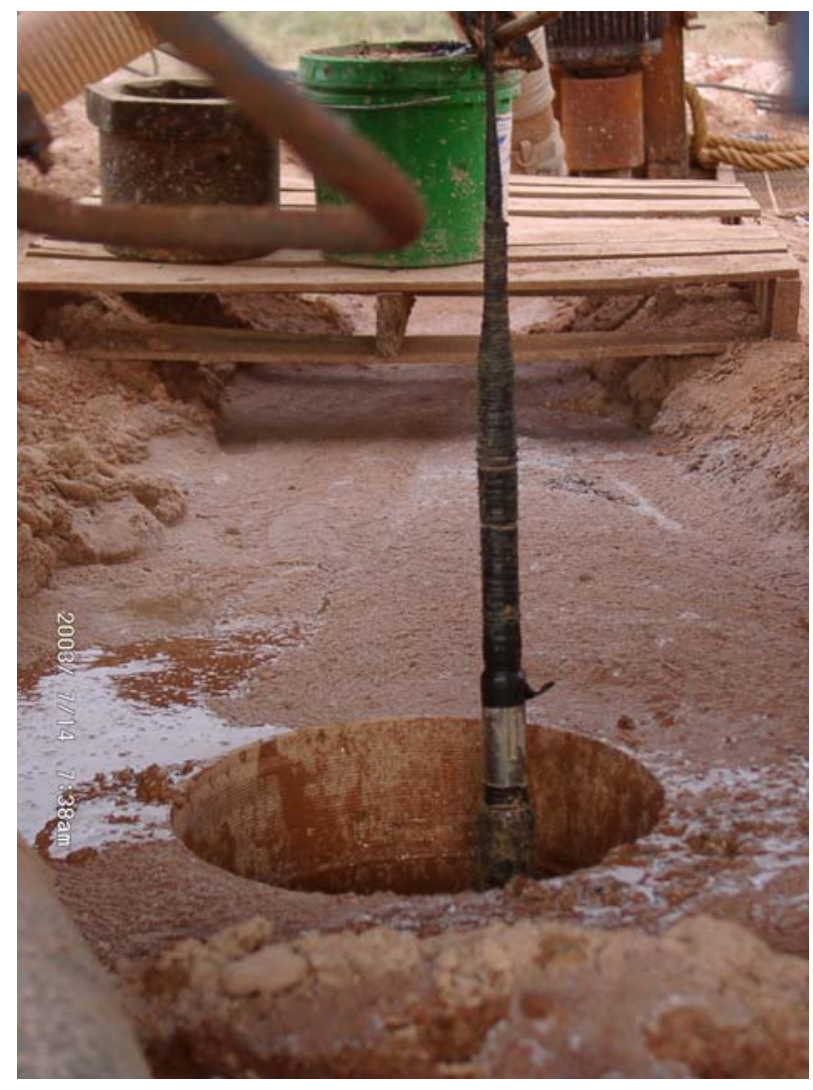

Logging tool at "zero depth" at initial logging of SNL-12.
Raymond Federwisch (r) prepares logging tool for initial logging at SNL-12 as Luis Armendariz (1) and Don Brasil (c) from WTWWS assist.

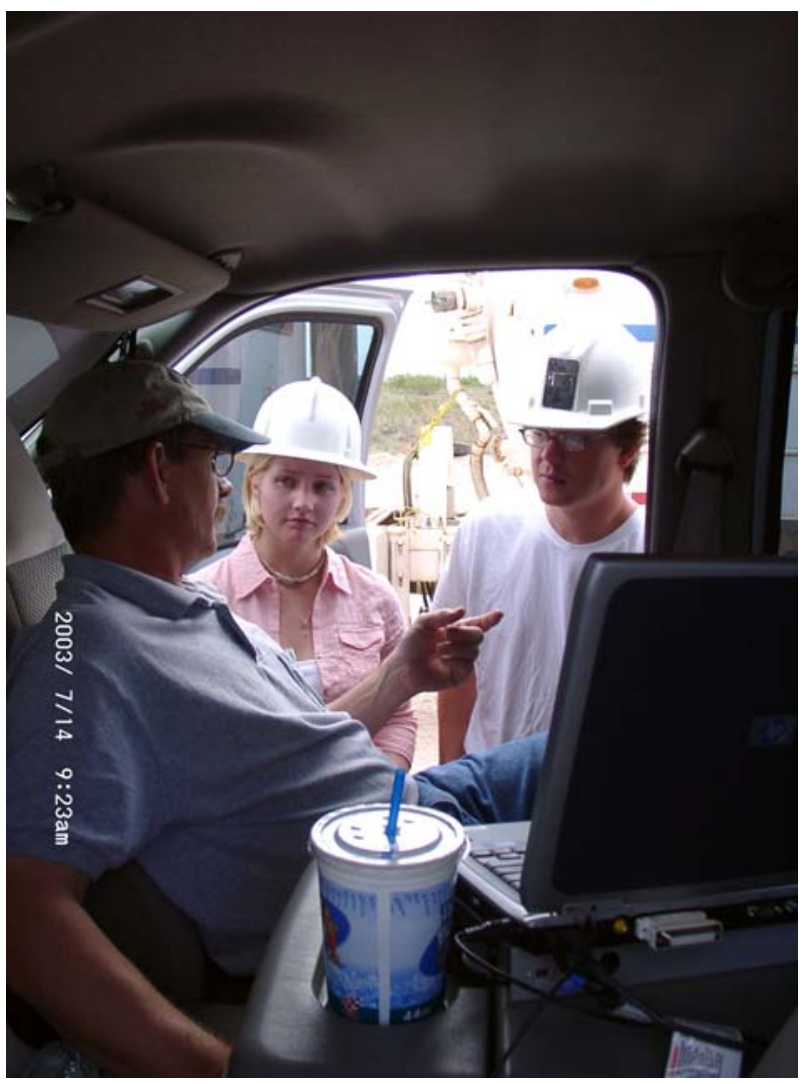

Raymond Federwisch (1) explains logging procedures to Sandia National Laboratories interns Tesha Roberts (c) and Mike McKenna (r). 


\section{Appendix E Permitting and Completion Information}

A case file for SNL-12 (C-2954) containing official documents is maintained by the land management coordinator of the Environmental Monitoring and Hydrology Section (of WRES) for the WIPP Project. Selected documents are reproduced here for ease of access. Originals have been reduced to fit page formats.

As noted in the text, all official correspondence concerning permitting and regulatory matters should refer to the New Mexico State Engineer permit number, C-2954.

Information on management of well-drilling wastes for SNL-12 is included at the end of this appendix. Original files are maintained by WRES. 


\title{
United States Department of the Interior
}

\author{
Bureau of Land Management \\ Carlsbad Field Office \\ 620 E. Greene Street \\ Carlsbad, NM 88220 \\ www.nm.blm.gov
}

N RI:PIS REFEK TO:

NM-109176

2805(080)whs.

\section{RIGHT-OF-WAY RESERVATION}

KNOW ALL MEN BY THESE PRESENTS, that in accordance with section 507 of the Federal Land Policy and Management Act of 1976 (90 Stat. 2781, 43 U.S.C. 1767) that the United States of America acting by and through the U. S. Department of the Interior, Bureau of Land Management, does hereby issue and reserve to the U. S. Department of Energy, Carlsbad Field Office, Waste Isolation Pilot Plant (WIPP), a right-of-way for 1 Ground

Exploration/Monitoring well, for the expressed purpose of hydrological investigations for the U.S. Department of Energy's Waste Isolation Pilot Plant, over the following described real property situated in the County of Eddy, State of New Mexico to wit:

\section{T. 23 S., R. 31 E., NMPM}

Sec. 20: NW1/4SE $1 / 4$.

The well site location contains approximately 0.230 acres (approximately $100^{\prime} \times 100^{\prime}$ ).

A plat showing the right-of-way described above is attached hereto as Exhibit $A$ and made a part hereof.

The right-of-way herein granted and reserved is for the full use of the above described property by the U. S. Department of the Energy, Carlsbad Field Office, WIPP, subject to reasonable rules and regulations of the Secretary of the Interior, and to the following terms. and conditions:

1. The facility will be constructed, operated, and maintained in accordance with the details specified in the application submitted March 6, 2003.

2. The Bureau of Land Management retains the right to occupy and use the right-of-way, provided such occupancy and use will not unreasonably interfere with the rights granted herein. The Bureau of Land Management may, if the Department of Energy, Waste Isolation Pilot Plant agrees, grant rights and privileges for the use of the right-of-way to other compatible users including members of the public and other Government Departments and Agencies, States, and local subdivisions thereof.

3. Department of Energy, Carlsbad Field Office, WIPP, will be responsible for the security and day-to-day operation of the facility.

4. Any resources on lands within the right-of-way shall remain under the jurisdiction of the Bureau of Land Management and may be severed or extracted or disposed of only in accordance with applicable law and regulation of the Secretary of the Interior. The extraction, severance, and disposal of any such resources shall be subject to such stipulations, if any, that the Bureau of Land Management and Department of Energy, Carlsbad Field Office, WIPP, agree are needed to avoid unreasonable interference with the use of the land. 
5. When and if the Department of Energy, Carlsbad Field Office, WIPP, no longer needs this reservation, if jurisdiction is not transferred to another entity, the Department of Energy, Carlsbad Field Office, WIPP, will rehabilitate the land according to the following specifications.

A. All structures, improvements, debris, etc., will be removed.

B. The land will be returned to the original contour.

C. All disturbed surfaces will be reseeded according to Bureau of Land Management specifications. Attached are stipulations for reseeding. Exhibit A.

D. The well shall be properly plugged (See the attached Casing Program Plugging and Abandonment Requirements). Exhibit A-1.

E. Precautions will be taken for all arc and/or gas welding operations. Exhlbit A2.

6. This reservation shall be renewable and shall have a 30-year term, commencing on the date shown below.

Dated this $15^{\text {th }}$ day of April, 2003.

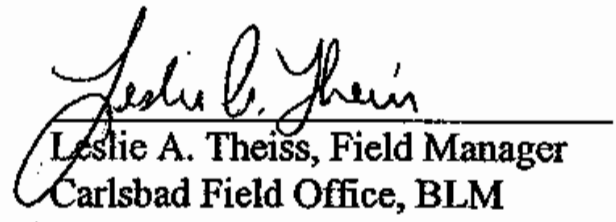


EXHIBIT A

April 15,2003

BLM Serial No.: NM-109176

Company Reference: SNL-12

Seed Mixture 2, for Sandy Sites

The holder shall seed all disturbed areas with the seed mixture listed below. The seed mixture shall be planted in the amounts specified in pounds of pure live seed (PLS)* per acre. There shall be no primary or secondary noxious weeds in the seed mixture. Seed will be tested and the viability testing of seed will be done in accordance with State law(s) and within nine (9) months prior to purchase. Commercial seed will be either certified or reglstered seed. The seed container will be tagged in accordance with State law(s) and available for inspection by the authorized officer.

Seed will be planted using a drili equipped with a depth regulator to ensure proper depth of planting where drilling is possible. The seed mixture will be evenly and uniformly planted over the disturbed area (smaller/heavier seeds have a tendency to drop the bottom of the drill and are planted first). The holder shall take appropriate measures to ensure this does not occur. Where drilling is not possible, seed will be broadcast and the area shall be raked or chained to cover the seed. When broadcasting the seed, the pounds per acre are to be doubled. The seeding will be repeated until a satisfactory stand is established as determined by the authorized officer. Evaluation of growth will not be made before completion of at least one full growing season after seeding.

Species to be planted in pounds of pure live seed* per acre:

Species

Sand dropseed (Sporobolus cryptandrus)

Sand lovegrass (Eragrostis trichodes)

Plains bristlegrass (Setaria macrostachya) $\underline{\mathrm{lb} / \mathrm{acre}}$

1.0

1.0

2.0

*Pounds of pure live seed:

Pounds of seed $\mathbf{x}$ percent purity $\mathbf{x}$ percent germination $=$ pounds pure live seed 
SPECIAL STIPULATIONS (exhibit A-1)

RIGHT-OF-WAY RESERVATION

NM-109176

Casing / Plugging \& Abandonment Requirements

(1) Casing Program

(a) A salt protection string of new or used casing in good condition shall be set in any well which has reached the salt section. Well depth permitting, the casing shall be set not less than one hundred (100) feet below the base of the salt section. If the well does not extend to a depth of at least one hundred (100) feet below the base of the salt section, the casing shall be set at total depth.

(b) The salt protection string shall be cemented with sufficient cement to fill the annular space back of the pipe from the casing seat to the surface or to the bottom of the cellar.

(c) If the cement fails to reach the surface or the bottom of the cellar, the top of the cement shall be located by a temperature, gamma ray or other survey and additional cementing shall be done until the cement is brought to the point required.

(d) The fluid used to mix the cement shall be saturated with the salts common to the zones penetrated and with suitable proportions but not less than one (1) percent of calcium chloride by weight of cement.

(e) Cement shall be allowed to stand a minimum of twelve (12) hours under pressure and a total of twenty-four (24) hours before drilling the plug or initiating tests.

(f) Casing tests shall be made both before and after drilling the plug and below the casing seat. The mud shall be displaced with water and a hydraulic pressure of one thousand $(1000)$ pounds per square inch shall be applied. If a drop of one hundred (100) pounds per 
square inch should occur within thirty (30) minutes, corrective measures shall be applied.

(g) The Bureau of Land Management may require the use of centralizers on the salt protection string when in their judgement the use of such centralizers would offer further protection to the salt section.

(2) Plugging and Abandonment

(a) The wells shall be plugged in a manner and in accordance with rules established by the Bureau of Land Management that will provide a solid cement plug from total depth to the surface.

(b) The fluid used to mix the cement shall be saturated with the salts common to the salt section penetrated and with suitable proportions but not more than three (3) percent of calcium chloride by weight of cement being considered the desired mixture whenever possible. 
NM-109176

Exhibit A-2

The following precautions will be taken for all arc and/or gas welding operations, and operations where oxy-acetylene cutting and brazing are done in a wildland fire environment.

1. At the work site, clear away all flammable vegetation down to mineral soil for a minimum radius of 6 feet around where the welding/cutting will take place. This includes grasses and other vegetative material.

2. While conducting the welding/cutting operations, the operator will have within 25 feet of the welding/cutting site:

Five (5) gallons of water and/or;

A five (5) pound multi-purpose dry fire extinguisher and a round point shovel.

3. After welding/cutting activities are completed, a routine return to the site will be required within 1 hour after the completion of the activity to check for any potential hot material that may start a wildland fire.

Operators and contractors are reminded that they may be held responsible for any wildland fire that starts from welding/cutting operations. This includes all cost for suppressing any wildland fire that starts from these activities. 


\section{NM-109/76}

\section{Survey for the SN L-12/WT S-10 Watex Monitoring Well}

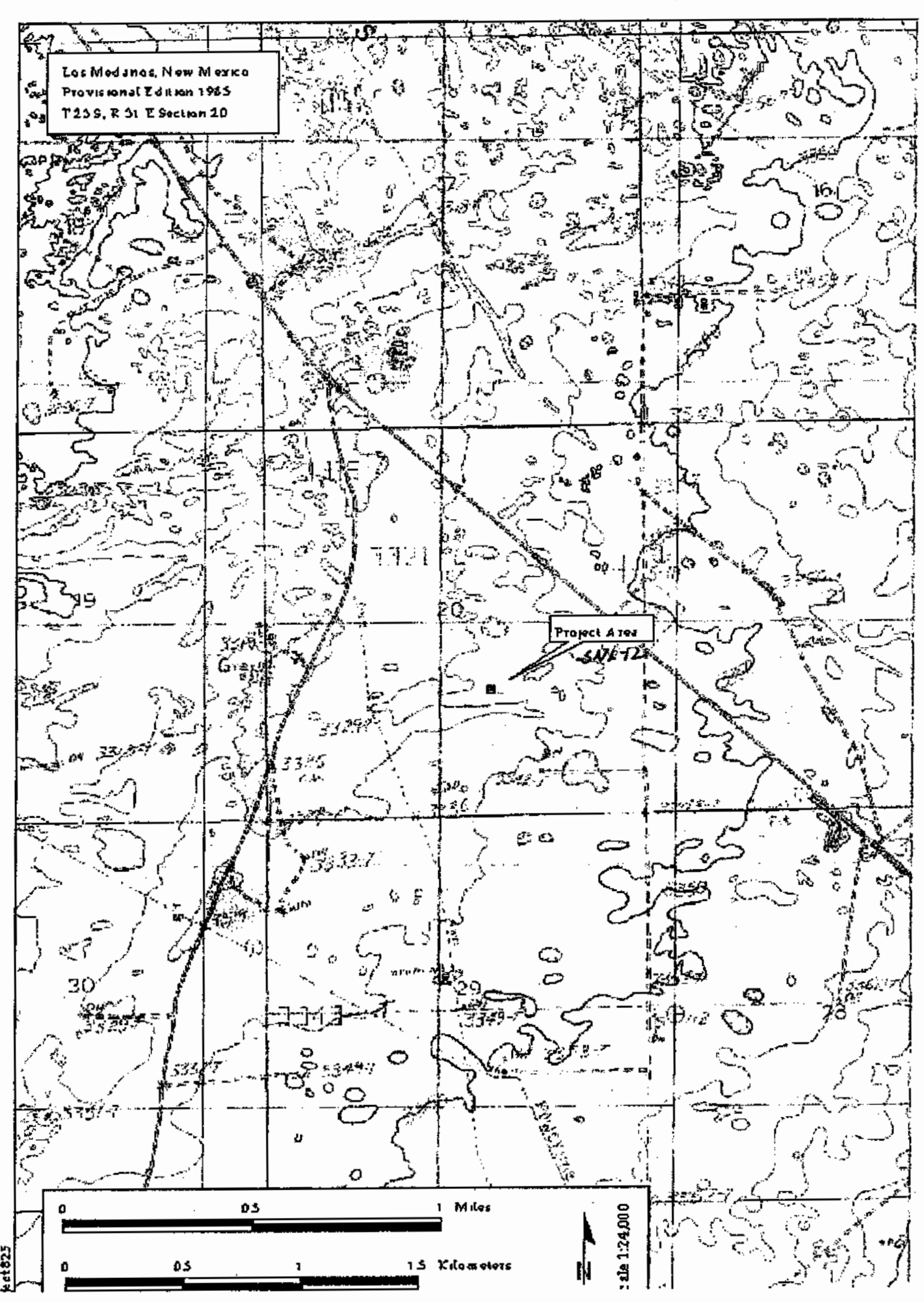




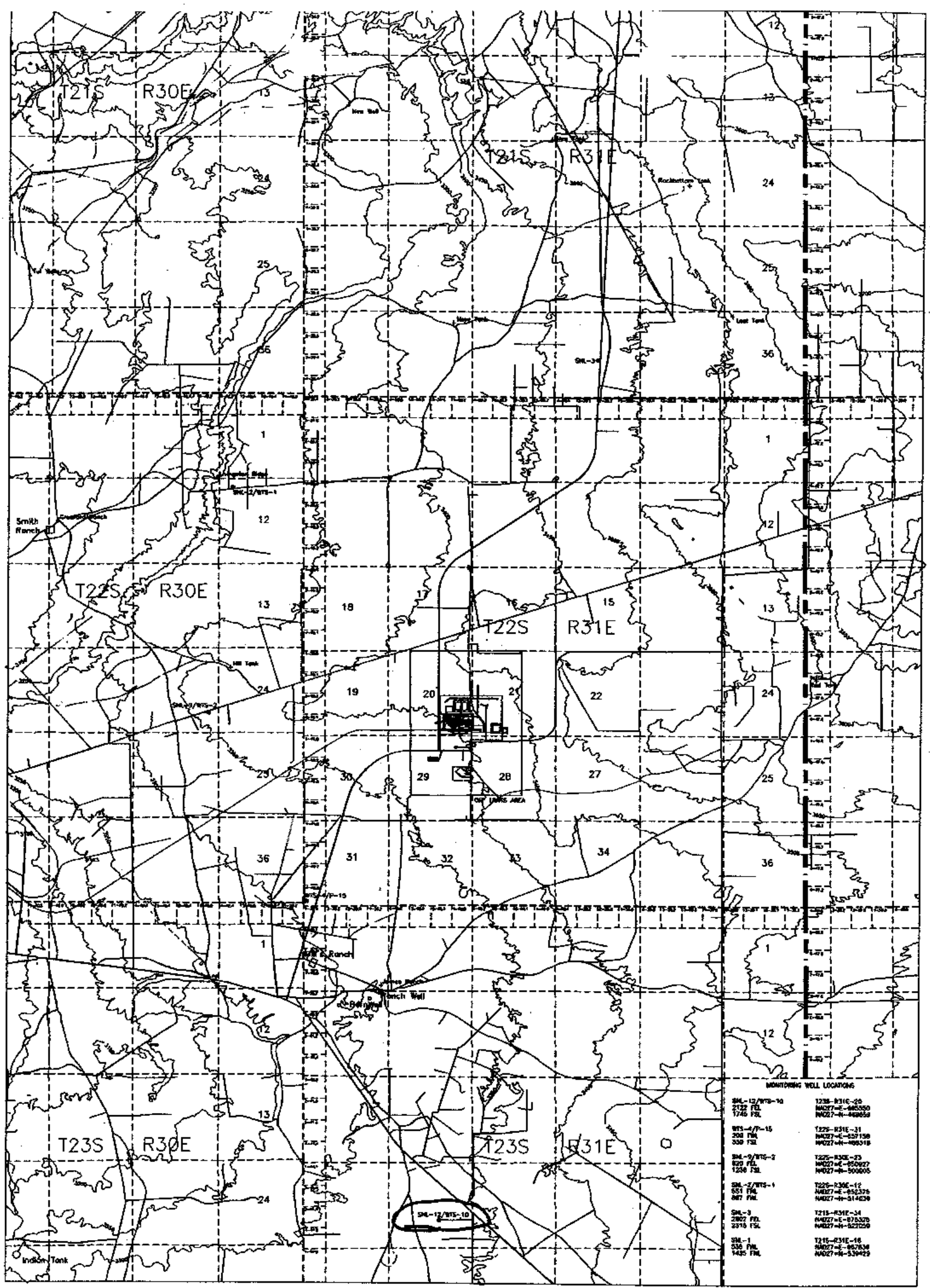


John R. D Antonio, Jr., P.E. state Engineer

Trn Nbr: 259794

File Nbr: C 02954 EXPL

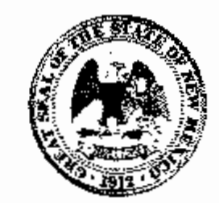

Roswell office 1900 WEST SECOND STREET ROSWELL, NM 88201

\title{
STATE OF NEW MEXICO OFFICE OF THE STATE ENGINEER
}

\author{
Feb. 25, 2003
}

DOUG LYNN

U.S. DEPARTMENT OF ENERGY CARLSBAD FIELD OFFICE, WIPP PO BOX 3090

CARLSBAD, NM 88221-3090

Greetings :

Enclosed is your copy of the Exploratory Permit which has been approved. In accordance with the conditions of approval, the well can only be tested for 10 cumulative days, and the well is to be completed on or before $02 / 25 / 2004$, unless a permit to use the water is acquired from this office.

Sincerely,

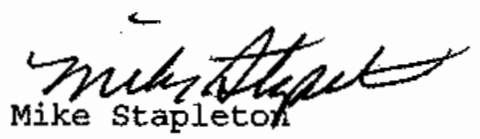

(505) $622-6467$

Enclosure

cC: Santa Fe office

explore 
IMPORTANT - RE HU INSTRUCTIONS ON BACK BEFORE FILL

\section{APPLICATION FOR PERMIT}

To appropriate (explare \& monitor) the Underground Waters of the State ofNew Mexico

Date Received_February 24, 2003

File No. C-2954 Expl.

1. : Name of applicantU.S. Department of Energy, Carisbad Field Office, WIPP

Mailing address P.O. Box 3090, Carlsbađ, New Mexico 88221-3090

City and StateCarlsbad, New Mexico, 88221

2. Source of water supply Artesian - Culebra located in Carlsbad,

(Artesian or shailow water aquifer)

3. The well is to be located in the $S W, 1 / 4 \mathrm{NW} / 4 \mathrm{SE}$ 1/4. Section 20 _Township 23 South

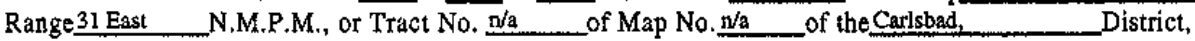
on land owned by State of New Mexico - See Attached Plat of Survey

4. Description of well: name of drillerWest Texas Water Well Service

Outside Diameter of casing 5.5" fiberglass inches; Approximate depth to be drilled 795' bgs feet;

5. Quantity of water to be appropriated and beneficially usedN/A fo $\mathrm{N} / \mathrm{A}$ acre feet, Acreage to be irrigated or place of useN/A

6.

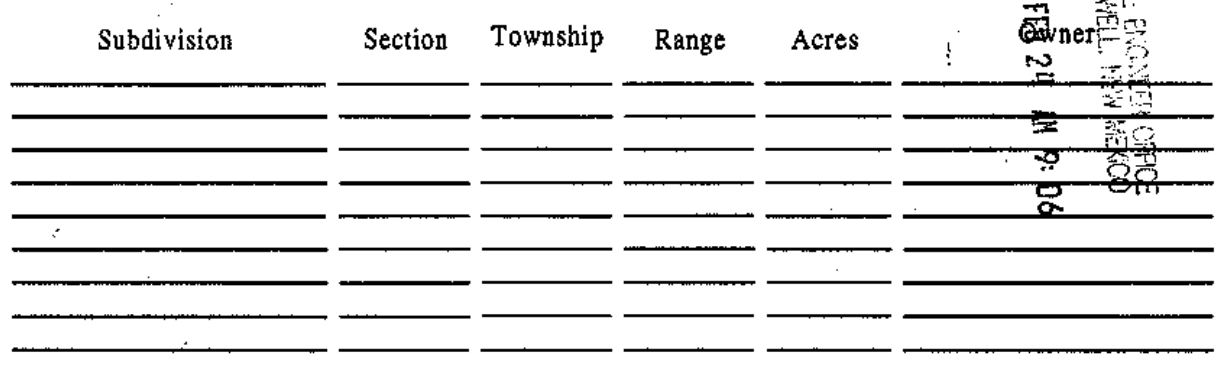

7. Additional statements or explanations This well is to be drilled as an exploration/monitoring well only. It will be drilled to a total depth of $795^{\prime}$ bgs. in order to acquire core samples from Marker Bed 103. After core sample acquisition, the well will be cemented back to the Culebra Dolomite interval @ $975^{\prime}-495^{\prime}$ bgs Casing and cement inspections have been identiffed as thold points pending on site inspections by personnel from the New Mexico Office of the State Engineer. After the initial drilling, pump tests will be conducted to determine the production capacity of the Culebra. These will occur for approximately 96 hours @ 20 gallons per minute. After the completion of the initiaj pump test, this well will be used for routine monitoring purposes (e.g., water level measurements).

1. Ha rold Joh $\mathrm{sen}$, affirm that the foregoing statements are true to the best of my knowledge and belief and that development shall not commence until approval of the permit has been obtained.

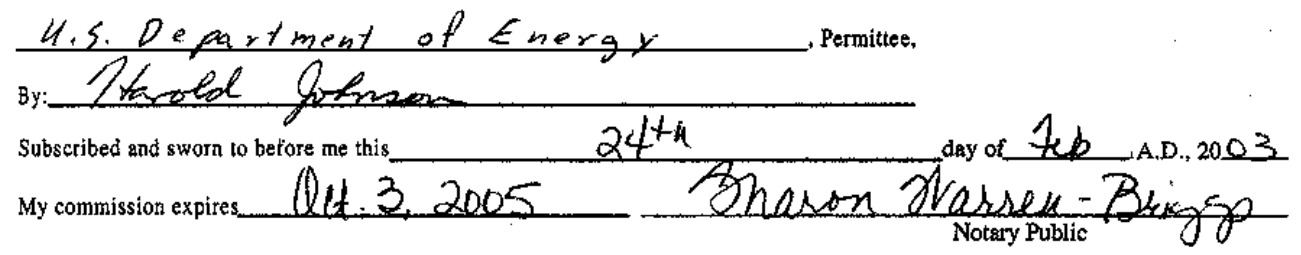


Number of this permit $\quad$ C-2954 EXPL

\section{ACTION OF STATE ENGINEER}

Alter notice pursuant to statute and by authority vested in me, this application is approvedprovicied it is not exercised to the detriment of any others having existing rights; further provided that all rules and regulations of the State Engineer pertaining to the drilling of the following conditions: welis be complied with; and further subject to

the following conditions: see attached conditions

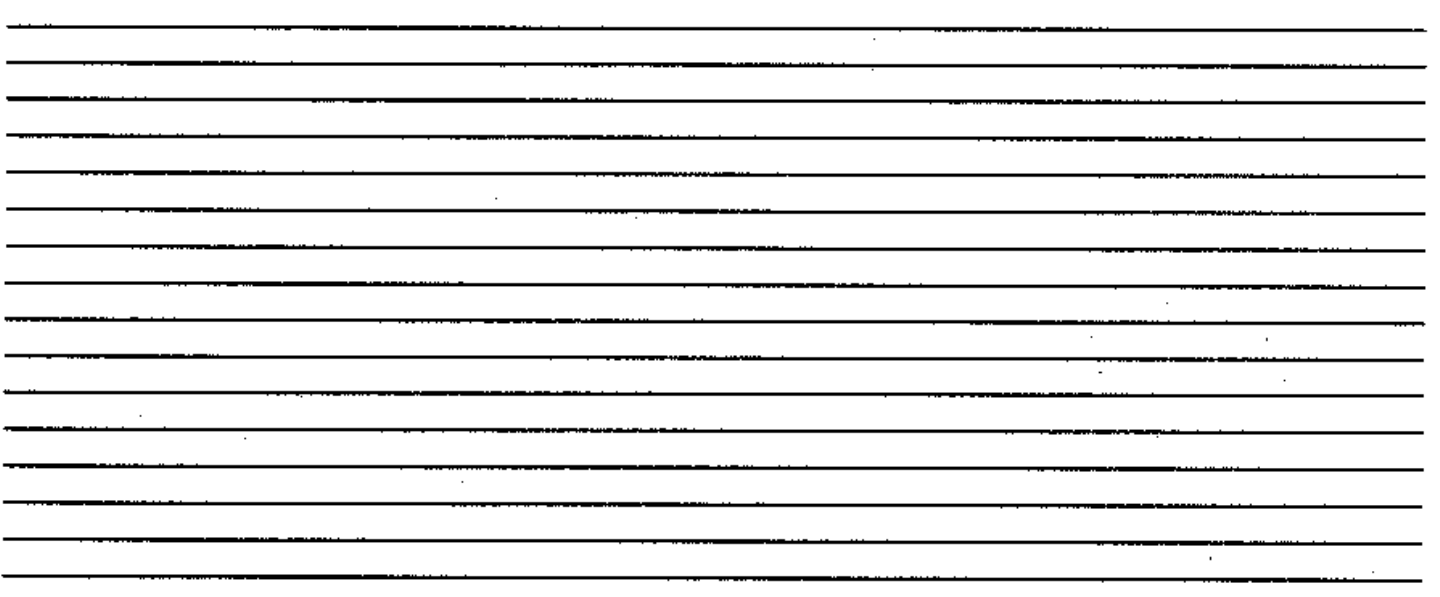
Proof of completion of well stialt befiled on or before___, 20
Proof of application of water to beneficial use shakbe filed on or before , 20

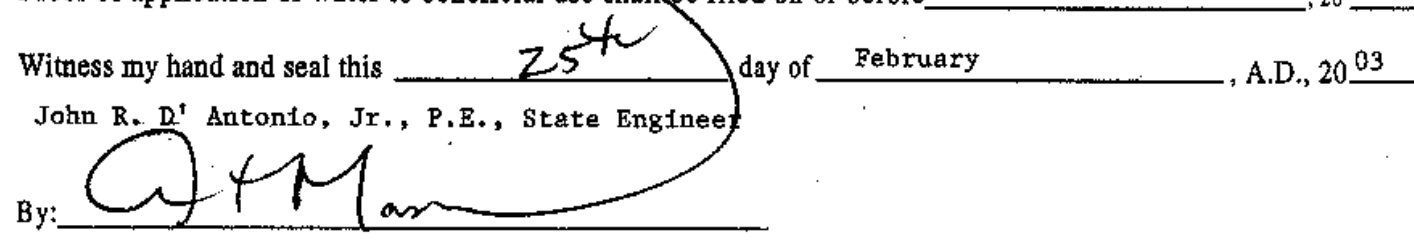

Art Mason, District II Supervisor

\section{INSTRUCTIONS}

This form shall be executed, preferably typewritten, in triplicate and shall be accompanied by a filing fee of $\$ 25.00$. Each of triplicate copies must be properly signed and attested.

A separate application for permit must be filed for each well used.

Secs, 1-4 - Fill out all blanks fully and accurately.

Sec. 5 - Irrigation use shall be stated in acre feet of water per acre per annum to be applied on the land. If for municipal or other purposes, state total quantity in acre feet to be used annually.

Sec. 6 - Describe only the lands to be irrigated or where water will be used. If on unsurveyed lands describe by legal subdivision "as projected" from the nearest govemment survey comers, or describe by metes and bounds and tie survey to some permanent, easily located natural object.

Sec. 7 - If lands are irrigated from any other source, explain in this section. Give any other data necessary to fully describe water right sought. 


\section{NEW MEXICO STATE ENGINEER OFFICE PERMIT TO EXPLORE}

\section{SPECIFIC CONDITIONS OF APPROVAL}

2 The well shall be constructed to artesian well specifications and the state Engineer shall be notified before casing is landed or cemented

B The well shall be drilled by a driller licensed in the state of New Mexico in accordance with Section 72-12-12 New Mexico statutes Annotated.

C Driller's well record must be filed with the State Engineer within 10 days after the well is drilled or driven. Well record forms will be provided by the state Engineer upon request.

C2 No water shall be diverted from this well except for testing purposes which shall not exceed ten (10) cumulative days, and well shall be plugged or capped on or before, unless a permit to use water from this well is acquired from the office of the state Engineer.

LOG The Point of Diversion C 02954 EXPL must be completed and the Well Log filed on or before 02/25/2004.

\section{ACTION OF STATE ENGINEER}

Notice of Intention Rcvd:

Formal Application Rcvd: 02/24/2003

Date Returned_- Correction:

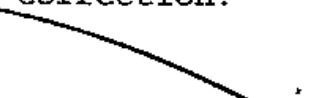

Date Rcvd. Corrected: Pub. of Notice Ordered: Affidavit of Pub. Filed:

This application is approved tovided it is not exercised to the detriment of any others having existing right and is not contrary to the conservation of water in New Mexico nor detrimentah to the public welfare of the state; and further subject to the specific conditions listed previously.

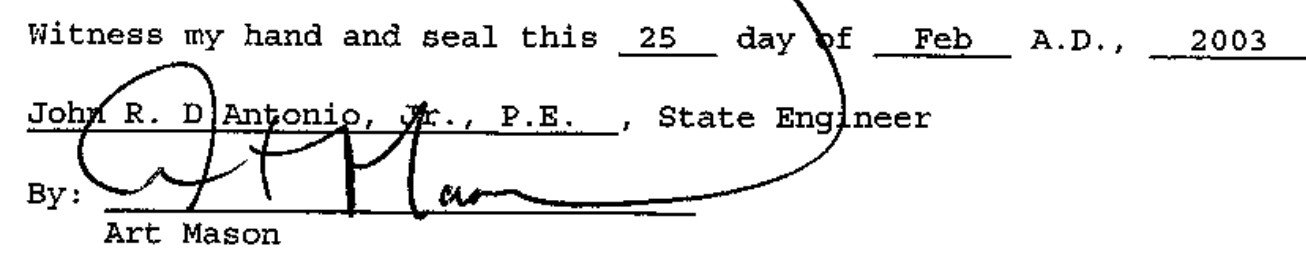


EXHIBIT A FOR: DEPARTMENT OF ENERGY

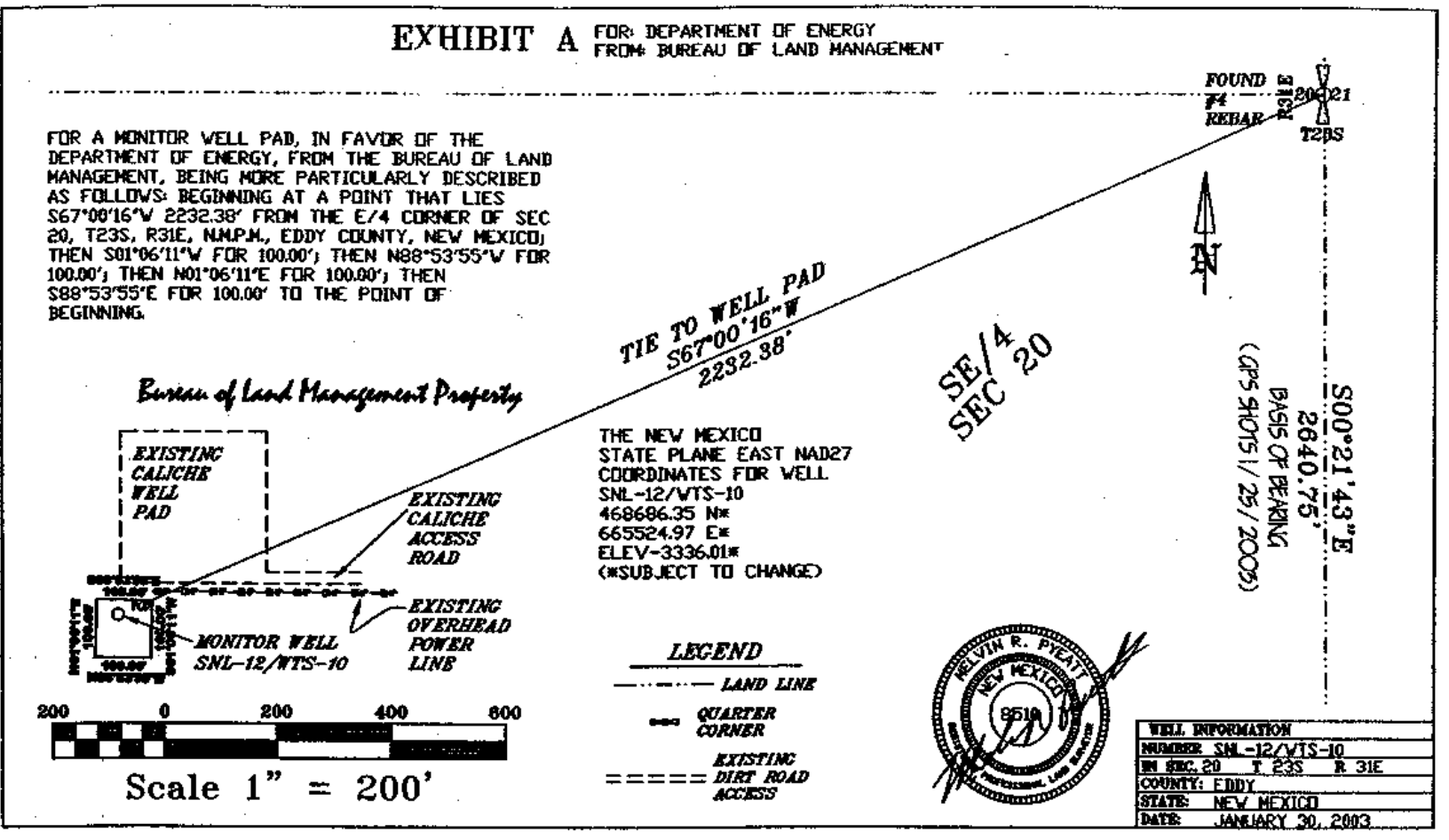

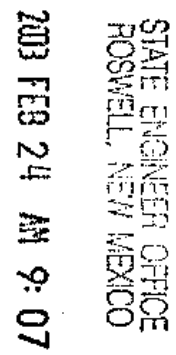


STATE OF NEW MEXICO OFFICE OF THE STATE ENGINEER WELL DRILLER'S LICENSE

This Certifies that . RowiY KaITH

of WEST TEXAS WATER WET SERTICE, ODESSA, TX. has met the requirements of Chapter 75-11-13.1053 NMSA, pertaining to water well drillers in declared underground basins and is hereby granted License No. .................T-1 184..........10 drill water wells of the types described below, in accordance with the stakutes and with the Rules and Reguiations of the State Engineer.

"...ARIESIAN" AND " NOR-ARTESTAN" WHTLS

Witness my hand this ..26

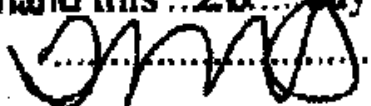
Distrief Suptertisor 20.01

This License Expires ........ OCTOBER 31 ;...2003 


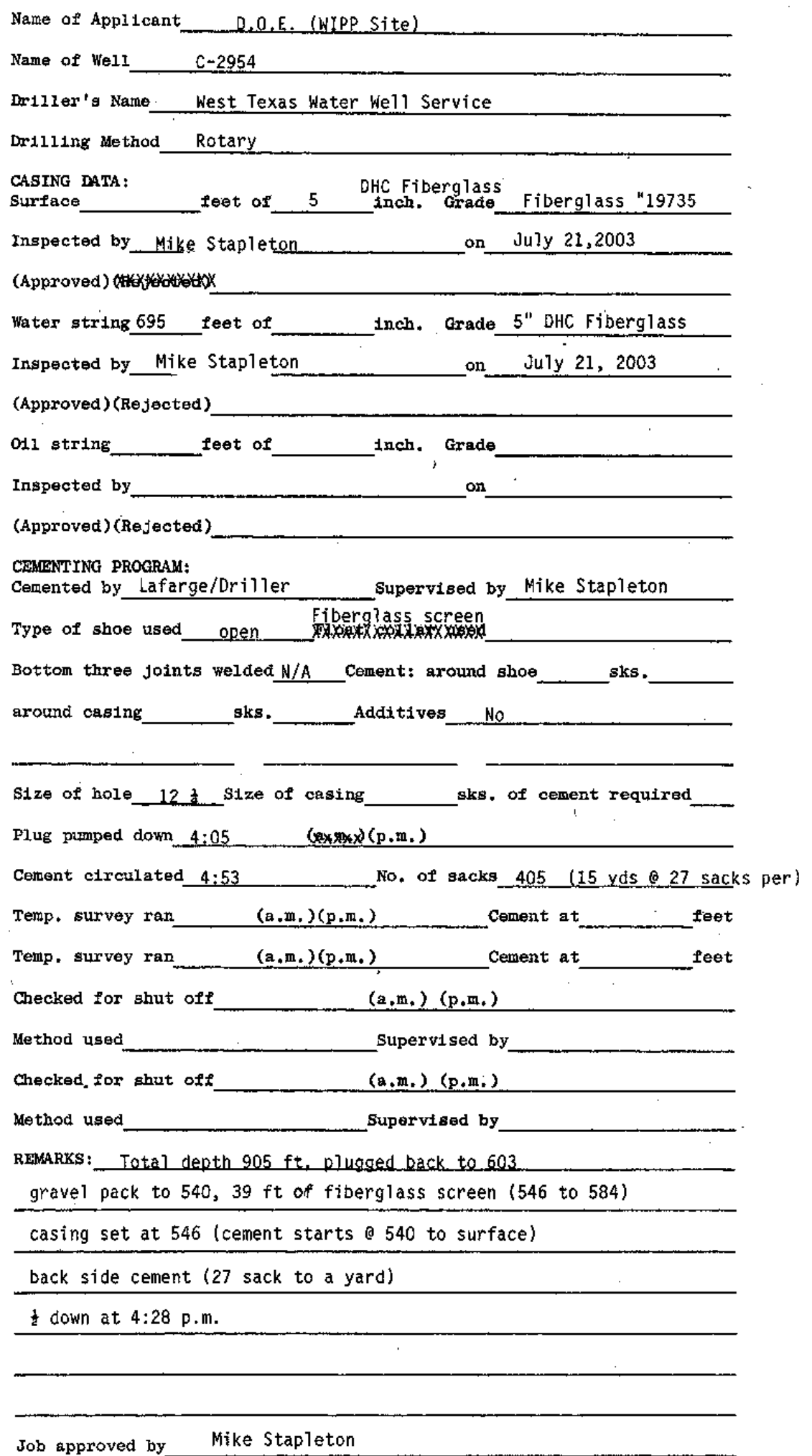

File No. $C=2954$ Location No. 235.31E.20 SwPWSE

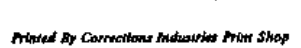


STATE ENGINEER OFFICE

WELL RECORD

Section I. GENERAL INFORMATION

(A) Owner of well

Cirty and State WASEINGTON TRU SOLUTYNS P.0. BOX 2078 Owner's Wel] No. SNL, 12

Well was drilled under Pemil No C-2954 EXPL. CARISBAD, NEW MEXICO 88221
a. $\frac{S W}{N W} / / 4 N$
b. Traet No. N/A of Map No. N/A of the Township 23S Range 31 EAST N.M.P.:
c. Lot No._ of Block No. Subdivision, recorded in EDDY of the County.
d. $X=$ teet, $Y=$ feet, N.M. Coordinate System Zone is the CARLSBAD DISTRICT

(B) Drilling Contractor . WEST TRXAS WATER WELL SERVICE Address 3410 MANKINS ODESSA, TEXAS 79764

Driling Beqan 06-25-03 Completed 07-29-03 Type tools MUD ROTARY Size of hole 12-1/4 in. Elevation of land surfiee or ___ at well is 3336,1 it. Total depth of well 595 Completed well is $\square$ shallow artesian. Depth to water upon completion of well Section 2. PRINCIPAL WATER.BEARING STRATA

\begin{tabular}{|c|c|c|c|c|}
\hline \multicolumn{2}{|c|}{ Depth in Feet } & Thickness & & Estimated Yield \\
\hline From & To & in Foet & Descriptlon of Water-Bcaring Formation & (gallons per minute) \\
\hline 548 & 588 & 40 & $\begin{array}{l}\text { LIGHT BROWN } \\
\text { DOLOMITE CULEBRA FORMATION }\end{array}$ & 23 G.P.M. \\
\hline$\therefore$ & &.. & $\cdot$ & \\
\hline & & . & . & \\
\hline & & & . & \\
\hline
\end{tabular}

Section 3. RECORD OF CASING

\begin{tabular}{|c|c|c|c|c|c|c|c|c|}
\hline \multirow{2}{*}{$\begin{array}{c}\text { Diameter } \\
\text { (inches) }\end{array}$} & \multirow{2}{*}{$\begin{array}{l}\text { Pounds } \\
\text { per foot }\end{array}$} & \multirow{2}{*}{$\begin{array}{l}\text { Thresds } \\
\text { per in. }\end{array}$} & \multicolumn{2}{|c|}{ Depth in Feet } & \multirow{2}{*}{$\begin{array}{c}\text { Length } \\
\text { (feet) }\end{array}$} & \multirow{2}{*}{ Type of Shoo } & \multicolumn{2}{|c|}{ Perforations } \\
\hline & & & Top & Bottom & & & From & To \\
\hline $13-3 / 8$ & 48 & 8 & 2.5 AGL & 30 & $32-1 / 2$ & & & \\
\hline $\begin{array}{c}5^{n} \\
\text { IBERGLASS }\end{array}$ & 3.2 & 4 & $\underline{2}^{\prime}$ AGL & 595 & 597 & $\begin{array}{c}\text { FIBERGLASS CAP } \\
\text { ON BOTTOM }\end{array}$ & 546 & $\begin{array}{l}\text { SCREE } \\
584\end{array}$ \\
\hline & & & & & ' & & & \\
\hline
\end{tabular}

Section 4. RECORD OF MUDDING AND CEMENTING

\begin{tabular}{|c|c|c|c|c|c|}
\hline \multicolumn{2}{|c|}{ Depth in Feet } & \multirow{2}{*}{$\begin{array}{c}\text { Hole } \\
\text { Dismeter }\end{array}$} & \multirow{2}{*}{$\begin{array}{l}\text { Sacks } \\
\text { of Mud }\end{array}$} & \multirow{2}{*}{$\begin{array}{l}\text { Cubic Fecl } \\
\text { of Coment }\end{array}$} & \multirow{2}{*}{ Method of Placement } \\
\hline From & To & & & & \\
\hline 0 & 30 & $\begin{array}{c}18 \\
3-3 / 8 \text { CSG }\end{array}$ & & 34 & PRESSURE \\
\hline 603 & 905 & $7-7 / 8$ & & 102 & TRIMMTE \\
\hline 0 & 540 & $\left\{\begin{array}{l}-174 \text { HOLE } \\
5^{\prime \prime} \mathrm{CSG}\end{array}\right.$ & . & 378 & TRIMMIE \\
\hline
\end{tabular}

Section 5. PLUCGING RECORD

Pluzging Contractor

Address

Plugaing Method

Date Well Plugged.

Plugging approved by:

State Engineer Representative

\begin{tabular}{|c|c|c|c|}
\hline No. & \multicolumn{2}{|c|}{ Depth in Feet } & Cubic Feet \\
\cline { 2 - 4 } & Top Cement \\
\hline 1 & & Bottom & \\
\hline 2 & & & \\
\hline 3 & & & \\
\hline 4 & & & \\
\hline
\end{tabular}

Date Received

FOR USE OF STATE ENGINEER ONLY

Filo

Quad FWL FSL

Filo No, - Usc Locetion No. 


\begin{tabular}{|c|c|c|c|}
\hline \multicolumn{2}{|c|}{ Depth in Feet } & \multirow{2}{*}{$\begin{array}{c}\text { Thickness } \\
\text { in Feet }\end{array}$} & \multirow[b]{2}{*}{ Color and Type of Material Encountered } \\
\hline From & To & & \\
\hline 0 & 10 & 10 & CONSTRUCTION FILL \& BROWN SAND \\
\hline 10 & 18 & 8 & WHITE CALICHE (MESCALERO) \\
\hline 18 & 44 & 26 & $\begin{array}{l}\text { REDDISH BROWN CALCAREOUS SANDSTONE \& CLAYSTONE } \\
\text { (GATUNA FORMATION) }\end{array}$ \\
\hline 44 & 180 & 136 & $\begin{array}{l}\text { REDDISH BROWN CALCAREOUS SANDY SILTSTONE \& SILTY } \\
\text { CLAYSTONE (MIDDLE DEWEY LAKE FORMATION) }\end{array}$ \\
\hline 180 & 372 & 192 & $\begin{array}{c}\text { REDDISH BROWN GYPSIEEROUS SANDY SILISTONE \& SILTY } \\
\text { CLAYSTONE (LOWER DEWEY LAKE FORMATION) }\end{array}$ \\
\hline 372 & 432 & 60 & $\begin{array}{l}\text { WHITE GYPSUM BEDS WITH INTERMEIDATE GRAY TO REDDISH } \\
\text { BROWN CLAYSTONE (FORTY-NINER MEMBER OF RUSTLER FORMATION) } \\
\text { S }\end{array}$ \\
\hline 432 & 460 & 28 & $\begin{array}{l}\text { WHITE TO GRAYISH BROWN GYPSIFEROUS DOLOMITE } \\
\text { (MAGENTA DOLOMITE MENBER OF RUSTLER FORMATION) }\end{array}$ \\
\hline 460 & 548.1 & 88.1 & $\begin{array}{l}\text { WHITE GYPSUM BEDS WITH INTERMEDIATE GRAY TO REDDISH } \\
\text { BROWN CLAYSTONE (TAMARISK MEMBER OF THE RUSTLER FORMATION) } \\
\end{array}$ \\
\hline 548.1 & 588.8 & 40.7 & $\begin{array}{l}\text { LIGHT BROWN DOLOMITE } \\
\text { (CULEBRA DOLOMTTE MEMBER OF THE RUSTLER FORMATION) }\end{array}$ \\
\hline 588.8 & 600.5 & 11.7 & $\begin{array}{l}\text { DARK GRAY TO REDDISH BROWN GYPSIFTROUS CLAYSTONE } \\
\text { (IJPPER LOS MEDANOS MEMBER OF THE RUSTLLER FORMATYON) }\end{array}$ \\
\hline 600.5 & 609.8 & 9.3 & $\begin{array}{l}\text { WHITE ANHYDRITE \& GYPSUM } \\
\text { (UPPER LOS MEDANOS MEMBER OF THE RUSTLER FORMATION) }\end{array}$ \\
\hline 609.8 & 692.1 & $82.3 \mathrm{SOM}$ & $\begin{array}{l}\text { DARK GRAY TO REDDISH BROWN VERY FINE SANDSTONE \& STLTSTONE, } \\
\text { GYPSUM (LOWER LOS MEDANOS MEMBER OF THE RUSTLER FORMATTON) }\end{array}$ \\
\hline 692.1 & 822 & 129.9 & $\begin{array}{c}\text { CLEAR TO WHITE COARSE HALITE WITH INTERBEDDED ANHYDRITE \& } \\
\text { POLYHALITE (UPPER SALADO FORMATION) }\end{array}$ \\
\hline 822 & 825 & 3 & $\begin{array}{l}\text { POLYHALITE, SALMON COLORED } \\
\text { (MARKER BED 101, UPPER SALADO FORMATION) }\end{array}$ \\
\hline 825 & 863 & 38 & WLERR TO WHITE EALITE, SLIGRTYY ARGILLACEOUS \& POLYHALITIC \\
\hline 863 & 864.5 & 1.5 & $\begin{array}{l}\text { ANHYDRITE, WHITE } \\
\text { (MARKER BED } 102 \text {, UPPER SALADO FORMATION) }\end{array}$ \\
\hline 864.5: & 879 & 14.5 & $\begin{array}{l}\text { BALITE, CLEAR TO WHITE } \\
\text { (UPPER SALADO FORMATION) } \\
\end{array}$ \\
\hline 879 & 894 & 15 & $\begin{array}{l}\text { ANHYDRITE, WHITE } \\
\text { (MARKER BED } 103, \text { UPPER SALADO FORMATYON) }\end{array}$ \\
\hline 894 & 905 & 11 & $\begin{array}{l}\text { EALITE, CLEAR TO WHITE } \\
\text { (UPPER SALADO FORMATION) } \\
\end{array}$ \\
\hline$\because$ & & & \\
\hline & & & \\
\hline & & & \\
\hline & & & \\
\hline & & & \\
\hline & & & \\
\hline
\end{tabular}

Section 7. REMARKS AND ADDITIONAL INFORMATION

The undersigned hereby certifles that, to the best of his knowledge and belief, the-fentrompas a true and correchecord of the above described hole.

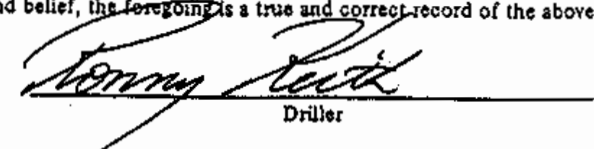

INSTRUCTIONS: This form should be executed in triplteate, preferably typewrften, and submitted to the appropriate district of fice of the State Eneineer. All sections, except Section S, shall be answered as completely and accurately as possible when any well is drilled, repaired or deepened. When this form is used as a pluesing record, only Section $10^{\circ}$ id Section 5 need be completed. 


\section{CONTROLLED RECOVERY, INC.}

P.O. Box 388 - Mobbs, New Mexico 88241-0388

(505) 393-1079

개 to

Mddress

Company/Generator West Tx acateruid Serv. Lease Name WIPP SNL \#传?

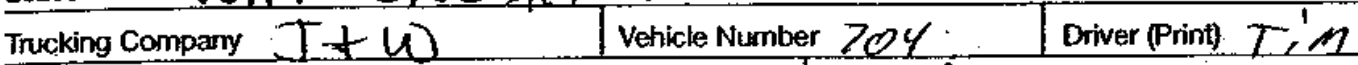

Date $8-4-03$

Time $5: 25$

a.m. $/ 6 . \mathrm{m}$.

Type of Material

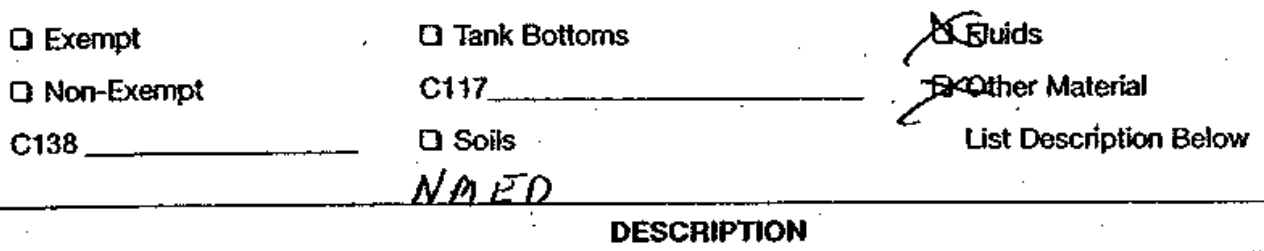

\section{Moiniterinw well Eluit}

Volume of Material
$\square$ Wash Out

C Call Out

O After Hours

Debris Charge

This statement applicable to exempt waste oniy.

I represent and warrant that the wastes are: generated from ofl and gas exploration and production operations: exempt from Resource

Conservation and Recover Act (RCRA) Subtitle C Regulations; and not mixed with non-exempt wastes.

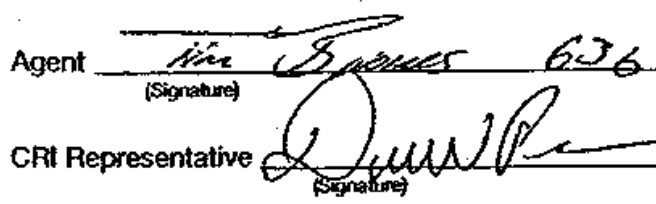

TANK BOTTOMS

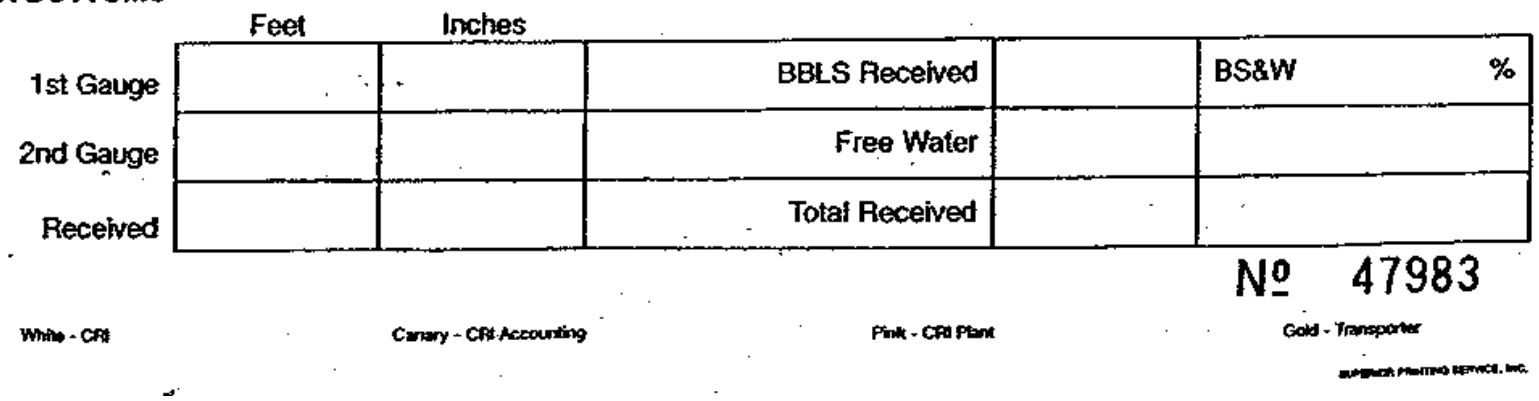




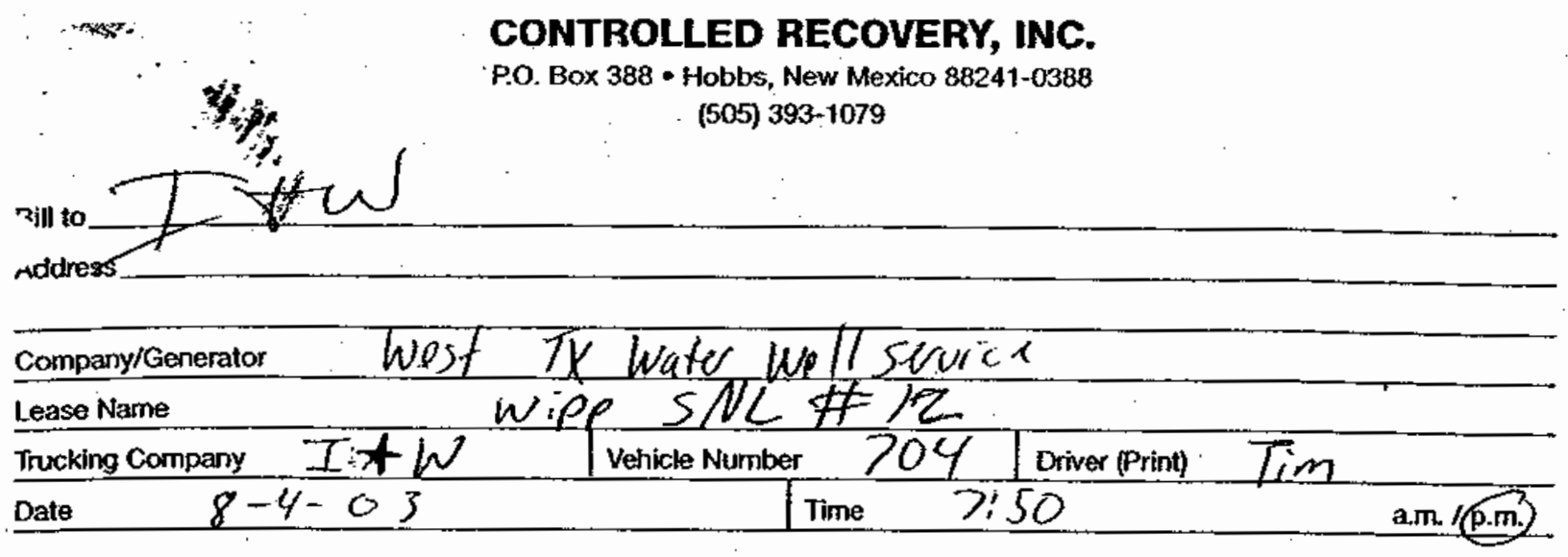

Type of Material

\begin{tabular}{|c|c|c|}
\hline a Exempt & U Tank Bottorns & XFluids \\
\hline D Non-Exempt & C117_ & GOther Material \\
\hline $\mathrm{C} 138$ & $\begin{array}{l}\square \text { Solis } \\
\quad N M E D\end{array}$ & List Description Below \\
\hline
\end{tabular}

\begin{tabular}{|c|c|c|c|}
\hline Volume of Material & $\mathscr{E}_{\text {Bbls. }}$ & 0 Yard. & 6 trallons 5 \\
\hline D Wash Out & 口 Call Out & After Hours & O Debris Charge \\
\hline
\end{tabular}

This statement applicable to exempt waste. only.

1 represent and warrant that the wastes are: generated from oil and gas exploration and production operations: exempt from Resounce Conservation and Recover Act (ACFA) Subtitle C Regulations; and not mixed with nor-exempt wastes.

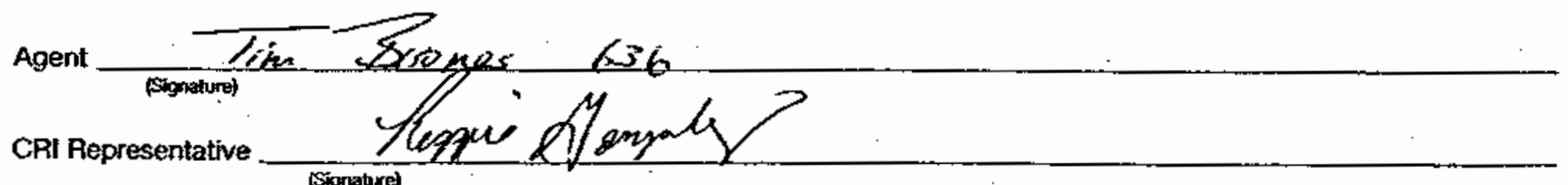

\section{TANK BOTTOMS}

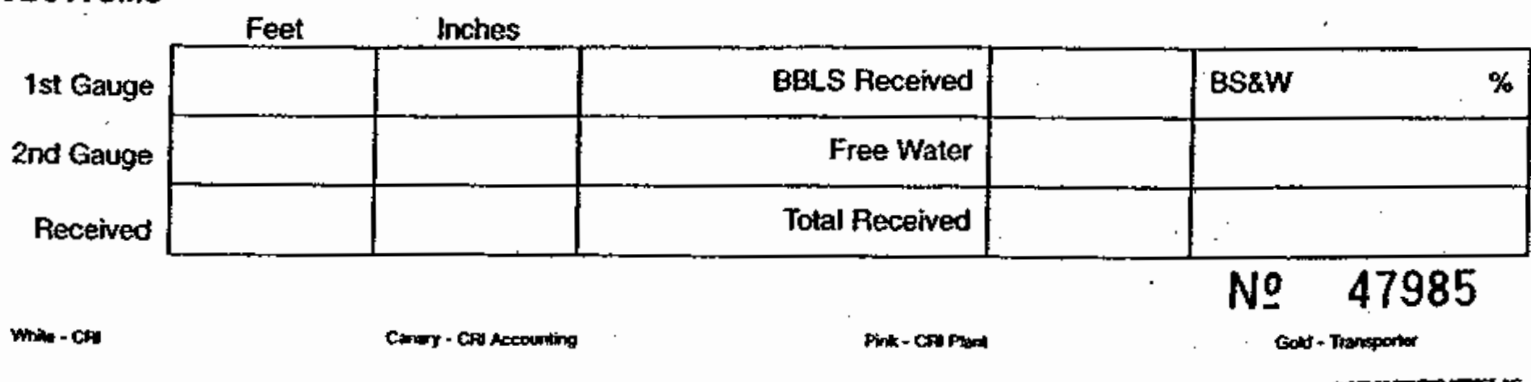


CONTROLLED RECOVERY, INC.

P.O. Box 388 - Hobbs, New Mexico 88241-0388

(505) 393-1079

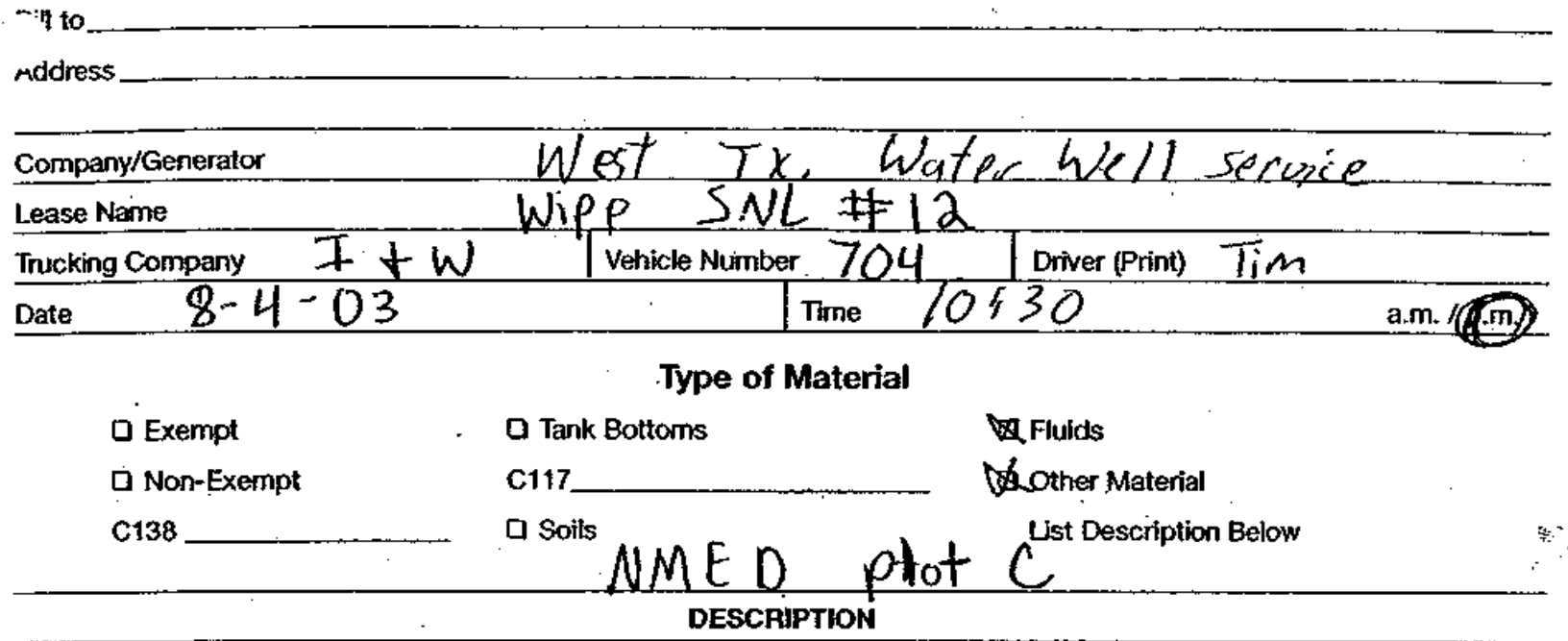

Well fluid

\begin{tabular}{|c|c|c|c|}
\hline Volume of Material & двыs. $12(2)$ & a Yard. & Q Gallions 5,280 \\
\hline D Wash Out & Q Cail Out & 0 After Hours & a Debris Charge \\
\hline
\end{tabular}

This statement applicable to exempt waste only.

I represent and warrant that the wastes are: generated from oil and gas exploration and production operations: exempt from Resource

Conservation and Recover Act (RCPA) Subtitle $C$ Regulations; and not mixed with non-exenpt wastes.

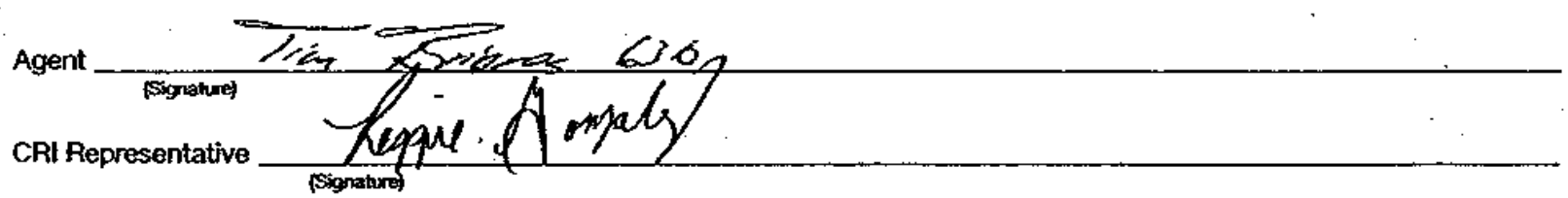

\section{TANK BOTTOMS}

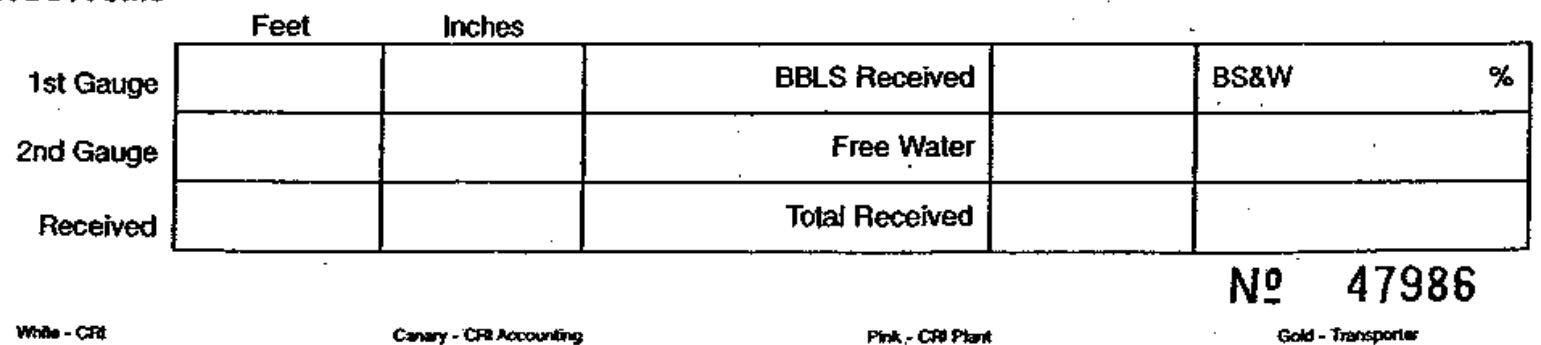




\section{Dennis W. Powers, Ph. D. Consulting Geologist}

July 28, 2003

\section{Ron Richardson}

Field Lead

WRES

\author{
Rick Beauheim \\ Hydrology Lead \\ Sandia National Laboratories
}

\section{Re: Screen Interval for Culebra Dolomite Member in SNL-12}

Our discussions regarding the Culebra Dolomite Member in SNL-12 indicate that the best interval to screen is from 584-546 ft below the top of the permanent conductor casing. This decision is based on geophysical logs completed on July 14, 2003 (see attached figure).

These are the factors we considered in this decision for SNL-12:

- The Culebra interval, as indicated by the natural gamma geophysical log, is from 587-547 $\mathrm{ft}$ below the top of the temporary conductor casing. This interval is $40 \mathrm{ft}$ thick, which is more than the average around the WIPP site. Recovered cores from the Culebra also show a consistent depth and thickness for the Culebra.

- The screened or slotted section of a single casing joint is $\sim 27 \mathrm{ft}$ long. A shorter slotted casing, about $10 \mathrm{ft}$ long, added to the longer joint provides a total screened interval of $38 \mathrm{ft}$. This will provide a screened interval that will incorporate all but the base of the Culebra.

- The core, although incomplete below the Culebra, indicated that the laminated claystone immediately underlying the Culebra behaves somewhat plastically, and the screened interval should be kept above this zone to prevent it from squeezing into the slots.

- Core and geophysical logs above the Culebra indicate the anhydrite/gypsum units are intact and separate the Culebra from the Tamarisk Member mudstone (M-3) by $11 \mathrm{ft}$.

- There is no indication of halite in the mudstone unit (M-2) below the Culebra and above the anhydrite (A-1) about $13 \mathrm{ft}$ below the Culebra.

By placing the bottom of the screened interval $584 \mathrm{ft}$ below the top of the conductor, the mudstone below the Culebra should be isolated from squeezing into the screens. The top of the screened interval at $546 \mathrm{ft}$ should be isolated from the Tamarisk Member mudstone. The top of the sand/gravel pack around the screen should not be higher than about $540 \mathrm{ft}$ below the top of the temporary casing location to prevent circulation into M-3. It can range from about 545-540 ft below the conductor casing top.

To provide adequate space below the screened interval for pumping, a minimum $10 \mathrm{ft}$ long blank casing should be added below the screened casing. The lower part of the hole, as it currently exists, should be cemented up into the anhydrite unit (A-1) with top of cement in the interval from 600-608 ft below the top of the conductor casing to minimize circulation into the lower Los Medaños Member, even though there is no evidence of halite in M-1/H-1 at SNL-12.

I believe this letter summarizes our discussions and presents the hydrological and geological justification for setting the screened interval and preparing SNL-12 for completion.

Sincerely,

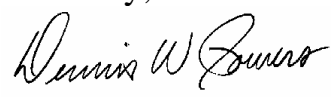

Dennis W. Powers 


\section{Dennis W. Powers, Ph. D. Consulting Geologist}

Partial Geophysical Log of SNL-I2

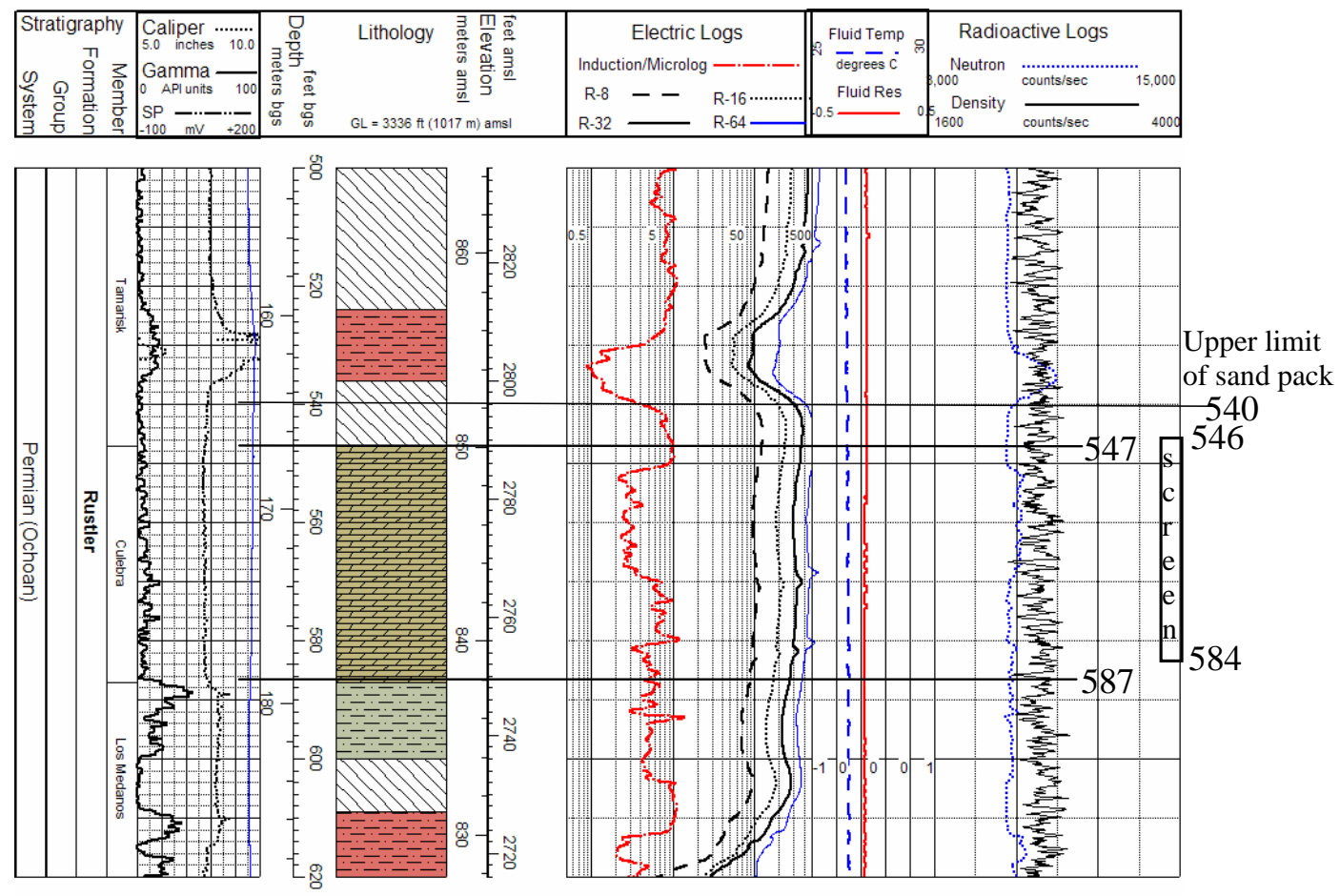




\title{
Dennis W. Powers, Ph. D. \\ Consulting Geologist
}

July 14,2003

\author{
Rey Carrasco \\ Geotechnical Engineering \\ Washington TRU Solutions \\ Carlsbad, NM 88220
}

Background

Storage and Retention of Cores and Rock Samples from SNL-12

Cores and cutting samples have been collected from drillhole SNL-12 in support of the drilling and testing program to investigate the hydrology of the Culebra Dolomite Member of the Rustler Formation as well as other units of hydrogeological significance to the program. These samples were collected under my supervision, and the chain-of-custody has been maintained by me and other WRES personnel. SNL12 is being drilled, completed, and tested under WTS contract provisions and under provisions in the hydrology program plan (SNL. 2003. Program Plan, WIPP Integrated Groundwater Hydrology Program, FY03-09, Revision 0. March 14, 2003. ERMS 526671).

\section{Core and Cuttings Storage Conditions}

There is no sample or core testing planned for SNL-12 requiring abnormal handling, preservation conditions, or immediate action to obtain test information. As a consequence, these samples and cores can be maintained in your current core storage facilities. Many of the cores obtained from SNL-12 are likely to be accessed in the next few months for further geologic studies to establish more details of stratigraphic, sedimentologic, and diagenetic conditions and events. These studies, if carried out, will be carried out under a formal plan, most likely developed under QA requirements of Sandia National Laboratories.

Core and Cuttings Retention Periods

It is recommended that cores obtained from SNL-12 be maintained indefinitely under normal storage conditions because of their relevance to hydrology and monitoring programs. The cores can be accessed for observations, and they can be removed for further laboratory study, including possible destruction, under a plan with appropriate management and QA approval.

It is recommended that cuttings samples be retained under normal storage conditions through the approval by EPA of the second CRA. The cuttings are commonly very fine in shallow sections and add little to the geologic record from initial observations as well as geophysical logs. Cuttings may be accessed for observation, and they may be removed for further laboratory study, including possible destruction, under a plan with appropriate management and QA approval.

\section{Supplemental Information}

Descriptive core logs and digital photographs of cores with a photograph log will be provided to you on CD-ROM format in accessible formats when the content has been approved for publication in the basic data report for SNL-12.

Dennis W. Powers

Copy to:

Ron Richardson, Environmental Monitoring, WRES

Richard L. Beauheim, Hydrology Lead, Sandia National Laboratories

140 Hemley Road, Anthony, TX 79821

Telephone: (915) 877-3929 E-mail: dwpowers@evaporites.com

FAX: (915) 877-5071 


\section{Appendix F Archeological Clearance Report}

The report from Mesa Field Services on the following three pages was converted from an original Word document to an Acrobat (pdf) file and reduced in size slightly to fit page formats. The original signed document is maintained by the land management coordinator, Environmental Monitoring and Hydrology Section (of WRES) for the WIPP Project. 
TITLE PAGE/ABSTRACT/

NEGATIVE SITE REPORT

BLM/CFO

CARLSBAD FIELD OFFICE

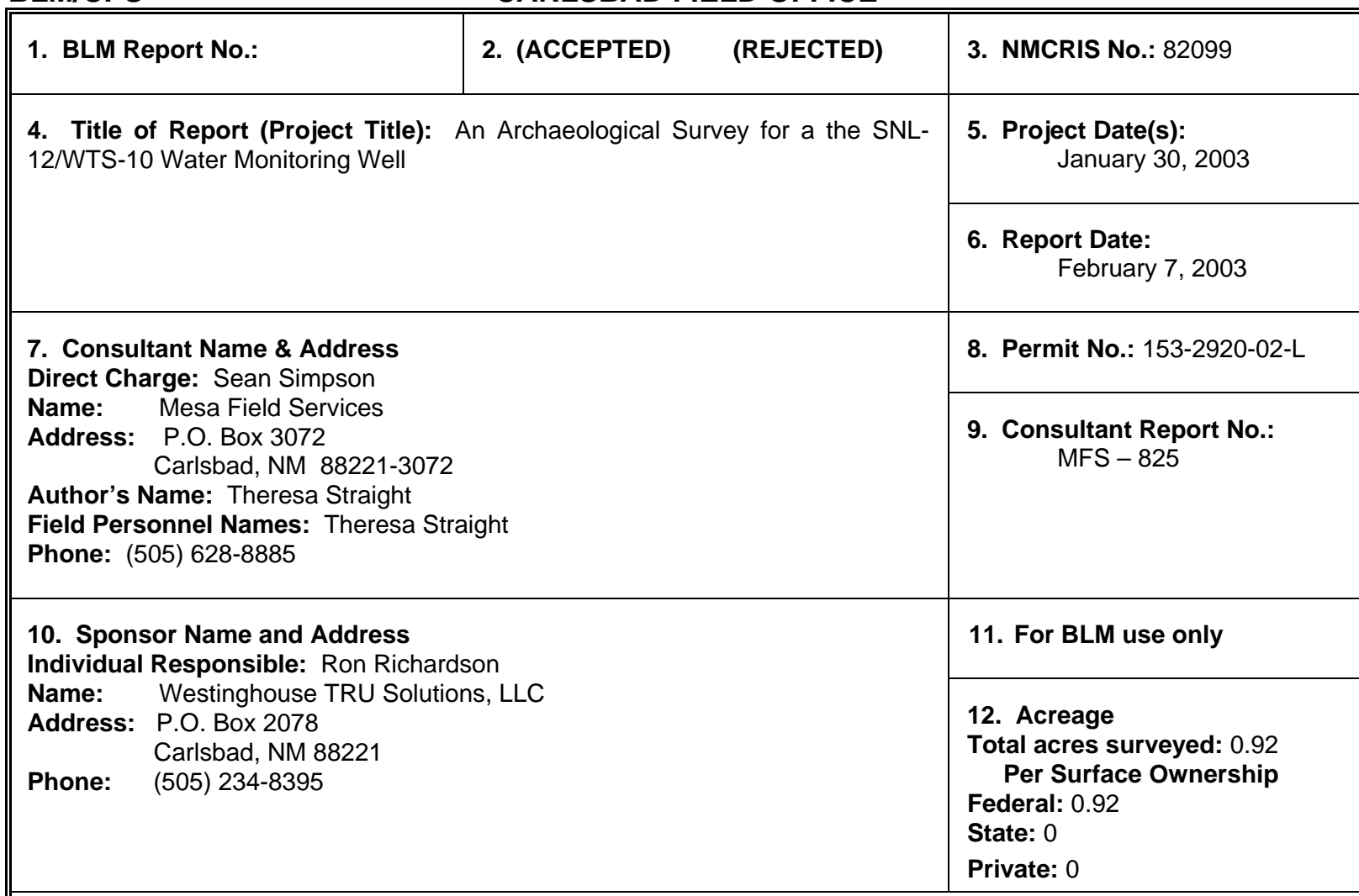

13. Location \& Area (maps attached if negative survey)

a. State: New Mexico

b. County: Eddy

c. BLM Field Office: Carlsbad

d. Nearest City or town: Carlsbad, NM

Location: T 23S, R 31E, Section 20: SW $1 / 4$ NW $1 / 4$ SE $1 / 4$

Well Pad Footages: N/A

f. 7.5' Map Name(s)and Code Number(s): Los Medanos, NM Provisional Edition 1985 (32103-C7)

g. Area

Block: Impact: $100 \mathrm{ft}$ by $100 \mathrm{ft}$

Surveyed: $200 \mathrm{ft}$ by $200 \mathrm{ft}$

Linear: Impact: N/A

Surveyed: N/A

14. a. Records Search

Location: Bureau of Land Management - Carlsbad Field Office and the Archaeological Records

Management System (ARMS) via modem

Date: January 29, 2003 by Natalie Allen

List by LA\# all sites within .25 miles of the project (those sites within 500 ' are to be shown on the project 
map): No previously recorded archaeological sites are within 0.25 miles of the project area.

b. Description of Undertaking (client's activities): Westinghouse TRU Solutions, LLC plans on drilling a water monitoring well. The pad for the well will be $100 \mathrm{ft}$ by $100 \mathrm{ft}$, yet an additional $50 \mathrm{ft}$ on each side, totaling a $200 \mathrm{ft}$ by $200 \mathrm{ft}$ area was surveyed to ensure the protection of cultural resources. The pad is located just off an existing well pad. The small corridor between the existing well pad and proposed pad was covered under the $50 \mathrm{ft}$ wide buffer surrounding the pad. This area will serve as access to the pad.

c. Environmental Setting (NRCS soil designation, vegetative community, etc.): The project is located on a plain with reddish brown sand of the Kermit-Berino soil association as defined by the Soil Conservation Service of the U.S. Department of Agriculture. Project elevations average 3,335 ft above mean sea level. Local vegetation is characteristic of Chihuahuan Desert Scrub and includes mesquite, yucca, bunch grasses, and noxious weeds. Due to this vegetative cover, ground surface visibility averaged 70 percent.

\section{d. Field Methods}

Transect Intervals: $15 \mathrm{~m}$

Crew Size: 1

Time in Field: 1 hour

Collections: None

15. Cultural Resource Findings: No cultural resources were observed within the project area. Identification and Description (location shown on project map):

16. Management Summary (recommendations): Because no cultural material was encountered archaeological clearance is recommended for the project area as staked. If any cultural material is encountered during construction activities, work at that location should stop and archaeologists at the BLM-CFO should be notified.

I certify that the information provided above is correct and accurate and meets all appreciable BLM standards.

Responsible Archaeologist:

Signature

Date

THE ABOVE COMPLETES A NEGATIVE REPORT. IF ELIGIBLE OR POTENTIALLY ELIGIBLE PROPERTIES ARE INVOLVED, THEN THE ABOVE WILL BE THE TITLE PAGE AND ABSTRACT FOR A COMPLETE REPORT. 


\section{Survey for the SN L-12/WT S-10 Water Monitoring Well}

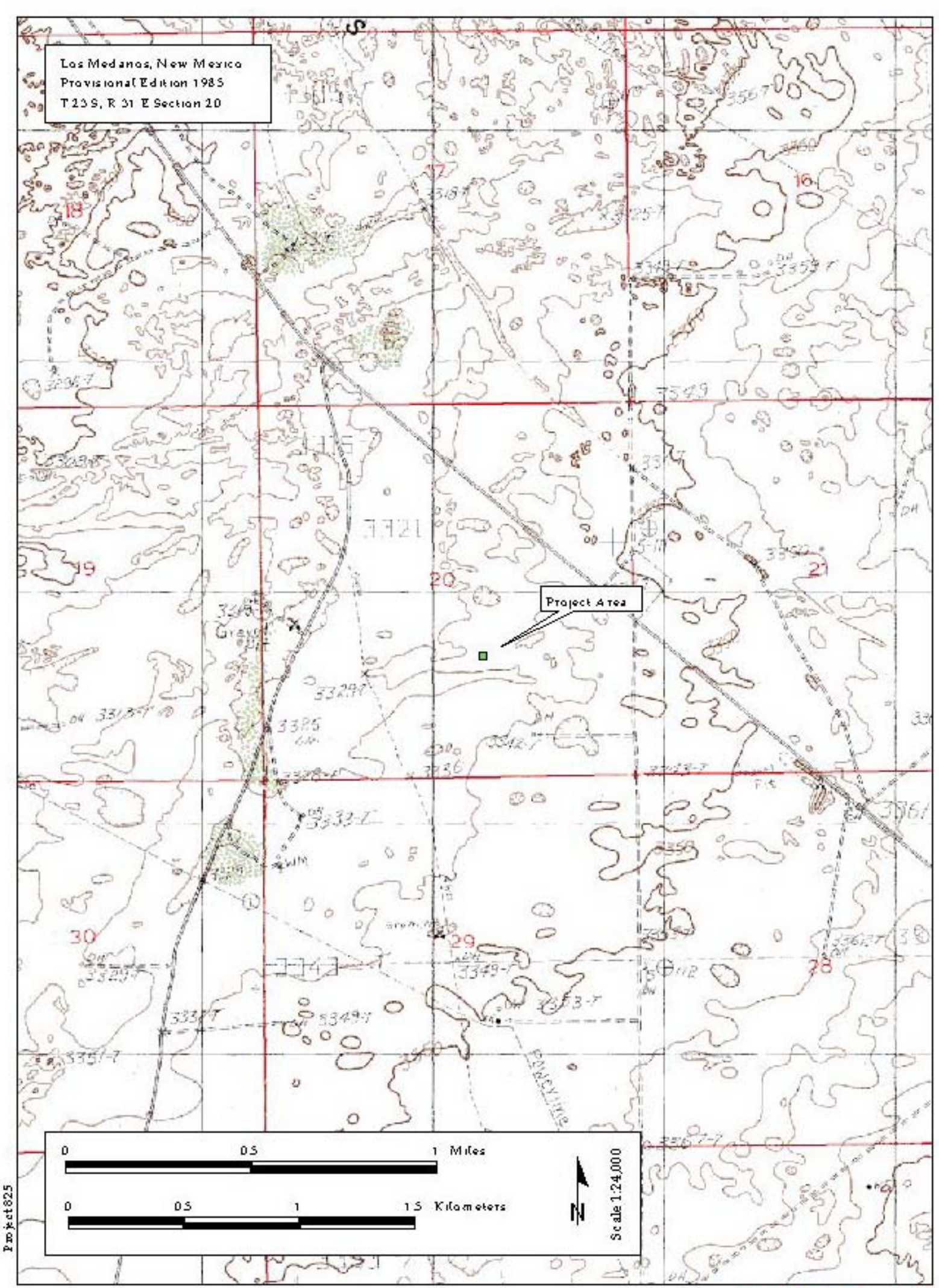

Figure 1. Project Area Map 


\section{Appendix G Photograph Logs}

Digital photographs were taken of the cores from SNL-12. These photographs have been compiled into a listing of consecutive photos beginning with the uppermost core (lower Forty-niner Member of the Rustler Formation) and ending with the lowermost (upper Salado Formation). Most of the photographs were taken in the field shortly after recovery. Cores are marked with depths and with arrows that point down, in the direction the drillhole is advancing. ACD-ROM with these images (jpeg format) is being archived, and a copy with photographic log is maintained by Geotechnical Engineering (of WTS) with records of the cores stored for WIPP. 


\begin{tabular}{|c|c|c|c|c|}
\hline \multicolumn{5}{|c|}{ Photograph Log Sheet } \\
\hline File & DATE & LOCATION & $\begin{array}{l}\text { DESCRIPTION OF SUBJECT } \\
\text { (includes individual/group names, } \\
\text { direction, etc. as appropriate) }\end{array}$ & $\begin{array}{l}\text { PHOTOGRAPHER } \\
\text { (initials and dept.) }\end{array}$ \\
\hline SNL-12_Core001.jpg & $7-08-03$ & $\begin{array}{l}\text { SNL-12 drillpad; } \\
\text { T23S, R31E; } \\
\text { sec20 }\end{array}$ & $\begin{array}{l}\text { Close-up photo of Forty-niner Mbr core, } \\
425.0-426.6 \mathrm{ft} \text { bgl, with markings, scale, } \\
\text { and time-date stamp }\end{array}$ & $\begin{array}{l}\text { DW Powers } \\
\text { Consultant to WTS }\end{array}$ \\
\hline SNL-12_Core002.jpg & 7-08-03 & $\begin{array}{l}\text { SNL-12 drillpad; } \\
\text { T23S, R31E, } \\
\text { sec20 }\end{array}$ & $\begin{array}{l}\text { Close-up photo of Forty-niner Mbr core, } \\
425.9 \text { - } 427.5 \mathrm{ft} \text { bgl, with markings, scale, } \\
\text { and time-date stamp }\end{array}$ & $\begin{array}{l}\text { DW Powers } \\
\text { Consultant to WTS }\end{array}$ \\
\hline SNL-12_Core003.jpg & 7-08-03 & $\begin{array}{l}\text { SNL-12 drillpad; } \\
\text { T23S, R31E, } \\
\text { sec20 }\end{array}$ & $\begin{array}{l}\text { Close-up photo of Forty-niner Mbr core, } \\
426.6 \text { - } 428.3 \mathrm{ft} \text { bgl, with markings, scale, } \\
\text { and time-date stamp }\end{array}$ & $\begin{array}{l}\text { DW Powers } \\
\text { Consultant to WTS }\end{array}$ \\
\hline SNL-12_Core004.jpg & 7-08-03 & $\begin{array}{l}\text { SNL-12 drillpad; } \\
\text { T23S, R31E, } \\
\text { sec20 }\end{array}$ & $\begin{array}{l}\text { Close-up photo of Forty-niner Mbr core, } \\
427.9 \text { - } 429.6 \mathrm{ft} \text { bgl, with markings, scale, } \\
\text { and time-date stamp }\end{array}$ & $\begin{array}{l}\text { DW Powers } \\
\text { Consultant to WTS }\end{array}$ \\
\hline SNL-12_Core005.jpg & $7-08-03$ & $\begin{array}{l}\text { SNL-12 drillpad; } \\
\text { T23S, R31E, } \\
\text { sec20 }\end{array}$ & $\begin{array}{l}\text { Close-up photo of Forty-niner Mbr core, } \\
429.2-430.9 \mathrm{ft} \text { bgl, with markings, scale, } \\
\text { and time-date stamp }\end{array}$ & $\begin{array}{l}\text { DW Powers } \\
\text { Consultant to WTS }\end{array}$ \\
\hline SNL-12_Core006.jpg & 7-08-03 & $\begin{array}{l}\text { SNL-12 drillpad; } \\
\text { T23S, R31E, } \\
\text { sec20 }\end{array}$ & $\begin{array}{l}\text { Close-up photo of Forty-niner Mbr core, } \\
429.8-431.4 \mathrm{ft} \text { bgl, with markings, scale, } \\
\text { and time-date stamp }\end{array}$ & $\begin{array}{l}\text { DW Powers } \\
\text { Consultant to WTS }\end{array}$ \\
\hline SNL-12_Core007.jpg & 7-08-03 & $\begin{array}{l}\text { SNL-12 drillpad; } \\
\text { T23S, R31E, } \\
\text { sec20 }\end{array}$ & $\begin{array}{l}\text { Close-up photo of Forty-niner Mbr core, } \\
430.5-432.2 \mathrm{ft} \text { bgl, with markings, scale, } \\
\text { and time-date stamp }\end{array}$ & $\begin{array}{l}\text { DW Powers } \\
\text { Consultant to WTS }\end{array}$ \\
\hline SNL-12_Core008.jpg & $7-08-03$ & $\begin{array}{l}\text { SNL-12 drillpad; } \\
\text { T23S, R31E, } \\
\text { sec20 }\end{array}$ & $\begin{array}{l}\text { Close-up photo of Forty-niner Mbr core, } \\
431.5 \text { - } 433.2 \mathrm{ft} \text { bgl, with markings, scale, } \\
\text { and time-date stamp }\end{array}$ & $\begin{array}{l}\text { DW Powers } \\
\text { Consultant to WTS }\end{array}$ \\
\hline SNL-12_Core009.jpg & 7-08-03 & $\begin{array}{l}\text { SNL-12 drillpad; } \\
\text { T23S, R31E, } \\
\text { sec20 }\end{array}$ & $\begin{array}{l}\text { Close-up photo of Forty-niner / Magenta } \\
\text { Dolomite Mbrs core, } 432.5 \text { - } 434.1 \mathrm{ft} \text { bgl, } \\
\text { with markings, scale, and time-date stamp }\end{array}$ & \begin{tabular}{|l} 
DW Powers \\
Consultant to WTS
\end{tabular} \\
\hline SNL-12_Core010.jpg & 7-08-03 & $\begin{array}{l}\text { SNL-12 drillpad; } \\
\text { T23S, R31E, } \\
\text { sec20 }\end{array}$ & $\begin{array}{l}\text { Close-up photo of Magenta Dolomite Mbr } \\
\text { core, } 433.5 \text { - } 435.1 \mathrm{ft} \text { bgl, with markings, } \\
\text { scale, and time-date stamp }\end{array}$ & \begin{tabular}{|l} 
DW Powers \\
Consultant to WTS
\end{tabular} \\
\hline SNL-12_Core011.jpg & $7-08-03$ & $\begin{array}{l}\text { SNL-12 drillpad; } \\
\text { T23S, R31E, } \\
\text { sec20 } \\
\end{array}$ & $\begin{array}{l}\text { Close-up photo of Magenta Dolomite Mbr } \\
\text { core, } 434.6 \text { - } 436.0 \mathrm{ft} \text { bgl, with markings, } \\
\text { scale, and time-date stamp }\end{array}$ & $\begin{array}{l}\text { DW Powers } \\
\text { Consultant to WTS }\end{array}$ \\
\hline SNL-12_Core012.jpg & 7-08-03 & $\begin{array}{l}\text { SNL-12 drillpad; } \\
\text { T23S, R31E, } \\
\text { sec20 }\end{array}$ & $\begin{array}{l}\text { Close-up photo of Magenta Dolomite Mbr } \\
\text { core, } 436.0 \text { - } 437.4 \mathrm{ft} \text { bgl, with markings, } \\
\text { scale, and time-date stamp }\end{array}$ & $\begin{array}{l}\text { DW Powers } \\
\text { Consultant to WTS }\end{array}$ \\
\hline SNL-12_Core013.jpg & 7-08-03 & $\begin{array}{l}\text { SNL-12 drillpad; } \\
\text { T23S, R31E, } \\
\text { sec20 }\end{array}$ & $\begin{array}{l}\text { Close-up photo of Magenta Dolomite Mbr } \\
\text { core, } 436.8 \text { - } 438.3 \mathrm{ft} \text { bgl, with markings, } \\
\text { scale, and time-date stamp }\end{array}$ & \begin{tabular}{|l} 
DW Powers \\
Consultant to WTS
\end{tabular} \\
\hline SNL-12_Core014.jpg & 7-08-03 & $\begin{array}{l}\text { SNL-12 drillpad; } \\
\text { T23S, R31E, } \\
\text { sec20 }\end{array}$ & $\begin{array}{l}\text { Close-up photo of Magenta Dolomite Mbr } \\
\text { core, } 437.8 \text { - } 439.4 \mathrm{ft} \text { bgl, with markings, } \\
\text { scale, and time-date stamp }\end{array}$ & $\begin{array}{l}\text { DW Powers } \\
\text { Consultant to WTS }\end{array}$ \\
\hline SNL-12_Core015.jpg & $7-08-03$ & $\begin{array}{l}\text { SNL-12 drillpad; } \\
\text { T23S, R31E, } \\
\text { sec20 } \\
\end{array}$ & $\begin{array}{l}\text { Close-up photo of Magenta Dolomite Mbr } \\
\text { core, } 438.8 \text { - } 440.3 \mathrm{ft} \text { bgl, with markings, } \\
\text { scale, and time-date stamp }\end{array}$ & $\begin{array}{l}\text { DW Powers } \\
\text { Consultant to WTS }\end{array}$ \\
\hline SNL-12_Core016.jpg & 7-08-03 & $\begin{array}{l}\text { SNL-12 drillpad; } \\
\text { T23S, R31E, } \\
\text { sec20 }\end{array}$ & $\begin{array}{l}\text { Close-up photo of Magenta Dolomite Mbr } \\
\text { core, } 439.8 \text { - } 441.3 \mathrm{ft} \text { bgl, with markings, } \\
\text { scale, and time-date stamp }\end{array}$ & $\begin{array}{l}\text { DW Powers } \\
\text { Consultant to WTS }\end{array}$ \\
\hline
\end{tabular}




\begin{tabular}{|c|c|c|c|c|}
\hline \multicolumn{5}{|c|}{ Photograph Log Sheet } \\
\hline File & DATE & LOCATION & $\begin{array}{l}\text { DESCRIPTION OF SUBJECT } \\
\text { (includes individual/group names, } \\
\text { direction, etc. as appropriate) }\end{array}$ & $\begin{array}{l}\text { PHOTOGRAPHER } \\
\text { (initials and dept.) }\end{array}$ \\
\hline SNL-12_Core017.jpg & $7-08-03$ & $\begin{array}{l}\text { SNL-12 drillpad; } \\
\text { T23S, R31E, } \\
\text { sec20 }\end{array}$ & $\begin{array}{l}\text { Close-up photo of Magenta Dolomite } \mathrm{Mbr} \\
\text { core, } 440.7 \text { - } 442.3 \mathrm{ft} \text { bgl, with markings, } \\
\text { scale, and time-date stamp }\end{array}$ & $\begin{array}{l}\text { DW Powers } \\
\text { Consultant to WTS }\end{array}$ \\
\hline SNL-12_Core018.jpg & $7-08-03$ & $\begin{array}{l}\text { SNL-12 drillpad; } \\
\text { T23S, R31E, } \\
\text { sec20 }\end{array}$ & $\begin{array}{l}\text { Close-up photo of Magenta Dolomite Mbr } \\
\text { core, } 441.6-443.2 \mathrm{ft} \text { bgl, with markings, } \\
\text { scale, and time-date stamp }\end{array}$ & \begin{tabular}{|l} 
DW Powers \\
Consultant to WTS
\end{tabular} \\
\hline SNL-12_Core019.jpg & $7-08-03$ & $\begin{array}{l}\text { SNL-12 drillpad; } \\
\text { T23S, R31E, } \\
\text { sec20 }\end{array}$ & $\begin{array}{l}\text { Close-up photo of Magenta Dolomite } \mathrm{Mbr} \\
\text { core, } 442.7 \text { - } 444.3 \mathrm{ft} \text { bgl, with markings, } \\
\text { scale, and time-date stamp }\end{array}$ & \begin{tabular}{|l} 
DW Powers \\
Consultant to WTS
\end{tabular} \\
\hline SNL-12_Core020.jpg & 7-08-03 & $\begin{array}{l}\text { SNL-12 drillpad; } \\
\text { T23S, R31E, } \\
\text { sec20 }\end{array}$ & $\begin{array}{l}\text { Close-up photo of Magenta Dolomite } \mathrm{Mbr} \\
\text { core, } 443.7 \text { - } 445.3 \mathrm{ft} \text { bgl, with markings, } \\
\text { scale, and time-date stamp }\end{array}$ & \begin{tabular}{|l} 
DW Powers \\
Consultant to WTS
\end{tabular} \\
\hline SNL-12_Core021.jpg & $7-08-03$ & $\begin{array}{l}\text { SNL-12 drillpad; } \\
\text { T23S, R31E, } \\
\text { sec20 }\end{array}$ & $\begin{array}{l}\text { Close-up photo of Magenta Dolomite Mbr } \\
\text { core, } 444.8-446.3 \mathrm{ft} \text { bgl, with markings, } \\
\text { scale, and time-date stamp }\end{array}$ & \begin{tabular}{|l} 
DW Powers \\
Consultant to WTS
\end{tabular} \\
\hline SNL-12_Core022.jpg & $7-08-03$ & $\begin{array}{l}\text { SNL-12 drillpad; } \\
\text { T23S, R31E, } \\
\text { sec20 }\end{array}$ & $\begin{array}{l}\text { Close-up photo of Magenta Dolomite Mbr } \\
\text { core, } 445.8 \text { - } 447.3 \mathrm{ft} \text { bgl, with markings, } \\
\text { scale, and time-date stamp }\end{array}$ & \begin{tabular}{|l} 
DW Powers \\
Consultant to WTS
\end{tabular} \\
\hline SNL-12_Core023.jpg & $7-08-03$ & $\begin{array}{l}\text { SNL-12 drillpad; } \\
\text { T23S, R31E, } \\
\text { sec20 }\end{array}$ & $\begin{array}{l}\text { Close-up photo of Magenta Dolomite Mbr } \\
\text { core, } 446.8 \text { - } 448.3 \mathrm{ft} \text { bgl, with markings, } \\
\text { scale, and time-date stamp }\end{array}$ & \begin{tabular}{|l} 
DW Powers \\
Consultant to WTS
\end{tabular} \\
\hline SNL-12_Core024.jpg & $7-08-03$ & $\begin{array}{l}\text { SNL-12 drillpad; } \\
\text { T23S, R31E, } \\
\text { sec20 }\end{array}$ & $\begin{array}{l}\text { Close-up photo of Magenta Dolomite Mbr } \\
\text { core, } 447.8 \text { - } 449.4 \mathrm{ft} \text { bgl, with markings, } \\
\text { scale, and time-date stamp }\end{array}$ & $\begin{array}{l}\text { DW Powers } \\
\text { Consultant to WTS }\end{array}$ \\
\hline SNL-12_Core025.jpg & $7-08-03$ & $\begin{array}{l}\text { SNL-12 drillpad; } \\
\text { T23S, R31E, } \\
\text { sec20 }\end{array}$ & $\begin{array}{l}\text { Close-up photo of Magenta Dolomite Mbr } \\
\text { core, } 448.8 \text { - } 450.3 \mathrm{ft} \text { bgl, with markings, } \\
\text { scale, and time-date stamp }\end{array}$ & \begin{tabular}{|l} 
DW Powers \\
Consultant to WTS
\end{tabular} \\
\hline SNL-12_Core026.jpg & $7-08-03$ & $\begin{array}{l}\text { SNL-12 drillpad; } \\
\text { T23S, R31E, } \\
\text { sec20 }\end{array}$ & $\begin{array}{l}\text { Close-up photo of Magenta Dolomite Mbr } \\
\text { core, } 449.8 \text { - } 451.3 \mathrm{ft} \text { bgl, with markings, } \\
\text { scale, and time-date stamp }\end{array}$ & $\begin{array}{l}\text { DW Powers } \\
\text { Consultant to WTS }\end{array}$ \\
\hline SNL-12_Core027.jpg & $7-08-03$ & $\begin{array}{l}\text { SNL-12 drillpad; } \\
\text { T23S, R31E, } \\
\text { sec20 }\end{array}$ & $\begin{array}{l}\text { Close-up photo of Magenta Dolomite Mbr } \\
\text { core, } 450.8 \text { - } 452.3 \mathrm{ft} \text { bgl, with markings, } \\
\text { scale, and time-date stamp }\end{array}$ & \begin{tabular}{|l} 
DW Powers \\
Consultant to WTS
\end{tabular} \\
\hline SNL-12_Core028.jpg & $7-08-03$ & $\begin{array}{l}\text { SNL-12 drillpad; } \\
\text { T23S, R31E, } \\
\text { sec20 }\end{array}$ & $\begin{array}{l}\text { Close-up photo of Magenta Dolomite Mbr } \\
\text { core, } 451.8 \text { - } 453.3 \mathrm{ft} \text { bgl, with markings, } \\
\text { scale, and time-date stamp }\end{array}$ & $\begin{array}{l}\text { DW Powers } \\
\text { Consultant to WTS }\end{array}$ \\
\hline SNL-12_Core029.jpg & 7-08-03 & $\begin{array}{l}\text { SNL-12 drillpad; } \\
\text { T23S, R31E, } \\
\text { sec20 }\end{array}$ & $\begin{array}{l}\text { Close-up photo of Magenta Dolomite Mbr } \\
\text { core, } 452.7 \text { - } 454.1 \mathrm{ft} \text { bgl, with markings, } \\
\text { scale, and time-date stamp }\end{array}$ & \begin{tabular}{|l|} 
DW Powers \\
Consultant to WTS
\end{tabular} \\
\hline SNL-12_Core030.jpg & $7-08-03$ & $\begin{array}{l}\text { SNL-12 drillpad; } \\
\text { T23S, R31E, } \\
\text { sec20 }\end{array}$ & $\begin{array}{l}\text { Close-up photo of Magenta Dolomite } \mathrm{Mbr} \\
\text { core, } 454.0 \text { - } 455.3 \mathrm{ft} \text { bgl, with markings, } \\
\text { scale, and time-date stamp }\end{array}$ & \begin{tabular}{|l|} 
DW Powers \\
Consultant to WTS
\end{tabular} \\
\hline SNL-12_Core031.jpg & $7-08-03$ & $\begin{array}{l}\text { SNL-12 drillpad; } \\
\text { T23S, R31E, } \\
\text { sec20 }\end{array}$ & $\begin{array}{l}\text { Close-up photo of Magenta Dolomite Mbr } \\
\text { core, } 454.7 \text { - } 456.1 \mathrm{ft} \text { bgl, with markings, } \\
\text { scale, and time-date stamp }\end{array}$ & $\begin{array}{l}\text { DW Powers } \\
\text { Consultant to WTS }\end{array}$ \\
\hline SNL-12_Core032.jpg & $7-08-03$ & $\begin{array}{l}\text { SNL-12 drillpad; } \\
\text { T23S, R31E, } \\
\text { sec20 }\end{array}$ & $\begin{array}{l}\text { Close-up photo of Magenta Dolomite } \mathrm{Mbr} \\
\text { core, } 455.7 \text { - } 457.0 \mathrm{ft} \text { bgl, with markings, } \\
\text { scale, and time-date stamp }\end{array}$ & $\begin{array}{l}\text { DW Powers } \\
\text { Consultant to WTS }\end{array}$ \\
\hline
\end{tabular}




\begin{tabular}{|c|c|c|c|c|}
\hline \multicolumn{5}{|c|}{ Photograph Log Sheet } \\
\hline File & DATE & LOCATION & $\begin{array}{c}\text { DESCRIPTION OF SUBJECT } \\
\text { (includes individual/group names, } \\
\text { direction, etc. as appropriate) }\end{array}$ & $\begin{array}{l}\text { PHOTOGRAPHER } \\
\text { (initials and dept.) }\end{array}$ \\
\hline SNL-12_Core033.jpg & $7-08-03$ & $\begin{array}{l}\text { SNL-12 drillpad; } \\
\text { T23S, R31E, } \\
\text { sec20 }\end{array}$ & $\begin{array}{l}\text { Close-up photo of Magenta Dolomite Mbr } \\
\text { core, } 456.8 \text { - } 458.2 \mathrm{ft} \text { bgl, with markings, } \\
\text { scale, and time-date stamp }\end{array}$ & \begin{tabular}{|l} 
DW Powers \\
Consultant to WTS
\end{tabular} \\
\hline SNL-12_Core034.jpg & $7-08-03$ & $\begin{array}{l}\text { SNL-12 drillpad; } \\
\text { T23S, R31E, } \\
\text { sec20 }\end{array}$ & $\begin{array}{l}\text { Close-up photo of Magenta Dolomite } \mathrm{Mbr} \\
\text { core, } 457.8 \text { - } 459.1 \mathrm{ft} \text { bgl, with markings, } \\
\text { scale, and time-date stamp }\end{array}$ & \begin{tabular}{|l} 
DW Powers \\
Consultant to WTS
\end{tabular} \\
\hline SNL-12_Core035.jpg & $7-08-03$ & $\begin{array}{l}\text { SNL-12 drillpad; } \\
\text { T23S, R31E, } \\
\text { sec20 }\end{array}$ & $\begin{array}{l}\text { Close-up photo of Magenta Dolomite Mbr } \\
\text { core, } 458.8 \text { - } 460.2 \mathrm{ft} \text { bgl, with markings, } \\
\text { scale, and time-date stamp }\end{array}$ & $\begin{array}{l}\text { DW Powers } \\
\text { Consultant to WTS }\end{array}$ \\
\hline SNL-12_Core036.jpg & 7-08-03 & $\begin{array}{l}\text { SNL-12 drillpad; } \\
\text { T23S, R31E, } \\
\text { sec20 }\end{array}$ & $\begin{array}{l}\text { Close-up photo of Magenta Dolomite / } \\
\text { Tamarisk Mbrs core, } 459.7-461.2 \mathrm{ft} \text { bgl, } \\
\text { with markings, scale, and time-date stamp }\end{array}$ & \begin{tabular}{|l|} 
DW Powers \\
Consultant to WTS
\end{tabular} \\
\hline SNL-12_Core037.jpg & $7-08-03$ & $\begin{array}{l}\text { SNL-12 drillpad; } \\
\text { T23S, R31E, } \\
\text { sec20 }\end{array}$ & $\begin{array}{l}\text { Close-up photo of Tamarisk (A3) Mbr } \\
\text { core, } 460.9-462.2 \mathrm{ft} \text { bgl, with markings, } \\
\text { scale, and time-date stamp }\end{array}$ & \begin{tabular}{|l} 
DW Powers \\
Consultant to WTS
\end{tabular} \\
\hline SNL-12_Core038.jpg & $7-08-03$ & $\begin{array}{l}\text { SNL-12 drillpad; } \\
\text { T23S, R31E, } \\
\text { sec20 }\end{array}$ & $\begin{array}{l}\text { Close-up photo of Tamarisk (A3) Mbr } \\
\text { core, } 461.8 \text { - } 463.1 \mathrm{ft} \text { bgl, with markings, } \\
\text { scale, and time-date stamp }\end{array}$ & \begin{tabular}{|l} 
DW Powers \\
Consultant to WTS
\end{tabular} \\
\hline SNL-12_Core039.jpg & $7-08-03$ & $\begin{array}{l}\text { SNL-12 drillpad; } \\
\text { T23S, R31E, } \\
\text { sec20 }\end{array}$ & $\begin{array}{l}\text { Close-up photo of Tamarisk (A3) Mbr } \\
\text { core, } 462.8 \text { - } 464.2 \mathrm{ft} \text { bgl, with markings, } \\
\text { scale, and time-date stamp }\end{array}$ & \begin{tabular}{|l} 
DW Powers \\
Consultant to WTS
\end{tabular} \\
\hline SNL-12_Core040.jpg & $7-08-03$ & $\begin{array}{l}\text { SNL-12 drillpad; } \\
\text { T23S, R31E, } \\
\text { sec20 }\end{array}$ & $\begin{array}{l}\text { Close-up photo of Tamarisk (A3) Mbr } \\
\text { core, } 463.8-465.1 \mathrm{ft} \text { bgl, with markings, } \\
\text { scale, and time-date stamp }\end{array}$ & \begin{tabular}{|l|} 
DW Powers \\
Consultant to WTS
\end{tabular} \\
\hline SNL-12_Core041.jpg & $7-08-03$ & $\begin{array}{l}\text { SNL-12 drillpad; } \\
\text { T23S, R31E, } \\
\text { sec20 }\end{array}$ & $\begin{array}{l}\text { Close-up photo of Tamarisk (A3) Mbr } \\
\text { core, } 464.9-466.2 \mathrm{ft} \text { bgl, with markings, } \\
\text { scale, and time-date stamp }\end{array}$ & \begin{tabular}{|l} 
DW Powers \\
Consultant to WTS
\end{tabular} \\
\hline SNL-12_Core042.jpg & $7-08-03$ & $\begin{array}{l}\text { SNL-12 drillpad; } \\
\text { T23S, R31E, } \\
\text { sec20 }\end{array}$ & $\begin{array}{l}\text { Close-up photo of Tamarisk (A3) Mbr } \\
\text { core, } 465.8 \text { - } 467.2 \mathrm{ft} \text { bgl, with markings, } \\
\text { scale, and time-date stamp }\end{array}$ & \begin{tabular}{|l|} 
DW Powers \\
Consultant to WTS
\end{tabular} \\
\hline SNL-12_Core043.jpg & $7-08-03$ & $\begin{array}{l}\text { SNL-12 drillpad; } \\
\text { T23S, R31E, } \\
\text { sec20 }\end{array}$ & $\begin{array}{l}\text { Close-up photo of Tamarisk (A3) Mbr } \\
\text { core, } 466.8 \text { - } 468.2 \mathrm{ft} \text { bgl, with markings, } \\
\text { scale, and time-date stamp }\end{array}$ & \begin{tabular}{|l} 
DW Powers \\
Consultant to WTS
\end{tabular} \\
\hline SNL-12_Core044.jpg & 7-08-03 & $\begin{array}{l}\text { SNL-12 drillpad; } \\
\text { T23S, R31E, } \\
\text { sec20 }\end{array}$ & $\begin{array}{l}\text { Close-up photo of Tamarisk (A3) Mbr } \\
\text { core, } 467.8-469.2 \mathrm{ft} \text { bgl, with markings, } \\
\text { scale, and time-date stamp }\end{array}$ & \begin{tabular}{|l|} 
DW Powers \\
Consultant to WTS
\end{tabular} \\
\hline SNL-12_Core045.jpg & 7-08-03 & $\begin{array}{l}\text { SNL-12 drillpad; } \\
\text { T23S, R31E, } \\
\text { sec20 }\end{array}$ & $\begin{array}{l}\text { Close-up photo of Tamarisk (A3) Mbr } \\
\text { core, } 468.8-470.1 \mathrm{ft} \text { bgl, with markings, } \\
\text { scale, and time-date stamp }\end{array}$ & \begin{tabular}{|l|} 
DW Powers \\
Consultant to WTS
\end{tabular} \\
\hline SNL-12_Core046.jpg & $7-08-03$ & $\begin{array}{l}\text { SNL-12 drillpad; } \\
\text { T23S, R31E, } \\
\text { sec20 }\end{array}$ & $\begin{array}{l}\text { Close-up photo of Tamarisk (A3) Mbr } \\
\text { core, } 469.4 \text { - } 470.5 \mathrm{ft} \text { bgl, with markings, } \\
\text { scale, and time-date stamp }\end{array}$ & \begin{tabular}{|l|} 
DW Powers \\
Consultant to WTS
\end{tabular} \\
\hline SNL-12_Core047.jpg & $7-09-03$ & $\begin{array}{l}\text { SNL-12 drillpad; } \\
\text { T23S, R31E, } \\
\text { sec20 }\end{array}$ & $\begin{array}{l}\text { Close-up photo of Tamarisk (A3) Mbr } \\
\text { core, } 520.0-521.1 \mathrm{ft} \text { bgl, with markings, } \\
\text { scale, and time-date stamp }\end{array}$ & \begin{tabular}{|l} 
DW Powers \\
Consultant to WTS
\end{tabular} \\
\hline SNL-12_Core048.jpg & $7-09-03$ & $\begin{array}{l}\text { SNL-12 drillpad; } \\
\text { T23S, R31E, } \\
\text { sec20 }\end{array}$ & $\begin{array}{l}\text { Close-up photo of Tamarisk (A3) Mbr } \\
\text { core, } 520.8 \text { - } 522.1 \mathrm{ft} \text { bgl, with markings, } \\
\text { scale, and time-date stamp }\end{array}$ & \begin{tabular}{|l|} 
DW Powers \\
Consultant to WTS
\end{tabular} \\
\hline
\end{tabular}




\begin{tabular}{|c|c|c|c|c|}
\hline \multicolumn{5}{|c|}{ Photograph Log Sheet } \\
\hline File & DATE & LOCATION & $\begin{array}{l}\text { DESCRIPTION OF SUBJECT } \\
\text { (includes individual/group names, } \\
\text { direction, etc. as appropriate) }\end{array}$ & $\begin{array}{l}\text { PHOTOGRAPHER } \\
\text { (initials and dept.) }\end{array}$ \\
\hline SNL-12_Core049.jpg & 7-09-03 & $\begin{array}{l}\text { SNL-12 drillpad; } \\
\text { T23S, R31E, } \\
\text { sec20 }\end{array}$ & $\begin{array}{l}\text { Close-up photo of Tamarisk (A3) Mbr } \\
\text { core, } 521.8-523.2 \mathrm{ft} \text { bgl, with markings, } \\
\text { scale, and time-date stamp }\end{array}$ & $\begin{array}{l}\text { DW Powers } \\
\text { Consultant to WTS }\end{array}$ \\
\hline SNL-12_Core050.jpg & $7-09-03$ & $\begin{array}{l}\text { SNL-12 drillpad; } \\
\text { T23S, R31E, } \\
\text { sec20 }\end{array}$ & $\begin{array}{l}\text { Close-up photo of Tamarisk (A3) Mbr } \\
\text { core, } 522.9-524.2 \mathrm{ft} \text { bgl, with markings, } \\
\text { scale, and time-date stamp }\end{array}$ & $\begin{array}{l}\text { DW Powers } \\
\text { Consultant to WTS }\end{array}$ \\
\hline SNL-12_Core051.jpg & $7-09-03$ & $\begin{array}{l}\text { SNL-12 drillpad; } \\
\text { T23S, R31E, } \\
\text { sec20 }\end{array}$ & $\begin{array}{l}\text { Close-up photo of Tamarisk (A3) Mbr } \\
\text { core, } 523.8 \text { - } 525.2 \mathrm{ft} \text { bgl, with markings, } \\
\text { scale, and time-date stamp }\end{array}$ & $\begin{array}{l}\text { DW Powers } \\
\text { Consultant to WTS }\end{array}$ \\
\hline SNL-12_Core052.jpg & 7-09-03 & $\begin{array}{l}\text { SNL-12 drillpad; } \\
\text { T23S, R31E, } \\
\text { sec20 }\end{array}$ & $\begin{array}{l}\text { Close-up photo of Tamarisk (A3 to M3/H3) } \\
\text { Mbr core, } 524.8 \text { - } 526.1 \mathrm{ft} \text { bgl, with } \\
\text { markings, scale, and time-date stamp }\end{array}$ & $\begin{array}{l}\text { DW Powers } \\
\text { Consultant to WTS }\end{array}$ \\
\hline SNL-12_Core053.jpg & 7-09-03 & $\begin{array}{l}\text { SNL-12 drillpad; } \\
\text { T23S, R31E, } \\
\text { sec20 }\end{array}$ & $\begin{array}{l}\text { Close-up photo of Tamarisk (M3/H3) Mbr } \\
\text { core, } 525.8-527.1 \mathrm{ft} \text { bgl, with markings, } \\
\text { scale, and time-date stamp }\end{array}$ & \begin{tabular}{|l} 
DW Powers \\
Consultant to WTS
\end{tabular} \\
\hline SNL-12_Core054.jpg & $7-09-03$ & $\begin{array}{l}\text { SNL-12 drillpad; } \\
\text { T23S, R31E, } \\
\text { sec20 }\end{array}$ & $\begin{array}{l}\text { Close-up photo of Tamarisk }(\mathrm{M} 3 / \mathrm{H} 3) \mathrm{Mbr} \\
\text { core, } 526.8-528.2 \mathrm{ft} \text { bgl, with markings, } \\
\text { scale, and time-date stamp }\end{array}$ & \begin{tabular}{|l} 
DW Powers \\
Consultant to WTS
\end{tabular} \\
\hline SNL-12_Core055.jpg & $7-09-03$ & $\begin{array}{l}\text { SNL-12 drillpad; } \\
\text { T23S, R31E, } \\
\text { sec20 }\end{array}$ & $\begin{array}{l}\text { Close-up photo of Tamarisk }(\mathrm{M} 3 / \mathrm{H} 3) \mathrm{Mbr} \\
\text { core, } 527.7 \text { - } 529.1 \mathrm{ft} \text { bgl, with markings, } \\
\text { scale, and time-date stamp }\end{array}$ & \begin{tabular}{|l} 
DW Powers \\
Consultant to WTS
\end{tabular} \\
\hline SNL-12_Core056.jpg & 7-09-03 & $\begin{array}{l}\text { SNL-12 drillpad; } \\
\text { T23S, R31E, } \\
\text { sec20 }\end{array}$ & $\begin{array}{l}\text { Close-up photo of Tamarisk (M3/H3) Mbr } \\
\text { core, } 528.8 \text { - } 530.1 \mathrm{ft} \text { bgl, with markings, } \\
\text { scale, and time-date stamp }\end{array}$ & $\begin{array}{l}\text { DW Powers } \\
\text { Consultant to WTS }\end{array}$ \\
\hline SNL-12_Core057.jpg & 7-09-03 & $\begin{array}{l}\text { SNL-12 drillpad; } \\
\text { T23S, R31E, } \\
\text { sec20 }\end{array}$ & $\begin{array}{l}\text { Close-up photo of Tamarisk (M3/H3) Mbr } \\
\text { core, } 529.6 \text { - } 530.4 \mathrm{ft} \text { bgl, with markings, } \\
\text { scale, and time-date stamp }\end{array}$ & \begin{tabular}{|l} 
DW Powers \\
Consultant to WTS
\end{tabular} \\
\hline SNL-12_Core058.jpg & 7-09-03 & $\begin{array}{l}\text { SNL-12 drillpad; } \\
\text { T23S, R31E, } \\
\text { sec20 }\end{array}$ & $\begin{array}{l}\text { Close-up photo of Tamarisk (M3/H3) Mbr } \\
\text { core, } 530.3-531.4 \mathrm{ft} \text { bgl, with markings, } \\
\text { scale, and time-date stamp }\end{array}$ & $\begin{array}{l}\text { DW Powers } \\
\text { Consultant to WTS }\end{array}$ \\
\hline SNL-12_Core059.jpg & 7-09-03 & $\begin{array}{l}\text { SNL-12 drillpad; } \\
\text { T23S, R31E, } \\
\text { sec20 }\end{array}$ & $\begin{array}{l}\text { Close-up photo of Tamarisk (M3/H3) Mbr } \\
\text { core, } 530.8 \text { - } 532.1 \mathrm{ft} \text { bgl, with markings, } \\
\text { scale, and time-date stamp }\end{array}$ & $\begin{array}{l}\text { DW Powers } \\
\text { Consultant to WTS }\end{array}$ \\
\hline SNL-12_Core060.jpg & 7-09-03 & $\begin{array}{l}\text { SNL-12 drillpad; } \\
\text { T23S, R31E, } \\
\text { sec20 }\end{array}$ & $\begin{array}{l}\text { Close-up photo of Tamarisk }(\mathrm{M} 3 / \mathrm{H} 3) \mathrm{Mbr} \\
\text { core, } 531.8 \text { - } 533.1 \mathrm{ft} \text { bgl, with markings, } \\
\text { scale, and time-date stamp }\end{array}$ & $\begin{array}{l}\text { DW Powers } \\
\text { Consultant to WTS }\end{array}$ \\
\hline SNL-12_Core061.jpg & $7-09-03$ & $\begin{array}{l}\text { SNL-12 drillpad; } \\
\text { T23S, R31E, } \\
\text { sec20 }\end{array}$ & $\begin{array}{l}\text { Close-up photo of Tamarisk (M3/H3) Mbr } \\
\text { core, } 532.7 \text { - } 534.1 \mathrm{ft} \text { bgl, with markings, } \\
\text { scale, and time-date stamp }\end{array}$ & \begin{tabular}{|l|} 
DW Powers \\
Consultant to WTS
\end{tabular} \\
\hline SNL-12_Core062.jpg & 7-09-03 & $\begin{array}{l}\text { SNL-12 drillpad; } \\
\text { T23S, R31E, } \\
\text { sec20 }\end{array}$ & $\begin{array}{l}\text { Close-up photo of Tamarisk }(\mathrm{M} 3 / \mathrm{H} 3) \mathrm{Mbr} \\
\text { core, } 533.8 \text { - } 535.2 \mathrm{ft} \text { bgl, with markings, } \\
\text { scale, and time-date stamp }\end{array}$ & \begin{tabular}{|l} 
DW Powers \\
Consultant to WTS
\end{tabular} \\
\hline SNL-12_Core063.jpg & $7-09-03$ & $\begin{array}{l}\text { SNL-12 drillpad; } \\
\text { T23S, R31E, } \\
\text { sec20 }\end{array}$ & $\begin{array}{l}\text { Close-up photo of Tamarisk }(\mathrm{M} 3 / \mathrm{H} 3) \mathrm{Mbr} \\
\text { core, } 534.8 \text { - } 536.2 \mathrm{ft} \text { bgl, with markings, } \\
\text { scale, and time-date stamp }\end{array}$ & $\begin{array}{l}\text { DW Powers } \\
\text { Consultant to WTS }\end{array}$ \\
\hline SNL-12_Core064.jpg & 7-09-03 & $\begin{array}{l}\text { SNL-12 drillpad; } \\
\text { T23S, R31E, } \\
\text { sec20 }\end{array}$ & $\begin{array}{l}\text { Close-up photo of Tamarisk (M3/H3) Mbr } \\
\text { core, } 534.9 \text { - } 536.4 \mathrm{ft} \text { bgl, with markings, } \\
\text { scale, and time-date stamp }\end{array}$ & $\begin{array}{l}\text { DW Powers } \\
\text { Consultant to WTS }\end{array}$ \\
\hline
\end{tabular}




\begin{tabular}{|c|c|c|c|c|}
\hline \multicolumn{5}{|c|}{ Photograph Log Sheet } \\
\hline File & DATE & LOCATION & $\begin{array}{l}\text { DESCRIPTION OF SUBJECT } \\
\text { (includes individual/group names, } \\
\text { direction, etc. as appropriate) }\end{array}$ & $\begin{array}{l}\text { PHOTOGRAPHER } \\
\text { (initials and dept.) }\end{array}$ \\
\hline SNL-12_Core065.jpg & 7-09-03 & $\begin{array}{l}\text { SNL-12 drillpad; } \\
\text { T23S, R31E, } \\
\text { sec20 }\end{array}$ & \begin{tabular}{|l|} 
Close-up photo of Tamarisk (M3/H3 to A2) \\
Mbr core, $535.8-537.1 \mathrm{ft}$ bgl, with \\
markings, scale, and time-date stamp
\end{tabular} & $\begin{array}{l}\text { DW Powers } \\
\text { Consultant to WTS }\end{array}$ \\
\hline SNL-12_Core066.jpg & 7-09-03 & $\begin{array}{l}\text { SNL-12 drillpad; } \\
\text { T23S, R31E, } \\
\text { sec20 }\end{array}$ & $\begin{array}{l}\text { Close-up photo of Tamarisk (A2) Mbr } \\
\text { core, } 536.7 \text { - } 538.1 \mathrm{ft} \text { bgl, with markings, } \\
\text { scale, and time-date stamp }\end{array}$ & \begin{tabular}{|l} 
DW Powers \\
Consultant to WTS
\end{tabular} \\
\hline SNL-12_Core067.jpg & 7-09-03 & $\begin{array}{l}\text { SNL-12 drillpad; } \\
\text { T23S, R31E, } \\
\text { sec20 } \\
\end{array}$ & $\begin{array}{l}\text { Close-up photo of Tamarisk (A2) Mbr } \\
\text { core, } 537.7 \text { - } 539.1 \mathrm{ft} \text { bgl, with markings, } \\
\text { scale, and time-date stamp }\end{array}$ & $\begin{array}{l}\text { DW Powers } \\
\text { Consultant to WTS }\end{array}$ \\
\hline SNL-12_Core068.jpg & 7-09-03 & $\begin{array}{l}\text { SNL-12 drillpad; } \\
\text { T23S, R31E, } \\
\text { sec20 }\end{array}$ & $\begin{array}{l}\text { Close-up photo of Tamarisk (A2) Mbr } \\
\text { core, } 538.8-540.2 \mathrm{ft} \text { bgl, with markings, } \\
\text { scale, and time-date stamp }\end{array}$ & $\begin{array}{l}\text { DW Powers } \\
\text { Consultant to WTS }\end{array}$ \\
\hline SNL-12_Core069.jpg & 7-09-03 & $\begin{array}{l}\text { SNL-12 drillpad; } \\
\text { T23S, R31E, } \\
\text { sec20 }\end{array}$ & $\begin{array}{l}\text { Close-up photo of Tamarisk (A2) Mbr } \\
\text { core, } 539.8-541.1 \mathrm{ft} \text { bgl, with markings, } \\
\text { scale, and time-date stamp }\end{array}$ & $\begin{array}{l}\text { DW Powers } \\
\text { Consultant to WTS }\end{array}$ \\
\hline SNL-12_Core070.jpg & 7-09-03 & $\begin{array}{l}\text { SNL-12 drillpad; } \\
\text { T23S, R31E, } \\
\text { sec20 }\end{array}$ & $\begin{array}{l}\text { Close-up photo of Tamarisk (A2) Mbr } \\
\text { core, } 540.8-542.1 \mathrm{ft} \text { bgl, with markings, } \\
\text { scale, and time-date stamp }\end{array}$ & \begin{tabular}{|l} 
DW Powers \\
Consultant to WTS
\end{tabular} \\
\hline SNL-12_Core071.jpg & 7-09-03 & $\begin{array}{l}\text { SNL-12 drillpad; } \\
\text { T23S, R31E, } \\
\text { sec20 }\end{array}$ & $\begin{array}{l}\text { Close-up photo of Tamarisk (A2) Mbr } \\
\text { core, } 541.8-543.2 \mathrm{ft} \text { bgl, with markings, } \\
\text { scale, and time-date stamp }\end{array}$ & $\begin{array}{l}\text { DW Powers } \\
\text { Consultant to WTS }\end{array}$ \\
\hline SNL-12_Core072.jpg & 7-09-03 & $\begin{array}{l}\text { SNL-12 drillpad; } \\
\text { T23S, R31E, } \\
\text { sec20 }\end{array}$ & $\begin{array}{l}\text { Close-up photo of Tamarisk (A2) Mbr } \\
\text { core, } 542.8 \text { - } 544.2 \mathrm{ft} \text { bgl, with markings, } \\
\text { scale, and time-date stamp }\end{array}$ & $\begin{array}{l}\text { DW Powers } \\
\text { Consultant to WTS }\end{array}$ \\
\hline SNL-12_Core073.jpg & 7-09-03 & $\begin{array}{l}\text { SNL-12 drillpad; } \\
\text { T23S, R31E, } \\
\text { sec20 }\end{array}$ & $\begin{array}{l}\text { Close-up photo of Tamarisk (A2) Mbr } \\
\text { core, } 543.7-545.1 \mathrm{ft} \text { bgl, with markings, } \\
\text { scale, and time-date stamp }\end{array}$ & $\begin{array}{l}\text { DW Powers } \\
\text { Consultant to WTS }\end{array}$ \\
\hline SNL-12_Core074.jpg & 7-09-03 & $\begin{array}{l}\text { SNL-12 drillpad; } \\
\text { T23S, R31E, } \\
\text { sec20 }\end{array}$ & $\begin{array}{l}\text { Close-up photo of Tamarisk (A2) Mbr } \\
\text { core, } 544.8-546.1 \mathrm{ft} \text { bgl, with markings, } \\
\text { scale, and time-date stamp }\end{array}$ & \begin{tabular}{|l} 
DW Powers \\
Consultant to WTS
\end{tabular} \\
\hline SNL-12_Core075.jpg & 7-09-03 & $\begin{array}{l}\text { SNL-12 drillpad; } \\
\text { T23S, R31E, } \\
\text { sec20 }\end{array}$ & $\begin{array}{l}\text { Close-up photo of Tamarisk (A2) Mbr } \\
\text { core, } 545.8-547.2 \mathrm{ft} \text { bgl, with markings, } \\
\text { scale, and time-date stamp }\end{array}$ & \begin{tabular}{|l} 
DW Powers \\
Consultant to WTS
\end{tabular} \\
\hline SNL-12_Core076.jpg & 7-09-03 & $\begin{array}{l}\text { SNL-12 drillpad; } \\
\text { T23S, R31E, } \\
\text { sec20 }\end{array}$ & \begin{tabular}{|l|} 
Close-up photo of Tamarisk (A2) Mbr \\
core, $546.7-548.1 \mathrm{ft}$ bgl, with markings, \\
scale, and time-date stamp
\end{tabular} & $\begin{array}{l}\text { DW Powers } \\
\text { Consultant to WTS }\end{array}$ \\
\hline SNL-12_Core077.jpg & 7-09-03 & $\begin{array}{l}\text { SNL-12 drillpad; } \\
\text { T23S, R31E, } \\
\text { sec20 }\end{array}$ & $\begin{array}{l}\text { Close-up photo of Tamarisk (A2) and } \\
\text { Culebra Dolomite Mbrs core, } 547.3-548.3 \\
\text { ft bgl, with markings, scale, and time-date } \\
\text { stamp }\end{array}$ & $\begin{array}{l}\text { DW Powers } \\
\text { Consultant to WTS }\end{array}$ \\
\hline SNL-12_Core078.jpg & 7-09-03 & $\begin{array}{l}\text { SNL-12 drillpad; } \\
\text { T23S, R31E, } \\
\text { sec20 }\end{array}$ & $\begin{array}{l}\text { Close-up photo of Culebra Dolomite Mbr } \\
\text { core, } 548.2 \text { - } 549.4 \mathrm{ft} \text { bgl, with markings, } \\
\text { scale, and time-date stamp }\end{array}$ & $\begin{array}{l}\text { DW Powers } \\
\text { Consultant to WTS }\end{array}$ \\
\hline SNL-12_Core079.jpg & 7-09-03 & $\begin{array}{l}\text { SNL-12 drillpad; } \\
\text { T23S, R31E, } \\
\text { sec20 }\end{array}$ & $\begin{array}{l}\text { Close-up photo of Culebra Dolomite Mbr } \\
\text { core, } 548.7-550.1 \mathrm{ft} \text { bgl, with markings, } \\
\text { scale, and time-date stamp }\end{array}$ & \begin{tabular}{|l} 
DW Powers \\
Consultant to WTS
\end{tabular} \\
\hline SNL-12_Core080.jpg & 7-09-03 & $\begin{array}{l}\text { SNL-12 drillpad; } \\
\text { T23S, R31E, } \\
\text { sec20 }\end{array}$ & $\begin{array}{l}\text { Close-up photo of Culebra Dolomite Mbr } \\
\text { core, } 549.7-551.1 \mathrm{ft} \text { bgl, with markings, } \\
\text { scale, and time-date stamp }\end{array}$ & $\begin{array}{l}\text { DW Powers } \\
\text { Consultant to WTS }\end{array}$ \\
\hline
\end{tabular}




\begin{tabular}{|c|c|c|c|c|}
\hline \multicolumn{5}{|c|}{ Photograph Log Sheet } \\
\hline File & DATE & LOCATION & $\begin{array}{l}\text { DESCRIPTION OF SUBJECT } \\
\text { (includes individual/group names, } \\
\text { direction, etc. as appropriate) }\end{array}$ & $\begin{array}{l}\text { PHOTOGRAPHER } \\
\text { (initials and dept.) }\end{array}$ \\
\hline SNL-12_Core081.jpg & $7-09-03$ & $\begin{array}{l}\text { SNL-12 drillpad; } \\
\text { T23S, R31E, } \\
\text { sec20 }\end{array}$ & $\begin{array}{l}\text { Close-up photo of Culebra Dolomite Mbr } \\
\text { core, } 550.7-552.1 \mathrm{ft} \text { bgl, with markings, } \\
\text { scale, and time-date stamp }\end{array}$ & $\begin{array}{l}\text { DW Powers } \\
\text { Consultant to WTS }\end{array}$ \\
\hline SNL-12_Core082.jpg & 7-09-03 & $\begin{array}{l}\text { SNL-12 drillpad; } \\
\text { T23S, R31E, } \\
\text { sec20 }\end{array}$ & $\begin{array}{l}\text { Close-up photo of Culebra Dolomite Mbr } \\
\text { core, } 551.7-553.3 \mathrm{ft} \text { bgl, with markings, } \\
\text { scale, and time-date stamp }\end{array}$ & $\begin{array}{l}\text { DW Powers } \\
\text { Consultant to WTS }\end{array}$ \\
\hline SNL-12_Core083.jpg & 7-09-03 & $\begin{array}{l}\text { SNL-12 drillpad; } \\
\text { T23S, R31E, } \\
\text { sec20 }\end{array}$ & $\begin{array}{l}\text { Close-up photo of Culebra Dolomite Mbr } \\
\text { core, } 552.7-554.2 \mathrm{ft} \text { bgl, with markings, } \\
\text { scale, and time-date stamp }\end{array}$ & $\begin{array}{l}\text { DW Powers } \\
\text { Consultant to WTS }\end{array}$ \\
\hline SNL-12_Core084.jpg & $7-09-03$ & $\begin{array}{l}\text { SNL-12 drillpad; } \\
\text { T23S, R31E, } \\
\text { sec20 }\end{array}$ & $\begin{array}{l}\text { Close-up photo of Culebra Dolomite Mbr } \\
\text { core, } 553.7-555.2 \mathrm{ft} \text { bgl, with markings, } \\
\text { scale, and time-date stamp }\end{array}$ & \begin{tabular}{|l} 
DW Powers \\
Consultant to WTS
\end{tabular} \\
\hline SNL-12_Core085.jpg & $7-09-03$ & $\begin{array}{l}\text { SNL-12 drillpad; } \\
\text { T23S, R31E, } \\
\text { sec20 }\end{array}$ & $\begin{array}{l}\text { Close-up photo of Culebra Dolomite Mbr } \\
\text { core, } 554.7-556.3 \mathrm{ft} \text { bgl, with markings, } \\
\text { scale, and time-date stamp }\end{array}$ & $\begin{array}{l}\text { DW Powers } \\
\text { Consultant to WTS }\end{array}$ \\
\hline SNL-12_Core086.jpg & 7-09-03 & $\begin{array}{l}\text { SNL-12 drillpad; } \\
\text { T23S, R31E, } \\
\text { sec20 }\end{array}$ & $\begin{array}{l}\text { Close-up photo of Culebra Dolomite Mbr } \\
\text { core, } 555.7-557.4 \mathrm{ft} \text { bgl, with markings, } \\
\text { scale, and time-date stamp }\end{array}$ & $\begin{array}{l}\text { DW Powers } \\
\text { Consultant to WTS }\end{array}$ \\
\hline SNL-12_Core087.jpg & 7-09-03 & $\begin{array}{l}\text { SNL-12 drillpad; } \\
\text { T23S, R31E, } \\
\text { sec20 }\end{array}$ & $\begin{array}{l}\text { Close-up photo of Culebra Dolomite Mbr } \\
\text { core, } 556.7-558.3 \mathrm{ft} \text { bgl, with markings, } \\
\text { scale, and time-date stamp }\end{array}$ & $\begin{array}{l}\text { DW Powers } \\
\text { Consultant to WTS }\end{array}$ \\
\hline SNL-12_Core088.jpg & $7-09-03$ & $\begin{array}{l}\text { SNL-12 drillpad; } \\
\text { T23S, R31E, } \\
\text { sec20 }\end{array}$ & $\begin{array}{l}\text { Close-up photo of Culebra Dolomite Mbr } \\
\text { core, } 557.6-559.2 \mathrm{ft} \text { bgl, with markings, } \\
\text { scale, and time-date stamp }\end{array}$ & $\begin{array}{l}\text { DW Powers } \\
\text { Consultant to WTS }\end{array}$ \\
\hline SNL-12_Core089.jpg & $7-09-03$ & $\begin{array}{l}\text { SNL-12 drillpad; } \\
\text { T23S, R31E, } \\
\text { sec20 }\end{array}$ & $\begin{array}{l}\text { Close-up photo of Culebra Dolomite Mbr } \\
\text { core, } 558.3-559.4 \mathrm{ft} \text { bgl, with markings, } \\
\text { scale, and time-date stamp }\end{array}$ & $\begin{array}{l}\text { DW Powers } \\
\text { Consultant to WTS }\end{array}$ \\
\hline SNL-12_Core090.jpg & $7-09-03$ & $\begin{array}{l}\text { SNL-12 drillpad; } \\
\text { T23S, R31E, } \\
\text { sec20 }\end{array}$ & $\begin{array}{l}\text { Close-up photo of Culebra Dolomite Mbr } \\
\text { core, } 559.3-560.3 \mathrm{ft} \text { bgl, with markings, } \\
\text { scale, and time-date stamp }\end{array}$ & $\begin{array}{l}\text { DW Powers } \\
\text { Consultant to WTS }\end{array}$ \\
\hline SNL-12_Core091.jpg & 7-09-03 & $\begin{array}{l}\text { SNL-12 drillpad; } \\
\text { T23S, R31E, } \\
\text { sec20 }\end{array}$ & $\begin{array}{l}\text { Close-up photo of Culebra Dolomite Mbr } \\
\text { core, } 559.7-561.1 \mathrm{ft} \text { bgl, with markings, } \\
\text { scale, and time-date stamp }\end{array}$ & $\begin{array}{l}\text { DW Powers } \\
\text { Consultant to WTS }\end{array}$ \\
\hline SNL-12_Core092.jpg & $7-09-03$ & $\begin{array}{l}\text { SNL-12 drillpad; } \\
\text { T23S, R31E, } \\
\text { sec20 }\end{array}$ & $\begin{array}{l}\text { Close-up photo of Culebra Dolomite Mbr } \\
\text { core, } 560.7-562.2 \mathrm{ft} \text { bgl, with markings, } \\
\text { scale, and time-date stamp }\end{array}$ & $\begin{array}{l}\text { DW Powers } \\
\text { Consultant to WTS }\end{array}$ \\
\hline SNL-12_Core093.jpg & 7-09-03 & $\begin{array}{l}\text { SNL-12 drillpad; } \\
\text { T23S, R31E, } \\
\text { sec20 }\end{array}$ & $\begin{array}{l}\text { Close-up photo of Culebra Dolomite Mbr } \\
\text { core, } 561.8-563.2 \mathrm{ft} \text { bgl, with markings, } \\
\text { scale, and time-date stamp }\end{array}$ & \begin{tabular}{|l} 
DW Powers \\
Consultant to WTS
\end{tabular} \\
\hline SNL-12_Core094.jpg & $7-09-03$ & $\begin{array}{l}\text { SNL-12 drillpad; } \\
\text { T23S, R31E, } \\
\text { sec20 }\end{array}$ & $\begin{array}{l}\text { Close-up photo of Culebra Dolomite Mbr } \\
\text { core, } 562.8-564.2 \mathrm{ft} \text { bgl, with markings, } \\
\text { scale, and time-date stamp }\end{array}$ & \begin{tabular}{|l} 
DW Powers \\
Consultant to WTS
\end{tabular} \\
\hline SNL-12_Core095.jpg & $7-09-03$ & $\begin{array}{l}\text { SNL-12 drillpad; } \\
\text { T23S, R31E, } \\
\text { sec20 }\end{array}$ & $\begin{array}{l}\text { Close-up photo of Culebra Dolomite Mbr } \\
\text { core, } 563.7-565.1 \mathrm{ft} \text { bgl, with markings, } \\
\text { scale, and time-date stamp }\end{array}$ & \begin{tabular}{|l} 
DW Powers \\
Consultant to WTS
\end{tabular} \\
\hline SNL-12_Core096.jpg & $7-09-03$ & $\begin{array}{l}\text { SNL-12 drillpad; } \\
\text { T23S, R31E, } \\
\text { sec20 }\end{array}$ & $\begin{array}{l}\text { Close-up photo of Culebra Dolomite Mbr } \\
\text { core, } 564.8-566.2 \mathrm{ft} \text { bgl, with markings, } \\
\text { scale, and time-date stamp }\end{array}$ & $\begin{array}{l}\text { DW Powers } \\
\text { Consultant to WTS }\end{array}$ \\
\hline
\end{tabular}




\begin{tabular}{|c|c|c|c|c|}
\hline \multicolumn{5}{|c|}{ Photograph Log Sheet } \\
\hline File & DATE & LOCATION & $\begin{array}{l}\text { DESCRIPTION OF SUBJECT } \\
\text { (includes individual/group names, } \\
\text { direction, etc. as appropriate) }\end{array}$ & $\begin{array}{l}\text { PHOTOGRAPHER } \\
\text { (initials and dept.) }\end{array}$ \\
\hline SNL-12_Core097.jpg & 7-09-03 & $\begin{array}{l}\text { SNL-12 drillpad; } \\
\text { T23S, R31E, } \\
\text { sec20 }\end{array}$ & $\begin{array}{l}\text { Close-up photo of Culebra Dolomite Mbr } \\
\text { core, } 565.8-567.2 \mathrm{ft} \text { bgl, with markings, } \\
\text { scale, and time-date stamp }\end{array}$ & $\begin{array}{l}\text { DW Powers } \\
\text { Consultant to WTS }\end{array}$ \\
\hline SNL-12_Core098.jpg & 7-09-03 & $\begin{array}{l}\text { SNL-12 drillpad; } \\
\text { T23S, R31E, } \\
\text { sec20 }\end{array}$ & $\begin{array}{l}\text { Close-up photo of Culebra Dolomite Mbr } \\
\text { core, } 566.7-568.1 \mathrm{ft} \text { bgl, with markings, } \\
\text { scale, and time-date stamp }\end{array}$ & $\begin{array}{l}\text { DW Powers } \\
\text { Consultant to WTS }\end{array}$ \\
\hline SNL-12_Core099.jpg & 7-09-03 & $\begin{array}{l}\text { SNL-12 drillpad; } \\
\text { T23S, R31E, } \\
\text { sec20 }\end{array}$ & $\begin{array}{l}\text { Close-up photo of Culebra Dolomite Mbr } \\
\text { core, } 567.7-569.1 \mathrm{ft} \text { bgl, with markings, } \\
\text { scale, and time-date stamp }\end{array}$ & $\begin{array}{l}\text { DW Powers } \\
\text { Consultant to WTS }\end{array}$ \\
\hline SNL-12_Core100.jpg & 7-09-03 & $\begin{array}{l}\text { SNL-12 drillpad; } \\
\text { T23S, R31E, } \\
\text { sec20 }\end{array}$ & $\begin{array}{l}\text { Close-up photo of Culebra Dolomite Mbr } \\
\text { core, } 568.7-570.1 \mathrm{ft} \text { bgl, with markings, } \\
\text { scale, and time-date stamp }\end{array}$ & $\begin{array}{l}\text { DW Powers } \\
\text { Consultant to WTS }\end{array}$ \\
\hline SNL-12_Core101.jpg & $7-09-03$ & $\begin{array}{l}\text { SNL-12 drillpad; } \\
\text { T23S, R31E, } \\
\text { sec20 }\end{array}$ & $\begin{array}{l}\text { Close-up photo of Culebra Dolomite Mbr } \\
\text { core, } 569.8-571.2 \mathrm{ft} \text { bgl, with markings, } \\
\text { scale, and time-date stamp }\end{array}$ & $\begin{array}{l}\text { DW Powers } \\
\text { Consultant to WTS }\end{array}$ \\
\hline SNL-12_Core102.jpg & 7-09-03 & $\begin{array}{l}\text { SNL-12 drillpad; } \\
\text { T23S, R31E, } \\
\text { sec20 }\end{array}$ & $\begin{array}{l}\text { Close-up photo of Culebra Dolomite Mbr } \\
\text { core, } 570.9-572.2 \mathrm{ft} \text { bgl, with markings, } \\
\text { scale, and time-date stamp }\end{array}$ & $\begin{array}{l}\text { DW Powers } \\
\text { Consultant to WTS }\end{array}$ \\
\hline SNL-12_Core103.jpg & 7-09-03 & $\begin{array}{l}\text { SNL-12 drillpad; } \\
\text { T23S, R31E, } \\
\text { sec20 }\end{array}$ & $\begin{array}{l}\text { Close-up photo of Culebra Dolomite Mbr } \\
\text { core, } 571.8-573.1 \mathrm{ft} \text { bgl, with markings, } \\
\text { scale, and time-date stamp }\end{array}$ & $\begin{array}{l}\text { DW Powers } \\
\text { Consultant to WTS }\end{array}$ \\
\hline SNL-12_Core104.jpg & $7-09-03$ & $\begin{array}{l}\text { SNL-12 drillpad; } \\
\text { T23S, R31E, } \\
\text { sec20 }\end{array}$ & $\begin{array}{l}\text { Close-up photo of Culebra Dolomite Mbr } \\
\text { core, } 572.8-574.2 \mathrm{ft} \text { bgl, with markings, } \\
\text { scale, and time-date stamp }\end{array}$ & $\begin{array}{l}\text { DW Powers } \\
\text { Consultant to WTS }\end{array}$ \\
\hline SNL-12_Core105.jpg & 7-09-03 & $\begin{array}{l}\text { SNL-12 drillpad; } \\
\text { T23S, R31E, } \\
\text { sec20 }\end{array}$ & $\begin{array}{l}\text { Close-up photo of Culebra Dolomite Mbr } \\
\text { core, } 573.8-575.1 \mathrm{ft} \text { bgl, with markings, } \\
\text { scale, and time-date stamp }\end{array}$ & $\begin{array}{l}\text { DW Powers } \\
\text { Consultant to WTS }\end{array}$ \\
\hline SNL-12_Core106.jpg & 7-09-03 & $\begin{array}{l}\text { SNL-12 drillpad; } \\
\text { T23S, R31E, } \\
\text { sec20 }\end{array}$ & $\begin{array}{l}\text { Close-up photo of Culebra Dolomite Mbr } \\
\text { core, } 574.8-576.2 \mathrm{ft} \text { bgl, with markings, } \\
\text { scale, and time-date stamp }\end{array}$ & $\begin{array}{l}\text { DW Powers } \\
\text { Consultant to WTS }\end{array}$ \\
\hline SNL-12_Core107.jpg & $7-09-03$ & $\begin{array}{l}\text { SNL-12 drillpad; } \\
\text { T23S, R31E, } \\
\text { sec20 }\end{array}$ & $\begin{array}{l}\text { Close-up photo of Culebra Dolomite Mbr } \\
\text { core, } 575.8-577.3 \mathrm{ft} \text { bgl, with markings, } \\
\text { scale, and time-date stamp }\end{array}$ & $\begin{array}{l}\text { DW Powers } \\
\text { Consultant to WTS }\end{array}$ \\
\hline SNL-12_Core108.jpg & $7-10-03$ & $\begin{array}{l}\text { SNL-12 drillpad; } \\
\text { T23S, R31E, } \\
\text { sec20 }\end{array}$ & $\begin{array}{l}\text { Close-up photo of Culebra Dolomite Mbr } \\
\text { core, } 576.9-578.1 \mathrm{ft} \text { bgl, with markings, } \\
\text { scale, and time-date stamp }\end{array}$ & $\begin{array}{l}\text { DW Powers } \\
\text { Consultant to WTS }\end{array}$ \\
\hline SNL-12_Core109.jpg & $7-10-03$ & $\begin{array}{l}\text { SNL-12 drillpad; } \\
\text { T23S, R31E, } \\
\text { sec20 }\end{array}$ & $\begin{array}{l}\text { Close-up photo of Culebra Dolomite Mbr } \\
\text { core, } 577.9-579.1 \mathrm{ft} \text { bgl, with markings, } \\
\text { scale, and time-date stamp }\end{array}$ & $\begin{array}{l}\text { DW Powers } \\
\text { Consultant to WTS }\end{array}$ \\
\hline SNL-12_Core110.jpg & $7-10-03$ & $\begin{array}{l}\text { SNL-12 drillpad; } \\
\text { T23S, R31E, } \\
\text { sec20 }\end{array}$ & $\begin{array}{l}\text { Close-up photo of Culebra Dolomite Mbr } \\
\text { core, } 578.9-580.1 \mathrm{ft} \text { bgl, with markings, } \\
\text { scale, and time-date stamp }\end{array}$ & $\begin{array}{l}\text { DW Powers } \\
\text { Consultant to WTS }\end{array}$ \\
\hline SNL-12_Core111.jpg & $7-10-03$ & $\begin{array}{l}\text { SNL-12 drillpad; } \\
\text { T23S, R31E, } \\
\text { sec20 }\end{array}$ & $\begin{array}{l}\text { Close-up photo of Culebra Dolomite Mbr } \\
\text { core, } 579.9-581.2 \mathrm{ft} \text { bgl, with markings, } \\
\text { scale, and time-date stamp }\end{array}$ & \begin{tabular}{|l} 
DW Powers \\
Consultant to WTS
\end{tabular} \\
\hline SNL-12_Core112.jpg & $7-10-03$ & $\begin{array}{l}\text { SNL-12 drillpad; } \\
\text { T23S, R31E, } \\
\text { sec20 }\end{array}$ & $\begin{array}{l}\text { Close-up photo of Culebra Dolomite Mbr } \\
\text { core, } 580.9-582.0 \mathrm{ft} \text { bgl, with markings, } \\
\text { scale, and time-date stamp }\end{array}$ & $\begin{array}{l}\text { DW Powers } \\
\text { Consultant to WTS }\end{array}$ \\
\hline
\end{tabular}




\begin{tabular}{|c|c|c|c|c|}
\hline \multicolumn{5}{|c|}{ Photograph Log Sheet } \\
\hline File & DATE & LOCATION & $\begin{array}{l}\text { DESCRIPTION OF SUBJECT } \\
\text { (includes individual/group names, } \\
\text { direction, etc. as appropriate) }\end{array}$ & $\begin{array}{l}\text { PHOTOGRAPHER } \\
\text { (initials and dept.) }\end{array}$ \\
\hline SNL-12_Core113.jpg & $7-10-03$ & $\begin{array}{l}\text { SNL-12 drillpad; } \\
\text { T23S, R31E, } \\
\text { sec20 }\end{array}$ & $\begin{array}{l}\text { Close-up photo of Culebra Dolomite Mbr } \\
\text { core, } 582.0-583.2 \mathrm{ft} \text { bgl, with markings, } \\
\text { scale, and time-date stamp }\end{array}$ & $\begin{array}{l}\text { DW Powers } \\
\text { Consultant to WTS }\end{array}$ \\
\hline SNL-12_Core114.jpg & \begin{tabular}{|l|}
$7-10-03$ \\
\end{tabular} & $\begin{array}{l}\text { SNL-12 drillpad; } \\
\text { T23S, R31E, } \\
\text { sec20 }\end{array}$ & $\begin{array}{l}\text { Close-up photo of Culebra Dolomite Mbr } \\
\text { core, } 582.9 \text { - } 584.1 \mathrm{ft} \text { bgl, with markings, } \\
\text { scale, and time-date stamp }\end{array}$ & $\begin{array}{l}\text { DW Powers } \\
\text { Consultant to WTS }\end{array}$ \\
\hline SNL-12_Core115.jpg & 7-10-03 & $\begin{array}{l}\text { SNL-12 drillpad; } \\
\text { T23S, R31E, } \\
\text { sec20 }\end{array}$ & $\begin{array}{l}\text { Close-up photo of Culebra Dolomite Mbr } \\
\text { core, } 583.8-585.2 \mathrm{ft} \text { bgl, with markings, } \\
\text { scale, and time-date stamp }\end{array}$ & $\begin{array}{l}\text { DW Powers } \\
\text { Consultant to WTS }\end{array}$ \\
\hline SNL-12_Core116.jpg & $7-10-03$ & $\begin{array}{l}\text { SNL-12 drillpad; } \\
\text { T23S, R31E, } \\
\text { sec20 }\end{array}$ & $\begin{array}{l}\text { Close-up photo of Culebra Dolomite Mbr } \\
\text { core, } 584.8-586.2 \mathrm{ft} \text { bgl, with markings, } \\
\text { scale, and time-date stamp }\end{array}$ & $\begin{array}{l}\text { DW Powers } \\
\text { Consultant to WTS }\end{array}$ \\
\hline SNL-12_Core117.jpg & \begin{tabular}{|l|}
$7-10-03$ \\
\end{tabular} & $\begin{array}{l}\text { SNL-12 drillpad; } \\
\text { T23S, R31E, } \\
\text { sec20 }\end{array}$ & $\begin{array}{l}\text { Close-up photo of Culebra Dolomite Mbr } \\
\text { core, } 585.8 \text { - } 587.1 \mathrm{ft} \text { bgl, with markings, } \\
\text { scale, and time-date stamp }\end{array}$ & $\begin{array}{l}\text { DW Powers } \\
\text { Consultant to WTS }\end{array}$ \\
\hline SNL-12_Core118.jpg & \begin{tabular}{|l|}
$7-10-03$ \\
\end{tabular} & $\begin{array}{l}\text { SNL-12 drillpad; } \\
\text { T23S, R31E, } \\
\text { sec20 }\end{array}$ & $\begin{array}{l}\text { Close-up photo of Culebra Dolomite Mbr } \\
\text { core, } 586.8 \text { - } 588.1 \mathrm{ft} \text { bgl, with markings, } \\
\text { scale, and time-date stamp }\end{array}$ & $\begin{array}{l}\text { DW Powers } \\
\text { Consultant to WTS }\end{array}$ \\
\hline SNL-12_Core119.jpg & 7-09-03 & $\begin{array}{l}\text { SNL-12 drillpad; } \\
\text { T23S, R31E, } \\
\text { sec20 }\end{array}$ & $\begin{array}{l}\text { Close-up photo of Culebra Dolomite and } \\
\text { Los Medaños (M2/H2) Mbrs core, } 587.8 \text { - } \\
589.1 \mathrm{ft} \text { bgl, with markings, scale, and } \\
\text { time-date stamp }\end{array}$ & $\begin{array}{l}\text { DW Powers } \\
\text { Consultant to WTS }\end{array}$ \\
\hline SNL-12_Core120.jpg & \begin{tabular}{|l|}
$7-10-03$ \\
\end{tabular} & $\begin{array}{l}\text { SNL-12 drillpad; } \\
\text { T23S, R31E, } \\
\text { sec20 }\end{array}$ & $\begin{array}{l}\text { Close-up photo of Los Medaños (M2/H2) } \\
\text { Mbr core, } 588.9-590.1 \mathrm{ft} \text { bgl, with } \\
\text { markings, scale, and time-date stamp }\end{array}$ & $\begin{array}{l}\text { DW Powers } \\
\text { Consultant to WTS }\end{array}$ \\
\hline SNL-12_Core121.jpg & $7-10-03$ & $\begin{array}{l}\text { SNL-12 drillpad; } \\
\text { T23S, R31E, } \\
\text { sec20 }\end{array}$ & $\begin{array}{l}\text { Close-up photo of Los Medaños (M2/H2) } \\
\text { Mbr core, } 589.9-591.2 \mathrm{ft} \text { bgl, with } \\
\text { markings, scale, and time-date stamp }\end{array}$ & \begin{tabular}{|l} 
DW Powers \\
Consultant to WTS
\end{tabular} \\
\hline SNL-12_Core122.jpg & 7-10-03 & $\begin{array}{l}\text { SNL-12 drillpad; } \\
\text { T23S, R31E, } \\
\text { sec20 }\end{array}$ & $\begin{array}{l}\text { Close-up photo of Los Medaños (M2/H2) } \\
\text { Mbr core, } 590.8-592.1 \mathrm{ft} \text { bgl, with } \\
\text { markings, scale, and time-date stamp }\end{array}$ & $\begin{array}{l}\text { DW Powers } \\
\text { Consultant to WTS }\end{array}$ \\
\hline SNL-12_Core123.jpg & $7-10-03$ & $\begin{array}{l}\text { SNL-12 drillpad; } \\
\text { T23S, R31E, } \\
\text { sec20 }\end{array}$ & $\begin{array}{l}\text { Close-up photo of Los Medaños (M2/H2) } \\
\text { Mbr core, } 591.8 \text { - } 593.1 \mathrm{ft} \text { bgl, with } \\
\text { markings, scale, and time-date stamp }\end{array}$ & $\begin{array}{l}\text { DW Powers } \\
\text { Consultant to WTS }\end{array}$ \\
\hline SNL-12_Core124.jpg & $7-10-03$ & $\begin{array}{l}\text { SNL-12 drillpad; } \\
\text { T23S, R31E, } \\
\text { sec20 }\end{array}$ & $\begin{array}{l}\text { Close-up photo of Los Medaños (M2/H2) } \\
\text { Mbr core, } 592.8-594.1 \mathrm{ft} \text { bgl, with } \\
\text { markings, scale, and time-date stamp }\end{array}$ & $\begin{array}{l}\text { DW Powers } \\
\text { Consultant to WTS }\end{array}$ \\
\hline SNL-12_Core125.jpg & \begin{tabular}{|l|}
$7-10-03$ \\
\end{tabular} & $\begin{array}{l}\text { SNL-12 drillpad; } \\
\text { T23S, R31E, } \\
\text { sec20 }\end{array}$ & $\begin{array}{l}\text { Close-up photo of Los Medaños (M2/H2) } \\
\text { Mbr core, } 593.9-595.2 \mathrm{ft} \text { bgl, with } \\
\text { markings, scale, and time-date stamp }\end{array}$ & \begin{tabular}{|l} 
DW Powers \\
Consultant to WTS
\end{tabular} \\
\hline SNL-12_Core126.jpg & $7-10-03$ & $\begin{array}{l}\text { SNL-12 drillpad; } \\
\text { T23S, R31E, } \\
\text { sec20 }\end{array}$ & $\begin{array}{l}\text { Close-up photo of Los Medaños (M2/H2) } \\
\text { Mbr core, } 594.9-596.2 \mathrm{ft} \text { bgl, with } \\
\text { markings, scale, and time-date stamp }\end{array}$ & \begin{tabular}{|l} 
DW Powers \\
Consultant to WTS
\end{tabular} \\
\hline SNL-12_Core127.jpg & $7-10-03$ & $\begin{array}{l}\text { SNL-12 drillpad; } \\
\text { T23S, R31E, } \\
\text { sec20 }\end{array}$ & $\begin{array}{l}\text { Close-up photo of Los Medaños (M2/H2) } \\
\text { Mbr core, } 595.8 \text { - } 597.2 \mathrm{ft} \text { bgl, with } \\
\text { markings, scale, and time-date stamp }\end{array}$ & $\begin{array}{l}\text { DW Powers } \\
\text { Consultant to WTS }\end{array}$ \\
\hline SNL-12_Core128.jpg & $7-10-03$ & $\begin{array}{l}\text { SNL-12 drillpad; } \\
\text { T23S, R31E, } \\
\text { sec20 }\end{array}$ & $\begin{array}{l}\text { Close-up photo of Los Medaños (M2/H2) } \\
\text { Mbr core, } 596.8 \text { - } 598.2 \mathrm{ft} \text { bgl, with } \\
\text { markings, scale, and time-date stamp }\end{array}$ & $\begin{array}{l}\text { DW Powers } \\
\text { Consultant to WTS }\end{array}$ \\
\hline
\end{tabular}




\begin{tabular}{|c|c|c|c|c|}
\hline \multicolumn{5}{|c|}{ Photograph Log Sheet } \\
\hline File & DATE & LOCATION & $\begin{array}{l}\text { DESCRIPTION OF SUBJECT } \\
\text { (includes individual/group names, } \\
\text { direction, etc. as appropriate) }\end{array}$ & $\begin{array}{l}\text { PHOTOGRAPHER } \\
\text { (initials and dept.) }\end{array}$ \\
\hline SNL-12_Core129.jpg & 7-10-03 & $\begin{array}{l}\text { SNL-12 drillpad; } \\
\text { T23S, R31E, } \\
\text { sec20 }\end{array}$ & $\begin{array}{l}\text { Close-up photo of Los Medaños (M2/H2) } \\
\text { Mbr core, } 597.9-599.2 \mathrm{ft} \text { bgl, with } \\
\text { markings, scale, and time-date stamp }\end{array}$ & \begin{tabular}{|l} 
DW Powers \\
Consultant to WTS
\end{tabular} \\
\hline SNL-12_Core130.jpg & $7-10-03$ & $\begin{array}{l}\text { SNL-12 drillpad; } \\
\text { T23S, R31E, } \\
\text { sec20 }\end{array}$ & $\begin{array}{l}\text { Close-up photo of Los Medaños (M2/H2) } \\
\text { Mbr core, } 598.8-600.0 \mathrm{ft} \text { bgl, with } \\
\text { markings, scale, and time-date stamp }\end{array}$ & \begin{tabular}{|l} 
DW Powers \\
Consultant to WTS
\end{tabular} \\
\hline SNL-12_Core131.jpg & 7-11-03 & $\begin{array}{l}\text { SNL-12 drillpad; } \\
\text { T23S, R31E, } \\
\text { sec20 }\end{array}$ & $\begin{array}{l}\text { Close-up photo of Los Medaños (M2/H2 \& } \\
\text { A1) Mbr core, } 600.0-601.2 \mathrm{ft} \text { bgl, with } \\
\text { markings, scale, and time-date stamp }\end{array}$ & $\begin{array}{l}\text { DW Powers } \\
\text { Consultant to WTS }\end{array}$ \\
\hline SNL-12_Core132.jpg & $7-11-03$ & $\begin{array}{l}\text { SNL-12 drillpad; } \\
\text { T23S, R31E, } \\
\text { sec20 }\end{array}$ & $\begin{array}{l}\text { Close-up photo of Los Medaños (A1) Mbr } \\
\text { core, } 600.9-602.1 \mathrm{ft} \text { bgl, with markings, } \\
\text { scale, and time-date stamp }\end{array}$ & \begin{tabular}{|l} 
DW Powers \\
Consultant to WTS
\end{tabular} \\
\hline SNL-12_Core133.jpg & 7-11-03 & $\begin{array}{l}\text { SNL-12 drillpad; } \\
\text { T23S, R31E, } \\
\text { sec20 }\end{array}$ & $\begin{array}{l}\text { Close-up photo of Los Medaños (A1) Mbr } \\
\text { core, } 601.9-603.1 \mathrm{ft} \text { bgl, with markings, } \\
\text { scale, and time-date stamp }\end{array}$ & \begin{tabular}{|l} 
DW Powers \\
Consultant to WTS
\end{tabular} \\
\hline SNL-12_Core134.jpg & $7-11-03$ & $\begin{array}{l}\text { SNL-12 drillpad; } \\
\text { T23S, R31E, } \\
\text { sec20 }\end{array}$ & $\begin{array}{l}\text { Close-up photo of Los Medaños (A1) Mbr } \\
\text { core, } 602.9-604.1 \mathrm{ft} \text { bgl, with markings, } \\
\text { scale, and time-date stamp }\end{array}$ & \begin{tabular}{|l} 
DW Powers \\
Consultant to WTS
\end{tabular} \\
\hline SNL-12_Core135.jpg & 7-11-03 & $\begin{array}{l}\text { SNL-12 drillpad; } \\
\text { T23S, R31E, } \\
\text { sec20 }\end{array}$ & $\begin{array}{l}\text { Close-up photo of Los Medaños (A1) Mbr } \\
\text { core, } 603.8 \text { - } 605.1 \mathrm{ft} \text { bgl, with markings, } \\
\text { scale, and time-date stamp }\end{array}$ & $\begin{array}{l}\text { DW Powers } \\
\text { Consultant to WTS }\end{array}$ \\
\hline SNL-12_Core136.jpg & 7-11-03 & $\begin{array}{l}\text { SNL-12 drillpad; } \\
\text { T23S, R31E, } \\
\text { sec20 }\end{array}$ & $\begin{array}{l}\text { Close-up photo of Los Medaños (A1) Mbr } \\
\text { core, } 604.9 \text { - } 606.2 \mathrm{ft} \text { bgl, with markings, } \\
\text { scale, and time-date stamp }\end{array}$ & \begin{tabular}{|l} 
DW Powers \\
Consultant to WTS
\end{tabular} \\
\hline SNL-12_Core137.jpg & 7-11-03 & $\begin{array}{l}\text { SNL-12 drillpad; } \\
\text { T23S, R31E, } \\
\text { sec20 }\end{array}$ & $\begin{array}{l}\text { Close-up photo of Los Medaños (A1) Mbr } \\
\text { core, } 605.9 \text { - } 607.2 \mathrm{ft} \text { bgl, with markings, } \\
\text { scale, and time-date stamp }\end{array}$ & \begin{tabular}{|l|} 
DW Powers \\
Consultant to WTS
\end{tabular} \\
\hline SNL-12_Core138.jpg & 7-11-03 & $\begin{array}{l}\text { SNL-12 drillpad; } \\
\text { T23S, R31E, } \\
\text { sec20 }\end{array}$ & $\begin{array}{l}\text { Close-up photo of Los Medaños (A1) Mbr } \\
\text { core, } 606.8-608.1 \mathrm{ft} \text { bgl, with markings, } \\
\text { scale, and time-date stamp }\end{array}$ & \begin{tabular}{|l} 
DW Powers \\
Consultant to WTS
\end{tabular} \\
\hline SNL-12_Core139.jpg & 7-11-03 & $\begin{array}{l}\text { SNL-12 drillpad; } \\
\text { T23S, R31E, } \\
\text { sec20 }\end{array}$ & $\begin{array}{l}\text { Close-up photo of Los Medaños (A1) Mbr } \\
\text { core, } 607.9-609.1 \mathrm{ft} \text { bgl, with markings, } \\
\text { scale, and time-date stamp }\end{array}$ & \begin{tabular}{|l} 
DW Powers \\
Consultant to WTS
\end{tabular} \\
\hline SNL-12_Core140.jpg & 7-11-03 & $\begin{array}{l}\text { SNL-12 drillpad; } \\
\text { T23S, R31E, } \\
\text { sec20 }\end{array}$ & $\begin{array}{l}\text { Close-up photo of Los Medaños (A1 and } \\
\text { M1/H1) Mbr core, } 608.9-610.3 \mathrm{ft} \text { bgl, with } \\
\text { markings, scale, and time-date stamp }\end{array}$ & $\begin{array}{l}\text { DW Powers } \\
\text { Consultant to WTS }\end{array}$ \\
\hline SNL-12_Core141.jpg & $7-11-03$ & $\begin{array}{l}\text { SNL-12 drillpad; } \\
\text { T23S, R31E, } \\
\text { sec20 }\end{array}$ & $\begin{array}{l}\text { Close-up photo of Los Medaños (M1/H1) } \\
\text { Mbr core, } 620.0-621.4 \mathrm{ft} \text { bgl, with } \\
\text { markings, scale, and time-date stamp }\end{array}$ & \begin{tabular}{|l} 
DW Powers \\
Consultant to WTS
\end{tabular} \\
\hline SNL-12_Core142.jpg & 7-11-03 & $\begin{array}{l}\text { SNL-12 drillpad; } \\
\text { T23S, R31E, } \\
\text { sec20 }\end{array}$ & $\begin{array}{l}\text { Close-up photo of Los Medaños (M1/H1) } \\
\text { Mbr core, } 620.9-622.3 \mathrm{ft} \text { bgl, with } \\
\text { markings, scale, and time-date stamp }\end{array}$ & \begin{tabular}{|l} 
DW Powers \\
Consultant to WTS
\end{tabular} \\
\hline SNL-12_Core143.jpg & $7-11-03$ & $\begin{array}{l}\text { SNL-12 drillpad; } \\
\text { T23S, R31E, } \\
\text { sec20 }\end{array}$ & $\begin{array}{l}\text { Close-up photo of Los Medaños (M1/H1) } \\
\text { Mbr core, } 621.9 \text { - } 623.3 \mathrm{ft} \text { bgl, with } \\
\text { markings, scale, and time-date stamp }\end{array}$ & \begin{tabular}{|l|} 
DW Powers \\
Consultant to WTS
\end{tabular} \\
\hline SNL-12_Core144.jpg & 7-11-03 & $\begin{array}{l}\text { SNL-12 drillpad; } \\
\text { T23S, R31E, } \\
\text { sec20 }\end{array}$ & $\begin{array}{l}\text { Close-up photo of Los Medaños (M1/H1) } \\
\text { Mbr core, } 622.8 \text { - } 624.0 \mathrm{ft} \text { bgl, with } \\
\text { markings, scale, and time-date stamp }\end{array}$ & \begin{tabular}{|l|} 
DW Powers \\
Consultant to WTS
\end{tabular} \\
\hline
\end{tabular}




\begin{tabular}{|c|c|c|c|c|}
\hline \multicolumn{5}{|c|}{ Photograph Log Sheet } \\
\hline File & DATE & LOCATION & $\begin{array}{l}\text { DESCRIPTION OF SUBJECT } \\
\text { (includes individual/group names, } \\
\text { direction, etc. as appropriate) }\end{array}$ & $\begin{array}{l}\text { PHOTOGRAPHER } \\
\text { (initials and dept.) }\end{array}$ \\
\hline SNL-12_Core145.jpg & 7-11-03 & $\begin{array}{l}\text { SNL-12 drillpad; } \\
\text { T23S, R31E, } \\
\text { sec20 } \\
\end{array}$ & $\begin{array}{l}\text { Close-up photo of Los Medaños (M1/H1) } \\
\text { Mbr core, } 623.9 \text { - } 625.2 \mathrm{ft} \text { bgl, with } \\
\text { markings, scale, and time-date stamp }\end{array}$ & $\begin{array}{l}\text { DW Powers } \\
\text { Consultant to WTS }\end{array}$ \\
\hline SNL-12_Core146.jpg & 7-11-03 & $\begin{array}{l}\text { SNL-12 drillpad; } \\
\text { T23S, R31E, } \\
\text { sec20 }\end{array}$ & $\begin{array}{l}\text { Close-up photo of Los Medaños (M1/H1) } \\
\text { Mbr core, } 624.8-626.2 \mathrm{ft} \text { bgl, with } \\
\text { markings, scale, and time-date stamp }\end{array}$ & $\begin{array}{l}\text { DW Powers } \\
\text { Consultant to WTS }\end{array}$ \\
\hline SNL-12_Core147.jpg & 7-11-03 & $\begin{array}{l}\text { SNL-12 drillpad; } \\
\text { T23S, R31E, } \\
\text { sec20 }\end{array}$ & $\begin{array}{l}\text { Close-up photo of Los Medaños (M1/H1) } \\
\text { Mbr core, } 625.8 \text { - } 627.2 \mathrm{ft} \text { bgl, with } \\
\text { markings, scale, and time-date stamp }\end{array}$ & $\begin{array}{l}\text { DW Powers } \\
\text { Consultant to WTS }\end{array}$ \\
\hline SNL-12_Core148.jpg & 7-11-03 & $\begin{array}{l}\text { SNL-12 drillpad; } \\
\text { T23S, R31E, } \\
\text { sec20 }\end{array}$ & $\begin{array}{l}\text { Close-up photo of Los Medaños (M1/H1) } \\
\text { Mbr core, } 626.8-628.1 \mathrm{ft} \text { bgl, with } \\
\text { markings, scale, and time-date stamp }\end{array}$ & $\begin{array}{l}\text { DW Powers } \\
\text { Consultant to WTS }\end{array}$ \\
\hline SNL-12_Core149.jpg & 7-11-03 & $\begin{array}{l}\text { SNL-12 drillpad; } \\
\text { T23S, R31E, } \\
\text { sec20 } \\
\end{array}$ & $\begin{array}{l}\text { Close-up photo of Los Medaños (M1/H1) } \\
\text { Mbr core, } 627.8 \text { - } 629.2 \mathrm{ft} \text { bgl, with } \\
\text { markings, scale, and time-date stamp }\end{array}$ & $\begin{array}{l}\text { DW Powers } \\
\text { Consultant to WTS }\end{array}$ \\
\hline SNL-12_Core150.jpg & 7-11-03 & $\begin{array}{l}\text { SNL-12 drillpad; } \\
\text { T23S, R31E, } \\
\text { sec20 }\end{array}$ & $\begin{array}{l}\text { Close-up photo of Los Medaños (M1/H1) } \\
\text { Mbr core, } 628.8 \text { - } 630.1 \mathrm{ft} \text { bgl, with } \\
\text { markings, scale, and time-date stamp }\end{array}$ & $\begin{array}{l}\text { DW Powers } \\
\text { Consultant to WTS }\end{array}$ \\
\hline SNL-12_Core151.jpg & 7-11-03 & $\begin{array}{l}\text { SNL-12 drillpad; } \\
\text { T23S, R31E, } \\
\text { sec20 }\end{array}$ & $\begin{array}{l}\text { Close-up photo of Los Medaños (M1/H1) } \\
\text { Mbr core, } 629.8 \text { - } 631.2 \mathrm{ft} \text { bgl, with } \\
\text { markings, scale, and time-date stamp }\end{array}$ & $\begin{array}{l}\text { DW Powers } \\
\text { Consultant to WTS }\end{array}$ \\
\hline SNL-12_Core152.jpg & 7-11-03 & $\begin{array}{l}\text { SNL-12 drillpad; } \\
\text { T23S, R31E, } \\
\text { sec20 }\end{array}$ & $\begin{array}{l}\text { Close-up photo of Los Medaños (M1/H1) } \\
\text { Mbr core, } 630.8-632.1 \mathrm{ft} \text { bgl, with } \\
\text { markings, scale, and time-date stamp }\end{array}$ & $\begin{array}{l}\text { DW Powers } \\
\text { Consultant to WTS }\end{array}$ \\
\hline SNL-12_Core153.jpg & $7-11-03$ & $\begin{array}{l}\text { SNL-12 drillpad; } \\
\text { T23S, R31E, } \\
\text { sec20 } \\
\end{array}$ & $\begin{array}{l}\text { Close-up photo of Los Medaños (M1/H1) } \\
\text { Mbr core, } 631.8-633.2 \mathrm{ft} \text { bgl, with } \\
\text { markings, scale, and time-date stamp }\end{array}$ & $\begin{array}{l}\text { DW Powers } \\
\text { Consultant to WTS }\end{array}$ \\
\hline SNL-12_Core154.jpg & 7-11-03 & $\begin{array}{l}\text { SNL-12 drillpad; } \\
\text { T23S, R31E, } \\
\text { sec20 }\end{array}$ & $\begin{array}{l}\text { Close-up photo of Los Medaños (M1/H1) } \\
\text { Mbr core, } 632.8 \text { - } 634.2 \mathrm{ft} \text { bgl, with } \\
\text { markings, scale, and time-date stamp }\end{array}$ & $\begin{array}{l}\text { DW Powers } \\
\text { Consultant to WTS }\end{array}$ \\
\hline SNL-12_Core155.jpg & $7-11-03$ & $\begin{array}{l}\text { SNL-12 drillpad; } \\
\text { T23S, R31E, } \\
\text { sec20 }\end{array}$ & $\begin{array}{l}\text { Close-up photo of Los Medaños (M1/H1) } \\
\text { Mbr core, } 633.8 \text { - } 635.2 \mathrm{ft} \text { bgl, with } \\
\text { markings, scale, and time-date stamp }\end{array}$ & $\begin{array}{l}\text { DW Powers } \\
\text { Consultant to WTS }\end{array}$ \\
\hline SNL-12_Core156.jpg & 7-11-03 & $\begin{array}{l}\text { SNL-12 drillpad; } \\
\text { T23S, R31E, } \\
\text { sec20 }\end{array}$ & $\begin{array}{l}\text { Close-up photo of Los Medaños (M1/H1) } \\
\text { Mbr core, } 634.8-636.1 \mathrm{ft} \text { bgl, with } \\
\text { markings, scale, and time-date stamp }\end{array}$ & $\begin{array}{l}\text { DW Powers } \\
\text { Consultant to WTS }\end{array}$ \\
\hline SNL-12_Core157.jpg & 7-11-03 & $\begin{array}{l}\text { SNL-12 drillpad; } \\
\text { T23S, R31E, } \\
\text { sec20 }\end{array}$ & $\begin{array}{l}\text { Close-up photo of Los Medaños (M1/H1) } \\
\text { Mbr core, } 635.9-637.3 \mathrm{ft} \text { bgl, with } \\
\text { markings, scale, and time-date stamp }\end{array}$ & $\begin{array}{l}\text { DW Powers } \\
\text { Consultant to WTS }\end{array}$ \\
\hline SNL-12_Core158.jpg & 7-11-03 & $\begin{array}{l}\text { SNL-12 drillpad; } \\
\text { T23S, R31E, } \\
\text { sec20 }\end{array}$ & $\begin{array}{l}\text { Close-up photo of Los Medaños (M1/H1) } \\
\text { Mbr core, } 636.8 \text { - } 638.2 \mathrm{ft} \text { bgl, with } \\
\text { markings, scale, and time-date stamp }\end{array}$ & \begin{tabular}{|l} 
DW Powers \\
Consultant to WTS
\end{tabular} \\
\hline SNL-12_Core159.jpg & $7-11-03$ & $\begin{array}{l}\text { SNL-12 drillpad; } \\
\text { T23S, R31E, } \\
\text { sec20 }\end{array}$ & $\begin{array}{l}\text { Close-up photo of Los Medaños (M1/H1) } \\
\text { Mbr core, } 638.9-640.3 \mathrm{ft} \text { bgl, with } \\
\text { markings, scale, and time-date stamp }\end{array}$ & $\begin{array}{l}\text { DW Powers } \\
\text { Consultant to WTS }\end{array}$ \\
\hline SNL-12_Core160.jpg & $7-11-03$ & $\begin{array}{l}\text { SNL-12 drillpad; } \\
\text { T23S, R31E, } \\
\text { sec20 }\end{array}$ & $\begin{array}{l}\text { Close-up photo of Los Medaños (M1/H1) } \\
\text { Mbr core, } 639.9-641.3 \mathrm{ft} \text { bgl, with } \\
\text { markings, scale, and time-date stamp }\end{array}$ & $\begin{array}{l}\text { DW Powers } \\
\text { Consultant to WTS }\end{array}$ \\
\hline SNL-12_Core161.jpg & 7-11-03 & $\begin{array}{l}\text { SNL-12 drillpad; } \\
\text { T23S, R31E, } \\
\text { sec20 }\end{array}$ & $\begin{array}{l}\text { Close-up photo of Los Medaños (M1/H1) } \\
\text { Mbr core, } 640.8-642.2 \mathrm{ft} \text { bgl, with } \\
\text { markings, scale, and time-date stamp }\end{array}$ & $\begin{array}{l}\text { DW Powers } \\
\text { Consultant to WTS }\end{array}$ \\
\hline
\end{tabular}




\begin{tabular}{|c|c|c|c|c|}
\hline \multicolumn{5}{|c|}{ Photograph Log Sheet } \\
\hline File & DATE & LOCATION & $\begin{array}{l}\text { DESCRIPTION OF SUBJECT } \\
\text { (includes individual/group names, } \\
\text { direction, etc. as appropriate) }\end{array}$ & $\begin{array}{l}\text { PHOTOGRAPHER } \\
\text { (initials and dept.) }\end{array}$ \\
\hline SNL-12_Core162.jpg & 7-11-03 & $\begin{array}{l}\text { SNL-12 drillpad; } \\
\text { T23S, R31E, } \\
\text { sec20 }\end{array}$ & $\begin{array}{l}\text { Close-up photo of Los Medaños (M1/H1) } \\
\text { Mbr core, } 641.8-643.2 \mathrm{ft} \text { bgl, with } \\
\text { markings, scale, and time-date stamp }\end{array}$ & $\begin{array}{l}\text { DW Powers } \\
\text { Consultant to WTS }\end{array}$ \\
\hline SNL-12_Core163.jpg & $7-11-03$ & $\begin{array}{l}\text { SNL-12 drillpad; } \\
\text { T23S, R31E, } \\
\text { sec20 }\end{array}$ & $\begin{array}{l}\text { Close-up photo of Los Medaños (M1/H1) } \\
\text { Mbr core, } 642.8-644.2 \mathrm{ft} \text { bgl, with } \\
\text { markings, scale, and time-date stamp }\end{array}$ & $\begin{array}{l}\text { DW Powers } \\
\text { Consultant to WTS }\end{array}$ \\
\hline SNL-12_Core164.jpg & $7-11-03$ & $\begin{array}{l}\text { SNL-12 drillpad; } \\
\text { T23S, R31E, } \\
\text { sec20 }\end{array}$ & $\begin{array}{l}\text { Close-up photo of Los Medaños (M1/H1) } \\
\text { Mbr core, } 643.8-645.2 \mathrm{ft} \text { bgl, with } \\
\text { markings, scale, and time-date stamp }\end{array}$ & $\begin{array}{l}\text { DW Powers } \\
\text { Consultant to WTS }\end{array}$ \\
\hline SNL-12_Core165.jpg & 7-11-03 & $\begin{array}{l}\text { SNL-12 drillpad; } \\
\text { T23S, R31E, } \\
\text { sec20 }\end{array}$ & $\begin{array}{l}\text { Close-up photo of Los Medaños (M1/H1) } \\
\text { Mbr core, } 644.8-646.2 \mathrm{ft} \text { bgl, with } \\
\text { markings, scale, and time-date stamp }\end{array}$ & $\begin{array}{l}\text { DW Powers } \\
\text { Consultant to WTS }\end{array}$ \\
\hline SNL-12_Core166.jpg & 7-11-03 & $\begin{array}{l}\text { SNL-12 drillpad; } \\
\text { T23S, R31E, } \\
\text { sec20 }\end{array}$ & $\begin{array}{l}\text { Close-up photo of Los Medaños (M1/H1) } \\
\text { Mbr core, } 645.8-647.2 \mathrm{ft} \text { bgl, with } \\
\text { markings, scale, and time-date stamp }\end{array}$ & $\begin{array}{l}\text { DW Powers } \\
\text { Consultant to WTS }\end{array}$ \\
\hline SNL-12_Core167.jpg & 7-11-03 & $\begin{array}{l}\text { SNL-12 drillpad; } \\
\text { T23S, R31E, } \\
\text { sec20 }\end{array}$ & $\begin{array}{l}\text { Close-up photo of Los Medaños (M1/H1) } \\
\text { Mbr core, } 646.9-648.2 \mathrm{ft} \text { bgl, with } \\
\text { markings, scale, and time-date stamp }\end{array}$ & \begin{tabular}{|l} 
DW Powers \\
Consultant to WTS
\end{tabular} \\
\hline SNL-12_Core168.jpg & $7-11-03$ & $\begin{array}{l}\text { SNL-12 drillpad; } \\
\text { T23S, R31E, } \\
\text { sec20 }\end{array}$ & $\begin{array}{l}\text { Close-up photo of Los Medaños (M1/H1) } \\
\text { Mbr core, } 647.8 \text { - } 649.2 \mathrm{ft} \text { bgl, with } \\
\text { markings, scale, and time-date stamp }\end{array}$ & $\begin{array}{l}\text { DW Powers } \\
\text { Consultant to WTS }\end{array}$ \\
\hline SNL-12_Core169.jpg & 7-11-03 & $\begin{array}{l}\text { SNL-12 drillpad; } \\
\text { T23S, R31E, } \\
\text { sec20 }\end{array}$ & $\begin{array}{l}\text { Close-up photo of Los Medaños (M1/H1) } \\
\text { Mbr core, } 648.8-650.1 \mathrm{ft} \text { bgl, with } \\
\text { markings, scale, and time-date stamp }\end{array}$ & $\begin{array}{l}\text { DW Powers } \\
\text { Consultant to WTS }\end{array}$ \\
\hline SNL-12_Core170.jpg & 7-11-03 & $\begin{array}{l}\text { SNL-12 drillpad; } \\
\text { T23S, R31E, } \\
\text { sec20 }\end{array}$ & $\begin{array}{l}\text { Close-up photo of Los Medaños (M1/H1) } \\
\text { Mbr core, } 649.9-651.2 \mathrm{ft} \text { bgl, with } \\
\text { markings, scale, and time-date stamp }\end{array}$ & $\begin{array}{l}\text { DW Powers } \\
\text { Consultant to WTS }\end{array}$ \\
\hline SNL-12_Core171.jpg & $7-11-03$ & $\begin{array}{l}\text { SNL-12 drillpad; } \\
\text { T23S, R31E, } \\
\text { sec20 }\end{array}$ & $\begin{array}{l}\text { Close-up photo of Los Medaños (M1/H1) } \\
\text { Mbr core, } 650.9-652.2 \mathrm{ft} \text { bgl, with } \\
\text { markings, scale, and time-date stamp }\end{array}$ & $\begin{array}{l}\text { DW Powers } \\
\text { Consultant to WTS }\end{array}$ \\
\hline SNL-12_Core172.jpg & $7-11-03$ & $\begin{array}{l}\text { SNL-12 drillpad; } \\
\text { T23S, R31E, } \\
\text { sec20 }\end{array}$ & $\begin{array}{l}\text { Close-up photo of Los Medaños (M1/H1) } \\
\text { Mbr core, } 651.8 \text { - } 653.2 \mathrm{ft} \text { bgl, with } \\
\text { markings, scale, and time-date stamp }\end{array}$ & $\begin{array}{l}\text { DW Powers } \\
\text { Consultant to WTS }\end{array}$ \\
\hline SNL-12_Core173.jpg & 7-11-03 & $\begin{array}{l}\text { SNL-12 drillpad; } \\
\text { T23S, R31E, } \\
\text { sec20 }\end{array}$ & $\begin{array}{l}\text { Close-up photo of Los Medaños (M1/H1) } \\
\text { Mbr core, } 652.9 \text { - } 654.1 \mathrm{ft} \text { bgl, with } \\
\text { markings, scale, and time-date stamp }\end{array}$ & $\begin{array}{l}\text { DW Powers } \\
\text { Consultant to WTS }\end{array}$ \\
\hline SNL-12_Core174.jpg & 7-11-03 & $\begin{array}{l}\text { SNL-12 drillpad; } \\
\text { T23S, R31E, } \\
\text { sec20 }\end{array}$ & $\begin{array}{l}\text { Close-up photo of Los Medaños (M1/H1) } \\
\text { Mbr core, } 653.9-655.2 \mathrm{ft} \text { bgl, with } \\
\text { markings, scale, and time-date stamp }\end{array}$ & $\begin{array}{l}\text { DW Powers } \\
\text { Consultant to WTS }\end{array}$ \\
\hline SNL-12_Core175.jpg & $7-11-03$ & $\begin{array}{l}\text { SNL-12 drillpad; } \\
\text { T23S, R31E, } \\
\text { sec20 }\end{array}$ & $\begin{array}{l}\text { Close-up photo of Los Medaños (M1/H1) } \\
\text { Mbr core, } 654.9 \text { - } 656.1 \mathrm{ft} \text { bgl, with } \\
\text { markings, scale, and time-date stamp }\end{array}$ & $\begin{array}{l}\text { DW Powers } \\
\text { Consultant to WTS }\end{array}$ \\
\hline SNL-12_Core176.jpg & $7-11-03$ & $\begin{array}{l}\text { SNL-12 drillpad; } \\
\text { T23S, R31E, } \\
\text { sec20 }\end{array}$ & $\begin{array}{l}\text { Close-up photo of Los Medaños (M1/H1) } \\
\text { Mbr core, } 655.8 \text { - } 657.2 \mathrm{ft} \text { bgl, with } \\
\text { markings, scale, and time-date stamp }\end{array}$ & $\begin{array}{l}\text { DW Powers } \\
\text { Consultant to WTS }\end{array}$ \\
\hline
\end{tabular}




\begin{tabular}{|c|c|c|c|c|}
\hline \multicolumn{5}{|c|}{ Photograph Log Sheet } \\
\hline File & DATE & LOCATION & $\begin{array}{c}\text { DESCRIPTION OF SUBJECT } \\
\text { (includes individual/group names, } \\
\text { direction, etc. as appropriate) }\end{array}$ & $\begin{array}{l}\text { PHOTOGRAPHER } \\
\text { (initials and dept.) }\end{array}$ \\
\hline SNL-12_Core177.jpg & $7-11-03$ & $\begin{array}{l}\text { SNL-12 drillpad; } \\
\text { T23S, R31E; } \\
\text { sec20 }\end{array}$ & $\begin{array}{l}\text { Close-up photo of Los Medaños (M1/H1) } \\
\text { Mbr core, } 656.8 \text { - } 658.0 \mathrm{ft} \text { bgl, with } \\
\text { markings, scale, and time-date stamp }\end{array}$ & $\begin{array}{l}\text { DW Powers } \\
\text { Consultant to WTS }\end{array}$ \\
\hline SNL-12_Core178.jpg & $7-12-03$ & $\begin{array}{l}\text { SNL-12 drillpad; } \\
\text { T23S, R31E, } \\
\text { sec20 }\end{array}$ & $\begin{array}{l}\text { Close-up photo of Los Medaños (M1/H1) } \\
\text { Mbr core, } 672.9-674.2 \mathrm{ft} \text { bgl, with } \\
\text { markings, scale, and time-date stamp }\end{array}$ & $\begin{array}{l}\text { DW Powers } \\
\text { Consultant to WTS }\end{array}$ \\
\hline SNL-12_Core179.jpg & $7-12-03$ & $\begin{array}{l}\text { SNL-12 drillpad; } \\
\text { T23S, R31E, } \\
\text { sec20 }\end{array}$ & $\begin{array}{l}\text { Close-up photo of Los Medaños (M1/H1) } \\
\text { Mbr core, } 673.9-675.2 \mathrm{ft} \text { bgl, with } \\
\text { markings, scale, and time-date stamp }\end{array}$ & $\begin{array}{l}\text { DW Powers } \\
\text { Consultant to WTS }\end{array}$ \\
\hline SNL-12_Core180.jpg & $7-12-03$ & $\begin{array}{l}\text { SNL-12 drillpad; } \\
\text { T23S, R31E, } \\
\text { sec20 }\end{array}$ & $\begin{array}{l}\text { Close-up photo of Los Medaños (M1/H1) } \\
\text { Mbr core, } 674.8-676.1 \mathrm{ft} \text { bgl, with } \\
\text { markings, scale, and time-date stamp }\end{array}$ & $\begin{array}{l}\text { DW Powers } \\
\text { Consultant to WTS }\end{array}$ \\
\hline SNL-12_Core181.jpg & 7-12-03 & $\begin{array}{l}\text { SNL-12 drillpad; } \\
\text { T23S, R31E, } \\
\text { sec20 }\end{array}$ & $\begin{array}{l}\text { Close-up photo of Los Medaños (M1/H1) } \\
\text { Mbr core, } 675.9-677.1 \mathrm{ft} \text { bgl, with } \\
\text { markings, scale, and time-date stamp }\end{array}$ & $\begin{array}{l}\text { DW Powers } \\
\text { Consultant to WTS }\end{array}$ \\
\hline SNL-12_Core182.jpg & $7-12-03$ & $\begin{array}{l}\text { SNL-12 drillpad; } \\
\text { T23S, R31E, } \\
\text { sec20 }\end{array}$ & $\begin{array}{l}\text { Close-up photo of Los Medaños (M1/H1) } \\
\text { Mbr core, } 676.8-678.2 \mathrm{ft} \text { bgl, with } \\
\text { markings, scale, and time-date stamp }\end{array}$ & $\begin{array}{l}\text { DW Powers } \\
\text { Consultant to WTS }\end{array}$ \\
\hline SNL-12_Core183.jpg & $7-12-03$ & $\begin{array}{l}\text { SNL-12 drillpad; } \\
\text { T23S, R31E, } \\
\text { sec20 }\end{array}$ & $\begin{array}{l}\text { Close-up photo of Los Medaños (M1/H1) } \\
\text { Mbr core, } 677.8-679.2 \mathrm{ft} \text { bgl, with } \\
\text { markings, scale, and time-date stamp }\end{array}$ & $\begin{array}{l}\text { DW Powers } \\
\text { Consultant to WTS }\end{array}$ \\
\hline SNL-12_Core184.jpg & $7-12-03$ & $\begin{array}{l}\text { SNL-12 drillpad; } \\
\text { T23S, R31E, } \\
\text { sec20 }\end{array}$ & $\begin{array}{l}\text { Close-up photo of Los Medaños (M1/H1) } \\
\text { Mbr core, } 678.8-680.2 \mathrm{ft} \text { bgl, with } \\
\text { markings, scale, and time-date stamp }\end{array}$ & $\begin{array}{l}\text { DW Powers } \\
\text { Consultant to WTS }\end{array}$ \\
\hline SNL-12_Core185.jpg & $7-12-03$ & $\begin{array}{l}\text { SNL-12 drillpad; } \\
\text { T23S, R31E; } \\
\text { sec20 } \\
\end{array}$ & $\begin{array}{l}\text { Close-up photo of Los Medaños (M1/H1) } \\
\text { Mbr core, } 679.9-681.1 \mathrm{ft} \text { bgl, with } \\
\text { markings, scale, and time-date stamp }\end{array}$ & $\begin{array}{l}\text { DW Powers } \\
\text { Consultant to WTS }\end{array}$ \\
\hline SNL-12_Core186.jpg & $7-12-03$ & $\begin{array}{l}\text { SNL-12 drillpad; } \\
\text { T23S, R31E, } \\
\text { sec20 }\end{array}$ & $\begin{array}{l}\text { Close-up photo of Los Medaños (M1/H1) } \\
\text { Mbr core, } 680.8-682.1 \mathrm{ft} \text { bgl, with } \\
\text { markings, scale, and time-date stamp }\end{array}$ & $\begin{array}{l}\text { DW Powers } \\
\text { Consultant to WTS }\end{array}$ \\
\hline SNL-12_Core187.jpg & $7-12-03$ & $\begin{array}{l}\text { SNL-12 drillpad; } \\
\text { T23S, R31E, } \\
\text { sec20 }\end{array}$ & $\begin{array}{l}\text { Close-up photo of Los Medaños (M1/H1) } \\
\text { Mbr core, } 681.9-683.2 \mathrm{ft} \text { bgl, with } \\
\text { markings, scale, and time-date stamp }\end{array}$ & $\begin{array}{l}\text { DW Powers } \\
\text { Consultant to WTS }\end{array}$ \\
\hline SNL-12_Core188.jpg & 7-12-03 & $\begin{array}{l}\text { SNL-12 drillpad; } \\
\text { T23S, R31E, } \\
\text { sec20 } \\
\end{array}$ & $\begin{array}{l}\text { Close-up photo of Los Medaños (M1/H1) } \\
\text { Mbr core, } 682.9-684.1 \mathrm{ft} \text { bgl, with } \\
\text { markings, scale, and time-date stamp }\end{array}$ & $\begin{array}{l}\text { DW Powers } \\
\text { Consultant to WTS }\end{array}$ \\
\hline SNL-12_Core189.jpg & $7-12-03$ & $\begin{array}{l}\text { SNL-12 drillpad; } \\
\text { T23S, R31E, } \\
\text { sec20 }\end{array}$ & $\begin{array}{l}\text { Close-up photo of Los Medaños (M1/H1) } \\
\text { Mbr core, } 683.8-685.1 \mathrm{ft} \text { bgl, with } \\
\text { markings, scale, and time-date stamp }\end{array}$ & $\begin{array}{l}\text { DW Powers } \\
\text { Consultant to WTS }\end{array}$ \\
\hline SNL-12_Core190.jpg & $7-12-03$ & $\begin{array}{l}\text { SNL-12 drillpad; } \\
\text { T23S, R31E, } \\
\text { sec20 }\end{array}$ & $\begin{array}{l}\text { Close-up photo of Los Medaños (M1/H1) } \\
\text { Mbr core, } 684.8-686.1 \mathrm{ft} \text { bgl, with } \\
\text { markings, scale, and time-date stamp }\end{array}$ & $\begin{array}{l}\text { DW Powers } \\
\text { Consultant to WTS }\end{array}$ \\
\hline SNL-12_Core191.jpg & $7-12-03$ & $\begin{array}{l}\text { SNL-12 drillpad; } \\
\text { T23S, R31E, } \\
\text { sec20 } \\
\end{array}$ & $\begin{array}{l}\text { Close-up photo of Los Medaños (M1/H1) } \\
\text { Mbr core, } 685.8-687.2 \mathrm{ft} \text { bgl, with } \\
\text { markings, scale, and time-date stamp }\end{array}$ & $\begin{array}{l}\text { DW Powers } \\
\text { Consultant to WTS }\end{array}$ \\
\hline SNL-12_Core192.jpg & $7-12-03$ & $\begin{array}{l}\text { SNL-12 drillpad; } \\
\text { T23S, R31E, } \\
\text { sec20 }\end{array}$ & $\begin{array}{l}\text { Close-up photo of Los Medaños (M1/H1) } \\
\text { Mbr core, } 686.8-688.2 \mathrm{ft} \text { bgl, with } \\
\text { markings, scale, and time-date stamp }\end{array}$ & $\begin{array}{l}\text { DW Powers } \\
\text { Consultant to WTS }\end{array}$ \\
\hline
\end{tabular}




\begin{tabular}{|c|c|c|c|c|}
\hline \multicolumn{5}{|c|}{ Photograph Log Sheet } \\
\hline File & DATE & LOCATION & $\begin{array}{l}\text { DESCRIPTION OF SUBJECT } \\
\text { (includes individual/group names, } \\
\text { direction, etc. as appropriate) }\end{array}$ & $\begin{array}{c}\text { PHOTOGRAPHER } \\
\text { (initials and dept.) }\end{array}$ \\
\hline SNL-12_Core193.jpg & \begin{tabular}{|l|}
$7-12-03$ \\
\end{tabular} & $\begin{array}{l}\text { SNL-12 drillpad; } \\
\text { T23S, R31E, } \\
\text { sec20 }\end{array}$ & $\begin{array}{l}\text { Close-up photo of Los Medaños (M1/H1) } \\
\text { Mbr core, } 687.8-689.1 \mathrm{ft} \text { bgl, with } \\
\text { markings, scale, and time-date stamp }\end{array}$ & $\begin{array}{l}\text { DW Powers } \\
\text { Consultant to WTS }\end{array}$ \\
\hline SNL-12_Core194.jpg & $7-12-03$ & $\begin{array}{l}\text { SNL-12 drillpad; } \\
\text { T23S, R31E, } \\
\text { sec20 }\end{array}$ & $\begin{array}{l}\text { Close-up photo of Los Medaños (M1/H1) } \\
\text { Mbr core, } 688.8-690.1 \mathrm{ft} \text { bgl, with } \\
\text { markings, scale, and time-date stamp }\end{array}$ & $\begin{array}{l}\text { DW Powers } \\
\text { Consultant to WTS }\end{array}$ \\
\hline SNL-12_Core195.jpg & $7-12-03$ & $\begin{array}{l}\text { SNL-12 drillpad; } \\
\text { T23S, R31E, } \\
\text { sec20 }\end{array}$ & $\begin{array}{l}\text { Close-up photo of Los Medaños (M1/H1) } \\
\text { Mbr core, } 689.7-690.5 \mathrm{ft} \text { bgl, with } \\
\text { markings, scale, and time-date stamp }\end{array}$ & $\begin{array}{l}\text { DW Powers } \\
\text { Consultant to WTS }\end{array}$ \\
\hline SNL-12_Core196.jpg & \begin{tabular}{|l|}
$7-12-03$ \\
\end{tabular} & $\begin{array}{l}\text { SNL-12 drillpad; } \\
\text { T23S, R31E, } \\
\text { sec20 }\end{array}$ & $\begin{array}{l}\text { Close-up photo of Los Medaños (M1/H1) } \\
\text { Mbr core, } 689.9-691.2 \mathrm{ft} \text { bgl, with } \\
\text { markings, scale, and time-date stamp }\end{array}$ & $\begin{array}{l}\text { DW Powers } \\
\text { Consultant to WTS }\end{array}$ \\
\hline SNL-12_Core197.jpg & \begin{tabular}{|l|}
$7-12-03$ \\
\end{tabular} & $\begin{array}{l}\text { SNL-12 drillpad; } \\
\text { T23S, R31E, } \\
\text { sec20 }\end{array}$ & $\begin{array}{l}\text { Close-up photo of Los Medaños (M1/H1) } \\
\text { Mbr core, } 690.8-692.1 \mathrm{ft} \text { bgl, with } \\
\text { markings, scale, and time-date stamp }\end{array}$ & $\begin{array}{l}\text { DW Powers } \\
\text { Consultant to WTS }\end{array}$ \\
\hline SNL-12_Core198.jpg & $7-12-03$ & $\begin{array}{l}\text { SNL-12 drillpad; } \\
\text { T23S, R31E, } \\
\text { sec20 }\end{array}$ & $\begin{array}{l}\text { Close-up photo of Los Medaños (M1/H1) } \\
\text { Mbr and Salado Fm core, } 691.8-693.2 \mathrm{ft} \\
\text { bgl, with markings, scale, and time-date } \\
\text { stamp }\end{array}$ & $\begin{array}{l}\text { DW Powers } \\
\text { Consultant to WTS }\end{array}$ \\
\hline SNL-12_Core199.jpg & \begin{tabular}{|l|}
$77-12-03$ \\
\end{tabular} & $\begin{array}{l}\text { SNL-12 drillpad; } \\
\text { T23S, R31E, } \\
\text { sec20 }\end{array}$ & $\begin{array}{l}\text { Close-up photo of Salado Fm core, } 692.9 \\
694.2 \mathrm{ft} \text { bgl, with markings, scale, and } \\
\text { time-date stamp }\end{array}$ & $\begin{array}{l}\text { DW Powers } \\
\text { Consultant to WTS }\end{array}$ \\
\hline SNL-12_Core200.jpg & $7-12-03$ & $\begin{array}{l}\text { SNL-12 drillpad; } \\
\text { T23S, R31E, } \\
\text { sec20 }\end{array}$ & $\begin{array}{l}\text { Close-up photo of Salado Fm core, } 693.8 \\
695.2 \mathrm{ft} \text { bgl, with markings, scale, and } \\
\text { time-date stamp }\end{array}$ & $\begin{array}{l}\text { DW Powers } \\
\text { Consultant to WTS }\end{array}$ \\
\hline SNL-12_Core201.jpg & $7-12-03$ & $\begin{array}{l}\text { SNL-12 drillpad; } \\
\text { T23S, R31E, } \\
\text { sec20 }\end{array}$ & $\begin{array}{l}\text { Close-up photo of Salado Fm core, } 694.8 \\
696.1 \mathrm{ft} \text { bgl, with markings, scale, and } \\
\text { time-date stamp }\end{array}$ & \begin{tabular}{|l} 
DW Powers \\
Consultant to WTS
\end{tabular} \\
\hline SNL-12_Core202.jpg & $7-12-03$ & $\begin{array}{l}\text { SNL-12 drillpad; } \\
\text { T23S, R31E, } \\
\text { sec20 }\end{array}$ & $\begin{array}{l}\text { Close-up photo of Salado Fm core, } 695.8 \\
697.1 \mathrm{ft} \text { bgl, with markings, scale, and } \\
\text { time-date stamp }\end{array}$ & $\begin{array}{l}\text { DW Powers } \\
\text { Consultant to WTS }\end{array}$ \\
\hline SNL-12_Core203.jpg & $7-12-03$ & $\begin{array}{l}\text { SNL-12 drillpad; } \\
\text { T23S, R31E, } \\
\text { sec20 }\end{array}$ & $\begin{array}{l}\text { Close-up photo of Salado Fm core, } 696.8 \\
698.2 \mathrm{ft} \text { bgl, with markings, scale, and } \\
\text { time-date stamp }\end{array}$ & \begin{tabular}{|l|} 
DW Powers \\
Consultant to WTS
\end{tabular} \\
\hline SNL-12_Core204.jpg & $7-12-03$ & $\begin{array}{l}\text { SNL-12 drillpad; } \\
\text { T23S, R31E, } \\
\text { sec20 }\end{array}$ & $\begin{array}{l}\text { Close-up photo of Salado Fm core, } 697.8 \\
699.1 \mathrm{ft} \text { bgl, with markings, scale, and } \\
\text { time-date stamp }\end{array}$ & $\begin{array}{l}\text { DW Powers } \\
\text { Consultant to WTS }\end{array}$ \\
\hline SNL-12_Core205.jpg & 7-12-03 & $\begin{array}{l}\text { SNL-12 drillpad; } \\
\text { T23S, R31E, } \\
\text { sec20 }\end{array}$ & $\begin{array}{l}\text { Close-up photo of Salado Fm core, } 698.9 \\
700.2 \mathrm{ft} \text { bgl, with markings, scale, and } \\
\text { time-date stamp }\end{array}$ & $\begin{array}{l}\text { DW Powers } \\
\text { Consultant to WTS }\end{array}$ \\
\hline SNL-12_Core206.jpg & $7-12-03$ & $\begin{array}{l}\text { SNL-12 drillpad; } \\
\text { T23S, R31E, } \\
\text { sec20 }\end{array}$ & $\begin{array}{l}\text { Close-up photo of Salado Fm core, } 699.9 \\
701.2 \mathrm{ft} \text { bgl, with markings, scale, and } \\
\text { time-date stamp }\end{array}$ & \begin{tabular}{|l} 
DW Powers \\
Consultant to WTS
\end{tabular} \\
\hline SNL-12_Core207.jpg & \begin{tabular}{|l|}
$7-12-03$ \\
\end{tabular} & $\begin{array}{l}\text { SNL-12 drillpad; } \\
\text { T23S, R31E, } \\
\text { sec20 }\end{array}$ & $\begin{array}{l}\text { Close-up photo of Salado Fm core, } 700.9 \\
702.3 \mathrm{ft} \text { bgl, with markings, scale, and } \\
\text { time-date stamp }\end{array}$ & \begin{tabular}{|l} 
DW Powers \\
Consultant to WTS
\end{tabular} \\
\hline SNL-12_Core208.jpg & $7-12-03$ & $\begin{array}{l}\text { SNL-12 drillpad; } \\
\text { T23S, R31E, } \\
\text { sec20 }\end{array}$ & $\begin{array}{l}\text { Close-up photo of Salado Fm core, } 701.8 \\
703.2 \mathrm{ft} \text { bgl, with markings, scale, and } \\
\text { time-date stamp }\end{array}$ & $\begin{array}{l}\text { DW Powers } \\
\text { Consultant to WTS }\end{array}$ \\
\hline
\end{tabular}




\begin{tabular}{|c|c|c|c|c|}
\hline \multicolumn{5}{|c|}{ Photograph Log Sheet } \\
\hline File & DATE & LOCATION & $\begin{array}{l}\text { DESCRIPTION OF SUBJECT } \\
\text { (includes individual/group names, } \\
\text { direction, etc. as appropriate) }\end{array}$ & $\begin{array}{l}\text { PHOTOGRAPHER } \\
\text { (initials and dept.) }\end{array}$ \\
\hline SNL-12_Core209.jpg & $7-12-03$ & $\begin{array}{l}\text { SNL-12 drillpad; } \\
\text { T23S, R31E, } \\
\text { sec20 }\end{array}$ & $\begin{array}{l}\text { Close-up photo of Salado Fm core, } 702.8 \\
704.2 \mathrm{ft} \text { bgl, with markings, scale, and } \\
\text { time-date stamp }\end{array}$ & $\begin{array}{l}\text { DW Powers } \\
\text { Consultant to WTS }\end{array}$ \\
\hline SNL-12_Core210.jpg & 7-12-03 & $\begin{array}{l}\text { SNL-12 drillpad; } \\
\text { T23S, R31E, } \\
\text { sec20 }\end{array}$ & $\begin{array}{l}\text { Close-up photo of Salado Fm core, } 703.8 \\
705.2 \mathrm{ft} \text { bgl, with markings, scale, and } \\
\text { time-date stamp }\end{array}$ & $\begin{array}{l}\text { DW Powers } \\
\text { Consultant to WTS }\end{array}$ \\
\hline SNL-12_Core211.jpg & 7-12-03 & $\begin{array}{l}\text { SNL-12 drillpad; } \\
\text { T23S, R31E, } \\
\text { sec20 }\end{array}$ & $\begin{array}{l}\text { Close-up photo of Salado Fm core, } 704.8 \\
706.3 \mathrm{ft} \text { bgl, with markings, scale, and } \\
\text { time-date stamp }\end{array}$ & $\begin{array}{l}\text { DW Powers } \\
\text { Consultant to WTS }\end{array}$ \\
\hline SNL-12_Core212.jpg & $7-12-03$ & $\begin{array}{l}\text { SNL-12 drillpad; } \\
\text { T23S, R31E, } \\
\text { sec20 }\end{array}$ & $\begin{array}{l}\text { Close-up photo of Salado Fm core, } 705.8 \\
707.2 \mathrm{ft} \text { bgl, with markings, scale, and } \\
\text { time-date stamp }\end{array}$ & $\begin{array}{l}\text { DW Powers } \\
\text { Consultant to WTS }\end{array}$ \\
\hline SNL-12_Core213.jpg & 7-12-03 & $\begin{array}{l}\text { SNL-12 drillpad; } \\
\text { T23S, R31E, } \\
\text { sec20 }\end{array}$ & $\begin{array}{l}\text { Close-up photo of Salado Fm core, } 706.8 \\
708.2 \mathrm{ft} \text { bgl, with markings, scale, and } \\
\text { time-date stamp }\end{array}$ & $\begin{array}{l}\text { DW Powers } \\
\text { Consultant to WTS }\end{array}$ \\
\hline SNL-12_Core214.jpg & 7-12-03 & $\begin{array}{l}\text { SNL-12 drillpad; } \\
\text { T23S, R31E, } \\
\text { sec20 }\end{array}$ & $\begin{array}{l}\text { Close-up photo of Salado Fm core, } 707.9 \\
709.3 \mathrm{ft} \text { bgl, with markings, scale, and } \\
\text { time-date stamp }\end{array}$ & $\begin{array}{l}\text { DW Powers } \\
\text { Consultant to WTS }\end{array}$ \\
\hline SNL-12_Core215.jpg & $7-12-03$ & $\begin{array}{l}\text { SNL-12 drillpad; } \\
\text { T23S, R31E, } \\
\text { sec20 }\end{array}$ & $\begin{array}{l}\text { Close-up photo of Salado Fm core, } 708.8 \\
710.2 \mathrm{ft} \text { bgl, with markings, scale, and } \\
\text { time-date stamp }\end{array}$ & $\begin{array}{l}\text { DW Powers } \\
\text { Consultant to WTS }\end{array}$ \\
\hline SNL-12_Core216.jpg & $7-12-03$ & $\begin{array}{l}\text { SNL-12 drillpad; } \\
\text { T23S, R31E, } \\
\text { sec20 }\end{array}$ & $\begin{array}{l}\text { Close-up photo of Salado Fm core, } 709.8 \\
711.2 \mathrm{ft} \text { bgl, with markings, scale, and } \\
\text { time-date stamp }\end{array}$ & $\begin{array}{l}\text { DW Powers } \\
\text { Consultant to WTS }\end{array}$ \\
\hline SNL-12_Core217.jpg & 7-12-03 & $\begin{array}{l}\text { SNL-12 drillpad; } \\
\text { T23S, R31E, } \\
\text { sec20 }\end{array}$ & $\begin{array}{l}\text { Close-up photo of Salado Fm core, } 710.8 \\
712.2 \mathrm{ft} \text { bgl, with markings, scale, and } \\
\text { time-date stamp }\end{array}$ & $\begin{array}{l}\text { DW Powers } \\
\text { Consultant to WTS }\end{array}$ \\
\hline SNL-12_Core218.jpg & $7-12-03$ & $\begin{array}{l}\text { SNL-12 drillpad; } \\
\text { T23S, R31E, } \\
\text { sec20 }\end{array}$ & $\begin{array}{l}\text { Close-up photo of Salado Fm core, } 711.9 \\
713.2 \mathrm{ft} \text { bgl, with markings, scale, and } \\
\text { time-date stamp }\end{array}$ & $\begin{array}{l}\text { DW Powers } \\
\text { Consultant to WTS }\end{array}$ \\
\hline SNL-12_Core219.jpg & $7-12-03$ & $\begin{array}{l}\text { SNL-12 drillpad; } \\
\text { T23S, R31E, } \\
\text { sec20 }\end{array}$ & $\begin{array}{l}\text { Close-up photo of Salado Fm core, } 712.8 \\
714.2 \mathrm{ft} \text { bgl, with markings, scale, and } \\
\text { time-date stamp }\end{array}$ & $\begin{array}{l}\text { DW Powers } \\
\text { Consultant to WTS }\end{array}$ \\
\hline SNL-12_Core220.jpg & 7-12-03 & $\begin{array}{l}\text { SNL-12 drillpad; } \\
\text { T23S, R31E, } \\
\text { sec20 }\end{array}$ & $\begin{array}{l}\text { Close-up photo of Salado Fm core, } 713.8 \\
715.1 \mathrm{ft} \text { bgl, with markings, scale, and } \\
\text { time-date stamp }\end{array}$ & $\begin{array}{l}\text { DW Powers } \\
\text { Consultant to WTS }\end{array}$ \\
\hline SNL-12_Core221.jpg & 7-12-03 & $\begin{array}{l}\text { SNL-12 drillpad; } \\
\text { T23S, R31E, } \\
\text { sec20 }\end{array}$ & $\begin{array}{l}\text { Close-up photo of Salado Fm core, } 714.9 \\
716.1 \mathrm{ft} \text { bgl, with markings, scale, and } \\
\text { time-date stamp }\end{array}$ & $\begin{array}{l}\text { DW Powers } \\
\text { Consultant to WTS }\end{array}$ \\
\hline
\end{tabular}




\begin{tabular}{|c|c|c|c|c|}
\hline \multicolumn{5}{|c|}{ Photograph Log Sheet } \\
\hline File & DATE & LOCATION & $\begin{array}{l}\text { DESCRIPTION OF SUBJECT } \\
\text { (includes individual/group names, } \\
\text { direction, etc. as appropriate) }\end{array}$ & $\begin{array}{l}\text { PHOTOGRAPHER } \\
\text { (initials and dept.) }\end{array}$ \\
\hline SNL-12_Core222.jpg & $7-12-03$ & $\begin{array}{l}\text { SNL-12 drillpad; } \\
\text { T23S, R31E, } \\
\text { sec20 }\end{array}$ & $\begin{array}{l}\text { Close-up photo of Salado Fm core, } 715.8 \\
717.1 \mathrm{ft} \text { bgl, with markings, scale, and } \\
\text { time-date stamp }\end{array}$ & $\begin{array}{l}\text { DW Powers } \\
\text { Consultant to WTS }\end{array}$ \\
\hline SNL-12_Core223.jpg & $7-12-03$ & $\begin{array}{l}\text { SNL-12 drillpad; } \\
\text { T23S, R31E, } \\
\text { sec20 }\end{array}$ & $\begin{array}{l}\text { Close-up photo of Salado Fm core, } 716.9 \\
718.2 \mathrm{ft} \text { bgl, with markings, scale, and } \\
\text { time-date stamp }\end{array}$ & $\begin{array}{l}\text { DW Powers } \\
\text { Consultant to WTS }\end{array}$ \\
\hline SNL-12_Core224.jpg & $7-12-03$ & $\begin{array}{l}\text { SNL-12 drillpad; } \\
\text { T23S, R31E, } \\
\text { sec20 }\end{array}$ & $\begin{array}{l}\text { Close-up photo of Salado Fm core, } 717.8 \\
719.2 \mathrm{ft} \text { bgl, with markings, scale, and } \\
\text { time-date stamp }\end{array}$ & $\begin{array}{l}\text { DW Powers } \\
\text { Consultant to WTS }\end{array}$ \\
\hline SNL-12_Core225.jpg & $7-12-03$ & $\begin{array}{l}\text { SNL-12 drillpad; } \\
\text { T23S, R31E, } \\
\text { sec20 }\end{array}$ & $\begin{array}{l}\text { Close-up photo of Salado Fm core, } 718.9 \\
720.2 \mathrm{ft} \text { bgl, with markings, scale, and } \\
\text { time-date stamp }\end{array}$ & $\begin{array}{l}\text { DW Powers } \\
\text { Consultant to WTS }\end{array}$ \\
\hline SNL-12_Core226.jpg & 7-12-03 & $\begin{array}{l}\text { SNL-12 drillpad; } \\
\text { T23S, R31E, } \\
\text { sec20 }\end{array}$ & $\begin{array}{l}\text { Close-up photo of Salado Fm core, } 719.7 \\
720.6 \mathrm{ft} \text { bgl, with markings, scale, and } \\
\text { time-date stamp }\end{array}$ & $\begin{array}{l}\text { DW Powers } \\
\text { Consultant to WTS }\end{array}$ \\
\hline
\end{tabular}

